THIAGO JOSÉ DA SILVA

\title{
LIMITES À VINCULAÇÃO DE ADMINISTRADORES A ACORDo De ACIONISTAS
}

Faculdade de Direito da Universidade de São Paulo

São Paulo

2014 
THIAGO JOSÉ DA SILVA

\title{
LIMITES À VINCULAÇÃO DE ADMINISTRADORES A ACORDO DE ACIONISTAS
}

\author{
Dissertação apresentada como requisito parcial \\ para a obtenção do título de Mestre em Direito \\ Comercial pela Faculdade de Direito da \\ Universidade de São Paulo. \\ Orientador: Professor Doutor Haroldo \\ Malheiros Duclerc Verçosa
}

Faculdade de Direito da Universidade de São Paulo

São Paulo

2014

Nome: JOSÉ DA SILVA, Thiago

Título: Limites à Vinculação de Administradores a Acordo de Acionistas 
Dissertação apresentada como requisito parcial para a obtenção do título de Mestre em Direito Comercial pela Faculdade de Direito da Universidade de São Paulo.

Orientador: Professor Doutor Haroldo Malheiros Duclerc Verçosa

Aprovado em:

\section{BANCA EXAMINADORA}

Prof. (a)

Julgamento:

Instituição:

Assinatura:

Prof. (a)

Julgamento:

Instituição:

Assinatura:

Prof. (a)

Instituição:

Julgamento:

Assinatura: 


\section{AGRADECIMENTOS}

Agradeço ao Professor Haroldo Malheiros Duclerc Verçosa, pela oportunidade de vida e aprendizado concedida, bem como a paciência e a objetividade com que orientou meus estudos durante o Mestrado.

Agradeço aos meus pais amados, Osório e Roberta, pelo amor, dedicação e crença incondicionais.

Agradeço à Natália, pela delicadeza e parceria dedicadas a este momento tão especial de nossas vidas.

Agradeço ao amigo e mentor Evandro, por ter sido o primeiro a vislumbrar e, até hoje, incentivar esse caminho.

Agradeço ao Pinheiro Neto Advogados, pelo suporte institucional, farta biblioteca e por me permitir ricas experiências profissionais diárias que tanto contribuíram para a elaboração deste trabalho.

Agradeço, por fim, ao João Marcelo, pelas lições diárias de precisão e eficiência. 


\section{RESUMO}

Esta dissertação analisa os limites e a conveniência da vinculação de administradores a acordo de acionistas. Com a promulgação da lei $\mathrm{n}^{\circ} 10.303$, de 31 de outubro de 2001, foram incluídos os $\S \S 8^{\circ}$ e $9^{\circ}$, ao art. 118 da lei $n^{\circ}$ 6.404, de 15 de dezembro de 1976 (LSA), que indisputavelmente passaram a vincular os administradores de companhias aos termos dos acordos de acionistas arquivados em suas sedes. Desde então, inexiste consenso doutrinário e jurisprudencial acerca dos limites de tal vinculação. A dissertação analisa, pois, as principais posições doutrinárias que variam desde a vinculação genérica, até a vinculação relativa. A primeira é capaz de abranger todos os atos da administração; a segunda, por sua vez, limita a possibilidade de vinculação da administração apenas com relação aos atos que não sejam de sua competência privativa previstos em lei ou pelo estatuto e, ainda, preserva o poder (dever) finalístico do administrador, previsto no art. 154 da LSA, de buscar e privilegiar o interesse da companhia. A dissertação tece, ainda, diversos cometários e posicionamentos sobre a conveniência de se vincular administradores.

PALAVRAS-CHAVE: Acordo de Acionistas; Deveres Fiduciários de Administradores; Interesse Social; Soberania da Assembleia Geral de Acionistas; Princípio da Indelegabilidade; Vinculação de Administradores; Grupos Societários. 


\begin{abstract}
This dissertation analyses the limits and the convenience of binding administrators to the shareholders' agreement. With the promulgation of law $\mathrm{n}^{\circ} 10,303$, of October 31,2001 , $\S \S 8^{\circ}$ and $9^{\circ}$ were included to the article 118 of law $n^{\circ} 6,404$, of December 15, 1976 (LSA), which indisputably began to bind companies' administrators to the terms of the shareholder agreements filed in their headquarters. Since then, there is no consensus in the doctrine or the precedents about the limits of such binding situation. The dissertation analyses, thus, the main doctrinal positions ranging from the generic binding form until the relative one. The first is able to cover all acts of the administration; the second, on it turn, limits the possibility of binding the administration only with respect to acts that are not part of its competence provided for by law or by companies' by-laws, and also preserves the finalistic power (duty) of the administrator provided for in article 154 of the LSA, of pursuing and giving priority to the companies interest. The dissertation also weaves several comentaries and positions on the desirability to bind administrators.
\end{abstract}

KEYWORDS: Shareholders' Agreement; Administrators' Fiduciary Duties; Companies' Interest; Sovereignty of the General Meeting of Shareholders; Principle of NonDelegation; Binding of Adminstrators; Corporate Groups. 


\section{LISTA DE ABREVIATURAS E SIGLAS}

$\begin{array}{ll}\text { BM\&FBovespa } & \begin{array}{l}\text { BM\&FBovespa S.A. - Bolsa de Valores, Mercadorias } \\ \text { e Futuros }\end{array} \\ \text { CVM } & \text { Comissão de Valores Mobiliários } \\ \text { CAF } & \text { Comitê de Fusões e Aquisições } \\ \text { DNRC } & \text { Departamento Nacional do Registro de Comércio } \\ \text { IBGC } & \text { Instituto Brasileiro de Governança Corporativa } \\ \text { LSA } & \text { Lei n }{ }^{\circ} 6.404, \text { de } 15 \text { de dezembo de } 1976 \\ \text { PND } & \text { Segundo Plano Nacional de Desenvolvimento }\end{array}$




\section{SUMÁRIO}

$\begin{array}{lll}\text { I Introdução } & \mathbf{1 0}\end{array}$

$\begin{array}{ll}\text { 1.1. Objeto } & 10\end{array}$

\begin{tabular}{ll} 
1.2. & Estrutura da dissertação \\
\hline
\end{tabular}

$\begin{array}{ll}\text { II Notas sobre a sociedade anônima } & 13\end{array}$

2.1. Histórico da sociedade anônima no Direito Comparado 13

$\begin{array}{lll}\text { 2.2. Histórico da sociedade anônima no Brasil } & 14\end{array}$

$\begin{array}{ll}\text { 2.2.1. Antecedentes da LSA } & 15\end{array}$

$\begin{array}{lll}\text { 2.2.2. A LSA } & 17\end{array}$

$\begin{array}{ll}\text { 2.3. Natureza jurídica da sociedade anônima } & 18\end{array}$

2.4. Estrutura de propriedade da sociedade anônima. Crítica à LSA 20

2.5. Estrutura administrativa da sociedade anônima. A teoria organicista 25

2.5.1. Histórico da estrutura administrativa 27

2.5.2. A teoria organicista 28

2.5.3. Hierarquia entre órgãos 30

$\begin{array}{ll}\text { III } O \text { interesse social } & 34\end{array}$

3.1. Teorias contratualistas 34

3.1.1. Escola clássica 35

3.1.2. Escolas modernas: o shareholder primacy 37

3.1.3. Crítica ao shareholder primacy 40

3.2. Teorias institucionalistas 41

$\begin{array}{lll}\text { 3.2.1. Escolas clássicas } & 41\end{array}$

3.2.2. Escola moderna e doutrina brasileira 45

3.3. Análise econômica do direito e a teoria do contrato-organização 48 
3.3.1. Crítica à análise econômica e ao contrato-organização

3.4. Nossa visão

3.4.1. Conclusão prática $\quad 52$

3.4.2. Conclusão ideológica $\quad 57$

IV O poder do acionista em foco $\quad 60$

4.1. O acordo de acionistas 61

4.1.1. Conceito, histórico e panorama 61

$\begin{array}{lll}\text { 4.1.2. } & \text { Objeto } & 65\end{array}$

4.1.2.1. Acordo de controle 66

4.1.2.2. Acordo de minoria $\quad 69$

$\begin{array}{lll}\text { 4.1.3. } & \text { Natureza jurídica } & 71\end{array}$

$\begin{array}{lll}\text { 4.1.4. Notas sobre Direito Comparado } & 73\end{array}$

$\begin{array}{lll}\text { 4.2. Soberania da assembleia geral de acionistas } & 74\end{array}$

$\begin{array}{lll}\text { V O poder da administração em foco } & 79\end{array}$

5.1. Deveres fiduciários da administração 81

5.2. Competência privativa e o princípio da indelegabilidade 86

5.3. Independência de conselheiros, as boas práticas de governança, 91 conselheiros independentes e o papel da autorregulação

5.3.1. Independência de conselheiros 92

5.3.2. As boas práticas de governança corporativa, os conselheiros 93 independentes e o papel da autorregulação

VI Vinculação da administração ao acordo de acionistas. Posições 102 doutrinárias e autorregulação

$\begin{array}{ll}\text { 6.1. Vinculação genérica } & 103\end{array}$

$\begin{array}{ll}\text { 6.2. Vinculação relativa } & 104\end{array}$ 
6.3. Impossibilidade de vinculação e o papel da autorregulação

6.4. Análise empírica de Gorga e Gelman

VII Vinculação da administração ao acordo de acionistas. 114

Precedentes

$\begin{array}{lll}\text { 7.1. } & \text { Esfera judicial } & 114\end{array}$

$\begin{array}{ll}\text { 7.2. } & 115\end{array}$

VIII Vinculação da administração no Direito Comparado 116

IX Vinculação da administração nos grupos societários de fato e de 119 direito

$\begin{array}{llr}\text { X Nossa visão e conclusões } & 123\end{array}$

$\begin{array}{lll}\text { 10.1. Conclusão prática } & 123\end{array}$

$\begin{array}{lll}\text { 10.2. Conclusão ideológica } & 125\end{array}$

$\begin{array}{lll}\text { XI Bibliografia } & 127\end{array}$ 


\section{INTRODUÇÃO}

\subsection{Objeto}

Até a promulgação da lei $n^{\circ} 10.303$, de 31 de outubro de 2001, muito se discutia acerca da conveniência ou não de, numa visão geral, se vincular administradores a acordos de acionistas. Depois da referida lei, porém, a vinculação foi confirmada e se tornou uma realidade inegável.

Passaram a ser debatidos, desde então, sem o substacial consenso jurisprudencial e doutrinário que o tema merece, especialmente em virtude das cada vez mais frequentes discussões sobre adoção de melhores práticas de governança corporativa: (i) se o legislador agiu corretamente, e (ii) os limites de tal vinculação frente a outros dispositivos da LSA.

O fato é que, embora a alteração da LSA em 2001 tenha deixado claro que o acordo de acionistas é capaz de vincular os administradores, não tratou, tampouco harmonizou com os demais dispositivos da lei, aquilo que pode ser efetivamente vinculante à administração.

Com isso, a controvérsia deste tema reside no potencial entrechoque de alguns dispositivos da LSA tratados ao longo da dissertação. De um lado, o art. 118, caput (acordo de controle) e $\$ \S 8^{\circ}$ e $9^{\circ}$ (vinculação) e o art. 121 (soberania da assembleia geral). De outro, o art. 154, caput e $\S 1^{\circ}$ (poder-dever do administrador de observância do interesse social), art. 139 (princípio da indelegabilidade de funções) e arts. 142 e 144 (matérias de competência do conselho de administração e da diretoria).

Em outras palavras, existe um potencial conflito entre os dispositivos acima: enquanto certas matérias são de competência da administração, e não poderiam ser delegadas a outro órgão societário, a assembleia geral possui poderes para decidir todos os assuntos relativos ao objeto da companhia e o acordo de acionistas passou a vincular os administradores. 
Identificamos, claramente, a intenção do legislador de vincular os membros de órgãos colegiados (o conselho de administração ou, na ausência deste, a diretoria e desde que esta tenha caráter deliberativo) aos termos do acordo de acionistas, na medida em que confere ao presidente da reunião o dever de não computar o voto em desacordo com o pacto, bem como possibilita que a parte prejudicada pela ausência ou abstenção à reunião do membro da administração vote por tal membro eleito com seu voto.

Notamos, também, com alguma clareza, o dever dos administradores de tomar suas decisões (i) de forma diligente, (ii) em conformidade com a finalidade de suas atribuições e (iii) em atenção ao interesse social e o bem público, independentemente das instruções que porventura possam receber dos acionistas que os elegeram.

Trata-se de um tema que, em nossa visão, merecia mais clareza, a fim de garantir segurança a todos os envolvidos. 


\subsection{Estrutura desta dissertação}

Iniciaremos a dissertação pela apresentação, no Capítulo II, do objeto nuclear de estudo, qual seja, a sociedade anônima. Discorreremos brevemente sobre seu histórico no Direito Comparado e no Brasil, com enfoque especial à LSA.

A tão elogiada lei, neste trabalho, é objeto de controvérsias, em razão de potenciais disposições contraditórias (i.e., art. 118 versus arts. 154 e 139) e de críticas construtivas sobre sua evolução e necessidade de eficiente e eficazmente regular tanto estruturas de propriedade concentradas, quanto dispersas.

Na sequência, será apresentada a estrutura administrativa da sociedade anônima, ocasião em que visitaremos a teoria orgânica que representa delimitador chave do tema desta dissertação.

Adentraremos, então, no Capítulo III, destinado a tratar de outro tema chave, o conceito de interesse social. De sua definição, dependerão outras respostas sobre consideração ou não, pelo acionista controlador e pela administração, de interesses outros além daqueles dos sócios.

Depois de localizado o objeto de estudo, utilizaremos os Capítulos IV e V para apresentar as fontes de poder da sociedade anônima. Afinal, saber se e quanto uma delas (administração) pode ser vinculada por outra (acionistas) exige um prévio e intenso estudo de como se organizam e a quais deveres estão sujeitos.

Do Capítulo VI ao IX trataremos da vinculação da administração em si, passando pelas principais e diversas posições doutrinárias, precedentes judiciais, estudo de Direito Comparado e breves notas sobre o tema no âmbito dos grupos societários.

Por fim, o Capítulo $\mathrm{X}$ reserva nossa visão sobre o tema em questão e diversos outros assuntos correlatos discutidos ao longo do trabalho. 


\section{NOTAS SOBRE A SOCIEDADE ANÔNIMA}

Como já dizia VIVANTE ${ }^{1}$, “(...) ninguém deve se aventurar em discussões jurídicas se não conhece a fundo a estrutura técnica e a função econômica do tema objeto de estudo."

Assim, antes de adentrar no estudo da estrutura da sociedade anônima, suas fontes de poder e possibilidade de vinculação da administração por acordo de acionistas, voltaremos um passo para analisar a sociedade anônima em si, um pouco de seu histórico no Direito Comparado, no Brasil, bem como dos princípios que norteiam a LSA.

Assim, ainda que a sociedade anônima (em si considerada) não seja o tema central deste trabalho, tampouco tenhamos a pretensão de transmitir profundo conhecimento técnico e econômico de tal instituto, sua análise prévia organizará a leitura e entendimento do leitor dos capítulos seguintes.

Em poucas palavras, definiríamos a sociedade anônima como o instrumento jurídico de organização da empresa ${ }^{2}$.

\subsection{Histórico da sociedade anônima no Direito Comparado}

Segundo VERÇOSA, "[d]e forma esquemática, pode-se concluir que a história da constituição das sociedades anônimas passou por três grandes períodos: privilégio, autorização e liberdade" 3 .

\footnotetext{
${ }^{1}$ VIVANTE, Cesare. Trattado di Diritto Comerciale, $5^{\circ}$ ed., Milão, Dottore Francesco Vallardi, 1922, pp. IX-X, apud, VERGUEIRO, Carlos Eduardo. Acordo de Acionistas e a Governança das Companhias. São Paulo: Quartier Latin, 2010, p. 29.

${ }^{2}$ (i) Analisada sob o perfil funcional (atividade empresarial) a partir da clássica lição de AsQUINI (ASQUINI, Alberto. Perfis da Empresa. Tradução e notas de Fábio Konder Comparato. In Revista de Direito Mercantil, Industrial, Econômico e Financeiro. no 104. São Paulo: Malheiros, 1996, pp. 103 a 126; (ii) MuNHOZ, por sua vez, define a sociedade por ações como "técnica jurídica de organização, cuja finalidade é permitir a acumulação de capital necessária ao desenvolvimento da atividade empresarial no sistema capitalista." (MUNHOZ, Eduardo Secchi. Empresa contemporânea e direito societário - poder de controle e grupos de sociedades. São Paulo: Juarez de Oliveira, 2002, p. 25).

${ }^{3}$ VERÇOSA, Haroldo Malheiros Duclerc. Curso de direito comercial. v. 2. $2^{\mathrm{a}}$ ed. São Paulo: Malheiros, 2010, p. 60 .
} 
Na primeira fase (de privilégio), a sociedade anônima consistia em um instrumento de atividade estatal ${ }^{4}$. Essa era a característica da primeira sociedade anônima que se tem notícia, qual seja, a Companhia das Índias Orientais, fundada na Holanda, em $1602^{5}$.

Segundo VERÇOSA, diversos institutos da sociedade anônima hoje concebidos já estavam presentes na Companhia das Índicas Orientais, especialmente a responsabilidade limitada ao valor do capital subscrito, livre negociação dos títulos representativos do capital e direito a dividendos periódicos ${ }^{6}$.

Do ponto de vista regulatório, o Código Comercial francês de 1807 foi o primeiro diploma a regulamentar a sociedade anônima, naquele momento ainda sujeita à prévia autorização governamental ${ }^{7}$.

Depois disso, uma segunda fase (autorização), a sociedade anônima ingressou no direito privado com a Revolução Francesa, em 1889. Passou-se a permitir a prática do livre comércio a partir de sua fase intermediária de autorização que, nas palavras de VERÇOSA, "hoje se mantém apenas para setores específicos da economia, tais como bancos, seguradoras etc".

\subsection{Histórico da sociedade anônima no Brasil}

\footnotetext{
4 “(...) deve-se não perder de vista que as primeiras companhias, a partir das holandesas, exerciam atividades próprias do Estado, entre as quais - principalmente - a conquista e a colonização de novas terras, sendo-lhes permitidas a organização e manutenção de exércitos e fortificações militares." (VERÇOSA, Haroldo Malheiros Duclerc. Curso de direito comercial. v. 3. $2^{\mathrm{a}}$ ed. São Paulo: Malheiros, 2011, p. 53).

5 “"O modelo (...) somente surgiu efetivamente com tais características no início do século XVII, tendo sido a Companhia das Índias Orientais, fundada na Holanda em 1602, a primeira sociedade anônima, a cuja evolução se deu sequência ao longo do tempo sem perda da linha do seu desenvolvimento." (VERÇOSA, Haroldo Malheiros Duclerc. Curso de direito comercial. v. 3. $2^{\text {a }}$ ed. São Paulo: Malheiros, 2011, p. 50)

6 “'A responsabilidade dos 'acionistas' estava limitada ao montante subscrito, desenvolvendo-se um mercado onde passaram a ser negociadas. Tal mercado era formado fundalmentalmente pela Bolsa de Amsterdã, à qual se agregou o Banco de Amsterdã, com função complementar à atividade daquela companhia. (...) "Uma visão capitalista precoce já estava presente em tais sociedades, em função das seguintes características: (i) livre negociação dos títulos formadores do seu capital; (ii) ausência de qualquer preconceito de raça, nacionalidade ou religião quanto às pessoas dos acionistas; (iii) limitação da responsabilidade ao montante das ações subscritas ou adquiridas; (iv) caráter de títulos de crédito quanto às ações; (v) direito dos acionistas ao recebimento de dividendos periódicos; (vi) reunião dos acionistas para a eleição dos diretores e para a tomada de contas destes por meio de um conselho fiscal." (VERÇOSA, Haroldo Malheiros Duclerc. Curso de direito comercial. v. 3. $2^{\text {a }}$ ed. São Paulo: Malheiros, 2011, p. 55)

7 "Foi o Código Comercial francês de 1807 (CCoF) o primeiro diploma legislativo a recepcionar as sociedades anônimas, sujeitas em sua criação à autorização governamental, em vista do receio de que pudessem causar prejuízos aos próprios acionistas, ao crédito em geral e ao público. (...) naquela época, tais sociedades podiam ser civis ou comerciais, possibilidade desaparecida no futuro, quando tais institutos passaram a ser destinados exclusivamente à atividade mercantil" (VERÇOSA, Haroldo Malheiros Duclerc. Curso de direito comercial. v. 3. $2^{\mathrm{a}}$ ed. São Paulo: Malheiros, 2011, pp. 55-56)
} 


\subsubsection{Antecedentes da LSA}

Anteriormente à promulgação da LSA, o Código Comercial Brasileiro, de 1850, foi o primeiro diploma brasileiro a tratar da sociedade anônima. Sua constituição deveria ser feita necessariamente por prazo determinado e mediante autorização estatal ${ }^{8}$.

O segundo momento de evolução da sociedade anônima no Brasil passou pela promulgação dos Decretos 434, de $1891^{9}$ e 2.627 , de 1940 , este baseado no projeto de Trajano Miranda Valverde, e perdurou até a edição da LSA.

Importantes leis antecederam a LSA, notadamente as leis 4.595, de 31 de dezembro de 1964 (lei de reforma bancária) e 4.728, de 14 de julho de 1965 (lei do mercado de capitais). Porém, em vista das crises verificadas em tal período, o mercado (tanto

\footnotetext{
8."Apenas cinco artigos foram dispensados pelo CCoB [Código Comercial Brasileiro] ao regramento das sociedades anônimas, cujo paradigma imediato foi o Código Comercial de Portugal (CCoP), por sua vez inspirado na matriz francesa. (...) O CCoB, por sua vez, ao voltar-se para esse instituto (...) adotou-o com as seguintes características: (i) chamadas de 'companhias' ou de 'sociedades anônima', seriam designadas pelo objeto ou empresa (atividade) a que se destinassem. (ii) não possuíam firma social. (iii) os administradores, sócios ou não, exerciam mandatos revogáveis. (iv) sua constituição era feita obrigatoriamente por prazo determinado, mediante autorização do Governo, esta dependente de aprovação do Corpo Legislativo caso houvessem de gozar de algum privilégio. (v) sua existência somente poderia ser provada por escritura pública ou pelos seus estatutos, bem como pelo ato do Poder Público que tivesse autorizado sua constituição, uma vez inscritos no até então existente 'Tribunal do Comércio' - condições, estas, essenciais para que pudessem dar início às suas atividades (...). (vi) seu capital era dividido em ações, e estas em frações, sendo possível emiti-las ao portador, devendo sua transmissão se dar por endosso e por lançamento nos registros da sociedade. (vii) enquanto não estivessem inscritas no Registro do Comércio, seus administradores ou diretores responderiam pessoal e solidariamente perante terceiros que com elas viessem a contratar; a partir do momento de referida inscrição a responsabilidade daqueles seria estabelecida em função do exercício do seu mandato." (VERÇOSA, Haroldo Malheiros Duclerc. Curso de direito comercial. v. 3. $2^{\text {a }}$ ed. São Paulo: Malheiros, 2011, pp. 56-57). VERÇOSA acrescenta que “(...) a necessidade de autorização governamental era um dos pontos mais problemáticos da questão, exigência diante da qual os interessados necessitavam passar por um longo e desgastante processo, que podia atravessar anos até a solução final (...)"(VERÇOSA, Haroldo Malheiros Duclerc. Curso de direito comercial. v. 3. $2^{\mathrm{a}}$ ed. São Paulo: Malheiros, 2011, p. 58)

9 ."Os anos de 1889 a 1891 , conhecidos como correspondentes ao período do encilhamento, viram a quebra da maior parte das 1.150 companhias então existentes em nosso país, vítimas de abusos e fraudes diversas e da sua própria fraqueza econômica. A legislação vigente não foi capaz de dar solução aos problemas então verificados (...) entre os quais: complexidade jurídica do ato constitutivo; as diversas relações dele emanadas, no seu entrelaçamento e dependência; os direitos e responsabilidades dos acionistas, administradores, fiscais, assembleias etc. (...)". (VERÇOSA, Haroldo Malheiros Duclerc. Curso de direito comercial. v. 3. $2^{\mathrm{a}}$ ed. São Paulo: Malheiros, 2011, pp. 59-60). Segundo CARVALHO,o encilhamento tratou-se de uma bolha econômica gerada a partir da adoção de uma política baseada em créditos livres aos investimentos industriais garantidos pelas emissões monetárias (CARVALHO, Ney O. O Encilhamento: anatomia de uma bolha brasileira (em português). São Paulo: Bovespa, 2004). O ato de encilhar, segundo BÁRBARA LEVY, refere-se às apostas que seriam o modo com que os especuladores atuavam na Bolsa de Valores com as empresas fantasmas (BÁRBARA Levy, Maria; NEUHAUS, Paulo (Coord.). Economia brasileira: uma visão histórica. Rio de Janeiro: Campus, 1980).
} 
empreendedores quanto investidores) carecia de segurança jurídica para voltar a existir e então se desenvolver.

Segundo VERGUEIRO ${ }^{10}$, o embrião da LSA está no PND, aprovado pela Lei 6.151, de 1974, durante o governo de Ernesto Geisel, com o intuito de estimular a produção industrial e, de forma geral, estabelecer os objetivos básicos, estratégia e plano de ação do governo nas áreas social e econômica.

O autor afirma que as diretrizes de tal plano econômico incluíam:

(...) a previsão para que a lei acionária obrigasse: o recebimento de dividendos mínimos às minorias societárias, a equivalência, em valor, das ações do bloco de controle e dos minoritários e o aperfeiçoamento dos mecanismos de auditoria passíveis de serem realizados pelo conselho fiscal, objetivos que não foram alcançados pela lei 6.404 promulgada em 1976. (...) Ainda no que se refere ao II PND, chama atenção o fato de que o Plano, juntamente com a lei acionária que lhe seguiu, preverem medidas que levassem à formação da grande empresa nacional, que deveria ter bons instrumentos de capitalização para estar apta a concorrer com a empresa estrangeira, que crescesse rapidamente num país que ainda estava construindo seu empresariado. ${ }^{11}$

Nas palavras de LAMY FILHO e BulHÕES PEDREIRA, à época da promulgação da LSA,

[o] conhecimento da evolução das economias industrializadas mostrava que o aumento de escala das empresas privadas nacionais poderia ocorrer por dois caminhos: (a) a formação de macroempresas institucionalizadas; e (b) a expansão das empresas médias existentes, pela associação de grupos empresariais e captação de capital de risco no mercado. (...) A lei procurou ainda aumentar a capacidade dos empresários brasileiros de alavancarem seus recursos próprios sem perder o controle da companhia, aumentando para $2 / 3$ (hoje reduzido para 1/2) o limite de emissão de ações preferenciais sem voto ou com voto restrito. ${ }^{12}$

\footnotetext{
${ }^{10}$.VERGUEIRO, Carlos Eduardo. Acordo de Acionistas e a Governança das Companhias. São Paulo: Quartier Latin, 2010, p. 108.

${ }^{11}$.VERGUEIRO, Carlos Eduardo. Acordo de Acionistas e a Governança das Companhias. São Paulo: Quartier Latin, 2010, pp. 108-109.

${ }^{12}$.BULHÕES PEDREIRA, José Luiz e LAMY FILHO, Alfredo. In Direito das Companhias. v. I. Rio de Janeiro: Forense, 2010, p. 796.
} 
Com isso, foram editadas, quase que concomitantemente, as leis 6.385, de 7 de dezembro de 1976, criadora da CVM, e a LSA. ${ }^{13}$

\subsubsection{A LSA}

Da forma atualmente regulada pela LSA (art. $1^{\circ}$ ), "a companhia ou sociedade anônima terá o capital dividido em ações, e a responsabilidade dos sócios ou acionistas será limitada ao preço de emissão das ações subscritas ou adquiridas." Além disso, nos termos do art. $2^{\circ}$ da LSA, a sociedade anônima "terá por objeto qualquer empresa de fim lucrativo, não contrário à lei, à ordem pública e aos bons costumes".

A relevância e o porte da empresa determina o tipo societário ${ }^{14}{ }^{15}$ de sua organização e, mais do que isso, sua estrutura de capital $^{16}$, fechado ou aberto ${ }^{17}$, e, no último caso, concentrado ou disperso.

\footnotetext{
13 "Durante a vigência do Decreto-lei 2.627/1940 veio à luz, em 1964, a Reforma Bancária, objeto da Lei 4.595, de 1964. Pouco depois, paralelamente àquele texto legal, foi editada a nossa primeira Lei do Mercado de Capitais, acima mencionada [Lei 4.728, de 1965], a qual dava ao BCB competência para cumular a tutela do mercado de capitais juntamente com a do mercado financeiro, debaixo da competência normativa do CMN. Neste último campo a atuação do BCB foi desastrosa - em vista, principalmente, da absoluta falta de experiência daquele órgão no campo em tela -, tendo havido um boom de crescimento desequilibrado do mercado de capitais, durante o qual se revelaram absolutamente inadequadas as bases econômicas das sociedades abertas, ao lado da crise institucional do órgão regulador, seguido de um grande crash, verificado em 1971. (...) de 1965 a 1970 dezenas de sociedade abertas foram autorizadas a operar pelo BCB, sem um exame eficiente (ou, mesmo, diante de nenhum exame) do seu projeto econômico. Nesse contexto, o volume de papéis negociados nas Bolsas de Valores aumentou sobremaneira, gerando uma falsa sensação de liquidez e de segurança dos investimentos. O mercado ficou verdadeiramente alucinado (repetindo-se o ocorrido no encilhamento), comprando qualquer papel que nele era apregoado (...) inevitável o crash, nem por isto seu efeito foi menos devastador, dando-se o afastamento dos investidores desiludidos com suas perdas. Daí o desafio do legislador na busca de um novo modelo para nosso mercado de capitais, que passava concomitantemente por uma nova Lei das Sociedades Anônimas, cuja disciplina seria voltada em boa parte para aquele setor, a par de uma nova lei específica para o próprio mercado, que viesse a prever a criação de um órgão especializado para sua disciplina (a Comissão de Valores Mobiliários - CVM) e as mudanças necessárias na Lei do Anonimato." (VERÇOSA, Haroldo Malheiros Duclerc. Curso de direito comercial. v. 3. $2^{\mathrm{a}}$ ed. São Paulo: Malheiros, 2011, pp. 61-62)

${ }^{14}$ Interessante o seguinte comentário de ADAMEK: "Numericamente consideradas, apenas, as sociedades anônimas (sobretudo as abertas) são pouco expressivas; contudo, quando a análise é deslocada da pura e simples contagem de sociedades para a verificação de dados de natureza econômica - tais como lucro, faturamento, retorno sobre capital investido, número de empregos gerados etc. - sobressaem, inconteste, a sua preponderância sobre as demais sociedades e a sua predileção pelas grandes empresas." (VON ADAMEK, Marcelo Vieira. Responsabilidade civil dos administradores de S/A e as ações correlatas. São Paulo: Saraiva, 2009, p. 4)

${ }^{15}$ De acordo com as informações mais recentes disponibilizadas pelo DNRC, em 2005 foram constituídas: (i) 240.306 firmas individuais; (ii) 246.722 sociedades limitadas; e (iii) 1.800 sociedades anônimas. Desde 2001 até 2005, foram constituídas: (i) 1.147.073 firmas individuais; (ii) 1.196.271 sociedades limitadas; e (iii) 6.694 sociedades anônimas. Fonte: <http://www.dnrc.gov.br/Estatísticas/Caep0100.htm> (acesso em: 24 set. 2013).
} 
A criação da sociedade anônima permitiu o fortalecimento do mercado de capitais de risco no país e, consequentemente, da economia brasileira.

A importância da sociedade anônima, no Brasil, passa pelo reconhecimento de ela se tratar de um dos poucos fatos jurídicos que antecederam, organizaram e estimularam o fato econômico. Em outras palavras, se é verdade que em regra a regulação persegue os eventos econômicos, buscando regulamentá-los, prever seus principais gargalos e responsabilizar os agentes infratores, a sociedade anônima teve função econômica distinta. Ao identificar a demanda do incipiente empresariado e os potenciais benefícios nacionais do desenvolvimento da atividade privada, o legislador tratou de criar o instrumento necessário para canalizar tal demanda.

A partir disso, o fato econômico teve as condições jurídicas necessárias para se desenvolver e, assim, estimular o desenvolvimento da economia nacional.

\subsection{Natureza jurídica da sociedade anônima}

Conforme a lição de VERÇOSA: "É importante verificar a natureza jurídica do instituto (...) para o fim da aplicação das regras adequadas quando do surgimento de questões jurídicas àquele relacionadas (...)" ${ }^{m 18}$.

Diversas são as teorias acerca da natureza jurídica da sociedade anônima. Entre as principais teorias destacamos: (i) contratual $^{19}$; (ii) ato coletivo ou complexo ${ }^{20}$; (iii) ato corporativo $^{21}$; e (iv) instituição ${ }^{22}$.

\footnotetext{
${ }^{16}$ Vide o caput art. $4^{\text {o }}$ da LSA, "Para os efeitos desta lei, a companhia é aberta ou fechada conforme os valores mobiliários de sua emissão estejam ou não admitidos à negociação no mercado de valores mobiliários".

17 Pelas informações mais recentes disponibilizadas pela CVM, desde 2001 até julho de 2013 foram concedidos 434 registros iniciais de companhia aberta (sendo que em 2012 foram concedidos 30 registros de companhias abertas e no ano de 2013 até setembro haviam sido concedidos 21 registros. Destaque para os anos de 2006 e 2007 em que foram concedidos, respectivamente, 52 e 85 registros). Fonte: <http://www.cvm.gov.br/asp/cvmwww/ciasabertas/registros/RegistrosAno.asp> e $\quad$ <ttp:// www.cvm.gov.br/port/public/ASE/icvm/informexterno.asp?update=13062013 > (acesso em: 24 set. 2013)

${ }^{18}$ VERÇOSA, Haroldo Malheiros Duclerc. Curso de direito comercial. v. 3. $2^{\mathrm{a}}$ ed. São Paulo: Malheiros, 2011, pp. 306 e 309.

19 Segundo VERÇOSA trata-se de uma "modalidade de contrato plurilateral, associativo ou aberto" (VERÇOSA, Haroldo Malheiros Duclerc. Curso de direito comercial. v. 3. $2^{\mathrm{a}}$ ed. São Paulo: Malheiros, 2011, p. 65). Neste sentido também se posiciona CARVALHOSA: “(...) o negócio constitutivo de sociedade -
} 
VERÇOSA, por sua vez, faz interessante análise do tema ao comparar a natureza jurídica do ato constitutivo da companhia fechada e o da aberta. Segundo ele, tendo em vista o caráter institucional da companhia aberta, poder-se-ia vislumbrar um problemático entendimento no sentido de atribuir naturezas jurídicas distintas dependendo da forma aberta ou fechada do capital da companhia ${ }^{23}$.

Todavia, de forma a afastar esta potencial confusão, VERÇOSA esclarece que as especifidades da companhia aberta não deveriam ser entendidas como modificadoras da natureza jurídica da sociedade anônima. Isso porque sua constituição será sempre de natureza contratual, sendo que nascendo ou se transformando em companhia aberta, outros princípios deverão ser observados ${ }^{24}$.

bem como o dos acordos de controle e de voto minoritário - enquadram-se entre os contratos plurilaterais de organização, (...) tal como exposto por Ascarelli." (CARVALHOSA, Modesto. Acordo de Acionistas. São Paulo: Saraiva, 2011, pp. 153-154). O autor aproveita para ilustrar a dificuldade que havia de a doutrina aceitar a teoria contratual, já que muitos a associavam ao contrato bilateral (i.e., reciprocidade de prestações). Ocorre que a brilhante construção do conceito do contrato plurilateral feita por ASCARELLI afastou tais críticas e representou um verdadeiro marco para o entendimento e evolução do tema.

20 “(...) Há os que definem o negócio constitutivo societário como ato coletivo ou ato complexo, argumentando a insuficiência das teorias contratualistas para explicar as relações emergentes da constituição de uma sociedade, especialmente tendo-se em vista a ausência de sinalagma entre as obrigações diversas assumidas, ou seja: há uma relação de recíproca dependência entre elas. A diferença entre ato coletivo e ato complexo, conforme Messineo, está em que no ato complexo as várias vontades dos declarantes fundem-se em uma vontade unilateral, perdendo sua individualidade. Já no ato coletivo as várias vontades unem-se, mas permanecem distintas e discerníveis no interior do ato." Conforme demonstra CARVALHOSA, neste linha posicionam-se Trajano Valverde, além de um grande número de juristas alemães e italianos, como Kuntze, Lehmann, Rocco, Salandra, Messineo e outros. (CARVALHOSA, Modesto. Acordo de Acionistas. São Paulo: Saraiva, 2011, p. 152)

21 "Outra escola apresenta a teoria do ato corporativo para identificar a natureza da sociedade, fundando-se em Von Gierke. (...) Explica-se que as vontades individuais constituem uma função, sendo uma espécie de manifestação antecipada da personalidade do novo ente jurídico - a sociedade" (CARVALHOSA, Modesto. Acordo de Acionistas. São Paulo: Saraiva, 2011, p. 153)

22 "Cabe, ainda, referência à teoria da instituição, elaborada por Hauriou e Rénard. Funda-se na noção de organismo corporativo, ressaltando-se, no entanto, seu caráter quase público, pois constituído com finalidade e meios superiores àqueles dos indivíduos que o compõem." (CARVALHOSA, Modesto. Acordo de Acionistas. São Paulo: Saraiva, 2011, p. 153)

${ }^{23}$ “'(...) ente híbrido enquanto companhia aberta e tão somente contratualista enquanto sociedade fechada. E veja-se que de fechada pode evoluir para aberta e vice-versa - do que resultaria uma consequente mudança em sua natureza jurídica, que seria instável. Quando se pensa em ordenamentos jurídicos em base sistêmica, a visão dúplice da companhia mostra-se extremamente problemática. (...)" (VERÇOSA, Haroldo Malheiros Duclerc. Curso de direito comercial. v. 3. $2^{\mathrm{a}}$ ed. São Paulo: Malheiros, 2011, p. 66)

24 "Pensamos que a questão em foco se coloca em dois planos distintos: o da natureza jurídica do ato constitutivo da sociedade e de sua permanência ao longo do tempo (com as alterações que se revelarem oportunas, ao alvedrio da assembleia-geral) e o da proteção aos acionistas e/ou investidores quando a companhia se transforma ou já nasce como aberta, para o fim de lhe ser possível ter valores mobiliários negociados (...) Não se trata, portanto, da existência de uma base institucionalista na Lei 6.404/1976, mas, tradicionalmente, do mesmo contrato plurilateral associativo ou aberto regedor de toda e qualquer sociedade. Este fato nos permite, justamente, isolar o estudo da sociedade anônima em si mesma, na sua estrutura básica (naturalmente adequada ao do tipo fechado), deixando para outro momento a modalidade aberta, na qual seus valores mobiliários são negociados no mercado de capitais, com seus princípios próprios." (VERÇOSA, 
Ao que nos parece, o entendimento doutrinário prevalecente é o de que a natureza do ato constitutivo da sociedade anônima é contratual, mais especificamente, o contrato plurilateral (tal qual vislumbrado e exposto por ASCARELLI ${ }^{25}$ ). Em se tratando de companhia aberta, seus princípios diferenciados (eminentemente a proteção à poupança popular e o amplo dever de informação) não servem para modificar sua natureza, mas para conferir outro tratamento ao que se entenderia por interesse social (tratado no subcapítulo 2.5 abaixo).

\subsection{Estrutura de propriedade da sociedade anônima. Crítica à}

\section{LSA}

Feitas as considerações iniciais acima sobre a evolução da sociedade anônima no Direito Comparado e no Brasil, analisaremos um pouco de sua estrutura de propriedade, i.e., as possíveis formas de organização do poder do acionista a fim de mais à frente termos condições de averiguar eventuais impactos à vinculação do poder gerencial ao poder do acionista.

Muito embora as formas concentrada e dispersa (ou pulverizada) de propriedade acionária sejam possíveis e existentes no $\operatorname{Brasil}^{26}$, a tradição de concentração de capital por

Haroldo Malheiros Duclerc. Curso de direito comercial. v. 3. $2^{\mathrm{a}}$ ed. São Paulo: Malheiros, 2011, p. 66 e 68). Também neste sentido a lição de REQUIÃO: "Pode-se admitir que embora a sociedade anônima configure, após sua formação, uma instituição, não deixa ela de ser formada pelo contrato, e este da espécie plurilateral. Como instituição, ela está voltada para a consecução do 'bem comum', visando primacialmente aos altos interesses coletivos, desvanecendo um tanto o interesse privado, perseguido pelos acionistas. Como contrato, regula os interesses pessoais de seus membros.” (REQUIÃO, Rubens. Curso de direito comercial. v. 2. 25 . ed. Atual. por Rubens Edmundo Requião. São Paulo: Saraiva, 2003, p. 15)

25 ASCARELLI, Tullio. "O contrato plurilateral”. In Problemas das sociedades anônimas e direito comparado. São Paulo: Saraiva, 1945, p. 274 e seguintes). Nas palavras de VERÇOSA: “(...) no contrato plurilateral todas as partes são titulares de direitos e de obrigações, concomitantemente. (...) há um escopo comum entre as partes, o qual qualifica cada uma das adesões individuais ao negócio, como seja a reunião de bens e esforços para que o objetivo social possa ser economicamente realizado. (...) sua função econômica não é alcançada quando as partes cumprem suas obrigações (...) os direitos das partes são do mesmo tipo, idênticos na qualidade, diferentes na quantidade." (VERÇOSA, Haroldo Malheiros Duclerc. Curso de direito comercial. v. 2. $2^{\text {a }}$ ed. São Paulo: Malheiros, 2010, pp. 56-58).

26 "No mais das vezes, a definição por uma estrutura societária ou outra tem raízes históricas nas respectivas economias. É o que ocorre nos EUA com a desconcentração acionária e na Alemanha e o no Brasil, inversamente, com a concentração acionária." (SALOMÃO FILHO, Calixto. O Novo Direito Societário. $4^{\mathrm{a}}$ ed. São Paulo: Malheiros, 2011, p. 58) 
aqui sempre foi um fato, inclusive nas companhias abertas listadas em segmentos especiais de listagem da BM\&FBovespa (Nível 1, Nível 2 e Novo Mercado) ${ }^{27}$.

Segundo o premiado trabalho de GORGA e GELMAN ${ }^{28}$, esta parece continuar sendo a realidade da estrutura de propriedade acionária brasileira. A partir da análise conduzida pelas autoras, em maio de 2012, de dados sobre a estrutura de propriedade de 181 companhias listadas nos segmentos especiais de governança da BM\&FBovespa (sendo 128 do Novo Mercado, 20 do Nível 2 e 33 do Nível 1), foi identificado que em 107 companhias o maior acionista detinha menos de $50 \%$ do capital votante (sendo 88 do Novo Mercado, 10 do Nível 2 e 9 do Nível 1), e em 74 companhias, o maior acionista detinha mais de 50\% do capital votante. Do universo de 107 companhias sem controlador majoritário, 55 possuíam acordo de acionistas $(51,4 \%)^{29}$.

Essa era a realidade à época da promulgação da $\operatorname{LSA}^{30}$ e, por esse motivo, pretendeu o legislador regular a sociedade anônima para aquele contexto ${ }^{31}$.

\footnotetext{
${ }^{27}$ Sobre a comparação entre as estruturas dispersa e concentrada: (i) MUNHOZ afirma que: “(...) a avaliação comparativa dos modelos de capital concentrado e pulverizado, a despeito de significativa corrente da literatura econômica e jurídica sustentar a superioridade do primeiro sobre o segundo, não conduz a conclusões seguras, dada a ausência de comprovação empírica que evidencie a maior eficiência (melhor desempenho) das companhias com capital disperso." (MUNHOZ, Eduardo Secchi. Quem deve comandar a companhia? Alocação do poder empresarial: sistema de freios e contrapesos. In Estudos em Homenagem a Modesto Carvalhosa. São Paulo: Saraiva, 2012, p. 507); e (ii) GILSON defende um fator de eficiência da estrutura de capital concentrado. Considerando que o controlador possui uma parcela significativa da companhia, ele tende a dedicar mais atenção e efetivamente monitorar os administradores. E devido a essa proximidade e menores custos de obtenção de informação, estaria em melhor posição para identificar problemas primeiro. Assim, em mercados concentrados eficientes, a concentração serve de meio ao combate ao conflito de agência, i.e., os custos da extração de benefícios privados é menor do que o de monitorar os administradores. (GILSON, R. Controlling shareholders and corporate governance: complicating the comparative taxonomy. ECGI Working Paper No. 49. 205, p. 12. Disponível in $<\mathrm{http}: / /$ ssrn.com/abstract=784744> Último acesso em 18.01.2014)

${ }^{28}$ GORGA, Érica; GELMAN, Marina. O Esvaziamento Crescente do Conselho de Administração como Efeito da Vinculação de seu Voto a Acordos de Acionistas no Brasil. Prêmio IBGC Itaú Academia e Imprensa, 2012, pp. 10-11.

${ }^{29}$ Segundo CALIXTO SALOMÃo: "A pesquisa realizada concluiu que além da alta concentração do controle acionário, a estrutura de propriedade do controle nas empresas brasileiras: (i) é caracterizada pelo controle familiar, compartilhado ou exercido por multinacionais; (ii) os acionistas minoritários são pouco ativos e os seus interesses não são completamente reconhecidos; e (iii) há alta sobreposição entre propriedade acionária e gestão executiva. Além disso, os conselhos de administração das empresas são compostos por conselheiros internos, representantes dos acionistas majoritários, e têm estruturas informais, com processos não definidos, e há pouca clareza na divisão dos papéis de conselho executivo nas empresas familiares." (SALOMÃO FILHO, Calixto. O Novo Direito Societário. $4^{\mathrm{a}}$ ed. São Paulo: Malheiros, 2011, pp. 77-78)

30 "Não tentou [o legislador] criar uma contra tendência, mas sim regulamentar a realidade existente. Com isso sem dúvida aprofundou, nesses 30 anos de vigência da Lei 6.404, a dependência do próprio modelo concentracionista. Pode-se criticar o legislador brasileiro pela falta de idealismo, mas não pela ausência de realismo. O sistema foi elaborado em torno da figura do acionista controlador, verdadeiro centro decisório da sociedade." (SALOMÃO FILHO, Calixto. O Novo Direito Societário. $4^{\mathrm{a}}$ ed. São Paulo: Malheiros, 2011, pp. 98-99)
} 
Embora a LSA (em muito) tenha contribuído para o crescimento econômico do país desde sua promulgação, é certo que o mercado de capital de risco no Brasil ainda não atingiu o estágio desejado (e originariamente imaginado à época da promulgação da LSA).

Ainda que tenha sido visionária em regular alguns institutos típicos de mercados dispersos mais avançados (e.g., oferta pública para aquisição de controle e pedido público de procuração) ${ }^{32}$, a boa fama da LSA deve-se muito mais à sua correlação com a realidade brasileira, tecnicismo e a criação de uma sistemática própria de direitos e responsabilidades ao acionista controlador ${ }^{33}$.

Todavia, a eficácia ${ }^{34}$ de suas disposições é algo bastante questionável e capaz de estimular a extração de benefícios privados do controle por parte do acionista controlador (i.e., extração de recursos da companhia ao benefício isolado do controlador, em prejuízo dos demais acionistas e stakeholders $)^{35}$, fato este que mina a formação de um competitivo mercado de capitais como alternativa à intermediação financeira.

${ }^{31}$ GILSON afirma que a experiência tem mostrado que em países menores ou economicamente mais frágeis, ainda que a lei seja boa o suficiente para evitar a extração de benefícios privados pecuniários, muito provavelmente a extração de benefícios não pecuniários estimulará a concentração de capital. O exemplo sobre a comparação entre a Suécia e os Estados Unidos é bastante ilustrativo neste sentido. (GILSON, R. Controlling shareholders and corporate governance: complicating the comparative taxonomy. ECGI Working Paper No. 49. 205, pp. 29-32. Disponível in <http://ssrn.com/abstract=784744> Último acesso em 18.01.2014).

32 “(...) Além disso, a lei [LSA] compreende dois novos institutos, formados nas economias em que existem as macroempresas institucionalizadas, que são essenciais para evitar a perpetuação de administradores ineficientes - as proxy fights (lutas por procurações) e a oferta pública para aquisição de controle. (...) Como instrumento para o aumento de escala da empresa privada brasileira a lei regula o acordo de acionistas (...).”(BULHÕES PEDREIRA, José Luiz e LAMY FILHO, Alfredo. In Direito das Companhias. v. I. Rio de Janeiro: Forense, 2010, p. 796).

${ }^{33}$ Para CALIXTO SALOMÃO: "Nunca houve na gestação da lei societária brasileira real intenção de criar entidades separadas de seus controladores, aptas a serem geridas profissionalmente e apenas fiscalizadas por controladores ou terceiros. A característica funcional básica não é, portanto, a concentração acionária, mas a concentração de poderes em torno da figura do controlador. (...) toda a estrutura societária brasileira é voltada a erigir o controlador como verdadeiro centro parassocietário de poder, ao qual todos os poderes e responsabilidades são referidos. Como já alhures mencionado, talvez o melhor exemplo dessa característica funcional esteja na imputação direta ao controlador (e não à sociedade) dos deveres institucionais previstos no artigo 116 da lei societária. Ora, não é de se espantar que, em presença de uma tal definição funcional, seja difícil introduzir qualquer discussão sobre estruturas societárias, baseadas em outro padrões funcionais. Daí a dificuldade da tarefa no sistema brasileiro.” (SALOMÃO FILHO, Calixto. O Novo Direito Societário. $4^{\mathrm{a}}$ ed. São Paulo: Malheiros, 2011, p. 98).

34 "(...) Trata-se, acima de tudo, de assegurar o cumprimento da norma (enforcement)" (MUNHOZ, Eduardo Secchi. Quem deve comandar a companhia? Alocação do poder empresarial: sistema de freios $e$ contrapesos. In Estudos em Homenagem a Modesto Carvalhosa. São Paulo: Saraiva, 2012. pp. 505-517, p. 510)

${ }^{35}$ (i) GILSON classifica os benefícios privados do controle em dois tipos, os pecuniários e os não pecuniários. Os primeiros consistiriam na extração de recursos da companhia (tais como aqueles auferidos em transações 
Portanto, por mais respeitada e coerente (com nossa realidade de concentração de capital) que seja a LSA (e proporcionalmente complexa a função de alterá-la), a lei pode ser capaz também de criar e instrumentalizar modelos ${ }^{36}$ ainda incipientes que sejam capazes de estimular o desenvolvimento da economia nacional. Isto é, ela não precisa estar apenas conformada à realidade (de 1976, de 2001 ou de hoje), mas também criar novos modelos ${ }^{37}$.

Alguns autores tentaram explicar essa dificuldade de inovação. Para eles, ainda que a pressão econômica por competitividade crie um forte movimento de convergência de sistemas de direito societário no mundo ${ }^{38}$, diversos valores locais geram também intensas

entre a companhia e outras empresas detidas pelo acionista controlador); e os não pecuniários em benefícios representados por status social e político, por exemplo. (GILSON, R. Controlling shareholders and corporate governance: complicating the comparative taxonomy. ECGI Working Paper No. 49. 205, pp. 2728. Disponível in <http://ssrn.com/abstract=784744> Último acesso em 18.01.2014); (ii) GILSON e GORDON acrescentam que as três maneiras pelas quais os acionistas controladores podem obter benefícios privados do controle são: apropriação desproporcional de receitas da companhia, compra compulsória das ações dos demais acionistas, praticamente expulsando-os da companhia, e venda do controle sem repartição do prêmio com os demais acionistas (GILSON, R. E GORDON, J. Controlling controlling shareholders. In University of Pennsylvania Law Review 152, 2003, apud, VERGUEIRO, Carlos Eduardo. Acordo de Acionistas e a Governança das Companhias. São Paulo: Quartier Latin, 2010); (iii) Também neste sentido, FRANCO e SZTAJN ensinam que: “(...) Self dealing ou negociação com sociedades sob controle do mesmo grupo, aparecem como um dos meios mais frequentes de transferência de riqueza, de aproveitamento de oportunidades da companhia por seus controladores." (FRANCO, Vera Helena de Melo; SZTAJN, Rachel. Direito Empresarial II: sociedade anônima, mercado de valores mobiliários. $2^{\mathrm{a}}$ ed. ver. atual. e ampl. São Paulo: Revista dos Tribunais, 2009, p. 192); e (iv) OIOLI e VEIGA também contribuem para o entendimento dos benefícios privados de controle: "À luz do Direito brasileiro, um desses claros benefícios é o reconhecimento do prêmio de controle previsto no art. 254-A da Lei 6.404/1976." (OIOLI, Erik Frederico e VEIGA, Marcelo Godke. Convergência e divergência em sistemas de mercados de capitais: O caso brasileiro. In CASTRO, Rodrigo R. Monteiro de; MOURA AZEVEDO, Luis André N. (Coord.). Poder de Controle e Outros Temas de Direito Societário e Mercado de Capitais. São Paulo: Quartier Latin, 2010, p. 341)

36 "Se os modelos jurídicos nascem da observação da realidade, não é menos verdade que exercem influência sobre ela, acelerando ou mesmo determinando transformações das estruturas sociais, numa espécie de relação simbiótica. Há tempos, o Direito não é visto como mero instrumento de pacificação de conflitos e, portanto, de manutenção das estruturas sociais. Além de exercer a função de harmonização da sociedade, o Direito constitui instrumento de implementação de políticas públicas, atuando, portanto, de forma prospectiva, para a transformação da realidade, no sentido da consecução do bem comum. (...) exigindo que os modelos jurídicas sejam operacionais, não esquemas ideiais, pois não subsistem como algo desligado da realidade, vivendo antes em função dela." (MUNHOZ, Eduardo Secchi. Empresa contemporânea e direito societário - poder de controle e grupos de sociedades. São Paulo: Juarez de Oliveira, 2002, pp. 12-13)

37 "O direito e as instituições jurídicas trazendo consigo valores, (...) têm força reformista bem superior a que imaginamos. Introduzidos por via legislativa ou voluntária - contratual (e aqui o Novo Mercado representa sem dúvida um belo exemplo) - acabam por fazer prevalecer sua força ética. (...)" (SALOMÃO FILHO, Calixto. O Novo Direito Societário. $4^{\mathrm{a}}$ ed. São Paulo: Malheiros, 2011, p. 103)

${ }^{38}$ Vide os excelentes trabalhos de HANSMANn e KRAAKMAN (The End of History for Corporate Law. Georgetown Law Journal 89. 2001, pp. 439 e seguintes, pp. 454-455) e GILSON (Globalizing corporate governance: convergence of form or function. American Journal of Comparative Law 49. 2001, pp. $329 \mathrm{e}$ seguintes). 
resistências à adaptação de novos modelos ${ }^{39}$. Trata-se da denominada teoria do "path dependence”, vislumbrada por BEBCHUK e $\operatorname{ROE}^{40}$. Tal teoria será novamente abordada ao longo do desenvolvimento deste trabalho, especialmente para tratar das alterações à LSA realizada em 2001 (i.e., inserção dos $\S \S 8^{\circ}$ e $9^{\circ}$ ao art. 118).

Independentemente da prevalência ideológica do modelo de estrutura proprietária concentrada ou pulverizada ${ }^{41}$, parece-nos que a criação de uma (desenvolvida) alternativa à intermediação financeira seria extremamente salutar ao crescimento econômico nacional. Em outras palavras, ainda que preservemos nossa cultura concentracionista, a atividade empresarial seria estimulada pela efetiva concorrência entre dois potenciais financiadores (bancos e poupança popular) $^{42}$.

\footnotetext{
${ }^{39}$ Vide as obras de ROE e BEBCHUCK (A theory of path dependency in corporate governance and ownership. Stanford Law Review vol. 52, 1999, p. 775-808), e ROE (Political Determinants of Corporate Governance: Political Context, Corporate Impact. Oxford University Press, 2006)

${ }^{40}$ (i) "De acordo com Lucian Bebchuk e Mark Roe, o determinismo ocorre devido a um dirigismo estrutural (...), pelo qual a estrutura de concentração/difusão acionária inicial de uma economia acaba por influenciar as estruturas subsequentes (no tempo) para que mantenham as mesmas características; e a um dirigismo normativo (...), nos termos do qual a legislação societária inicial também acaba por favorecer a perpetuação de seus postulados." (BEBCHUCK, L. A. e ROE, M. J. A theory of path dependency in corporate governance and ownership. Stanford Law Review vol. 52, 1999, p. 775-808, apud, VERGUEIRO, Carlos Eduardo. Acordo de Acionistas e a Governança das Companhias. São Paulo: Quartier Latin, 2010, p. 98). (ii) VERGUEIRO ensina ainda que “(...) a path dependence oferece caminhos de análise que levam a entender o porquê da legislação nacional, em regra, preserva a posição ocupada pelos controladores em detrimento dos minoritários e das demais partes interessadas na condução dos negócios sociais. (...) path dependence, expressão de difícil tradução para o português, significa que atitudes do passado influenciam, de forma forte, chegando até a determinar o presente e o futuro - ou seja, o passado atua como elemento gerador do presente e do futuro." (VERGUEIRO, Carlos Eduardo. Acordo de Acionistas e a Governança das Companhias. São Paulo: Quartier Latin, 2010, p. 95).

${ }^{41}$ Boa parte da doutrina entender que a dispersão acionária representaria uma evolução e, portanto, um modelo superior ao de capital concentrado: (i) "A diluição de controle, como toda diluição de poder, acaba por permitir um melhor equilíbrio entre os vários interesses envolvidos pelas grandes companhias. Berle e Means já se referiam ao controle gerencial como uma forma de poder tecnocrático capaz de arbitrar os conflitos entre os vários interesses envolvidos na sociedade" (SALOMÃO FILHO, Calixto. O Novo Direito Societário. $4^{a}$ ed. São Paulo: Malheiros, 2011, pp. 81-82); (ii) HANSMANN e KRAAKMAN entendem que há uma tendência mundial à formação de poupança popular e consequente dispersão do capital das companhias (HANSMANN, Henry e KRAAKMAN, Reinier. The End of History for Corporate Law. Georgetown Law Journal 89. 2001, pp. 439 e seguintes, pp. 454-455); e (iii) GILSON afirma que a estrutura de capital adotada pelos Estados Unidos e Reuno Unido é vista como o estágio final da evolução da governança corporativa. Segundo tal autor, a ajuda financeira pós-crise do leste asiático em 1997-1998 foi condicionada não apenas ao aspecto macroeconômico, mas também na reforma da governança corporativa. (GILSON, R. Controlling shareholders and corporate governance: complicating the comparative taxonomy. ECGI Working Paper No. 49. 205, p. 7. Disponível in <http://ssrn.com/abstract=784744> Último acesso em 18.01.2014).

${ }^{42}$ CAMARGO e BOCATER comentam que "O fenômeno da evolução de um sistema capitalista concentrado para outro em que sucede uma efetiva pulverização da propriedade, através de grandes companhias abertas, somente prolifera quando encontra ressonância numa ordem jurídica que proteja esses interesses atomizados. (...)" (CAMARGO, João Laudo e BOCATER, Maria Isabel do Prado. Conselho de Administração: seu Funcionamento e Participação de Membros Indicados por Acionistas Minoritários e Preferencialistas. In Jorge Lobo (Coord.). Reforma da Lei das Sociedades Anônimas - Inovações e Questões Controvertidas da Lei 10.303, de 31.10.2001. Rio de Janeiro: Forense, 2002, p. 397).
} 
Entre os inúmeros fatores que poderiam contribuir para o estágio ideal mencionado acima, passaríamos certamente por uma signativa melhora de eficiência do nosso atual sistema de capital concentrado ${ }^{43}$.

Assim, imaginamos que uma LSA mais eficaz e reguladora das duas realidades de estrutura de propriedade (concentração e dispersão) ${ }^{44}$ seja capaz de oferecer condições ao mercado de capitais de se desenvolver ${ }^{45}$ ainda mais e passar a ser uma efetiva alternativa ao financiamento bancário (ainda que preservemos nossa tradição e tendência concentracionista) $^{46}$.

\subsection{Estrutura administrativa da sociedade anônima. A teoria}

\section{organicista}

43 “(...) Da eficiência dessas regras depende o resultado de assegurar que o acionista exerça seu poder no sentido do interesse social. Ante uma atuação ineficiente de tais mecanismos de monitoramento, abre-se ao acionista controlador ampla possibilidade para a obtenção de benefícios privados do controle, ou seja, para extrair riqueza da companhia em seu benefício pessoal, em detrimento dos demais acionistas e stakeholders. (...)" (MUNHOZ, Eduardo Secchi. Quem deve comandar a companhia? Alocação do poder empresarial: sistema de freios e contrapesos. In Estudos em Homenagem a Modesto Carvalhosa. São Paulo: Saraiva, 2012. pp. 505-517, p. 509).

${ }^{44}$ GILSON aponta a existência de parcela significativa de companhias com capital concentrado nos Estados Unidos, tais como Dreamworks e Google, assim como muitas companhias com capital disperso na Suécia, país tipicamente de estrutura concentrada. Isso significa que embora existam grandes diferenças entre os dois sistemas, a tendência é justamente a coexistência de ambas as estruturas, inclusive dentro de cada subsistema (divergindo, portanto, da opinião de HANSMANN e KRAAKMAN mencionada acima acerca da tendência à dispersão). Com isso, o que se pode concluir é que independentemente da preferência por este ou aquele sistema (de concentração ou dispersão), é fundamental que ambos sejam eficientes. (GILSON, R. Controlling shareholders and corporate governance: complicating the comparative taxonomy. ECGI Working Paper No. 49. 205, pp. 27-28. Disponível in <http://ssrn.com/abstract=784744> Último acesso em 18.01.2014).

${ }^{45}$ VERGUEIRO, citando BLACK, apresenta quatro motivos que evidenciam a importância do mercado para a economia: "(i) recursos obtidos via mercado podem ser encarados como sendo financiamento de longo-prazo, mais estratégicos para as companhias do que os usuais empréstimos de curto-prazo oferecidos pelos bancos; (ii) a existência de parcelas elevadas de financiamento concedido pelos bancos pode ser prejudicial para a economia de um país porque bancos são extremamente vulneráveis em face de inadimplência - o fato de bancos serem intermediários financeiros demonstra o risco que podem exercer para a economia; (iii) um mercado de valores mobiliários fraco ou inexistente leva companhias a procurarem também obter financiamento interno, isto é, proporcionado por outras empresas do mesmo grupo, o que cria um ambiente no qual a formação de conglomerados passa a ser estimulada - em regra, conglomerados são menos eficientes do que empresas 'individuais', além de existir o risco de que os problemas existentes em uma área de atuação do grupo levem as demais a também enfrentarem problemas; e (iv) mercados de valores mobiliários fortes auxiliam o desenvolvimento nacional porque permitem a existência de investimentos de venture capital, além de permitirem, também, o ingresso de investimento estrangeiro no país." (VERGUEIRO, Carlos Eduardo. Acordo de Acionistas e a Governança das Companhias. São Paulo: Quartier Latin, 2010, pp. 34-35)

${ }^{46}$ Nesse sentido, CALIXTO SALOMÃo: “O efeito dessa possível popularização é sabido. Um mercado de capitais realmente ativo torna-se o mais efetivo instrumento de transformação de poupança em investimento, exatamente porque elimina a intermediação financeira entre ambos. Além de promover o crescimento econômico, é capaz de torná-lo menos dependente da variação da taxa de juros e dos dogmas neoclássicos dominantes para sua determinação." (SALOMÃO FILHO, Calixto. O Novo Direito Societário. $4^{\mathrm{a}}$ ed. São Paulo: Malheiros, 2011, p. 88) 
Saber se o acionista pode vincular a administração exige um prévio entendimento da estrutura administrativa da sociedade anônima.

\author{
Na rica lição de BARRETO FILHO:
}

Em sentido formal, a administração da sociedade anônima compreende o conjunto dos órgãos instituídos para a consecução do objeto social em sentido material, é o conjunto das funções necessárias ao desempenho, pela sociedade anônima, de sua peculiar atividade empresarial. ${ }^{47}$

Integram a estrutura administrativa da companhia, assim, os órgãos previstos em $\mathrm{lei}^{48}$, quais sejam, a assembleia geral $^{49}$, o conselho de administração $^{50}$, a diretoria ${ }^{51}$, o conselho fiscal ${ }^{52}$, bem como aqueles previstos pelo estatuto social, os denominados órgãos técnicos e consultivos ${ }^{53}$.

${ }^{47}$ BARRETO FILHO, Oscar. Estrutura Administrativa das Sociedades Anônimas. In Revista de Direito Mercantil, Industrial, Econômico e Financeiro. n ${ }^{\mathrm{a}}$ 24, pp. 65-74, p.65.

48 "A LSA prescreve que toda companhia tenha, necessariamente, três órgãos - a assembleia geral, a Diretoria e o Conselho Fiscal. As com capital autorizado, as abertas e as sociedades de economia mista devem ter, além destes, o Conselho de Administração." (BULHÕES PEDREIRA, José Luiz e LAMY FILHO, Alfredo. In Direito das Companhias. v. I. Rio de Janeiro: Forense, 2010, p. 803)

${ }^{49}$ Art. 121 da LSA: "A assembléia-geral, convocada e instalada de acordo com a lei e o estatuto, tem poderes para decidir todos os negócios relativos ao objeto da companhia e tomar as resoluções que julgar convenientes à sua defesa e desenvolvimento."

${ }^{50}$ Art. 142 da LSA: "Compete ao conselho de administração: I - fixar a orientação geral dos negócios da companhia; II - eleger e destituir os diretores da companhia e fixar-lhes as atribuições, observado o que a respeito dispuser o estatuto; III - fiscalizar a gestão dos diretores, examinar, a qualquer tempo, os livros e papéis da companhia, solicitar informações sobre contratos celebrados ou em via de celebração, e quaisquer outros atos; IV - convocar a assembléia-geral quando julgar conveniente, ou no caso do artigo 132; V manifestar-se sobre o relatório da administração e as contas da diretoria; VI - manifestar-se previamente sobre atos ou contratos, quando o estatuto assim o exigir; VII - deliberar, quando autorizado pelo estatuto, sobre a emissão de ações ou de bônus de subscrição; VIII - autorizar, se o estatuto não dispuser em contrário, a alienação de bens do ativo não circulante, a constituição de ônus reais e a prestação de garantias a obrigações de terceiros; IX - escolher e destituir os auditores independentes, se houver (...)."

${ }^{51}$ Art. 144 da LSA: "No silêncio do estatuto e inexistindo deliberação do conselho de administração (artigo 142 , n. II e parágrafo único), competirão a qualquer diretor a representação da companhia e a prática dos atos necessários ao seu funcionamento regular."

${ }_{52}$ Art. 163 da LSA: "Compete ao conselho fiscal: I - fiscalizar, por qualquer de seus membros, os atos dos administradores e verificar o cumprimento dos seus deveres legais e estatutários; II - opinar sobre o relatório anual da administração, fazendo constar do seu parecer as informações complementares que julgar necessárias ou úteis à deliberação da assembléia-geral; III - opinar sobre as propostas dos órgãos da administração, a serem submetidas à assembléia-geral, relativas a modificação do capital social, emissão de debêntures ou bônus de subscrição, planos de investimento ou orçamentos de capital, distribuição de dividendos, transformação, incorporação, fusão ou cisão; IV - denunciar aos órgãos de administração, e se estes não tomarem as providências necessárias para a proteção dos interesses da companhia, à assembléiageral, os erros, fraudes ou crimes que descobrirem, e sugerir providências úteis a companhia; IV - denunciar, por qualquer de seus membros, aos órgãos de administração e, se estes não tomarem as providências necessárias para a proteção dos interesses da companhia, à assembléia-geral, os erros, fraudes ou crimes que descobrirem, e sugerir providências úteis à companhia; V - convocar a assembléia-geral ordinária, se os 
A vontade da sociedade anônima é formada e exteriorizada a partir da relação entre os órgãos previstos acima.

\subsubsection{Histórico da estrutura administrativa}

A Companhia das Índias Orientais, primeira sociedade anônima que se tem notícia, era formada por "câmaras sediadas em várias cidades, com atribuições amplas para armar navios, construí-los e explorar expedições marítimas, que enviavam delegados à assembleia composta de dezessete representantes (...)" ${ }^{, 54}$. Esse era o órgão soberano da companhia, que tinha poderes para, inclusive, decidir sobre a distribuição de dividendos a seu exclusivo critério, além do fato de inexistir obrigação de prestação de contas naquela época.

LAmy Filho e Bulhões Pedreira ensinam que a concepção de acionistas e administradores que temos hoje foi iniciada na França na segunda metade do Século $\mathrm{XVII}^{55}$.

A relação entre acionistas e administradores foi idealizada e baseada no modelo de Estado democrático, equiparando-se o povo à camada de acionistas, como detentores do poder, e os mandatários políticos aos administradores, como representantes dos primeiros. 56

órgãos da administração retardarem por mais de 1 (um) mês essa convocação, e a extraordinária, sempre que ocorrerem motivos graves ou urgentes, incluindo na agenda das assembléias as matérias que considerarem necessárias; VI - analisar, ao menos trimestralmente, o balancete e demais demonstrações financeiras elaboradas periodicamente pela companhia; VII - examinar as demonstrações financeiras do exercício social e sobre elas opinar; VIII - exercer essas atribuições, durante a liquidação, tendo em vista as disposições especiais que a regulam."

53 Art. 160 da LSA: "As normas desta Seção aplicam-se aos membros de quaisquer órgãos, criados pelo estatuto, com funções técnicas ou destinados a aconselhar os administradores."

${ }^{54}$ BULHÕES PEDREIRA, José Luiz; LAMY FILHO, Alfredo. In Direito das Companhias. v. I. Rio de Janeiro: Forense, 2010, p. 777.

55 BULHÕES PEDREIRA, José Luiz; LAMY FILHO, Alfredo. In Direito das Companhias. v. I. Rio de Janeiro: Forense, 2010, p. 778.

56 “As sociedades anônimas foram originalmente concebidas nos moldes de um Estado democrático, segundo os dogmas da Revolução Francesa, de forma que todo o poder emanaria do acionista e em seu nome deveria ser exercido. Em tal concepção, os dirigentes não passariam de mandatários dos acionistas, por eles nomeados e demitidos a qualquer tempo. Assim, os dirigentes executivos das companhias não deteriam poderes próprios, agindo sempre em nome e por conta dos acionistas, cuja reunião em assembleia geral encarnaria a soberania societária." (EIZIRIK, Nelson. Acordo de acionistas regulando o exercício do poder 
O primeiro diploma que formalizou os administradores como mandatários dos acionistas, ainda sem qualquer menção à assembleia geral, foi o francês (i.e., Código do Comércio de 1807), o qual previa prazo mandato para os administradores, bem como diversas outras especifidades de sua função (destiuição, remuneração etc.). Também francesa foi a primeira lei a regulamentar a estrutura societária com a assembleia geral, a administração e o conselho de fiscal (1867) ${ }^{57}$

No Brasil, o Código Comercial de 1850 não tinha qualquer previsão sobre a assembleia geral, que passou a ser regulamentada apenas a partir de 1882.

Segundo Lamy Filho e Bulhões PedreirA, o Decreto-lei 2.627, de 1940 não trouxe grandes modificações à estrutura administrativa anterior ${ }^{58}$. Depois da recepção fática do conselho de administração, a LSA foi o diploma seguinte a regulamentar a estrutura administrativa societária que hoje conhecemos.

\subsubsection{A teoria organicista}

Após muito embate entre os doutrinadores sobre o funcionamento das sociedades no âmbito externo, prevaleceu o entendimento da teoria organicista ${ }^{59}$, segundo a qual a pessoa jurídica ${ }^{60}$ exterioriza sua vontade por meio de seus órgãos internos.

de controle. Interpretação dos $\$ 8^{\circ}$ e $9^{\circ}$ do art. 118 da Lei das S.A.. In Estudos de Direito Empresarial. São Paulo: Saraiva, 2010, pp. 30-31)

57 “(...) A assembleia geral de acionistas era o órgão supremo, pois nomeava os administradores e membros do conselho de fiscalização, tomava anualmente contas dos administradores e podia destituí-los; e os administradores eram considerados mandatários dos acionistas.” (BULHÕES PEDREIRA, José Luiz; LAMY FILHO, Alfredo. In Direito das Companhias. v. I. Rio de Janeiro: Forense, 2010, p. 778)

58 “(...) mas a partir da década de 1950 difundiu-se no País, por influência, principalmente, das corporations norte-americanas, da adoção de dois órgãos administrativos - Conselho de Administração e diretores - em vez de apenas diretores. Para essa prática contribuiu a legislação federal: a lei n. 2.004, de 03.10.1953, ao regular a criação da Petrobrás, como sociedade de economia mista, estabeleceu (no art. 19) que 'a sociedade será dirigida por um Conselho de Administração, com funções deliberativas e uma Diretoria Executiva (...)" (BULHÕES PEDREIRA, José Luiz e LAMY FILHO, Alfredo. In Direito das Companhias. v. I. Rio de Janeiro: Forense, 2010, p. 791)

59 (i) “(...) desde a edição do Decreto-lei no 2.627/1940, adotou-se a teoria organicista da administração, prevalecendo o entendimento doutrinário de que o vínculo existente entre o administrador e a sociedade é baseado na representação orgânica. (...) É importante, ainda, destacar que a condição de administrador decorre não de um contrato de representação com a sociedade, mas do ato jurídico unilateral de nomeação, mediante o qual the são atribuídos determinados poderes e deveres que o qualificam como órgão social. Embora a eficácia da nomeação esteja condicionada à aceitação do cargo por parte do administrador, nem por tal motivo a sua relação com a sociedade pode ser considerada contratual, já que a aceitação é mera condição de eficácia do ato jurídico unilateral de nomeação.” (PARENTE, Flávia. O dever de diligência dos 
Cada um destes órgãos internos ${ }^{61}$ representam centros de imputação de poderesdeveres específicos ${ }^{62}$. VERÇOSA ensina que:

(...) O órgão máximo, no qual se localiza o poder deliberativo da sociedade, é a assembleia-geral ou reunião de sócios. Em segundo lugar vêm o órgão ou os órgãos administrativos, conforme a sociedade seja constituída dentro do sistema unitário ou dual de administração (...). Outros órgãos podem existir, exigidos por determinação legal ou criados pelo ato constitutivo, como é o caso do conselho fiscal e dos conselhos consultivos. ${ }^{63}$

Pertinentes também os apontamentos de ADAMEK sobre o tema:

administradores de sociedades anônimas. Rio de Janeiro: Renovar, 2005, pp. 30-31). (ii) Também neste sentido ORLANDO GOMES: "Está evidentemente superada a teoria que qualifica esse vínculo como uma relação jurídica informada pelo contrato de mandato. Prevalece atualmente o entendimento de que é uma relação sobre a base da representação orgânica (...)." (GOMES, Orlando. Responsabilidade dos administradores de sociedades por ações. In Revista de Direito Mercantil, Industrial, Econômico e Financeiro. $\mathrm{n}^{\circ}$ 8, p. 11, apud, EIZIRIK, Nelson; GAAL, Ariádna B.; PARENTE, Flávia; HENRIQUES, Marcus de Freitas. Mercado de Capitais. Regime Jurídico. $3^{\text {a }}$ ed. ver. e ampl. Rio de Janeiro: Renovar, 2011, p. 493). (iii) Para ADAMEK: "atualmente, o entendimento majoritário (...) é de que a relação entre o administrador e a companhia qualifica-se como contrato de administração sui generis." (VON ADAMEK, Marcelo Vieira. Responsabilidade civil dos administradores de S/A e as ações correlatas. São Paulo: Saraiva, 2009, p. 48). BRITO CORREA define o contrato de administração como “(...) aquele pelo qual uma pessoa se obriga, mediante remuneração ou sem ela, a prestar a sua atividade de gestão e representação orgânica da sociedade anônima, sob a orientação da coletividade dos acionistas e sob a fiscalização do conselho fiscal" (CORREIA, Luís Brito. Os administradores de sociedades anônimas. Coimbra: Almedina, 1993, p. 740, apud, VON ADAMEK, Marcelo Vieira. Responsabilidade civil dos administradores de S/A e as ações correlatas. São Paulo: Saraiva, 2009, p. 48".

60 De acordo com FRANCO e SZTAJN: "Francesco Galgano, ao tratar da questão [personificação das anônimas], de maneira jocosa, chegou a dizer que o homem superou o Criador porque conseguiu criar uma pessoa imortal" (FRANCO, Vera Helena de Melo; SZTAJN, Rachel. Direito Empresarial II: sociedade anônima, mercado de valores mobiliários. $2^{a}$ ed. ver. atual. e ampl. São Paulo: Revista dos Tribunais, 2009, p. 193)

61 "Os conceitos de órgão e organização foram formados pela biologia a partir da observação do organismo, ou indivíduo biológico, que é um conjunto de células, tecidos e órgãos integrados funcionalmente. Analisado como objeto composto, o organismo é um sistema, ou conjunto de elementos interligados por relações, e em maior grau de abstração organizar é criar um sistema, e órgão é o subconjunto funcional de um sistema." (BULHÕES PEDREIRA, José Luiz e LAMY FILHO, Alfredo. In Direito das Companhias. v. I. Rio de Janeiro: Forense, 2010, p. 775)

62 "Nunca é demais reforçar que os órgãos da companhia não gozam de personalidade jurídica (atribuída pelo legislador apenas à própria sociedade), mesmo que gozem de autonomia funcional bastante ampla." (VON ADAMEK, Marcelo Vieira. Responsabilidade civil dos administradores de S/A e as ações correlatas. São Paulo: Saraiva, 2009, p. 413)

${ }^{63}$ VERÇOSA, Haroldo Malheiros Duclerc. Curso de direito comercial. v. 3. $2^{\mathrm{a}}$ ed. São Paulo: Malheiros, 2011, pp.186-187. Também neste sentido as lições de FRANCO e SzTAJN: "Inexiste aqui a relação obrigacional entre duas pessoas. O agente que manifesta a vontade é parte integrante do dominus negocii, isto é de quem se obriga. No caso, a pessoa jurídica. O órgão, assim, é o meio pelo qual a sociedade realiza sua atividade jurídica. É elemento interno da sua sociedade, pertence à sua estrutura." (FRANCO, Vera Helena de Melo; SZTAJN, Rachel. Direito Empresarial II: sociedade anônima, mercado de valores mobiliários. $2^{\mathrm{a}}$ ed. ver. atual. e ampl. São Paulo: Revista dos Tribunais, 2009, p. 177) 
Apesar de a pessoa jurídica constituir ente fisicamente abstrato, é juridicamente real e, diversamente dos incapazes, possui vontade própria, que não carece ser suprida por terceiros. O órgão é parte integrante da pessoa jurídica, e a vontade por ele exteriorizada é imputada diretamente a esta, e não em substituição de sua vontade. $^{64}$

\subsubsection{Hierarquia entre órgãos}

A partir da construção da teoria organicista, inquire-se se haveria hierarquia entre os órgãos no processo de formação da vontade social.

Uma análise sistemática da LSA nos permite concluir que foi atribuída uma hierarquia funcional relativa entre os órgãos da sociedade anônima ${ }^{65}$. Isso porque, no primeiro plano, temos a assembleia geral de acionistas ${ }^{66}$ como o órgão máximo capaz de eleger os membros do conselho de administração, criar e modificar o estatuto social da companhia, deliberar sobre assuntos de relevância extraordinária ${ }^{67}$, e anualmente aprovar as contas e demonstrações financeiras da sociedade.

${ }^{64}$ VON ADAMEK, Marcelo Vieira. Responsabilidade civil dos administradores de S/A e as ações correlatas. São Paulo: Saraiva, 2009, p. 36.

${ }^{65}$ LAMY FILHO e BULHõES PEDREIRA afirmam que "As competências dos órgãos sociais definidas pela lei evidenciam que a estrutura da companhia é hierarquizada: (i) a assembleia geral é o órgão supremo, "tem poderes para decidir todos os negócios relativos ao objeto social' (art. 121), (...); e (ii) o Conselho de Administração define a orientação geral dos negócios da companhia (...). Por conseguinte, a assembleia geral exerce o poder hierárquico sobre o Conselho de Administração e o Conselho Fiscal, e o Conselho de Administração exerce poder sobre os diretores." (BULHÕES PEDREIRA, José Luiz e LAMY FILHO, Alfredo. In Direito das Companhias. v. I. Rio de Janeiro: Forense, 2010, p. 805).

${ }^{66}$ (i) "O princípio da deliberação da assembleia geral pelo voto majoritário contribuiu para que alguns teóricos construíssem um modelo utópico de companhias - extrapolando para esta os princípios políticos do sufrágio universal e da igualdade de todos perante a lei - que nada tem a ver com o voto do acionista e os direitos e garantias que lhe devem ser assegurados. (...) Uma assembleia-geral (...) é uma reunião de 'sacos de dinheiro que votam', e não uma festa cívica.” (BULHÕES PEDREIRA, José Luiz e LAMY FILHO, Alfredo. In Direito das Companhias. v. I. Rio de Janeiro: Forense, 2010, p. 779). (ii) "É, portanto, como dizem os antigos, o órgão soberano da sociedade, tendo poderes para decidir amplamente e até, em última instância, tudo o que se refira à sociedade, não obstante, como veremos mais adiante, atribuições outras e poderes tenham sido conferidos aos demais órgãos que integram a administração em geral da sociedade." (BULGARELLI, Waldirio: Manual das Sociedades Anônimas. 6 a . ed. São Paulo: Atlas, 1991, p. 150). (iii) “(...) a assembleia geral é um órgão interno da companhia, já que não tem poderes de representação. Suas decisões são executadas pela diretoria (art. 144)." (CARVALHOSA, Modesto. Comentários à lei das sociedades anônimas. $5^{\text {a }}$ ed. São Paulo: Saraiva, 2011. vol. 2, p. 770).

${ }^{67}$ (i) "Apesar de atribuir à assembleia o papel central na hierarquia orgânica de tomada de decisões, o legislador reconheceu a tendência ao deslocamento do centro de tomada de decisões do órgão assemblear para os órgãos da administração, como expressão de um movimento de surgimento das chamadas macroempresas e da sofisticação de suas estruturas." (PATELLA, Laura Amaral; BORES, Leandro Vilarinho; BERNARDES, Lucas Petri; AZEVEDO, Luís André Negrelli de Moura. Deveres Fiduciários dos Administradores. Vinculação dos Administradores. In Mercado de Capitais Brasileiro: Doutrina, Cases e Materials. São Paulo: Quartier Latin, 2012, p. 227). (ii) “(...) com efeito, é praticamente um consenso que a assembleia geral dos acionistas tranformou-se num sofisticado exercício de ilusão popular do capitalismo. O 


\section{No segundo plano, o conselho de administração ${ }^{68}$ concentraria o poder de eleger os}

diretores e supervisionar e instruir a condução dos assuntos de relevância ordinária $^{69}$ da sociedade anônima ${ }^{70}$.

fulcro do poder na sociedade anônima concentrou-se na administração ou nas mãos de um pequeno grupo de acionistas controladores, usualmente organizados através de acordos de acionistas." (EIZIRIK, Nelson. Acordo de acionistas regulando o exercício do poder de controle. Interpretação dos $\$ 8^{\circ}$ e $9^{\circ}$ do art. $118 \mathrm{da}$ Lei das S.A.. In Estudos de Direito Empresarial. São Paulo: Saraiva, 2010, pp. 30-31)

${ }^{68}$ (i) "Informam Garrigues \& Uria (1976, v. II, p. 9 s segs.) que tradicionalmente dois sistemas se distinguem na matéria: o 'francês clássico', que estabelecia um órgão unitário de administração (...) e o sistema germânico, que separa as funções administrativas e representativas (....)" (BULHÕES PEDREIRA, José Luiz; LAMY FILHO, Alfredo. In Direito das Companhias. v. I. Rio de Janeiro: Forense, 2010, p. 793); (ii) VERÇOSA comenta que: "O conselho de administração, por decisão do legislador, é um órgão de deliberação colegiada, isto é, funciona tão somente a partir das propostas apresentadas e aprovadas em reunião devidamente convocada e instalada, relativamente às matérias de sua competência. (...)" (VERÇOSA, Haroldo Malheiros Duclerc. Curso de direito comercial. v. 3. $2^{a}$ ed. São Paulo: Malheiros, 2011, p. 412); e (iii) Para CARVALHOSA: "A importância desse órgão também ressurge quando há dissídio entre controladores e minoritários. Neste caso, a representação proporcional assegurada pelo art. 141 dá aos acionistas dissidentes a oportunidade de imprimirem realidade aos poderes formais do Conselho e controle da legitimidade dos atos dos diretores. A prerrogativa que têm os conselheiros de individualmente diligenciar informações junto aos diretores, para o efeito de instruir as deliberações do Conselho restaura ainda mais esse poder de fiscalização e até de condução efetiva da política empresarial." (CARVALHOSA, Modesto. Comentários à lei das sociedades anônimas. $5^{\mathrm{a}}$ ed. São Paulo: Saraiva, 2011. vol. 3, pp. 19-20). Afirma ainda que: "Diferentemente do que ocorre com os diretores, o exercício dos encargos legais e estatutários dos conselheiros faz-se pela maioria de seus integrantes. Os conselheiros, ao participarem coletivamente da formação da vontade do respectivo órgão, têm responsabilidade colegiada." (CARVALHOSA, Modesto. Comentários à lei das sociedades anônimas. $5^{\text {a }}$ ed. São Paulo: Saraiva, 2011. vol. 3, p. 358)

${ }^{69}$ Para CALIXTO SALOMÃo, o conselho de administração representa um "instrumento de consolidação do poder do controlador, como resulta evidente da simples leitura do art. 142 da lei societária brasileira, o Conselho de Administração concentra as mais relevantes competências em matéria de administração da sociedade. Sendo um órgão totalmente dominado pelos controladores, a atribuição de competências administrativas a esse órgão tem um efeito muito peculiar sobre as estruturas societárias, amplamente favorável ao controlador. De um lado afasta as decisões mais importantes sobre a estratégia empresarial da turbulência das assembleias, fazendo com que o pequeno investidor não tenha vez, voz e sequer informação sobre a maioria dos negócios da sociedade - e isso continuará ocorrendo, pois os direitos de eleição de conselheiros em separado aplicam-se somente às minorias institucionais. De outro lado, afasta completamente as decisões da diretoria, que passa a ser mera gerência executiva das decisões do controlador" (SAlOMÃO FILHO, Calixto. O novo direito societário, $4^{\text {a }}$. ed., São Paulo: Malheiros, 2011, p. 87). No mesmo sentido ADAMEK: "Na estrutura orgânica da companhia, o conselho de administração insere-se entre a assembleia geral e a diretoria (...) e, na medida em que o órgão é dominado pela maioria, é possível afirmar que se trata, realmente, de instância societária de consolidação do poder do controlador. Justifica-se essa afirmação quando se constata que o conselho exerce atribuições que, de ordinário, competiriam privativamente à assembleia geral (v.g. LSA, art. 142, IV, VIII e IX), afastando ainda mais os acionistas da tomada de decisões estratégicas da empresa e colocando os diretores na posição de executores das deliberações do conselho" (VON ADAMEK, Marcelo Vieira. Responsabilidade civil dos administradores de S/A e as ações correlatas. São Paulo: Saraiva, 2009, p. 21)

${ }^{70}$ (i) “(...) torna-se irrecusável reconhecer que nas matérias referentes à condução dos negócios sociais, a competência dos órgãos administrativos (o Conselho de Administração, quando houver, e hierarquicamente abaixo dele, a Diretoria) é residual em relação à competência da assembleia. Assim, malgrado as disposições do artigo 142, que enumera as atribuições do Conselho de Administração, não pode esse órgão fixar orientação geral dos negócios da companhia em desacordo com as instruções emanadas da assembleia (...)" (TEPPEDINO, Ricardo. In Direito das Companhias. Vol. I. Rio de Janeiro: Forense, 2010, p. 881); (ii) Também nesse sentido a lição de EIZIRIK: "A noção de hierarquia dos órgãos na companhia decorre da concepção da 'democracia societária'. Os acionistas são equiparados aos eleitores, os membros eleitos dos órgãos administrativos aos seus representantes, as solicitações de procurações às campanhas eleitorais e o estatuto social à Constituição. A partir dessa perspectiva, os acionistas têm direitos essenciais, individuais, 
Em planos distintos, teríamos, ainda, (i) a diretoria, responsável pela condução de todos os assuntos de interesse da companhia, inclusive com poderes de representação ${ }^{71}$ da sociedade anônina e competência residual em relação a quaisquer matérias que não sejam de atribuição de outros órgãos; (ii) o conselho fiscal ${ }^{72}$, cuja função precípua é a de fiscalizar os atos da administração; e (iii) os órgãos técnicos e consultivos criados pelo estatuto social para assessorar a administração em assuntos específicos, tal qual auditoria, recursos humanos, remuneração etc.

Notamos que tanto a lei quanto o estatuto ${ }^{73}$ atribuem competências privativas ou complementares aos órgãos da sociedade anônima, as quais não podem (como veremos adiante no subcapítulo 5.3) ser delegadas a outro órgão. ${ }^{74}$ Dessa forma, a hierarquia entre os órgãos deve ser entendida como funcional e relativa à medida que um órgão é capaz de eleger membros de outro órgão, instruir e até fiscalizar sua atuação - estando, assim, em

comparáveis aos dos cidadãos no regime democrático, e os administradores são responsáveis pela conservação e proteção de tais direitos.” (EIZIRIK, Nelson. A Lei das S.A. Comentada. Volume II - Arts. 121 a 188. São Paulo: Quartier Latin, 2011, p. 16)

${ }^{71}$ CARVAlHOSA ensina que: "O Conselho de Administração é um órgão formalmente decisório tanto quanto o é a diretoria (art. 143). A diferença é que aquele tem competência decisória apenas interna, não podendo representar organicamente a companhia perante terceiros." (CARVALHOSA, Modesto. Comentários à lei das sociedades anônimas. v. 3. $5^{\text {a }}$ ed. São Paulo: Saraiva, 2011, p. 11)

72 “O conselho fiscal das companhias é um órgão societário já existente na estrutura daquelas de longa data. (...) $\mathrm{Na}$ lei atual é obrigatório, mas de funcionamento não permanente, exceto quando assim previsto em leis especiais ou pelo estatuto. (...) Sua atribuição fundamental seria a de fiscalização dos administradores no exercício das atividades destes à frente da companhia (...)" (VON ADAMEK, Marcelo Vieira. Responsabilidade civil dos administradores de S/A e as ações correlatas. São Paulo: Saraiva, 2009, p. 504).

${ }^{73}$ EIZIRIK ensina que: "O estatuto social, como lei interna da companhia, pode criar outras hipóteses de deliberação privativa da assembleia geral, conforme o interesse da companhia. (...) Caso o estatuto social proceda dessa forma, atribuindo a determinado órgão social a competência sobre uma matéria específica, esta reserva de competência deve ser necessariamente observada pelos acionistas, uma vez que as normas estatutárias possuem força de direito inerente ao agrupamento, isto é, têm natureza obrigatória, devendo ser permanentemente respeitadas por todos os acionistas." (EIZIRIK, Nelson. A Lei das S.A. Comentada. Volume II - Arts. 121 a 188. São Paulo: Quartier Latin, 2011, p. 22). Concordamos parcialmente com o entendimento acima, tendo em vista o fato de que o estatuto social (e o acordo de acionistas, como se verá adiante) não poderá versar sobre matérias de competência privativa de outros órgãos.

74 (i) "De fato, apesar de cada órgão social possuir atribuições privativas - e, por consequência, indelegáveis -, eles não se posicionam paralelamente em um mesmo nível, mas, ao reverso, estruturam-se de forma hierárquica. Com isso, não quer sinalizar propriamente que um órgão esteja submetido a outro, pois cada qual tem, pela lei, funções próprias: não podem os acionistas ou os estatutos redistribuí-las entre os órgãos sociais ou acometerem-nas a terceiros; quer-se tão somente sinalizar que há órgãos que se colocam em posição superior, pois regulam a eleição dos cargos de outros órgãos; e, nos limites da lei, tomam decisões que vão impor determinados comportamentos aos demais." (VON ADAMEK, Marcelo Vieira. Responsabilidade civil dos administradores de S/A e as ações correlatas. São Paulo: Saraiva, 2009, p. 16); (ii) LAMY FILHO e BULHÕES PEDREIRA falam em subordinação e necessidade cumprir as determinações recebidas: “A estrutura da companhia, como a de qualquer outro grupo social em que ação dos membros é orientada para objetivo ou fim comum, é hierarquizada: (...) que compreende relações de subordinação - os ocupantes de alguns órgãos ou cargos exercem poder sobre os de outros, que têm o dever de cumprir as ordens recebidas." (BULHÕ̃S PEDREIRA, José Luiz; LAMY FILHO, Alfredo. In Direito das Companhias. v. I. Rio de Janeiro: Forense, 2010, p. 776) 
posição hierarquicamente superior -, mas não por esse motivo substituí-lo em suas funções. 


\section{O INTERESSE SOCIAL}

A importância deste capítulo justifica-se no fato de a LSA ter atribuído um dever de observância do interesse da companhia às duas fontes de poder (do acionista, nos artigos $115^{75}$ e $116^{76}$; e gerencial, no artigo $154^{77}$ ) analisadas neste trabalho ${ }^{78}$. Nesse sentido, somente após o entendimento do conceito de interesse social é que teremos condições de analisar se vincular o poder gerencial ao poder do acionista representaria o melhor interesse da companhia.

Para tal fim, analisaremos sucintamente, a seguir, as principais escolas doutrinárias sobre o interesse social e, ao final deste capítulo, teceremos nossas conclusões acerca do tema (com a ciência da dificuldade do tema ${ }^{79}$ ).

\subsection{Teorias contratualistas}

Em última análise, essa escola contempla o interesse social como o interesse do grupo de sócios, sem que a este seja agregado fatores externos (exceto pelo interesse dos sócios futuros que é considerado por alguns doutrinadores contratualistas), como interesses de trabalhadores, fornecedores, clientes etc. (os denominados stakeholders).

\footnotetext{
75 Art. 115 da LSA, caput: "O acionista deve exercer o direito a voto no interesse da companhia; considerarse-á abusivo o voto exercido com o fim de causar dano à companhia ou a outros acionistas, ou de obter, para si ou para outrem, vantagem a que não faz jus e de que resulte, ou possa resultar, prejuízo para a companhia ou para outros acionistas."

${ }^{76}$ Art. 116 da LSA, parágrafo único: "O acionista controlador deve usar o poder com o fim de fazer a companhia realizar o seu objeto e cumprir sua função social, e tem deveres e responsabilidades para com os demais acionistas da empresa, os que nela trabalham e para com a comunidade em que atua, cujos direitos e interesses deve lealmente respeitar e atender."

77 Art. 154 da LSA, caput: "O administrador deve exercer as atribuições que a lei e o estatuto lhe conferem para lograr os fins e no interesse da companhia, satisfeitas as exigências do bem público e da função social da empresa."

78 "Tanto no que concerne ao exercício do direito de voto pelos acionistas [art. 115], quanto no tocante à atividade dos órgãos da administração [art. 154], a Lei $n^{\circ}$ 6.404/1976 tratou de registrar o respeito e a necessária vinculação aos fins e aos interesses da companhia, principais balizadores da tomada de decisões no âmbito das sociedades." (PATELLA, Laura Amaral; BORES, Leandro Vilarinho; BERNARDES, Lucas Petri; AZEVEDO, Luís André Negrelli de Moura. Deveres Fiduciários dos Administradores. Vinculação dos Administradores. In Mercado de Capitais Brasileiro: Doutrina, Cases e Materials. São Paulo: Quartier Latin, 2012, p. 227).

79 "São bem conhecidas as dificuldades em definir interesse social, o que tornaria absolutamente incerta a aplicação de uma regra baseada na comparação entre o comportamento de alguém e o interesse social." (SALOMÃO FILHO, Calixto. O Novo Direito Societário. $4^{\mathrm{a}}$ ed. São Paulo: Malheiros, 2011, p. 64)
} 
Em outras palavras, o interesse social não representa a soma do interesse individual de cada um dos sócios, tampouco pode ser reduzido ao interesse de cada indivíduo, mas representa a realização do escopo social (lato sensu) em si, composto do objeto social em si (atividade-meio) e de sua finalidade lucrativa (atividade-fim) ${ }^{80}$.

\title{
3.1.1. Escola clássica
}

\author{
Na clássica lição de ASCARELLI:
}

O voto é concedido ao sócio para a tutela de seu interesse como sócio; encontra a sua justificação e seu limite na comunhão de interesses; só no limite de seu interesse como sócio que os acionistas são (até com sacrifício de seu interesse extrassocial frente ao interesse social) sujeitos à deliberação da maioria. ${ }^{81}$

Do ensinamento acima se depreende que a escola clássica não vislumbra a possibilidade de se considerar outros interesses que não os dos sócios, tampouco o de sócios futuros. Todavia, importante denotar que não seriam quaisquer interesses dos sócios atuais $^{82}$, mas apenas e tão somente aqueles inerentes à sua condição de sócio ${ }^{83}$, excluindo, portanto, seus interesses extra-societários ${ }^{84}$.

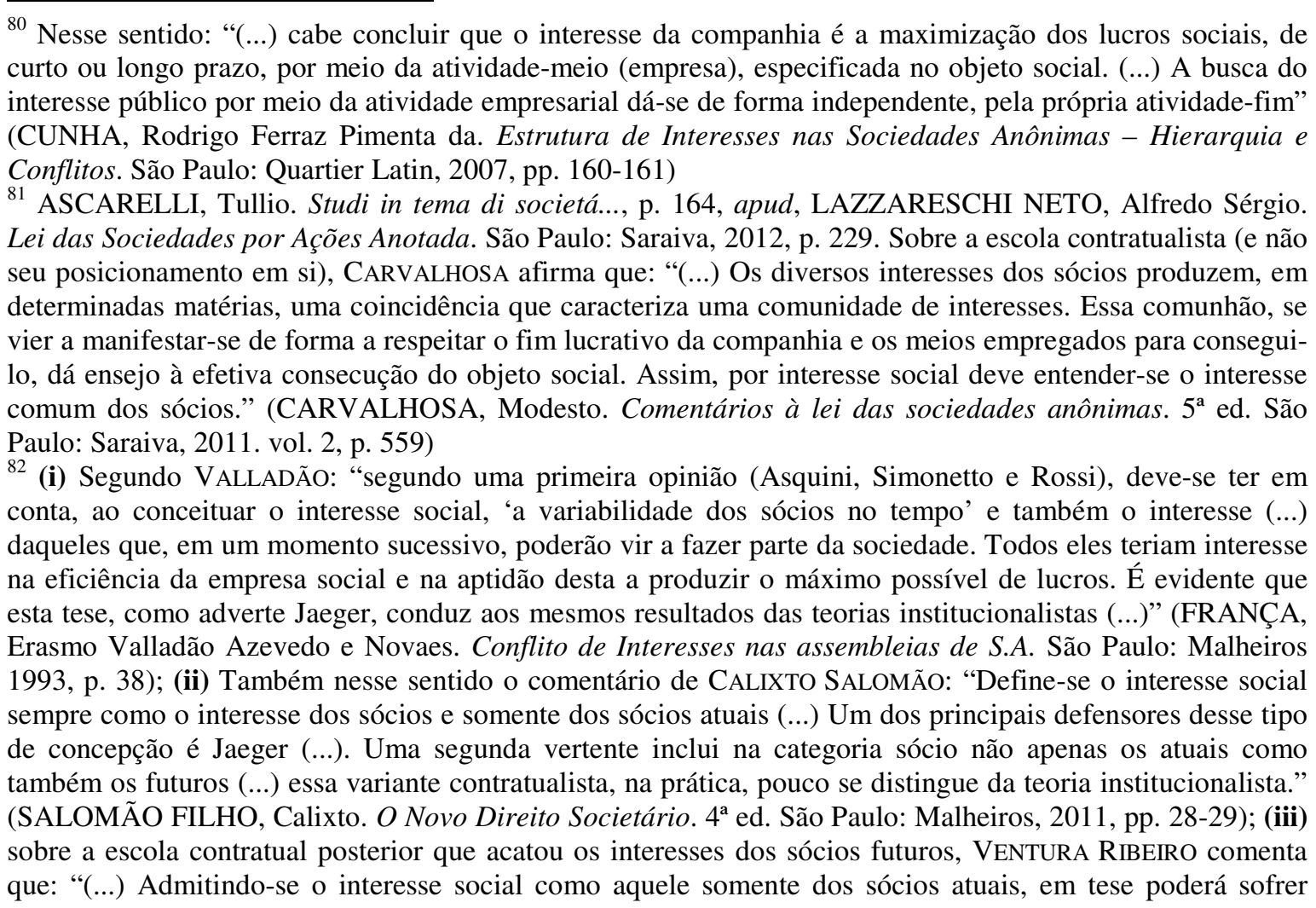


Também adeptos da teoria contratualista, interessante compartilhar as opiniões de EIZIRIK e VALLADÃO, respectivamente:

O interesse social não é, pois, a somatória dos interesses individuais de cada acionista, mas a transcendência desses mesmos interesses por um interesse comum a todos, definido no objetivo empresarial da companhia e nos seus fins sociais, qual seja, a sua prosperidade, representada pela contínua criação de valor.

Pode-se, concluir, assim, que o interesse da companhia (ou interesse social stricto sensu), na Lei 6.404, constitui um conceito típico e específico, consistente no interesse comum dos sócios à realização do escopo social, abrangendo, portanto, qualquer

alteração (...). Por outro lado, estando abrangidos no interesse social também os interesses dos sócios futuros, o interesse social tende a ser abstrato, imutável e certo. (...) Neste sentido, a teoria [do interesse dos sócios atuais e futuros] guarda identidade com a tese institucionalista da Unternehmen an Sich." (RIBEIRO, Renato Ventura. Direito de Voto nas Sociedades Anônimas. São Paulo: Quartier Latin, 2009, pp. 115-116)

${ }^{83}$ VALLADÃo ensina que “(...) parte prevalente da doutrina acrescenta que o interesse social é o interesse comum dos sócios enquanto sócios (...). O interesse social, assim concebido, não se identifica com outros interesses comuns dos sócios, nem representa uma somatória dos seus direitos individuais, mas é um interesse ex causa societatis, decorrente do seu status socii. Todos os outros interesses dos sócios, que não este interesse comum, típico e específico, são considerados, pois, estranhos à sociedade (...)" (FRANÇA, Erasmo Valladão Azevedo e Novaes. Conflito de Interesses nas assembleias de S.A. São Paulo: Malheiros, São Paulo: 1993, p. 37)

${ }^{84}$ O Colegiado da CVM, embora ressaltando sempre a prevalência do interesse social no voto do acionista, entende que os não controladores podem perseguir interesses individuais no exercício do voto, sem que tal conduta possa ser considerada abusiva: "Se o voto não puder violar interesse da companhia, é lícito ao acionista exercê-lo no seu próprio interesse (omissis) enquanto os administradores representam os interesses da companhia, sem poder privilegiar um acionista, um grupo ou uma espécie de acionistas (art. 154, caput, e, especialmente, seu $\S 1^{\circ}$ ), os acionistas defendem interesse próprio, que muitas vezes são contrapostos aos dos demais acionistas. Nesses casos, se a questão tratar de direitos dos acionistas em impacto nas atividades da companhia, é lícito ao acionista votar no interesse de sua espécie ou classe, sem levar em consideração o interesse de outra espécie ou classe (desde que não vise causar dano para outros acionistas ou obter vantagem a que não faz jus com prejuízo para a companhia ou para acionistas). Dentro de uma mesma espécie ou classe de ações, o acionista pode votar, observadas essas mesmas limitações, de acordo com seu interesse individual" (Colegiado da CVM, PAS CVM RJ 12/01, Rel. Diretor Pedro Oliva Marcílio de Sousa, j. em 121-2006, apud, LAZZARESCHI NETO, Alfredo Sérgio. Lei das Sociedades por Ações Anotada. São Paulo: Saraiva, 2012, p. 168)

${ }^{85}$ EIZIRIK, Nelson. A Lei das S.A. Comentada. Volume II - Arts. 121 a 188. São Paulo: Quartier Latin, 2011, p. 510. Também nesse sentido: (i) BULGARELLI: "sob um aspecto geral, o interesse da sociedade (e se quiserem o interesse também da empresa) e o interesse do acionista, considerados uti singuli, ou da soma dos acionistas, são os mesmos: a obtenção dos lucros da sociedade, por intermédio da empresa, e sua distribuição, ou, visto pelo ângulo do acionista, a sua participação nos lucros." (BULGARELLI, Waldirio. A proteção das minorias na sociedade anônima, p. 350, apud, CUNHA, Rodrigo Ferraz Pimenta da. Estrutura de Interesses nas Sociedades Anônimas - Hierarquia e Conflitos. São Paulo: Quartier Latin, 2007, pp., 123-124). (ii) "Posição similar é encontrada nos Principles of the American Law Institute (1994, p. 20.1), que recomendam que a companhia deve 'conduzir os negócios em vista de aumentar o lucro empresarial e o ganho dos acionistas'." (SAMPAIO CAMPOS, Luiz Antonio. In BULHÕES PEDREIRA, José Luiz e LAMY FILHO, Alfredo (Coord.). Direito das Companhias. Vol. I. Rio de Janeiro: Forense, 2010, p. 1114) 
interesse que diga respeito à causa do contrato de sociedade, seja o interesse à melhor eficiência da empresa, seja à maximização dos lucros, seja à maximização dos dividendos. ${ }^{86}$

Segundo LAMY REGO, os próprios autores do projeto da LSA seriam seguidores da corrente contratualista:

A LSA adotou essa corrente contratualista. Como afirmam José Luiz Bulhões Pedreira e Alfredo Lamy Filho (1996, v. II, p. 238), o interesse da companhia não é um interesse superior, estranho e acima da vontade comum dos sócios, ou um interesse da empresa em si, a ser descoberto pelo juiz, e capaz de anular a deliberação social, mesmo unânime. $O$ voto deve, pois, ser exercido no interesse da companhia, identificado este como o interesse comum dos sócios ${ }^{87}$

\subsubsection{Escolas modernas: o shareholder primacy}

Dentre as diversas escolas modernas contratualistas, destacamos aquela desenvolvida nos Estados Unidos denominada "shareholder primacy" ou "shareholderoriented model ${ }^{, 88}$.

\footnotetext{
${ }^{86}$ FRANÇA, Erasmo Valladão Azevedo e Novaes. Conflito de Interesses nas assembleias de S.A. São Paulo: Malheiros: 1993, p. 62. VALLADÃO explica ainda que: "é evidente que a tutela do interesse coletivo dos investidores no mercado de capitais abrange não somente o interesse daqueles atuais como também dos futuros, que poderão vir a ser acionistas da sociedade." (FRANÇA, Erasmo Valladão Azevedo e Novaes. Conflito de Interesses nas assembleias de S.A. São Paulo: Malheiros: 1993, p. 49).

${ }^{87}$ LAMY REGO, Marcelo. In Direito das Companhias. Vol. I. Rio de Janeiro: Forense, 2010, p. 403.

${ }^{88}$ (i) "Não é de se estranhar, portanto, que o próprio Jaeger tenha revisto sua teoria 40 anos depois, para identificar o interesse social na perspectiva contratualista à obtenção de shareholder value, i.e., a maximização do valor de venda das ações do sócio. Essa perspectiva, dominante na prática societária americana e na doutrina daquele país, que, com base nela, chega a falar em final da história do direito societário, tem efeitos teóricos e práticos extremamente deletérios" (SALOMÃO FILHO, Calixto. O Novo Direito Societário. $4^{\mathrm{a}}$ ed. São Paulo: Malheiros, 2011, p. 31). CALIXTO SALOMÃo está fazendo referência ao trabalho de HANSMANN e KRAAKMAN (já mencionados anteriormente) (The End of History for Corporate Law. Georgetown Law Journal 89. 2001, pp. 439 e seguintes). (ii) HANSMANN e KRAAKMAN sustentam que há uma convergência ao modelo da prevalência dos interesses dos acionistas. Sustentam isso sob três perspectivas: (i) do ponto de vista lógico, os acionistas terão mais incentivos a maximizar o valor da companhia se seus interesses forem adequadamente protegidos; (ii) do ponto de vista paradigmático, já que as economias que adotaram a prevalência do interesse do acionista tiveram melhor performance do que as demais; e (iii) do ponto de vista competitivo, já que as companhias que adotaram a prevalência do interesse do acionista verificaram vantagens sobre as companhia que aderiram a outros modelos. (HANSMANN, Henry e KRAAKMAN, Reinier. The End of History for Corporate Law. Georgetown Law Journal 89. 2001, pp. 439 e seguintes, pp. 441-442). (iii) "The controllling shareholder has the capacity and all the right incentives to be the best monitor of his investment in the company (and the other shareholders free ride on his effort)." (URTIAGA, María Gutierrez; SAEZ, Maribel. Deconstructing Independent Directors. Working Paper No. 186/2012. January 2012, p. 14. Disponível in <http://ssrn.com/abstract=1986842>. Último acesso em 18.01.2014).
} 
Segundo tal escola ${ }^{89}$, a maneira mais eficiente ${ }^{90}$ de uma companhia funcionar e, inclusive, atender a interesses diversos dos acionistas (e, nos termos da LSA, cumprir com sua função social), é ter por objetivo a maximização do seu $\operatorname{lucro}^{91}$ ou riqueza $^{92}$.

Isso porque, do ponto de vista prático, o acionista é o último beneficiário do lucro auferido pela companhia ${ }^{93}$, já que pela regra de escrituração prevista na LSA (e, de certa forma, adotada pelos principais sistemas de direito societário no mundo), os lucros somente podem ser distribuídos depois de realizadas diversas deduções do resultado apurado ao final do exercício social, i.e., custos e despesas correntes que incluem salários

${ }^{89}$ Para fundamentar a importância e cada vez mais usual adoção do modelo do shareholder primacy, HANSMANN e KRAAKMAN, no trabalho de revisão que fizeram da obra inicial de 2001, citam o exemplo das mais lucrativas companhias chinesas, que embora formalmente adotem o modelo state-oriented, possuem forte participação privada, fazendo com que no fim do dia tais companhias acabem por na prática adotar o modelo da prevalência do interesse do acionista. Citam ainda que o próprio Estado chinês provavelmente preferirá retorno financeiro ao político, estimulando cada vez mais a adoção e persistência do modelo de primazia do acionista. (HANSMANN, Henry e KRAAKMAN, Reinier. Reflections on the end of history for corporate law. August 2011. Forthcoming in Abdul Rasheed and Toru Yoshikawa, Eds. Convergence Corporate Governance: Promise and Prospects. Palgrave-MacMillan 2012. Disponível in < http://ssrn.com/abstract=2095419> Último acesso em 18.01.2014). Nesta revisão, os autores afirmam que na prática a convergência dos sistemas de direito societário no mundo pode não ocorrer necessariamente na prevalência do acionista, mas em algo próximo a isso, reservando aos acionistas controladores ou administradores um pouco mais de discricionariedade do que prescrito pelo modelo.

${ }^{90}$ Segundo VERGUEIRO: "O que a história já demonstrou é que a valorização de outras categorias que não a do acionista acaba por destruir, ou ao menos dificultar, a participação da companhia dentro de um ciclo virtuoso de geração de riqueza, além de dificultar o desenvolvimento do mercado de valores mobiliários (...)" (VERGUEIRO, Carlos Eduardo. Acordo de Acionistas e a Governança das Companhias - São Paulo: Quartier Latin, 2010, p. 77)

${ }^{91}$ Sobre o sentido do termo lucro, CUNHA explica que: "É exatamente na noção de perseguição de lucro, mediante o desenvolvimento de atividade econômica, que se fundamenta o interesse social. (...) Mas qual seria a exata noção da palavra lucro? Conforme se depreende da interpretação sistemática e lexical de sua utilização no art. $2^{\mathrm{a}}$ da Lei das Sociedades Anônimas, o vocábulo deve ser interpretado em sentido lato, como sinônimo de aumento de riqueza, e não, como equivocadamente entende parte da doutrina, como distribuição aos acionistas dos ganhos decorrentes do exercício da atividade econômica, sobretudo na forma de dividendos. (...) Com o aumento da riqueza da companhia, o acionista é naturalmente beneficiado, já que há aumento imediato de seu patrimônio (...)." (CUNHA, Rodrigo Ferraz Pimenta da. Estrutura de Interesses nas Sociedades Anônimas - Hierarquia e Conflitos. São Paulo: Quartier Latin, 2007, p. 124)

92 "Segundo determinada corrente, dominante na doutrina norte-americana, os deveres fiduciários dos administradores dizem respeito apenas aos interesses dos acionistas, não devendo ser considerados outros interesses (shareholder primacy). Não se trata de reconhecer à companhia o papel de apenas contribuir para a maximização da riqueza dos acionistas (visão contratualista), mas sim de concluir que a melhor forma de determinar que os administradores conduzam a empresa no sentido de sua função social é a de estabelecer que estes devem visar à maximização da riqueza dos acionistas. O princípio é que, ao conferir-se diferentes deveres aos administradores, por vezes conflitantes, o monitoramento do cumprimento de sua função torna-se de difícil aplicação. Todas as decisões podem ser justificadas segundo um dos interesses conflitantes cuja defesa pelos administradores é admitida." (MUNHOZ, Eduardo Secchi. Quem deve comandar a companhia? Alocação do poder empresarial: sistema de freios e contrapesos. In Estudos em Homenagem a Modesto Carvalhosa. São Paulo: Saraiva, 2012. pp. 512)

${ }_{93}$ Segundo VERGUEIRO: "Olhando-se com detalhe, acionistas são os últimos a receberem o que lhes interessa em decorrência da atividade social. Para que o pagamento do dividendo ocorra é necessário que, anteriormente, remuneração de empregados, contraprestação de fornecedores, tributos e débitos com credores tenham sido quitados. (...) Uma análise meramente contábil, portanto, conseguirá evidenciar como a valorização do acionista se mostra como medida estratégica" (VERGUEIRO, Carlos Eduardo. Acordo de Acionistas e a Governança das Companhias - São Paulo: Quartier Latin, 2010 p. 76) 
de empregados e tributos incidentes sobre a operação, eventuais prejuízos acumulados (relacionados, por exemplo, a custos, despesas ou tributos incidentes tanto sobre a operação quanto sobre a renda devidos em exercícios anteriores), tributos sobre a renda, participações de empregados e administradores e reservas legal e estatutária) ${ }^{94}$.

Uma sociedade anônima lucrativa, em tese, contrataria mais (e demitiria menos) empregados, honraria seus compromissos com clientes, credores e fornecedores e desenvolveria a comunidade local e nacional por meio do maior pagamento de tributos.

Por tratar-se de uma entidade privada, internalizar os interesses de stakeholders somente causaria mais conflitos à condução dos negócios da companhia, resultando em ineficiências administrativas e consequente diminuição de lucro ${ }^{95}$.

A proteção de tais interesses externos seria mais bem atendida por meio de regulação apartada, i.e., legislações específicas de proteção aos stakeholders a serem observadas pela companhia ${ }^{96}$.

94 Vide Art. 189, LSA: "Do resultado do exercício serão deduzidos, antes de qualquer participação, os prejuízos acumulados e a provisão para o Imposto sobre a Renda." e Art. 191 da LSA: "Lucro líquido do exercício é o resultado do exercício que remanescer depois de deduzidas as participações de que trata o artigo $190 . "$

95“Por outro lado, quando o conflito se estabelece entre os interesses extra-societários e o interesse de longo prazo dos sócios na prosperidade e rentabilidade da empresa, parece mais adequado que este prevaleça sobre aqueles, sob pena de se conceber a sociedade como órgão público, voltado precipuamente ao interesse coletivo, o que desvirtuaria o preenchimento de sua função social e econômica específica." (MUNHOZ. Contribuições para revisão do modelo societário..., p. 48, apud, CUNHA, Rodrigo Ferraz Pimenta da. Estrutura de Interesses nas Sociedades Anônimas - Hierarquia e Conflitos. São Paulo: Quartier Latin, 2007, pp. 156-157). Neste sentido CUNHA afirma que: "O abuso de interferência no âmbito privado é comprovadamente prejudicial ao desenvolvimento econômico em diferentes níveis, sobretudo em longo prazo. (...) Não se nega aqui a existência de prementes necessidades públicas, mais ainda em um Estado caótico como o brasileiro, mas o nível de atuação para o seu enfrentamento deve observar a natureza jurídica de cada setor." (CUNHA, Rodrigo Ferraz Pimenta da. Estrutura de Interesses nas Sociedades Anônimas Hierarquia e Conflitos. São Paulo: Quartier Latin, 2007, pp. 153-154)

96 (i) HANSMANN e KRAAKMAN entendem que a maneira mais eficaz de proteger os interesses dos não acionistas reside fora da lei societária. A proteção para os trabalhadores, consumidores e para o público em geral decorreria de leis específicas neste sentido. Os autores admitem apenas que os credores merecem de fato alguma proteção direta na lei societária, tais como desconsideração da pessoa jurídica, limites à distribuição de dividendos quando o capital for inadequado. Porém, isso não significa agregar representantes de credores na administração das sociedades, apenas prever os meios os dispositivos legais capazes de coibir as práticas mencionadas acima. Os autores afirmam, ainda, por exemplo, que a visão prevalecente atualmente é a de que a participação de representantes de trabalhadores na administração da companhia tende a gerar decisões ineficientes e que tais custos são maiores do que eventuais benefícios auferidos com sua participação (HANSMANN, Henry e KRAAKMAN, Reinier. The End of History for Corporate Law. Georgetown Law Journal 89. 2001, pp. 439 e seguintes, p. 10). (ii) No trabalho de revisão que fizeram da obra acima, em 2011, os autores citam ainda a decadência dos modelos labor-oriented na Alemanha e managerial-oriented nos Estados Unidos nos últimos 15 anos (HANSMANN, Henry e KRAAKMAN, Reinier. Reflections on the end of history for corporate law. August 2011. Forthcoming in Abdul Rasheed 
Como comentário final, vale o destaque de que a primazia do interesse do acionista não deve (como a natureza concentracionista brasileira parece indicar) atender exclusivamente o acionista controlador. Na recente revisão do trabalho 'The End of History for Corporate Law', denominado 'Reflections on the end of history for corporate law', HANSMANN e KRAAKMAN adicionaram um quarto modelo de interesse social (em acréscimo aos modelos de prevalência do acionista, stakeholders - incluindo o Estado e trabalhadores - e administradores - managerial-oriented model), o da prevalência dos interesses do acionista controlador. Neste modelo, inexistiria a devida proteção dos acionistas minoritários, i.e., "unconstrained controlling shareholder empowered to manage corporations free of strong legal protections for minority shareholders ${ }^{97, ", ~ e, ~}$ consequentemente, não deveria ser visto como um modelo ideal a ser perseguido para um efetivo desenvolvimento do mercado de capitais.

\subsubsection{Crítica ao shareholder primacy}

Na opinião de CALIXTO SALOMÃO:

o efeito óbvio é o estímulo à busca desenfreada de aumento do valor de venda das ações por todos os agentes do mercado. Essa preocupação exclusiva, criadora de realidade unifocal de difícil controle por instrumentos jurídicos, é responsável, hoje, pela forte tendência à interpretação permissiva de regras contábeis, à mudança de regras contábeis ou até mesmo à maquiagem de balanços, fenômenos endêmicos e conhecidos na realidade societária americana, da qual o caso Enron e os escândalos com empresas de auditoria são apenas pequena parte, até agora visível. ${ }^{98}$

No mesmo sentido, VENTURA RIBEIRO:

Ao contratualismo juntou-se a tese do maior valor aos acionistas (shareholder value). Por tal teoria, o interesse social é identificado

and Toru Yoshikawa, Eds. Convergence Corporate Governance: Promise and Prospects. PalgraveMacMillan 2012. Disponível in < http://ssrn.com/abstract=2095419> Último acesso em 18.01.2014).

97 HANSMANN, Henry e KRAAKMAN, Reinier. HANSMANN, Henry e KRAAKMAN, Reinier. Reflections on the end of history for corporate law. August 2011. Forthcoming in Abdul Rasheed and Toru Yoshikawa, Eds. Convergence Corporate Governance: Promise and Prospects. Palgrave-MacMillan 2012, p. 15. Disponível in < http://ssrn.com/abstract=2095419> Último acesso em 18.01.2014).

${ }_{98}$ SALOMÃO FILHO, Calixto. O Novo Direito Societário. $4^{\mathrm{a}}$ ed. São Paulo: Malheiros, 2011, p. 32. 
apenas com a valorização das ações da companhia. (...). Porém, as premissas da tese shareholder value parecem ser equivocadas. (...) Primeiro, pelo fato das cotações de ações não dependerem apenas do desempenho da empresa, mas de outros fatores, como a economia nacional (...). Segundo, porque mesmo havendo valorização das ações, trata-se de satisfação virtual, pois o interesse só é realmente satisfeito no momento da venda das ações. Terceiro, porque a busca da maximização do valor das ações pode levar a operações arriscadas e até a fraudes, prejudicando os próprios acionistas. $^{99}$

\subsection{Teorias institucionalistas}

A escola institucionalista, por sua vez, teve origem da doutrina alemã ${ }^{100}$, segundo a qual "as sociedades existem e se desenvolvem não para atender aos interesses dos sócios (dos capitalistas), mas sim para servir ao interesse público representado pela empresa, como organização que transcende a sociedade comercial" ${ }^{101}$.

\subsubsection{Escolas clássicas}

$\mathrm{Na}$ Alemanha, no início do Século XX, ocorreram sérios conflitos entre empregador e empregado, sendo que para evitar uma crise dos setores de produção foi preciso internalizar ao menos parte dos interesses dos trabalhadores aos objetivos da sociedade anônima. Foi lá que teve início a eleição de representantes dos trabalhadores nos conselhos de administração ${ }^{102}$.

${ }^{99}$ RIBEIRO, Renato Ventura. Direito de Voto nas Sociedades Anônimas. São Paulo: Quartier Latin, 2009, pp. 119-120.

100 "Walter Rathenau, economista e homem de negócios alemão que, ao final da Primeira Guerra Mundial, em período de crise econômica, concebeu a grande sociedade como um instrumento para o renascimento econômico do país" (MUNHOZ, Eduardo Secchi. Empresa Contemporânea e Direito Societário - Poder de Controle e Grupos de Sociedades. Empresa contemporânea e direito societário - poder de controle e grupos de sociedades. São Paulo: Juarez de Oliveira, 2002, p. 38).

${ }^{101}$ MUNHOZ, Eduardo Secchi. Empresa Contemporânea e Direito Societário - Poder de Controle e Grupos de Sociedades. Empresa contemporânea e direito societário - poder de controle e grupos de sociedades. São Paulo: Juarez de Oliveira, 2002, p. 38.

${ }^{102}$ A lei societária alemã de 1937 adotou quase todos os princípios defendidos pela doutrina institucionalista. A esse respeito, cf. P. G. Jaeger, L'Interesse Sociale, Milano, Giuffré, 1972. Segundo CaliXTo Salomão: “(...) a escolha do grupo a participar depende do momento histórico da evolução do sistema econômico e social. Na Alemanha dos anos 60 a friç̧ão entre capital e trabalho havia tornado os 'custos de transação' enormes entre os dois fatores (...)" (SALOMÃO FILHO, Calixto. O Novo Direito Societário. $4^{a}$ ed. São Paulo: Malheiros, 2011, p. 61) 
Assim, foi num momento de crise social em que foi pensado um modelo capaz de internalizar interesses distintos daqueles dos sócios, como forma de amenizar o conflito e conceber o interesse social como vinculado ao interesse público.

RATHENAU, empresário, filósofo, sociólogo e homem de Estado, afirmava que "a grande empresa (...) não é mais uma organização de direito privado, mas um fator da economia nacional, a serviço de interesses públicos." ${ }^{103}$ A teoria entrou em crise a partir dos anos 1950 e como reação surgiu “(...) a lei (alemã) acionária de 1965, que reforçou o papel da assembleia dos acionistas e os direitos dos acionistas minoritários." 104

Partindo dessa concepção inicial de prevalência de um interesse público sobre o privado, outras escolas clássicas surgiram para explicar a presença de outros interesses além daqueles dos sócios ${ }^{105}$.

${ }^{103}$ FRANÇA, Erasmo Valladão Azevedo e Novaes. Conflito de Interesses nas assembleias de S.A. São Paulo: Malheiros, p. 22. CALIXTO SALOMÃo ensina ainda que: "toda construção da teoria de Rathenau é dirigida a traduzir em termos jurídicos a função econômica, de interesse público e não meramente privado, da macroempresa. Isso se fez através da valorização do papel do órgão de administração da sociedade por ações, visto como órgão neutro, apto à defesa do Unternehmensinteresse (interesse empresarial). Procede-se a uma degradação relativa da importância da assembleia, o que influenciará sobretudo os direitos dos sócios minoritários (...). Os críticos dessa teoria argumentam ser ilógico considerar a administração (Verwaltung) um órgão neutro de defesa do interesse social. Dada a sua estreita ligação aos interesses dos sócios majoritários, a autonomia e tendencial irresponsabilidade decorrente do recurso constante ao interesse social acaba funcionando frequentemente contra os interesses do sócio minoritário e no interesse do sócio controlador - cf. P. G. Jaeger, L'interesse sociale, cit., p. 29." (SALOMÃO FILHO, Calixto. O Novo Direito Societário. $4^{a}$ ed. São Paulo: Malheiros, 2011, p. 33)

${ }^{104}$ SALOMÃO FILHO, Calixto. O Novo Direito Societário. $4^{\mathrm{a}}$ ed. São Paulo: Malheiros, 2011, p. 34.

${ }^{105}$ (i) Sobre a escola institucionalista no direito norte-americano, (i) COMPARATO informa que "Henry Ford não hesitou em sustentar claramente que a finalidade precípua de sua companhia não era produzir lucros para distribuí-los aos acionistas, mas reinvestir o máximo possível de modo a criar novos empregos e aumentar o padrão de vida da comunidade inteira" (Aspectos Jurídicos...cit., pp. 53/54 e 56, apud, (FRANÇA, Erasmo Valladão Azevedo e Novaes. Conflito de Interesses nas assembleias de S.A. Malheiros, São Paulo: 1993), e (ii) “(...) o movimento institucionalista também se consolidou, porém com fundamentos políticos diversos do proposto por Rathenau, já que num contexto de liberdade política e de liberalismo acentuado. Naquele país, as empresas têm fundamental importância, a ponto de transcenderem uma visão meramente privatista em seu papel socioeconômico. Por conseguinte, devem elas ser submetidas ao interesse público. Dessa ideologia decorre a grande liberdade dos órgãos de administração das companhias, quanto ao problema da sua autocapitalização, cabendo-lhes determinar os dividendos que devem ser distribuídos." CARVALHOSA, Modesto. Comentários à lei das sociedades anônimas. $5^{\mathrm{a}}$ ed. São Paulo: Saraiva, 2011. vol. 2, p. 557). (ii) Também neste sentido a célebre frase de RATHENAU "atribuída a um administrador da Norddeutscher Lloyd, e que, segundo Mengoni (e outros 'contratualistas'), [que] retrata de maneira insuperável o contraste entre a concepção institucionalista e a contratualista (...). A um acionista que teria vindo reclamar a distribuição de dividendos, o mencionado administrador teria respondido: a administração não está aqui para distribuir dividendos, mas para fazer navegar os navios sobre o Reno (...). Tal frase, objeto de viva polêmica na doutrina italiana dos anos cinquenta, correu mundo (...)" (FRANÇA, Erasmo Valladão Azevedo e Novaes. Conflito de Interesses nas assembleias de S.A. São Paulo: Malheiros: 1993, pp. 35-36). (iii) CARVALHOSA nos conta também do caso Fruehauf: "em que a Corte de Apelação de Paris entendeu válida a decisão do Tribunal de Comércio de Corbeil-Essones de nomear um administrador judicial para gerir provisioriamente aquela companhia subsidiária americana, visando ao interessa da empresa, cujo equilíbrio financeiro e econômico, bem como o interesse de centenas de operários, estava ameaçado pela decisão da matriz 
A primeira delas foi a teoria institucionalista da empresa em si (Unternehmen na sich). Foi concebida sob uma visão publicística da sociedade anônima em que deveriam ser atendidos os interesses de sócios, trabalhadores e demais stakeholders. Para tal fim, preconizava a existência de uma administração forte e independente capaz de atuar como árbitro do interesse público da companhia ${ }^{106}$.

A segunda teoria institucionalista é da pessoa em si (Person an sich). Segundo VALLADÃO, essa teoria foi baseada na concepção organicista de GIERKE da 'realidade' da pessoa jurídica ${ }^{107}$, de forma que "o interesse social não seria, como na da Unternehmen an sich, o interesse da empresa, mas sim o interesse da própria sociedade, enquanto pessoa jurídica distinta da pessoa de seus membros" ${ }^{108}$.

americana de embargar as vendas feitas por ela à República da China." (Faculdade Internacional da Universidade da Pensilvânia. Cases. Seminário Francês. Material n. 8. Houen - Paris, 1977; Dominique Schimidt, Les droits de la minorité, cit., p. 146; G. Ragusa Maggione, Rivista delle Societá, 1969, n. 2, apud CARVAlHOSA, Modesto. Comentários à lei das sociedades anônimas. 5a ed. São Paulo: Saraiva, 2011. vol. 2, p. 557)

106 Segudo VALLADÃO, JAEGER assim a resume: “a) (...) visão publicística dos problemas da sociedade anônima (...), na qual sobrelevam interesses os mais diversos, não apenas os dos acionistas, mas também os dos trabalhadores e seus dependentes, os dos consumidores e, bem assim o interesse coletivo ao desenvolvimento da economia nacional, (...); b) (...) reconhecimento à empresa de um interesse próprio, dirigido não à produção de lucros (...), mas à melhor eficiência produtiva (...); c) tendência de subtrair dos acionistas (...) o controle da empresa, para confiá-lo a uma administração estável e coesa, o quanto possível independente de uma mutável maioria de acionistas (...); e d) redução e todos os direitos dos acionistas (...), condicionados ao superior interesse da empresa (...)" (FRANÇA, Erasmo Valladão Azevedo e Novaes. Conflito de Interesses nas assembleias de S.A. São Paulo: Malheiros: 1993, p. 23)

107 “(...) Foi Gierke o autor da doutrina segundo a qual a pessoa jurídica seria uma entidade real, caso em que a sociedade teria um interesse próprio não coincidente com os interesses particulares dos sócios, em relação aos quais teria primazia. Neste sentido, ao exercer os poderes sociais, os sócios estariam proibidos de fazer com que seu interesse pessoal viesse a prevalecer sobre o interesse social, o qual seria autônomo." (VERÇOSA, Haroldo Malheiros Duclerc. Curso de direito comercial. v. 2. $2^{\mathrm{a}}$ ed. São Paulo: Malheiros, 2010, p. 60)

${ }^{108}$ FRANÇA, Erasmo Valladão Azevedo e Novaes. Conflito de Interesses nas assembleias de S.A. São Paulo: Malheiros: 1993, p. 27. (i) VALLADÃo ensina que "É evidente, porém, a diferença entre as duas doutrinas. $\mathrm{Na}$ da pessoa em si, o interesse, reduzido ao da pessoa jurídica, não é externo à sociedade. Dessa forma, um dos pilares fundamentais da doutrina da empresa em si, ou seja, o reconhecimento de interesses públicos na disciplina da sociedade anônima e a outorga de sua tutela aos administradores, cai por terra. Ademais, na concepção organicista de Gierke sobre a pessoa jurídica, os direitos da minoria são protegidos, ao contrário do que ocorre na doutrina da empresa em si, que concede à maioria ampla discricionariedade na condução dos negócios sociais." (FRANÇA, Erasmo Valladão Azevedo e Novaes. Conflito de Interesses nas assembleias de S.A. São Paulo: Malheiros: 1993, p. 27). (ii) Nas palavras de VENTURA RIBEIRO: "Para suprir a lacuna da defesa de interesse de entidade despersonalizada, foi proposta a teoria da pessoa em si (Person an sich), lastreada na personalidade jurídica da sociedade como fundamento. (...) No entanto, a partir do reconhecimento de um interesse próprio da sociedade e de sua personalidade jurídica como fundamento, não se pode falar em interesse externo e, por consequência, em interesse público e de sociedade pertencente a grupo. Colide, portanto, com a base inicial do institucionalismo, fundada no interesse público. (...) Tendo em vista o [não] reconhecimento de outros interesses na empresa, a teoria não está em consonância com o atual estágio de desenvolvimento do direito societário." (RIBEIRO, Renato Ventura. Direito de Voto nas Sociedades Anônimas. São Paulo: Quartier Latin, 2009, pp. 109-110) 
VERÇOSA é um dos defensores desta teoria no Brasil:

quando o legislador se refere ao interesse da sociedade, ele não quer significar que se trate de interesse interno ou externo, mas o do próprio ente societário; e este somente pode ser identificado à luz da cláusula do objeto social, caso a caso. Desta forma, o interesse da companhia não pode ser confundido com os interesses dos acionistas em geral, do acionista controlador, dos administradores, dos trabalhadores, dos fornecedores, da comunidade em que ela atua, do Poder Público e de tantos outros àquela relacionados. $\mathrm{Na}$ verdade, é muito frequente que o interesse da sociedade esteja em aberto conflito com outros de natureza interna e externa. Trata-se, podemos dizer, quase, mesmo, de uma regra, e não de uma exceção. ${ }^{109}$

Outra teoria é a do direito da empresa acionária (Recht der

Aktienunternehmung), que nas palavras de VALLADÃO:

(...) negava que a empresa fosse titular de interesses, mas via confluir na empresa sujeitos diversos, titulares de um interesse comum, ou seja, além dos acionistas, os membros da administração, os credores e os trabalhadores e seus dependentes. Tal interesse comum era por ele concebido como a soma ou unidade dos interesses individuais daqueles sujeitos que, coligados

${ }^{109}$ VERÇOSA, Haroldo Malheiros Duclerc. Curso de direito comercial. v. 2. $2^{\mathrm{a}}$ ed. São Paulo: Malheiros, 2010, p. 265. VERÇOSA cita, ainda, alguns exemplos acerca da perrmanência da tese de GIERKE: “(i) a companhia quer pagar a menor importância possível a título de dividendos, enquanto os acionistas desejam receber o máximo que seja possível; (ii) a companhia quer pagar os menores salários e obter o máximo proveito, em contraposição ao desejo dos seus empregados; (iii) a sociedade, no limite, almeja crescer de forma desmesurada e sem qualquer restrição, enquanto o Poder Público deseja limitar seu tamanho e poder econômico; (iv) a companhia gostaria de não pagar qualquer tributo, enquanto o Estado procura cobrar o máximo que seja possível, deixando-se simplesmente vegetar; (v) os administradores almejam a melhor remuneração e a mínima responsabilidade, enquanto a companhia espera que eles se contentem com uma remuneração tão somente justa e que respondam ilimitadamente pelos atos e omissões danosos ao patrimônio daquela (vi) os consumidores gostariam de pagar o preço de um "Lada" e receber uma "Ferrari". E assim, por diante, numa longa relação." (VERÇOSA, Haroldo Malheiros Duclerc. Curso de direito comercial. v. 2. $2^{\mathrm{a}}$ ed. São Paulo: Malheiros, 2010, pp. 265-266). Também neste sentido WARDE JR. que manifesta sua opinião em favor da teoria da pessoa em si (e, inclusive, criticando a teoria da empresa em si): “(...) apenas falar-se em interesse da companhia como interesse da atividade empresarial (...) é - em vista da carência de um sujeito interessado - de todo ilógico." (WARDE Jr., Walfrido Jorge. Qual o Modelo de governança corporativa que exsurge da disciplina das reorganizações, in Fusão, Cisão, Incorporação e Temas Correlatos. São Paulo: Quartier Latin, 2009, p. 157). WARDE JR. complementa (citando o jurista português CORDEIRO): “A empresa (...) não tem hoje, uma dogmática minimamente capaz de lhe conferir um papel nuclear ou sequer, substancial, no Direito do comércio. Designadamente, não é configurável atribuir-lhe 'interesses' próprios, capazes de ditar, inflectir ou esclarecer regimes. Fica-nos, pois, apenas a sociedade." (CORDEIRO, A. Menezes. Da responsabilidade civil dos administradores das sociedades comerciais. Lisboa: Lex, 1997, p. 521, apud, WARDE Jr., Walfrido Jorge. Qual o Modelo de governança corporativa que exsurge da disciplina das reorganizações, in Fusão, Cisão, Incorporação e Temas Correlatos. São Paulo: Quartier Latin, 2009, p. 157. 
na empresa, nela coordenam seus respectivos escopos. ${ }^{110}$

Esta teoria ganhou importância e influenciou diversas legislações no mundo, especialmente a atual lei alemã e nossa LSA. Sua popularidade se justifica, especiamente, (i) na mitigação dos ideais iniciais de Rathenau que ao dar prevalência ao interesse público sobre o privado tenderiam a não estimular a atividade empresarial, e (ii) no reconhecimento de diversos outros interesses em conjunto com os dos sócios. ${ }^{111}$

\subsubsection{Escola moderna e doutrina brasileira}

Modernamente, o institucionalismo foi assumindo novas facetas, especialmente em virtude do surgimento de discussões sobre função e responsabilidade social da empresa. Nesse sentido, surgiu o institucionalismo organizativo que, nas palavras de CALIXTO SALOMÃO:

sendo mais organizativo que institucional, não se preocupa, como o anterior, em preservar o conceito de personalidade jurídica (...) fixa os parâmetros para a discussão sobre o tipo de organização mais apta a garantital interesse [i.e., a manutenção da empresa]. ${ }^{112}$

\footnotetext{
${ }^{110}$ FRANÇA, Erasmo Valladão Azevedo e Novaes. Conflito de Interesses nas assembleias de S.A. São Paulo: Malheiros: 1993, p. 28-29. Para LEÃES: “a lei adota, portanto, a orientação do chamado 'direito de empresa acionária' (Recht der Aktienunternehmung), consagrada na Alemanha, que encara a lei do anonimato como instrumento de tutela da empresa, na medida em que a sociedade anônima é uma técnica de organização empresarial, não lhe atribuindo propriamente um interesse isolado, como na teoria da 'empresa em si' (Unternehmen an sich), mas reconhecendo, na própria empresa, uma 'composição dos interesses das várias pessoas que dela participam' (Schutz dês Unernehmens in Sinne eines Ausgleichs alle beteiligten Interessen)" (LEÃES, Luiz Gastão Paes de Barros. Conflito de Interesse. In Estudos e pareceres sobre sociedades anônimas. São Paulo: Revista dos Tribunais, 1989, p. 21)

111 Sobre a teoria institucionalista do direito da empresa acionária (Recht der Aktienunternehmung), VENTURA RIBEIRO ensina que “(...) deve-se entender por interesse social o interesse coletivo dos sócios. Não se tutela um interesse isolado, como na empresa em si, mas reconhece a composição de diversos interesses. (...) A atuação da administração deve ocorrer no interesse dos acionistas, credores, trabalhadores e konzern. A teoria influenciou as atuais leis alemã e brasileira do anonimato. Como exemplos de sua aplicação, a cogestão (...) e o reconhecimento da função social da empresa. (...) Ao contrário da Person an Sich, reconhece a existência de interesses externos, como os de trabalhadores e credores. Mas difere da teoria da empresa em si por conceber o interesse da empresa como interesse comum dos sócios e não o público, além de não admitir a intevenção estatal." (RIBEIRO, Renato Ventura. Direito de Voto nas Sociedades Anônimas. São Paulo: Quartier Latin, 2009, p. 110)

${ }^{112}$ SALOMÃO FILHO, Calixto. O Novo Direito Societário. $4^{\mathrm{a}}$ ed. São Paulo: Malheiros, 2011, pp. 36 e 37. Também sobre o institucionalismo moderno comenta VENTURA RIBEIRO: “Ao institucionalismo, como reconhecimento dos diversos interesses sociais presentes na empresa, somou-se a ideia de responsabilidade social. (...) enquanto a busca do interesse e da função social da empresa constitui deveres legais (Lei 6.404/76, arts. 115, 116, parágrafo único, 154 e 165), a responsabilidade social é mera faculdade (Lei 6.404/76, art. 154, $4^{\circ}$ ).” (RIBEIRO, Renato Ventura. Direito de Voto nas Sociedades Anônimas. São Paulo: Quartier Latin, 2009, pp. 119-120)
} 
Além das posições de VERÇOSA (defensor da teoria institucionalista da pessoa em si) e LEÃES (partidário da teoria institucionalista da empresa acionária), destacamos a seguir outros autores de renome que se posicionaram, ainda que de forma genérica, em favor do institucionalismo.

Embora tido por contratualista por alguns doutrinadores, CARVALHOSA afirma que:

(...) Ao tomar a lei explicitamente o partido institucionalista, no tocante à finalidade das atribuições dos administradores (arts. $154 \mathrm{e}$ s.), mais uma vez declara que existe um interesse social independente ou, pelo menos, não totalmente identificado com os interesses dos acionistas. Assim, do claro texto do art. 154 e da interpretação da lei societária vigente, nitidamente institucionalista, conclui-se que o interesse social transcende ao do acionista, por isso que de ordem superior e de natureza autônoma. ${ }^{113}$

Também nesse sentido opinam TEIXEIRA e GUERREIRO:

A sociedade [anônima], segundo as concepções mais modernas, não organiza apenas os interesses comuns dos sócios. Em virtude do complexo de relações derivadas de sua atividade que projetam relevantes e irrecusáveis efeitos sobre o meio social, a conjuntura econômica e a própria ambiência política, a companhia mais e mais se reveste de interesse publicístico a justificar, aliás, crescente intervenção do Estado em sua vida e em seu desenvolvimento. Não é apenas sob o aspecto da captação de poupanças junto ao público investidor que se revela a função social da companhia. Como unidade de produção, a empresa se insere no quadro econômico de uma nação como um veículo de riquezas, mobilizando matériasprimas e produtos intermediários, comprando e vendendo, prestando serviços, recolhendo tributos, assalariando empregados, enfim, contribuindo para o desenvolvimento da comunidade em

${ }^{113}$ CARVALHOSA, Modesto. Comentários à lei das sociedades anônimas. 5a ed. São Paulo: Saraiva, 2011. vol. 3, p. 27. A confusão acerca da posição assumida por CARVALHOSA, a nosso ver, se dá pelo fato de o autor entender que, como a LSA determina (nos artigos 115 e 116) que o acionista deve respeitar o interesse social, haveria uma presunção de que toda manifestação dos acionistas (instruções da assembleia geral ou reunião prévia no contexto de acordos de acionistas) estaria de acordo com tal interesse. Caso não esteja, o acionista estaria incorrendo em abuso e a LSA confere os meios apropriados de responsabilização. Em outras palavras, ao dizer que a administração deve obedecer às instruções dos acionistas pelo fato de o interesse destes representar o interesse social, o autor está assumindo a premissa de que o acionista observou o interesse da companhia, mas não significa dizer que tal interesse não possa (e deva) considerar outros além daqueles dos sócios. Vide o seguinte trecho extraído de uma de suas obras: "Por outro lado, no caso de abuso, não se pode falar em interesse dos acionistas, mas, sim em desvio desses interesses, que se refletem prejudicialmente no interesse social. Nesse caso, haverá quebra do dever fiduciário instituído no parágrafo único do art. 116 da lei societária. Assim, quando o interesse do controle é legitimamente exercido, por si só estará atendido o interesse social. Este não transcende aquele." (CARVALHOSA, Modesto. Acordo de Acionistas. São Paulo: Saraiva, 2011, p. 239) 
geral. $^{114}$

Por fim, destacamos as posições de COMPARATO e MunHOZ, respectivamente:

$\mathrm{E}$

O reconhecimento de interesses externos a serem protegidos não significa transformar a sociedade em órgão público, tendo por objetivo primordial o interesse coletivo. O escopo lucrativo está expressamente estabelecido no art. $2^{\circ}$ da lei acionária brasileira, e não pode ser descurado. Fica subordinado, porém, aos interesses comunitários e nacionais, que prevalecem em caso de conflito, pois a liberdade de iniciativa não torna absoluto o direito ao lucro, nem o põe acima dos valores da ordem econômica e social, expressos na Constituição. ${ }^{115}$

Com essas considerações, parece possível sugerir à reflexão a definição do interesse social na prosperidade, rentabilidade e distribuição equitativa de resultados entre os diversos participantes da atividade empresarial, a longo prazo. Esse pode ser o critério a ser observado na definição dos interesses externos a serem interiorizados e na solução dos conflitos entre os diversos interesses a serem protegidos. ${ }^{116}$

114 TEIXEIRA, Egberto Lacerda; GUERREIRO, José Alexandre Tavares. Das sociedades anônimas no direito brasileiro, v. 1. São Paulo: Buchatsky, 1979, p. 297. Também nesse sentido: (i) FrANCO e SzTAJN: "Se há quem afirme dever a sociedade visar ao lucro sem levar em conta outros interesses, pode-se dizer que essa é visão incorreta ou até tacanha. Não se trata de pensar a sociedade anônima sob perspectiva publicista ou institucionalista, mesmo a mitigada. Trata-se, ao revés, de pensar a companhia como um dos agentes sociais que criam riqueza, utilidades, bem-estar e, por isso, o respeito da comunidade em que atua pode determinar o sucesso ou fracasso do empreendimento. É o que alguns denominam 'empresa cidadã'. (FRANCO, Vera Helena de Melo; SZTAJN, Rachel. Direito Empresarial II: sociedade anônima, mercado de valores mobiliários. $2^{a}$ ed. ver. atual. e ampl. São Paulo: Revista dos Tribunais, 2009, p. 192); e (ii) WARDE JR.: "A lei brasileira de sociedades anônimas deixa transparecer a influência recebida da doutrina alemã, ao referir-se ao interesse da companhia como expressão sobreposta ao interesse da empresa em sua forma subjetivada. (...) apenas falar-se em interesse da companhia como interesse da atividade empresarial (...) é - em vista da carência de um sujeito interessado - de todo ilógico. (...) Os precedentes jurisprudenciais produzidos por nossos tribunais levam a concluir que os interesses da companhia não se resumem aos interesses dos controladores [Recurso de Apelação no 126.712.4/3, j. em 10 de dezembro de 2002)] (...). A análise dos julgados, em suma, torna claro que, em vista dos interesses das companhias, não é lícito ao controlador e aos administradores, em detrimento dos demais acionistas e detentores-fornecedores de recursos não-acionistas, apropriarem-se de elementos de produção da companhia. (...) O conceito legal indeterminado de interesse da companhia é, em vista do conteúdo das referidas decisões, precisado para sobrepor-se aos interesses dos sócios no cumprimento de seus direitos comuns, porque será justamente a eles que o impedimento à apropriação indevida de ativos sociais aproveitará." (WARDE Jr., Walfrido Jorge. Qual o Modelo de governança corporativa que exsurge da disciplina das reorganizações, in Fusão, Cisão, Incorporação e Temas Correlatos. São Paulo: Quartier Latin, 2009, p. 159)

${ }^{115}$ COMPARATO, Fábio Konder; SALOMÃO FILHO, Calixto. O poder de controle na sociedade anônima. $5^{\mathrm{a}}$ ed. Rio de Janeiro: Forense, 2008, p. 301, apud, MUNHOZ, Eduardo Secchi. Empresa contemporânea e direito societário - poder de controle e grupos de sociedades. São Paulo: Juarez de Oliveira, 2002, p. 42.

${ }^{116}$ MUNHOZ, Eduardo Secchi. Empresa contemporânea e direito societário - poder de controle e grupos de sociedades. São Paulo: Juarez de Oliveira, 2002, p. 48. MUNHOZ reafirmou seu entendimento dez anos depois, conforme segue: "Superadas as visões contratualistas e institucionalistas mais extremadas, não remanesce dúvida de que o interesse social esta longe de restringir-se à maximização dos lucros, havendo de ser considerados os demais titulares de interesses afetados pela atividade empresarial. A sociedade (e a empresa) exerce sua função social quando organiza e estrutura esses diversos interesses, contribuindo para o 


\subsection{Análise econômica do direito e a teoria do contrato-}

organização

Outras escolas além das clássicas estudadas acima contribuíram com elementos para o entendimento do complexo e controverso conceito de interesse social ${ }^{117}$.

Segundo a teoria econômica, a norma deve ser analisada a partir de sua eficiência econômica ${ }^{118}$, i.e., dos custos oriundos de sua aplicação. Um determinado comportamento ou agente, por exemplo, pode deixar de ser objeto de regulação se os custos a serem incorridos em tal exercício forem maiores que os benefícios verificados. Da mesma forma, uma norma jurídica deve ser interpretada e aplicada da maneira menos custosa e que trouxer mais benefícios aos envolvidos ${ }^{119}$.

Sob essa perspectiva e a partir dos trabalhos de COASE e CALABRESI:

aumento do bem-estar social. No direito brasileiro, essa é a conclusão que necessariamente decorre do art. 170 da Constituição Federal e do art. 116 da Lei das Sociedades Anônimas (...)" (MUNHOZ, Eduardo Secchi. Quem deve comandar a companhia? Alocação do poder empresarial: sistema de freios $e$ contrapesos. In Estudos em Homenagem a Modesto Carvalhosa. São Paulo: Saraiva, 2012, pp. 505-506).

117 Interessante notar que, com o tempo, a divisão inicial estanque entre as escolas contratualista e institucionalista foi bastante mitigada e os conceitos bastante aproximados, fato este que (em conjunto com a complexidade e subjetividade do tema), pode ter contribuído para o surgimento de novas escolas. Sobre tal aproximação das escolas contratualista e institucionalista: "Uma vertente da teoria contratualista inclui na categoria de sócios não apenas os atuais, mas também os futuros, em enfoque de longo prazo que realça a importância da preservação da empresa, como elemento do interesse social. Por outro lado, a teoria institucionalista tem uma vertente 'integracionista', que se afasta do tom publicístico exagerado de Rathenau, para conceber o interesse social como o interesse harmônico e comum dos vários tipos de sócios e trabalhadores, que se traduz no interesse pela preservação da empresa."(MUNHOZ, Eduardo Secchi. Empresa contemporânea e direito societário - poder de controle e grupos de sociedades. São Paulo: Juarez de Oliveira, 2002, p. 43)

118 "A teoria econômica sugere que a melhor interpretação das normas jurídicas é oferecida pelo princípio econômico. Segundo esse princípio, as normas jurídicas são eficientes quando permitem a maximização da riqueza global, mesmo que isso seja feito à custa de prejuízo a um agente econômico específico. Trata-se da aplicação do teorema de Kaldor Hicks, segundo o qual uma solução é eficiente se as vantagens obtidas pelos vencedores forem superiores aos prejuízos sofridos pelos perdedores." (MUNHOZ, Eduardo Secchi. Empresa contemporânea e direito societário - poder de controle e grupos de sociedades. São Paulo: Juarez de Oliveira, 2002, p. 17)

119 “(...) De acordo com Coase, se os custos de transação fossem nulos, isto é, se não custasse nada às partes a negociação de um acordo privado, a riqueza da comunidade seria necessariamente aumentada, independentemente da regra estabelecida na lei. (...) Logo, a norma jurídica e a decisão judicial deveriam avaliar qual teria sido a solução encontrada pelas partes se os custos da negociação fossem nulos, pois, dessa forma, seria observado o princípio da maximização da riqueza." (MUNHOZ, Eduardo Secchi. Empresa contemporânea e direito societário - poder de controle e grupos de sociedades. São Paulo: Juarez de Oliveira, 2002, p. 19) 
a sociedade é vista como um feixe de contratos, ou seja, a sociedade seria um ente subscritor de um grupo de contratos, ou seja, que começa pelos contratos com os sócios e vai desde contratos com fornecedores e clientes até contratos com trabalhadores e contratos de empréstimo necessários para suprir as necessidades de fundos de empresa. (...) Cria-se (...) a ideia de que o interesse social deve estar relacionado à criação de uma organização capaz de estruturar de forma mais eficiente as relações jurídicas que envolvem a sociedade. ${ }^{120}$

Baseando-se nos princípios trazidos pela análise econômica do direito ${ }^{121}$, CALIXTO SALOMÃo desenvolveu a teoria do contrato-organização:

\begin{abstract}
organização na acepção jurídica significa a coordenação da influência recíproca entre atos. (...). Note-se, no entanto, que essa teoria, apesar de dar guarida a uma crítica de ordem econômica como a exposta retro, não é uma teoria econômica, mas sim jurídica. Não há a redução do interesse social a uma organização direcionada simplesmente a obter a eficiência econômica. O objetivo da compreensão da sociedade como organização é exatamente o melhor ordenamento dos interesses nela envolvidos e a solução dos conflitos entre eles existentes. O interesse social passa, então, a ser identificado com a estruturação e organização mais apta a solucionar os conflitos entre esse feixe de contratos e relações jurídicas. $^{122}$
\end{abstract}

A adoção dessa teoria passaria por repensar modelos jurídicos de organização e administração de determinada atividade empresarial a fim de conciliar todos os interesses envolvidos $^{123}$. A empresa (sob o perfil funcional) estaria destacada de todos os interesses

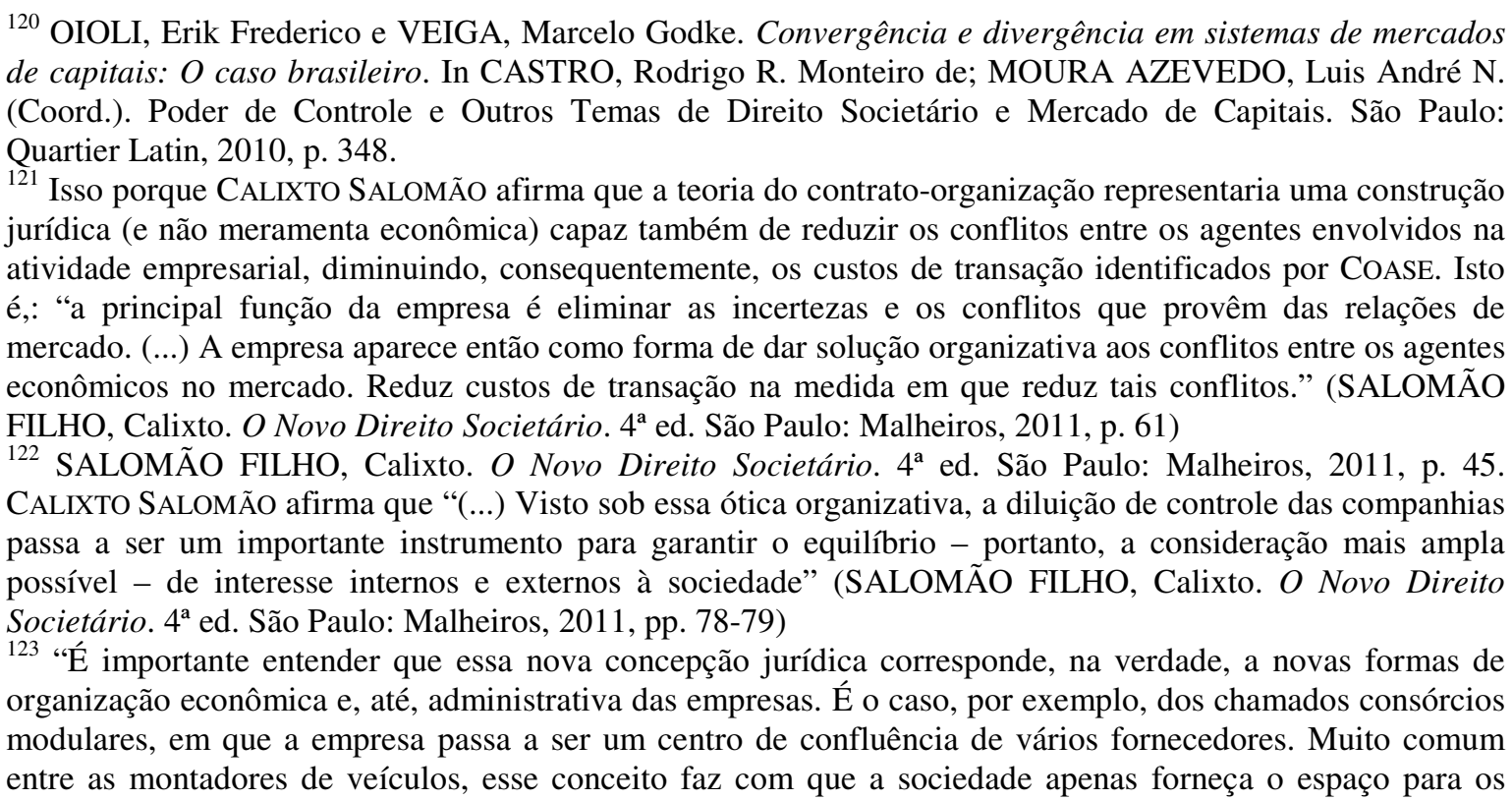


nela envolvidos (inclusive dos sócios) e a norma forneceria a instrumentalização jurídica mais eficiente a abarcar e conciliar tais interesses ${ }^{124}$.

\subsubsection{Crítica à análise econômica e ao contrato-organização}

VERÇOSA tece interessantes críticas sobre a utilização da análise econômica ao conceito de interesse social, bem como à teoria do contrato-organização, respectivamente:

Para efeito da busca do conceito de interesse da companhia não nos serve o conceito de Ronald Coase, no sentido de que ela é um feixe de contratos. Os contratos inerentes à companhia são aqueles que dão nascimento (plurilateral, associativo ou aberto), bem como os contratos externos, ou seja, com empregados, fornecedores e clientes ou consumidores. Não existem contratos internos na sociedade. Ela não contrata com seus administradores, ao menos no nosso Direito, pois estes são órgãos da sociedade. Ela não contrata individual ou coletivamente com seus acionistas o pagamento dos dividendos: isto faz parte dos direitos essenciais de quem arrisca seus recursos em uma atividade de risco. Os contratos com os empregados e prestadores de sérvios não são de natureza interna, mas externa. Então o feixe de contratos de que fala Coase explica a

fornecedores que montam diretamente as peças no veículo. A empresa montadora passa a então a ser simples e puro feixe de organização de contratos. Isso permite a redução de custos e - espera-se - a melhoria da qualidade. Interessante é notar que essa nova estrutura administrativa e - espera-se - jurídica em consequências práticas diretas sobre a própria personalidade jurídica da empresa/organização. Problema interessante surgido nas empresas que empregam o conceito de consórcio modular é o das autorizações administrativas. $\mathrm{Na}$ verdade as empresas de autopeças que instalam filiais dentro da empresa montadora deixam de precisar de muitas autorizações administrativas. É como se suas personalidades jurídicas fossem interpenetradas pela personalidade jurídica da montadora, pessoa jurídica cujo único e exclusivo fim passa a ser o de organizar o seu trabalho. (...)" (SALOMÃO FILHO, Calixto. O Novo Direito Societário. 4a ed. São Paulo: Malheiros, 2011, pp. 45-46)

124 (i) OIOLI e VEIGA sobre a teoria do contrato-organização: "A partir da concepção da teoria organizativa, percebe-se uma clara alteração na função da sociedade, que passa a ser a organização racional dos diversos interesses que a envolvem. Diante disso, a estrutura organizacional na companhia adquire grande importância, pois os órgãos societários passam a ter papel fundamental na mediação dos interesses conflitantes, seja através da incorporação no órgão de todos os agentes que têm interesse, ou através da criação de órgãos independentes, não passíveis de serem influenciados pelos interesses conflitantes." (OIOLI, Erik Frederico e VEIGA, Marcelo Godke. Convergência e divergência em sistemas de mercados de capitais: O caso brasileiro. In CASTRO, Rodrigo R. Monteiro de; MOURA AZEVEDO, Luis André N. (Coord.). Poder de Controle e Outros Temas de Direito Societário e Mercado de Capitais. São Paulo: Quartier Latin, 2010, p. 348). (ii) VENTURA RIBEIRO sobre a teoria do contrato-organização: "Da última [tese do contratoorganização] tem-se a ideia do contrato não como pluralidade de direitos subjetivos, mas de organização para exercício da atividade. E o interesse social é o da organização e poder ser definido em lei ou pela vontade das partes. Em suma, é uma forma de conciliação entre as concepções contratualistas e institucionalistas, reconhecendo o interesse dos sócios pelo lucro como também o interesse público, além do interesse da organização em sua preservação. (...)" (RIBEIRO, Renato Ventura. Direito de Voto nas Sociedades Anônimas. São Paulo: Quartier Latin, 2009, p. 121) 
empresa, não a sociedade que a exerce. ${ }^{125} 126$

Inaplicável para o fim em vista é também a Teoria do ContratoOrganização, que, segundo Fábio Konder Comparato e Calixto Salomão Filho, "visa não a dar guarida a diferentes interesses ordenados a um fim, mas organizar tais relações em prol de um interesse societário destacável do individual". Mas pergunta-se, com toda propriedade, este 'interesse societário destacável do individual' não nos leva de volta a Gierke? A companhia não é titular de um interesse diverso de qualquer outro interesse interno ou externo, que lhe dá vida e identidade própria? Mais uma vez repita-se: o interesse da companhia, tal como posto pelo legislador brasileiro nas normas societárias correspondentes, é único para cada uma delas e deve ser identificado pelo exame do caso concreto toda vez que surgir um litígio a seu respeito. ${ }^{127}$

\footnotetext{
${ }^{125}$ VERÇOSA, Haroldo Malheiros Duclerc. Curso de direito comercial. v. 2. $2^{\mathrm{a}}$ ed. São Paulo: Malheiros, 2010, p. 266. Destaque também para as críticas de CALIXTO SALOMÃo e MuNHOZ à análise econômica do direito, respectivamente: (i) "[o] cenário impressiona pela falta de uma preocupação precipuamente jurídica em relação às organizações societárias. Entender o direito societário como algo capaz de influenciar a realidade e não como uma organização que reproduz padrões econômicos de eficiência ou tecnologia, implica direcionar a pesquisa para caminhos completamente diversos. (...) Implica para tanto fazer estudos verdadeiramente interdisciplinares que não tenham em conta exclusivamente variáveis exógenas e determinantes do ponto de vista econômico (como o lucro ou a produção tecnológica), mas também estudos sociológicos e antropológicos sobre o comportamento de aglomerados humanos. (...) $\mathrm{Na}$ verdade, o comportamento cooperativo e o cumprimento de regras éticas entre acionistas é algo absolutamente ínsito ao conceito de sociedade. Seu cumprimento não é, no entanto, espontâneo" (SALOMÃO FILHO, Calixto. $O$ Novo Direito Societário. $4^{\mathrm{a}}$ ed. São Paulo: Malheiros, 2011, p. 55); (ii) "A crítica fundamental que pode ser dirigida a essa teoria, porém é a de que pretender eleger um único objetivo - o econômico - ao sistema jurídico. (...) a análise econômica pretende transplantar para o Direito, com exatidão matemática, os modelos causais de análise utilizados pela Economia, descurando do momento valorativo da produção de toda e qualquer norma jurídica. (...) além da eficiência econômica, é preciso que as normas jurídicas possam ser justificadas segundo um padrão ético, moral, aceito pela comunidade." (MUNHOZ, Eduardo Secchi. Empresa contemporânea e direito societário - poder de controle e grupos de sociedades. São Paulo: Juarez de Oliveira, 2002, p. 22)

${ }^{126}$ Embora a crítica (sobre a impossibilidade de se considerar isoladamente a análise econômica do direito) tecida seja bastante procedente, a importância da utilização da análise econômica do direito como um dos mecanismos de aplicação, interpretação e elaboração de normas é reconhecida pela maioria da doutrina, conforme bem resumido por MUNHOZ a seguir: "o estudo do direito societário não pode prescindir da análise do efeito econômico de seus institutos e regras. A compreensão econômica oferece o instrumental necessário para a construção de um modelo eficaz, apto a orientar a consecução dos valores sociais definidos no ordenamento jurídico. (...) Essa postura é consentânea com as origens do direito comercial, que não nasceu como uma criação abstrata, puramente teórica, mas surgiu como um direito autônomo de classe, fruto da prática consuetudinária dos comerciantes, com uma jurisdição especial, fundada na autonomia das corporações de ofício." (MUNHOZ, Eduardo Secchi. Empresa contemporânea e direito societário - poder de controle e grupos de sociedades. São Paulo: Juarez de Oliveira, 2002, p. 24)

${ }_{127}$ VERÇOSA, Haroldo Malheiros Duclerc. Curso de direito comercial. v. 2. $2^{\text {a }}$ ed. São Paulo: Malheiros, 2010, pp. 266-267
} 


\subsection{Nossa visão}

Para que este trabalho ganhe utilidade prática sem perder sua natureza acadêmica, separaremos nossa conclusão em duas perspectivas, a (i) conclusão prática representando nosso entendimento a partir do modelo posto (i.e., interpretação do que existe); e (ii) conclusão ideológica refletindo nossa visão de um modelo ideal a ser perseguido (i.e., eventuais acréscimos ou revisões ao modelo existente).

\subsubsection{Conclusão prática}

Antes de tecermos quaisquer comentários sobre o tema, fundamental pontuar o posicionamento da.

Como visto anteriormente, a teoria institucionalista da empresa acionária influenciou diversas legislações no mundo, especialmente a nossa. Não por outro motivo, encontramos diversas passagens institucionalistas na nossa lei, notadamente, os deveres atribuídos às duas fontes de poder da companhia. Dentre os deveres atribuídos, encontramos: o de (i) o acionista controlador (a) fazer com que a companhia cumpra sua função social ${ }^{128}$; (b) ter deveres para com os demais acionistas da empresa, os que nela trabalham e para com a comunidade em que atua a companhia ('a' e 'b' previstos no parágrafo único do art. 116 da LSA); e (c) não orientar a companhia para fim lesivo ao interesse nacional (art. 117, $\S 1^{\circ}$, alínea 'a', da LSA); e (ii) os administradores exercerem suas atribuições no interesse da companhia, satisfeitas as exigências do bem público ${ }^{129}$ e da função social da empresa (caput do art. 154 da LSA).

\footnotetext{
${ }^{128}$ CARVALHOSA afirma existirem três modernas concepções sobre a função social da empresa: "a primeira refere-se às condições de trabalho e às relações com seus empregados, em termos de melhoria crescente de sua condição humana e profissional, bem como de seus dependentes. A segunda volta-se ao interesse dos consumidores, diretos ou indiretos, dos produtos e serviços prestados pela empresa, seja em termos de qualidade, seja o que se refere aos preços. A terceira volta-se ao interesse dos concorrentes, a favor dos quais deve o administrador da empresa manter práticas equitativas de comércio, seja na posição de vendedor, como na de comprador. A concorrência desleal e o abuso do poder econômico constituem formas de antijuridicidade tipificadas." (CARVALHOSA, Modesto. Comentários à lei das sociedades anônimas. $5^{\mathrm{a}}$ ed. São Paulo: Saraiva, 2011. v. 3, p. 276, apud, PARENTE, Flávia. O dever de diligência dos administradores de sociedades anônimas. Rio de Janeiro: Renovar, 2005, pp. 136-137)

${ }^{129}$ (i) “A lei, ao referir-se a 'bem público', esta indicando que se leve em consideração 'o conjunto de valores do grupo social que podem ser afetados ou influenciados pela atividade empresarial" (CARVALHOSA, Modesto. Comentários à lei das sociedades anônimas. 5a ed. São Paulo: Saraiva, 2011. v. 3, p. 276, apud, PARENTE, Flávia. O dever de diligência dos administradores de sociedades anônimas. Rio de Janeiro: Renovar, 2005, pp. 136-137). (ii) Para VERÇOSA: "Pode-se dizer que o legislador, neste ponto da LSA,
} 
Respeitados juristas entendem que a LSA adotou um regime dual (institucionalista e contratualista $)^{130}$. A nosso ver, embora tais ensinamentos sejam pertinentes, entendemos que, do ponto de vista prático, seria inconcebível admitir o regime da dualidade. Tendo em vista as divergências entre as duas escolas, nas hipóteses de entrechoque (em que efetivamente interessa saber qual interesse deverá ser observado), a presença de elementos de caráter institucionalista (notadamente os previstos na LSA - mencionados no parágrafo

condena o chamado 'capitalismo selvagem', ou seja, aquele que busca o lucro a qualquer preço, independentemente dos efeitos negativos que a atividade empresarial possa gerar, especialmente os danos ao meio ambiente. O dispositivo vertente está em perfeita consonância com os princípios gerais da atividade econômica previstos no art. 170 da CF, especialmente nos incisos III (função social da propriedade), V (defesa do consumidor), VI (defesa do meio ambiente), VII (redução das desigualdades regionais e sociais) e VIII (busca do pleno emprego)" (VERÇOSA, Haroldo Malheiros Duclerc. Curso de direito comercial. v. 3. $2^{\mathrm{a}}$ ed. São Paulo: Malheiros, 2011, p. 465)

130 (i) CALIXTO SALOMÃo: "O sistema societário brasileiro é uma interessante demonstração dos resultados, não de todo coerentes, a que a convivência de ambas as teorias em um mesmo sistema positivo pode levar. Os princípios contratualistas permeiam o sistema de direito societário brasileiro (...). A lei acionária de 1976 introduz no ordenamento brasileiro objetivos diversos. O legislador tentou incentivar a grande empresa de duas maneiras diferentes: primeiro, o auxílio à concentração empresarial (...) Tentou-se, em segundo lugar, facilitar a capitalização das empresas através do mercado acionário. (...) Procurou-se criar um sistema de proteção das minorias acionárias, baseado, entre outras coisas, na institucionalização dos poderes e deveres do sócio controlador com relação aos demais acionistas da empresa, aos trabalhadores e à comunidade em que atua. (...). A esta tímida declaração de princípios teóricos seguram-se outras manifestações legislativas mais práticas, de nítido caráter contratualista.(...)", tal como "a nova função atribuída ao acordo de acionistas, verdadeira nova instância parassocietária de poder (...)" que tenta "dar prevalência ao interesse do grupo de sócios (...)". Ocorre que a declaração de princípios do artigo 116 não pode ser tida como vã. Representa a única declaração direta dos princípios a ordenarem o interesse social. Consequentemente, a análise das regras (...) deve ser temperada (...) pela perspectiva institucionalista (...).”(SALOMÃO FILHO, Calixto. O Novo Direito Societário. $4^{\mathrm{a}}$ ed. São Paulo: Malheiros, 2011, pp. 38-40); (ii) VALladÃO: “(...) a lei 6.404 estabeleceu um regime dual (ocupando o direito brasileiro posição singular nessa matéria, como adverte Comparato): ao acionista em geral não compete senão perseguir o interesse da companhia, vale dizer, o interesse comum dos sócios, uti socii, visto aqui, portanto, numa perspectiva contratualista, de disciplina dos interesses privados dos acionistas; ao acionista controlador é que compete, com arbitrium boni viri, a tutela dos interesses intra ou extra empresariais, ou seja, dos interesses dos demais acionistas e investidores, dos trabalhadores, da comunidade e da economia nacional, tutela esta, portanto, vinculada a uma perspectiva institucional da sociedade por ações." (FRANÇA, Erasmo Valladão Azevedo e Novaes. Conflito de Interesses nas assembleias de S.A. Malheiros, São Paulo: 1993, p. 56; e (iii) SAMPAIO CAMPOS: "Embora alguns autores sustentem que a LSA teria se filiado à corrente institucionalista, notadamente por conta das referência contidas no parágrafo único do artigo 116 e da própria redação do caput do artigo 154, que se refere a bem público e função social da empresa, essa afirmação é equivocada (...). Diga-se, aliás, que essas limitações não são caracterizadoras de uma visão institucionalista da companhia. Esses conceitos (...) estão disseminados na vida em sociedade e estão longe de ser exclusivos de uma visão de instituição. Atente-se, a propósito, que inclusive os contratos hoje se encontram sujeitos à observância de princípios análogos, como a função social (...) e da própria Constituição Federal. Por outro lado, a LSA possui diversas características próprias da tradicional visão contratualista da companhia, de que são exemplos a previsão de dividendo obrigatório e cuidadoso tratamento dado à constituição de reservas (...). A bem da verdade, a LSA já resolve grande parte da questão, já que contém em sua estrutura elementos característicos de ambas as teorias - o que levou, aliás, parte da doutrina a dizer que a LSA teria adotado um sistema dual (Comparato, 1995b, p. 86) - e deve ser interpretada e aplicada tal como pretendeu o legislador ao adotar essa posição singular. (...) O que se exige é que esses efeitos [bem público e função social] sejam considerados e avaliados, e que se busque adotar posição que, se não concilie esses interesses, ao menos cause o menor impacto." (SAMPAIO CAMPOS, Luiz Antonio. In BULHÕES PEDREIRA, José Luiz e LAMY FILHO, Alfredo (Coord.). Direito das Companhias. Vol. I. Rio de Janeiro: Forense, 2010, pp. 1112 e 1116) 
anterior - que são bastante amplos) faz anular o cunho contratualista da lei, razão pela qual somos da posição de que a LSA é uma lei institucionalista.

A própria lei já cuidou de estabelecer que o interesse social pode não ser coincidente com o dos acionistas, à medida que atribuiu o dever aos administradores de primeiro observar o interesse social, ainda que em prejuízo dos interesses dos acionistas que o elegeram.

Como se pode depreender da leitura conjunta dos artigos 115, 116 e 154 da LSA, entedemos que a LSA atribuiu deveres de cunho institucionalista somente às fontes de poder da companhia (o acionista controlador e os administradores) e não aos acionistas em geral. Tal construção, a nosso ver, é admirável à medida que seria tarefa árduo, para não dizer injusto, impor tais deveres àqueles que pouco podem opinar e influenciar na condução da atividade empresarial ${ }^{131}$.

O regime adotado pela LSA é condizente com os princípios norteadores da atividade econômica previstos na Constituição Federal $^{132}$, conforme a lição de VERÇOSA:

A função social da companhia coloca-se dentro de um contexto mais amplo de matriz constitucional, ou seja, a função social da propriedade. Desde muito tempo que a propriedade deixou de ser a expressão do individualismo egoístico, que vigorou até o começo

\footnotetext{
${ }^{131}$ Neste sentido os ensinamentos de VALLADÃO: "O status do controlador difere, aí, sensivelmente, da posição do não-controlador. Enquanto aquele tem deveres e responsabilidades não só em relação aos demais acionistas, mas também perante os trabalhadores e a comunidade em que atua a empresa, os nãocontroladores devem pautar sua atuação na companhia pelos interesses estritamente societários. É que uns são autênticos empresários, ao passo que os outros não passam de sócios capitalistas. Ora, o poder reconhecido pela lei ao empresário é, tecnicamente, uma função, não uma prerrogativa de gozo no interesse próprio, por isso que o controle não se confunde, de forma alguma, com a propriedade. O poder de voto do acionista não-controlador, ao contrário, assemelha-se à prerrogativa dominial. (FRANÇA, Erasmo Valladão Azevedo e Novaes. Conflito de Interesses nas assembleias de S.A. Malheiros, São Paulo: 1993, p. 65)

${ }^{132}$ A esse respeito nos ensina MUNHOZ: "Os valores sociais a serem necessariamente perseguidos pelo direito societário, no Brasil, estão enunciados primacialmente no art. 170 da Constituição Federal. (...) Segundo o art. 170, a ordem econômica tem por fim assegurar a todos 'existência digna, conforme os ditames da justiça social', fundando-se na 'valorização do trabalho humano' e na 'livre iniciativa'. Ainda segundo a norma constitucional, a ordem econômica deve observar os seguintes princípios: (i) soberania nacional; (ii) propriedade privada; (iii) função social da propriedade; (iv) livre concorrência; (v) defesa do consumidor; (vi) defesa do meio ambiente; (vii) redução de desigualdades regionais e sociais; (viii) busca pelo pleno emprego; e (ix) tratamento favorecido para as empresas de pequeno porte constituída sob as leis brasileiras e que tenham sua sede a administração no país. (...) São normas programáticas lato sensu, que atuam em três planos de eficácia: (i) prevalecem sobre a norma da lei ordinária, (ii) vinculam ações futuras do legislador, que deve veicular normas em conformidade com o programa de ação pré-estabelecido e (iii) vinculam a interpretação das demais normas." (MUNHOZ, Eduardo Secchi. Empresa contemporânea e direito societário - poder de controle e grupos de sociedades. São Paulo: Juarez de Oliveira, 2002, p. 28)
} 
do século passado, para apresentar uma utilização condicionada ao bem público. Há que se conciliar, portanto, o interesse privado dos acionistas de exercerem por meio da companhia uma atividade lucrativa, que lhes dará aos dividendos, com o interesse maior do corpo social, em uma harmonia que deverá se mostrar compatível com a gama de interesses em jogo. ${ }^{133}$

A inevitável crítica que se faz é sobre a eficácia de tais dispositivos institucionalistas previstos pela LSA. Sobre este aspecto é preciosa a lição de COMPARATO:

Cedemos aí, mais uma vez, à tradição jusnaturalista, de puras afirmações de princípio, sem o necessário implemento de remédios jurídicos sancionatórios. Pois, se o titular desses interesses comunitários e nacionais transborda largamente o círculo empresarial, quem tomará a iniciativa de defendê-los e com que tipo de ação? Certamente não os acionistas, mesmo que minoritários ou não controladores. $\mathrm{Na}$ formulação legal do mecanismo de responsabilidade civil, houve a definição de novos interesses protegidos e de novo responsável (o controlador), ao lado dos administradores. Mas não houve a indispensável designação do agente legitimado a agir em prol do bem público. ${ }^{134}$

Concluímos que nossa lei é sim institucionalista, de forma que, para observá-la, os poderes responsáveis pela condução da atividade empresarial (acionista e administração) deverão considerar os interesses não só dos acionistas, mas também de todos os stakeholders.

\footnotetext{
${ }^{133}$ VERÇOSA, Haroldo Malheiros Duclerc. Curso de direito comercial. v. 3. $2^{\mathrm{a}}$ ed. São Paulo: Malheiros, 2011, p. 289. O ilustre jurista (e, por sorte, nosso orientador) afirma ainda que: “(...) a atividade da empresa ultrapassa os limites internos, e ela deve atuar com uma finalidade social (cujo conteúdo não é explicado pelo legislador da LSA), devendo atender, neste plano, com o equilíbrio que for possível, além de aos acionistas que nela buscam lucro, aos empregados e à comunidade na qual atua. (...) Trata-se de equação muito difícil de resolver porque, no limite, os acionistas desejam o máximo de lucro e os empregados o máximo de benefícios, ambos a qualquer preço. Do outro lado, a comunidade deseja obter das companhias o maior índice de benefício que lhe possam proporcionar, com o mínimo de custo." (VERÇOSA, Haroldo Malheiros Duclerc. Curso de direito comercial. v. 3. $2^{\text {a }}$ ed. São Paulo: Malheiros, 2011, p. 524)

${ }^{134}$ COMPARATO. Controle Conjunto, abuso no exercício de voto acionário e alienação de controle empresarial, p. 301, apud, CUNHA, Rodrigo Ferraz Pimenta da. Estrutura de Interesses nas Sociedades Anônimas - Hierarquia e Conflitos. São Paulo: Quartier Latin, 2007, p. 162. MunHOZ também se manifestou sobre esse ponto: "note-se que, na lei acionária brasileira, a ação de responsabilidade por abuso de poder de controle fica restrita aos acionistas, o que permite concluir que a definição de novos interesses protegidos (dos trabalhadores, da comunidade local, da nação) não veio acompanhada da indispensável designação do agente legitimado para sua defesa." (MUNHOZ. Contribuições para revisão do modelo societário. 2002.360 f. Tese (Doutorado em Direito Comercial) - Faculdade de Direito, Universidade de São Paulo, São Paulo, 2002, apud, CUNHA, Rodrigo Ferraz Pimenta da. Estrutura de Interesses nas Sociedades Anônimas Hierarquia e Conflitos. São Paulo: Quartier Latin, 2007, p. 162)
} 
Como, em regra, um poder tende a prevalecer sobre o outro (no Brasil, o acionista controlador sobre a administração, na maioria dos casos), a solução para o atendimento do interesse social (institucionalista, a nosso ver) não passa por estabelecer quem está em melhores condições de arbitrá-lo ${ }^{135}$. Isso porque, na prática, tal decisão será tomada de acordo com a alocação do poder. Seria ilógico e utópico imaginar que, numa realidade em que prevalece um poder, outro poder inferior ditaria o interesse social. Assim, ao invés de eleger um árbitro (já o feito na prática), é preciso monitorar a atuação do poder prevalecente.

Em outras palavras, é preciso assegurar meios para que a LSA seja efetivamente cumprida e os outros interesses, além daqueles dos detentores do poder (acionistas ou administradores), sejam também atendidos. Nos capítulos posteriores detalharemos melhor essa questão, mas antecipamos que haveria pelo menos duas formas de fazê-lo sob o prisma da LSA: (i) interna, por meio da (a) criação de coexistência independente das duas fontes de poder da companhia (que passaria pela exigência de conselheiros independentes, uma nova formulação de suas funções, direitos e deveres e alteração de determinados dispositivos contraditórios à tal coexistência independente, e.g., eliminação dos $\S \S 8^{\circ}$ e $9^{\circ}$ do art. 118 da LSA), e (b) atribução de um agente (que não o acionista) legitimado a agir em prol do bem público ${ }^{136}$; e (ii) externa, pela melhoria da eficácia da LSA (enforcement) e do constante trabalho de criação e revisão de leis específicas de proteção aos interesses dos stakeholders.

Somente assim, entendemos que o interesse social (institucionalista), na forma prevista e imaginada pela LSA, passaria a ter condições de ser observado.

\footnotetext{
${ }^{135}$ Tal qual preconizado por alguns autores: "Se, por um lado, a Lei no 6.404/76 impõe a prevalência da decisão tomada pelos acionistas controladores signatários de acordos de acionistas arquivado, por outro exige que os administradores atuem em defesa do interesse social, ainda que este contrarie os interesses dos acionistas que os elegeram. É do entrechoque entre as normas do art. $118, \S \S 8^{\circ}$ e $9^{\circ}$, e aquelas do art. 154 da Lei $\mathrm{n}^{\circ} 6.404 / 76$ que surge a necessidade de (...) estabelecer quem - acionista controlador ou administrador esta em melhores condições de atuar como árbitro dos interesses da companhia.” (PATELLA, Laura Amaral; BORES, Leandro Vilarinho; BERNARDES, Lucas Petri; AZEVEDO, Luís André Negrelli de Moura. Deveres Fiduciários dos Administradores. Vinculação dos Administradores. In Mercado de Capitais Brasileiro: Doutrina, Cases e Materials. São Paulo: Quartier Latin, 2012, p. 233)

${ }^{136}$ Tal qual a ação de responsabilidade do (i) acionista controlador por abuso de poder de controle conferida aos acionistas (art. 117, LSA), bem como (ii) administrador conferida à companhia e, em determinados casos, aos acionistas (art. 159, LSA)
} 


\subsubsection{Conclusão ideológica}

Vale destacar que a posição assumida neste trabalho, de que o interesse social deve ser entendido sob o aspecto institucional, foi construída a partir de uma interpretação sistemática da LSA e dos princípios norteadores da atividade econômica estabelecidos pela Constituição Federal.

Do ponto de vista ideológico, todavia, confessamos nossa preferência pelo modelo da prevalência do acionista (shareholder primacy). A nosso ver, embora a LSA tenha nobremente tentado proteger os interesses dos stakeholders, após quase 40 anos de sua vigência, verifica-se a ineficácia de tal intenção.

O balanço é ineficiente, já que os interesses dos stakeholders dispostos na LSA não puderam ser efetivamente atendidos, tampouco monitorados, em vista da ausência de um agente capaz para, em defesa do bem público, responsabilizar o acionista controlador por abuso de controle ou a administração por meio da ação de responsabilidade. De quebra, temos convivido com princípios e normas abertas de difícil interpretação e consenso.

Não se pretende, com isso, negar os efeitos irradiantes da sociedade anônima que claramente ultrapassam a camada de acionistas para afetar os stakeholders, mas sim transferir a proteção de tais interesses ao Poder Judiciário e a legislações específicas e conhecedoras das idiossincrasias de cada ente afetado.

O efetivo monitoramento interno (pela teoria orgânica) e externo (pelo Poder Judiciário) $^{137}$ da fonte de poder prevalecente da sociedade anônima (acionistas ou administração, conforme a estrutura de propriedade adotada pela companhia), e, portanto, responsável pela condução da atividade empresarial, bem como a existência de boas leis específicas de proteção dos interesses dos stakeholders resultariam em uma melhor observância e organização de todos estes interesses envolvidos na prática da atividade empresarial.

\footnotetext{
137 “(...) o que se ressente em nosso direito não são apenas regras de direito (posto que, conquanto possam e devam ser aprimoradas em pontos de estrangulamento, elas já existem); o que falta, sobretudo, é o exercício, a efetivação, a real concretização delas, rompendo, dessa forma, a prolongada inércia do acionariado brasileiro." (ADAMEK, Marcelo Vieira. Responsabilidade civil dos administradores de S/A e as ações correlatas. São Paulo: Saraiva, 2009, pp. 5 e 6).
} 
Mas, a recepção constitucional, legislativa e jurisprudencial e os consequentes custos de tamanha modificação ideológica serim inviáveis, razão pela qual somos da opinião de que é preciso (e temos condições para tanto) buscar soluções a partir de nosso modelo jurídico-societário. Este trabalho foi, pois, todo elaborado sob essa concepção. 


\section{O PODER DO ACIONISTA EM FOCO}

Apresentada a sociedade anônima como objeto de estudo e o interesse social como balizador da atuação do condutor da atividade empresarial, analisaremos cada uma das potenciais fontes de poder.

Este capítulo é dedicado ao poder do acionista ${ }^{138}$ em si e tem por foco a sua organização sob a forma concentrada ${ }^{139}$, já que, somente assim, ele terá condições de prevalecer sobre o poder da administração, na condução da atividade empresarial ${ }^{140}$ (muito embora tenhamos analisado, também, a possibilidade de acionistas minoritários vincularem a atuação de conselheiros por eles indicados por meio de acordos de minoria e eleição em separado).

Este estudo é fundamental, na medida em que a possibilidade de o poder do acionista de, legitimamente, vincular o poder da asministração passa pelo entendimento de como se organiza aquele poder e a quais valores ele se submete ${ }^{141}$.

\footnotetext{
138 "Da perspectiva econômica, essa alocação de poder apoia-se nas seguintes premissas: (i) o proprietário do bem é aquele que lhe atribui maior valor ou lhe confere o uso mais produtivo; (ii) o estímulo ao investimento depende da possibilidade de o investidor controlar e determinar o destino do objeto de seu esforço e de sua criação; (iii) o acionista é titular de uma pretensão residual contra a sociedade, pois somente recebe valor depois de adimplidas as demais obrigações, ou seja, de atendidas as demais pretensões (fixas) detidas contra a empresa (credores, fornecedores e trabalhadores), o que o estimula a dirigi-lo no sentido de consecução de sua função social (crescimento com rentabilidade). No campo jurídico, a atribuição do poder empresarial ao acionista decorre do direito de propriedade, ainda que se trate no caso de uma propriedade dinâmica, e não estática (...)". (MUNHOZ, Eduardo Secchi. Quem deve comandar a companhia? Alocação do poder empresarial: sistema de freios e contrapesos. In Estudos em Homenagem a Modesto Carvalhosa. São Paulo: Saraiva, 2012, p. 508) Vale, ainda, o comentário de CALIXTO SALOMÃo a seguir sobre conveniência de adoção do modelo concentrado: "Parte da doutrina vê na concentração de poder de controle, uma forma de diminuir os agency costs (custos de supervisão) e dessa forma melhorar o desempenho da sociedade. Não é fácil discutir essa posição em bases puramente teóricas. A razão principal está na impossibilidade de mensuração e comparação dos 'custos de supervisão' e seus efeitos sobre o funcionamento 'eficiente' da sociedade com os 'custos do abuso e do conflito' por parte do controlador absoluto na sociedade." (SALOMÃO FILHO, Calixto. O Novo Direito Societário. $4^{a}$ ed. São Paulo: Malheiros, 2011, pp. 57-58)

139 "No modelo de capital concentrado não se discute que o poder empresarial é conferido ao acionista titular da maioria do capital votante. $\mathrm{O}$ acionista controlador (...) tem a prerrogativa de estabelecer os rumos do empreendimento empresarial." (MUNHOZ, Eduardo Secchi. Quem deve comandar a companhia? Alocação do poder empresarial: sistema de freios e contrapesos. In Estudos em Homenagem a Modesto Carvalhosa. São Paulo: Saraiva, 2012, pp. 507-508)

140 "O direito, porém, não desconhece essa realidade e não sanciona a existência do poder em si, até mesmo porque ele é indispensável ao funcionamento das companhias. O que ele faz, na verdade, é procurar conformar o exercício desse poder, de modo a cumprir a função que legislativamente se lhe imprimiu, para assim não se transformar em tirania e fonte de lesão a outros interesses igualmente relevantes e dignos de tutela (...)". (ADAMEK, Marcelo Vieira. Responsabilidade civil dos administradores de S/A e as ações correlatas. São Paulo: Saraiva, 2009, pp. 5 e 6)

${ }^{141}$ COMPARATO. Controle Conjunto, abuso no exercício de voto acionário e alienação de controle empresarial, p. 301, apud, CUNHA, Rodrigo Ferraz Pimenta da. Estrutura de Interesses nas Sociedades
} 
Em outras palavras, pretendemos, a seguir, verificar os limites do acordo de acionistas e do princípio da soberania da assembleia geral, para que, posteriormente, possamos compará-los com os deveres fiduciários e os princípios atribuídos ao poder da administração. Só, então, responderemos ao questionamento objeto deste trabalho.

\title{
4.1. O acordo de acionistas
}

\subsubsection{Conceito, histórico e panorama}

\author{
Nas palavras de EIZIRIK:
}

O acordo de acionistas constitui um contrato celebrado entre acionistas de determinada companhia visando à composição de seus interesses individuais e ao estabelecimento de normas de atuação na sociedade, harmonizando seus interesses próprios ao interesse social. $^{142}$

O acordo de acionistas não era regulado pelo decreto-lei 2.627, de 1940, todavia, referido diploma também não proibia sua contratação. Tal lacuna dividiu a doutrina ${ }^{143}$ por

Anônimas - Hierarquia e Conflitos. São Paulo: Quartier Latin, 2007, p. 162. MUNHOZ também se manifestou sobre esse ponto: "note-se que, na lei acionária brasileira, a ação de responsabilidade por abuso de poder de controle fica restrita aos acionistas, o que permite concluir que a definição de novos interesses protegidos (dos trabalhadores, da comunidade local, da nação) não veio acompanhada da indispensável designação do agente legitimado para sua defesa." (MUNHOZ. Contribuições para revisão do modelo societário. 2002. 360 f. Tese (Doutorado em Direito Comercial) - Faculdade de Direito, Universidade de São Paulo, São Paulo, 2002, apud, CUNHA, Rodrigo Ferraz Pimenta da. Estrutura de Interesses nas Sociedades Anônimas Hierarquia e Conflitos. São Paulo: Quartier Latin, 2007, p. 162)

${ }^{142}$ EIZIRIK, Nelson. A Lei das S.A. Comentada. Volume II - Arts. 121 a 188. São Paulo: Quartier Latin, 2011, p. 702. BARBI FILHO, por sua vez, assim o define: "contrato entre acionistas de uma mesma companhia, distinto de seus atos constitutivos, e que tem como objeto o exercício dos direitos decorrentes da titularidade das ações' (BARBI FILHO, Celso. Acordo de Acionistas. Belo Horizonte: Del Rey, 1993, p. 42) Por fim, destacamos a definição de CARVALHOSA: "Trata-se, o acordo de acionistas, de um contrato submetido às normas comuns de validade e eficácia de todo o negócio jurídico privado, concluído entre acionistas de uma mesma companhia, tendo por objeto a regulação do exercício dos direitos referentes às suas ações, tanto no que concerne ao controle como ao voto dos minoritários ou, ainda, à negociabilidade dessas ações." (CARVAlHOSA, Modesto. Acordo de Acionistas. São Paulo: Saraiva, 2011, p. 21)

143 (i) PONTES DE MIRANDA "entendia poder o acionista, dentro do princípio do livre exercício do voto, comprometer-se a votar de determinada maneira." (Tratado, cit., v. 50, p. 302 e s. e 395 e s., apud, CARVAlHOSA, Modesto. Comentários à lei das sociedades anônimas. v. 2. $5^{\mathrm{a}}$ ed. São Paulo: Saraiva, 2011, p. 657); (ii) Nas palavras de CARVAlHOSA: "Dessa maneira, as convenções de voto seriam válidas e eficazes, no regime do Decreto-Lei n. 2.627, de 1940, não vinculando, porém, a sociedade, como referido." (CARVAlHOSA, Modesto. Comentários à lei das sociedades anônimas. v. 2. $5^{\mathrm{a}}$ ed. São Paulo: Saraiva, 2011, p. 657). VALVERDE (1959, v. II, n. 401), por sua vez, “(...) concluía ser recomendável examinar o caso a caso as convenções de voto, para verificar se consultavam os interesses da companhia e se admitiam a 
muito tempo, até que a prática empresarial importou e consolidou esse costume no Brasil $^{144}$.

Como resultado, à época da promulgação da LSA, o legislador não poderia deixar de regular esta nova realidade contratual $^{145}$ que, segundo a exposição de motivos ${ }^{146}$, consistia em um intermediário entre os (indesejáveis) acordos ocultos e a adoção de holdings como forma de organização do poder do acionista.

Mais à frente, a lei 10.303 , de $2001^{147}$, realizou importantes modificações ao instituto. Entre elas, incluiu mais um possível (e subjetivo) objeto aos acordos no caput do art. 118 - o exercício do poder de controle, bem como inseriu os $\S \S 8^{\circ}$ e $9^{\circ}$ ao art. $118^{148}$.

desvinculação do acionista em condições razoáveis (LOBO, Carlos Augusto da Silveira. BULHÕES PEDREIRA, José Luiz; LAMY FILHO, Alfredo (Coord.). In Direito das Companhias. v. I. Rio de Janeiro: Forense, 2010, pp., 453-454); e (iii) Em sentido contrário, manifestou-se CunHA PEIXOTO, pois de acordo com referido autor as convenções de voto representavam "a derrogação do princípio de ordem pública representado, na espécie, pela prerrogativa do acionista de deliberar livremente em assembleia." (Sociedade por ações, cit., v. 2, p. 354 e s., apud CARVALHOSA, Modesto. Comentários à lei das sociedades anônimas. v. 2. $5^{\mathrm{a}}$ ed. São Paulo: Saraiva, 2011, p. 657)

144 "A corrente favorável encarou a realidade e as mudanças que a estrutura das relações na sociedade anônima vinha sofrendo, em especial pela alteração da escala empresarial. Daí decorreu, com efeito, a necessidade de se organizarem grandes companhias, em que o domínio acabou sendo exercido por parcela minoritária do capital, diante do fracionamento e atomização do colégio acionário." (CARVALHOSA, Modesto. Comentários à lei das sociedades anônimas. v. 2. $5^{\mathrm{a}}$ ed. São Paulo: Saraiva, 2011, p. 658)

145 Nas palavras de SZTAJN: "O legislador de 1976, atento à prática e desejoso de estimular a 'desintermediação' financeira na capitalização das companhias brasileiras, entendeu que admitir acordos de acionistas facilitaria a abertura das sociedades familiares que eram a maioria das sociedades existentes à época. A possibilidade de interferir no sentido do voto dos eventuais ingressantes mantinha o controle nas mãos dos membros da família ou grupo de fundadores, estimulando a recepção de capitais. Incluir no acordo de voto a relação das matérias que fossem relevantes para manter a estabilidade do controle, a segurança de que não haveria alteração brusca das diretrizes administrativas, tornava mais palatável a ampliação da base acionária." (SZTAJN, Rachel. Acordo de Acionistas. In SADDI, Jairo (Org.). Fusões e Aquisições: Aspectos Jurídicos e Econômicos. São Paulo: IOB, 2002., pp. 285-286) Continua a autora: "A discussão da lei do anonimato nos anos 70 do século passado deixava claro que seu escopo era estimular o desenvolvimento do mercado de valores mobiliários, promover o direcionamento da poupança privada para investimentos produtivos e de risco, fomentando a 'desintermediação financeira. (...) A recepção dos acordos de acionista, notadamente os de voto, é parte desse processo, visando, creio, facilitar a busca dos recursos com o público, mantendo uma certa estabilidade na definição das diretrizes administrativas." (SZTAJN, Rachel. Acordo de Acionistas. In SADDI, Jairo (Org.). Fusões e Aquisições: Aspectos Jurídicos e Econômicos. São Paulo: IOB, 2002., p. 293)

146 “(...) modalidade contratual de prática intensa (...) da maior importância para a vida comercial” e um intermediário entre a "holding' (solução esta que possui a inconveniência da transferência definitiva das ações para outra sociedade) e o acordo oculto". (Mensagem n 204/1976 do Poder Executivo, Exposição de Motivos 196, de 24 de junho de 1976)

147، (...) Entre as emendas do Senado estavam as supressivas dos aludidos $\S \S 8^{\circ}$ e $9^{\circ}$ do art. 118. Uma delas, a apresentada pelo Senador Paulo Hartung, suprimia ambos os dispositivos, enquanto a outra, da lavra do Senador Íris Rezende, só retirava do texto o $\$ 9^{\circ}$. Essas emendas supressivas, no entanto, lamentavelmente não deram origem a nenhum veto presidencial." (SALLES DE TOLEDO, Paulo F. C. Modificações Introduzidas na Lei das Sociedades por Ações, quanto à Disciplina da Administração das Companhias. In LOBO, Jorge (Coord.). Reforma da Lei das Sociedades Anônimas. $2^{\text {a }}$ ed. Rio de Janeiro: Forense, 2002, p. 428) 
O acordo de acionistas é o instrumento amplamente utilizado pela prática empresarial $^{149}$ de organização e de harmonização do poder do acionista, seja ele majoritário ou minoritário. Pode regular (i) o poder de controle das mais variadas formas (desde a formação e relacionamento entre os participantes de blocos de comando, jointventures, até o relacionamento com investidores minoritários estratégicos - vide a indústria de private equity), bem como (ii) a reunião de minorias para criação e fortificação de determinados direitos ${ }^{150}$.

${ }^{148}$ Lembrando algumas lições a seguir sobre matérias que não podem ser passíveis de acordo de acionistas: (i) "O acordo de acionistas não pode predeterminar o voto sobre as declarações de verdade, aquele que é meramente declaratório da legitimidade dos atos dos administradores, restringindo-se ao voto no qual se emita declaração de vontade. (...) Não se pode permitir a predeterminação do voto sobre as declarações de verdade, pois, tratando-se de forma de fiscalização dos atos de administração, não deve ser exercida nos interesses de determinado grupo de acionistas" (REsp n ${ }^{\circ}$ 1.152.849/MG, 2009/0157602-6, Rel. Min. João Otávio Noronha, j. em 07.11.2013); (ii) “(...) O que conflita com a lei é a obrigação assumida pelo acionista de votar segundo decisão de terceiro. Assim, os acordos de acionistas não se prestam à cessão do direito de voto, mas apenas a regular o seu exercício - sendo, pois, nulo, por exemplo, o ajuste no qual um acionista cede a outrem o seu direito de voto ou se obriga a aprovar todas as propostas do controlador." (LAZZARESCHI NETO, Alfredo Sérgio. Lei das Sociedades por Ações Anotada. São Paulo: Saraiva, 2012, p. 276); (iii) "Vale lembrar que o exercício do direito de voto ou sua abstenção em contrapartida de vantagens patrimoniais (venda ou tráfico do voto) é conduta ilícita tipificada pelo Código Penal: 'Incorre na pena de detenção, de 6 (seis) meses a 2 (dois) anos, e multa, o acionista que, a fim de obter vantagem para si ou outrem, negocia o voto nas deliberações de assembleia geral.' (art. 177, $\S \S 2^{\circ}$ )". (SALOMÃO FILHO, Calixto. O Novo Direito Societário. $4^{a}$ ed. São Paulo: Malheiros, 2011, p. 136); (iv) "é vedado ao acordo de acionistas o chamado 'voto de verdade', como, por exemplo, aquele que aprova as contas da administração (...) Segundo a doutrina, dependendo do objeto da opinião a ser emitida, haverá um ato de 'verdade' ou de 'vontade', sendo que somente este último é autorizado ao acordo de acionistas, independentemente da previsão contratual em contrário. Neste caso, haveria típica ilicitude, representada pela convenção de voto a favor dos atos da administração e fiscalização da companhia. Será, em consequência, nulo o voto dado sobre essas matérias, desde que se originem de acordo de acionistas. A nulidade, na espécie, é formal, independentemente, portanto, da prova de conluio ou favorecimento. O voto exercido dessa forma simplesmente inexistiu, já que não representou a livre manifestação da vontade do acionista, que é imprescindível no caso." (TJMG, $13^{\circ}$ Cam., AC 1002405751312-9/002, Rel. Des. Eulina do Carmo Almeida, j. 15.5.2008, apud, LAZZARESCHI NETO, Alfredo Sérgio. Lei das Sociedades por Ações Anotada. São Paulo: Saraiva, 2012, p. 276); (v) “(...) o acordo de acionistas não pode dispor sobre poderes de representação dos administradores, competência do conselho de administração e da diretoria, dividendo mínimo, porquanto essas matérias são próprias do estatuto social e da lei. Ressalte-se que o acordo de acionistas apenas regula o exercício dos direitos decorrentes da lei e do estatuto, podendo, por exemplo, alterar o exercício do direito de voto, mas não modificar o próprio conteúdo do direito." (LAZZARESCHI NETO, Alfredo Sérgio. Lei das Sociedades por Ações Anotada. São Paulo: Saraiva, 2012, p. 275)

${ }^{149}$ Vide o já mencionado excelente trabalho produzido por GORGA e GELMAN (GORGA, Érica; GELMAN, Marina. O Esvaziamento Crescente do Conselho de Administração como Efeito da Vinculação de seu Voto a Acordos de Acionistas no Brasil. Prêmio IBGC Itaú Academia e Imprensa, 2012, pp. 10-11), o qual identificou, tambémm que de 181 companhias listadas nos segmentos especiais de governança da BM\&FBovespa, em maio de 201, (i) 107 possuíam acionista com menos de 50\% do capital votante, das quais 55 estavam sujeitas a acordos de acionistas; e (ii) 74 companhias possuíam acionista com mais de $50 \%$ do capital votante, das quais 35 estavam sujeitas a acordos de acionistas; totalizando, portanto, 90 companhias (de 181) sujeitas a acordos de acionistas no ambiente dos segmentos especiais da BM\&FBovespa.

${ }^{150}$ Vide a lição de CARVALHOSA: "Visa, com efeito, essa organização da minoria contrabalançar o poder de controle, estabelecendo um contraponto de forças e de interesses (...). Nesse aspecto, são chamados 'acordos de defesa'." (CARVALHOSA, Modesto. Acordo de Acionistas. São Paulo: Saraiva, 2011, pp. 263-264) 
Por nascer da fonte proprietária (do acionista), na prática, acaba por adentrar na estrutura orgânica da companhia ${ }^{151}$ e interferir diretamente na atuação dos demais órgãos ${ }^{152}$, muito embora, sob a ótica teórica, sua natureza parassocietária (acessória) ${ }^{153}$ sugira uma conformação à estrutura e não sua transformação ${ }^{154}$.

\author{
Prova disso é o fato de doutrinadores de respeito (como CARVALHOSA ${ }^{155}$ e \\ EIZIRIK $^{156}$ ) classificarem a comunhão de controle (organizada em reunião prévia ${ }^{157}$ ) \\ resultante de acordo de acionistas (de controle) como um novo órgão societário.
}

${ }^{151}$ Segundo SZTAJN: "Fato é que os acordos, embora estranhos ao estatuto, podem modificar algumas das regras ali predispostas quanto a sua aplicação às partes acordantes, o que não os transforma em ilegais ou contrários às normas. $\mathrm{O}$ resultado nesses casos é apenas a não-produção de efeitos contra terceiros podendo ser invocado entre as partes e entre estas e a companhia quando devidamente arquivado na sede social. A disciplina é similar àquela das sociedades em que o contrato ainda não tenha sido levado a registro." (SZTAJN, Rachel. Acordo de Acionistas. In SADDI, Jairo (Org.). Fusões e Aquisições: Aspectos Jurídicos e Econômicos. São Paulo: IOB, 2002., p. 276)

152 "O controlador não encontra na lei societária brasileira obstáculos, ainda que meramente formais ou procedimentais, para fazer valer suas decisões. Pode agora, após a última reforma societária (Lei 10.303, de 30 de outubro de 2001), mais do que nunca organizar seu poder através do acordo de acionistas, tendo sido o caput do artigo 118 da lei societária modificado exclusivamente para deixar mais claro aquilo que já era amplamente reconhecido, i.e., que é possível organizar o poder de controle através do acordo de acionistas. De outro lado dispõe de órgãos por ele totalmente controlados para exercer o seu poder, inclusive sobre a administração (o Conselho de Administração (...)). Finalmente, os direitos conferidos à minoria são típicos de um minoritário externo, sempre estimulado a retirar-se da sociedade e que é pouco ou nada protegido contra o conflito de interesses do controlador (...)" (SALOMÃO FILHO, Calixto. O Novo Direito Societário. $4^{\mathrm{a}}$ ed. São Paulo: Malheiros, 2011, p. 99)

${ }^{153}$ EIZIRIK, Nelson. A Lei das S.A. Comentada. Volume II - Arts. 121 a 188. São Paulo: Quartier Latin, 2011, p. 702. BARBI FILHO, por sua vez, assim o define: "contrato entre acionistas de uma mesma companhia, distinto de seus atos constitutivos, e que tem como objeto o exercício dos direitos decorrentes da titularidade das ações". (BARBI FILHO, Celso. Acordo de Acionistas. Belo Horizonte: Del Rey, 1993, p. 42) Por fim, destacamos a definição de CARVAlHOSA: "Trata-se, o acordo de acionistas, de um contrato submetido às normas comuns de validade e eficácia de todo o negócio jurídico privado, concluído entre acionistas de uma mesma companhia, tendo por objeto a regulação do exercício dos direitos referentes às suas ações, tanto no que concerne ao controle como ao voto dos minoritários ou, ainda, à negociabilidade dessas ações." (CARVALHOSA, Modesto. Acordo de Acionistas. São Paulo: Saraiva, 2011, p. 21)

${ }^{154}$ Vide os ensinamentos de VERÇOSA nesse sentido: "Os acordos em tela apresentam a natureza jurídica de contratos parassociais, ou seja, acordos paralelos aos das sociedades a que se referem, com os quais não se confundem, mas concomitantemente dependentes do contrato ou estatuto social. (...) Na condição de contrato acessório, o acordo de sócios não pode afetar diretamente o contrato principal, mas é por este condicionado nos seus limites." (VERÇOSA, Haroldo Malheiros Duclerc. Curso de direito comercial. v. 2. $2^{\mathrm{a}}$ ed. São Paulo: Malheiros, 2010, p. 177) Assim como as lições de CAliXto SAlomão: "De sua característica parassocial decorre a impossibilidade destes modificarem a relação social. Podem apenas modificar as relações entre as partes, em certos casos com força vinculante para a sociedade. (...) Claro está, como de resto já observado, que como instrumento de organização de instância parassocietária o acordo de acionistas não pode contrariar a própria estrutura societária. Portanto, e essa observação é óbvia, não é admissível qualquer acordo que possa, de maneira direta ou indireta, ferir estatutos sociais ou lei." (SALOMÃO FILHO, Calixto. O Novo Direito Societário. $4^{\mathrm{a}}$ ed. São Paulo: Malheiros, 2011, p. 128 e 139)

155 "O acordo de controle constitui o instrumento do exercício coletivo do poder-dever de levar a companhia a cumprir o seu objeto social. E, por isso, a comunhão de controle reveste a função de um órgão social, na medida em que seu exercício se dá tanto no âmbito dos órgãos da administração, como no da assembleia geral." (grifos nossos) (CARVALHOSA, Modesto. Acordo de Acionistas. São Paulo: Saraiva, 2011, p. 41)

156 "Com a reforma da legislação societária, ocorrida com a promulgação da Lei n. 10.303/01, o tratamento dado aos acordos de acionistas, visando a sua maior eficácia, consagrou um novo órgão, de fundamental importância para a tomada de decisões, que é o das 'reuniões prévias', usualmente previstas em tais acordos. 
Ademais, não é por outro motivo que nos propusemos a estudar o objeto deste trabalho, qual seja, o limite de interferência do acordo de acionistas (poder do acionista) sobre a administração (poder da adminstração) ${ }^{158}$.

\subsubsection{Objeto}

Da forma atualmente prevista pela LSA, nos termos do art. 118 da LSA, os acordos de acionistas (i) poderão ter por objeto ${ }^{159}$ a compra e venda de ações da companhia, preferência para adquiri-las, exercício do direito a voto e o poder de controle; e (ii) deverão ser observados pela companhia quando arquivados em sua sede ${ }^{160}$.

(...) Daí decorre uma estabilização do poder de controle nas reuniões prévias realizadas entre os signatários do acordo firmado entre acionistas controladores." (destaques nossos) (EIZIRIK, Nelson. Acordo de acionistas regulando o exercício do poder de controle. Interpretação dos $\$ 8^{\circ}$ e $9^{\circ}$ do art. 118 da Lei das S.A.. In Estudos de Direito Empresarial. São Paulo: Saraiva, 2010, pp. 31-32)

${ }^{157}$ A fim de implementar a convenção de voto, os acionistas reúnem-se previamente à assembleia geral (e, em muitos casos, também antes de reuniões de órgãos da administração), para determinar o direcionamento do voto em bloco. Com isso, há um consenso doutrinário de que a reunião prévia resultou no esvaziamento da assembleia geral, que, em regra, apenas formaliza o que já foi previamente acordado sobre o tema. Vejamos as opiniões de VerÇOSA e CARVALHOSA, respectivamente, sobre o tema: (i) "As reuniões prévias não são objeto de tutela legal, observando-se frequentes problemas delas originados, nas quais se pode verificar, de um lado, a presença da vontade do controlador em tomar certas decisões anteriormente à realização da assembleia-geral ou da realização da reunião do conselho de administração, a serem nelas objeto do voto dos participantes do acordo de acionistas, e, de outro lado, o interesse da companhia, verificado a partir das normas estatutárias. Mas, tendo em conta o funcionamento do acordo de acionistas, as reuniões prévias constituíram-se em um novo órgão societário, de natureza contratual. As deliberações nelas tomadas não são efetivamente vinculadoras da sociedade quando examinadas no interior do aludido órgão. Mas passam a ter eficácia externa quando o acordo de acionistas que as gerou é posto a funcionar no órgão societário adequado (conselho de administração ou assembleia-geral), uma vez cumpridas as formalidades previstas na lei condicionadoras deste efeito." (VERÇOSA, Haroldo Malheiros Duclerc. Curso de direito comercial. v. 3. $2^{\text {a }}$ ed. São Paulo: Malheiros, 2011, p. 334); (ii) "A lei 10.303, de 201, ao introduzir o exercício do poder de controle como objeto do acordo de acionistas, retira de fato os poderes da assembleia geral, na medida em que as deliberações sociais são tomadas pela comunhão dos controladores em reunião prévia. (...) Há com efeito um esvaziamento das funções da assembleia geral, a partir da vigência da lei $n$. 10.303, de 2001. Passa ela a ser órgão meramente homologatório." (CARVALHOSA, Modesto. Comentários à lei das sociedades anônimas. v. 2. $5^{\text {a }}$ ed. São Paulo: Saraiva, 2011, p. 756)

${ }_{158}$ Vide nossas conclusões ao longo, e especialmente, ao final desta dissertação.

${ }^{159}$ Sem antecipar a discussão sobre sua natureza jurídica, vale mencionar o comentário de CARVALHOSA sobre a sujeição do acordo de acionistas às regras gerais de existência, validade e eficácia de todo negócio jurídico: "Os acordos de acionistas deverão preencher os requisitos de validade exigidos para qualquer negócio jurídico, e que são, em nosso Direito, agente capaz, objeto lícito e forma prescrita ou não defesa em lei, consoante o art. 104 do Código Civil." (CARVALHOSA, Modesto. Acordo de Acionistas. São Paulo: Saraiva, 2011, p. 22)

${ }^{160}$ Destacamos a seguir algumas contribuições sobre o arquivamento do acordo de acionistas na sede da companhia: (i) "Perante a sociedade e terceiros, somente será eficaz o acordo depois de arquivado um exemplar de seu inteiro teor e anexos na sede social. A averbação far-se-á no livro próprio: registro de ações nominativas (afl. Instr. 2004.002.07499, Rel. Des. Bernardo Moreira Garcez Neto, da $10^{\mathrm{a}}$ Câm. Cív. Do TJRJ, j. em 8-6-2004). No caso de ações escriturais, caberá à instituição financeira encarregada proceder às anotações devidas nos seus livros e no extrato da conta corrente fornecido ao acionista (art. 40), podendo adotar o sistema de código. As averbações farão simples referência ao respectivo acordo, à sua data e ao 
Conforme os ensinamentos de VerçosA, outras matérias podem ser objeto de acordos de acionistas, dada sua natureza privada; porém, a eficácia externa é garantida somente àquelas taxativamente previstas no caput do art. 118 da LSA $^{161}$. Assim, eventual inadimplemento de outras matérias (não previstas no art. 118) será capaz de apenas resultar em perdas e danos, mas não, e.g., em execução específica ( $\S 3^{\circ}$ do art. 118) ou autotutela $\left(\S \S 8^{\circ}\right.$ e $9^{\circ}$ do art. 118).

Tendo em vista o escopo deste trabalho, concentraremos nossa análise aos dois tipos de acordo de acionistas que podem interferir na estrutura administrativa da companhia, quais sejam, os acordos de controle e de minoria. Não estudaremos os acordos ${ }^{162}$ de bloqueio, destinados a regular a compra e venda de ações ou preferência para adquiri-las).

\subsubsection{Acordo de controle}

Conforme antecipado acima, consta do caput do art. 118 da LSA, o exercício do poder de controle como um dos possíveis objetos de acordo de acionistas. Para muitos autores, tal inserção foi inócua, em vista de já constar anteriormente o direito de voto como objeto do acordo ${ }^{163}$.

objeto específico: patrimonial (preferência ou opção), de controle ou de voto minoritário." (CARVALHOSA, Modesto. Acordo de Acionistas. São Paulo: Saraiva, 2011, p. 49); (ii) "(...) Obrigatoriedade de averbação pela companhia, que não pode exercer juízo de valor quanto ao seu conteúdo (TJRJ, $18^{\circ} \mathrm{Cam}$. AC 2004.001.05257, Rel. Des. Carlos Eduardo Passos, j. 6.4.2004, apud, LAZZARESCHI NETO, Alfredo Sérgio. Lei das Sociedades por Ações Anotada. São Paulo: Saraiva, 2012, p 289); e (iii) “(...) feito o arquivamento sem que tenha sido feita a averbação, deverá o presidente da assembleia ou do órgão colegiado de deliberação da companhira, em cumprimento ao acordo de voto, cumprir o disposto nos parágrafos $8^{\circ} \mathrm{e} 9^{\circ}$, sem que se possa alegar a falta de averbação. Mas, o contrário já não é verdadeiro, ou seja, se há, como visto, arquivamento sem averbação, não pode haver averbação sem arquivamento. Como disse Celso Barbi Filho, o arquivamento constitui premissa da averbação." (LUCENA, José Waldecy. Das sociedades anônimas comentários à lei (arts. $1^{\circ}$ a 120). Vol. 1. Rio de Janeiro: Renovar, 2009, p. 1.173)

161 “(...) A lei estabeleceu eficácia plena de acordos de acionistas perante a sociedade quando restritos às matérias nela especialmente indicadas. (...) As matérias suscetíveis de obtenção de eficácia externa ficam restritas à compra e venda de ações; à preferência para a aquisição de ações entre os signatários; ao exercício do direito de voto; e ao exercício do poder de controle. (...) Outras matérias podem ser objeto de acordos, mas despidas de eficácia exerna. (...) A condição para a eficácia externa está no arquivamento do acordo na sede da companhia, e a oponibilidade a terceiros das obrigações e ônus correspondentes começa a ocorrer depois de averbado nos livros de registro da companhia e nos certificados de ações, quando emitidos." (VERÇOSA, Haroldo Malheiros Duclerc. Curso de direito comercial. v. 2. $2^{\mathrm{a}}$ ed. São Paulo: Malheiros, 2010, p. 175)

${ }^{162} \mathrm{Na}$ maioria dos casos, ao invés de um acordo isoladamente de bloqueio, as partes convencionam cláusulas de bloqueio dentro de acordos de controle ou de minoria.

${ }^{163}$ SZTAJN pauta-se, ainda, em outros argumentos: "No caput [do art. 118] acresceu-se expressão que contempla o exercício do poder de controle ao lado das alternativas consideradas em 1976. Não haveria 
Ao que nos importa neste trabalho, a partir de 2001, ao art. 118 da LSA foram adicionados os seguintes $\S \S 8^{\circ}$ e $9^{\circ}$, determinando que:

$\S 8^{\circ}$ O presidente da assembléia ou do órgão colegiado de deliberação da companhia não computará o voto proferido com infração de acordo de acionistas devidamente arquivado. ${ }^{164}$

$\S 9^{\circ} \mathrm{O}$ não comparecimento à assembléia ou às reuniões dos órgãos de administração da companhia, bem como as abstenções de voto de qualquer parte de acordo de acionistas ou de membros do conselho de administração eleitos nos termos de acordo de acionistas, assegura à parte prejudicada o direito de votar com as ações pertencentes ao acionista ausente ou omisso e, no caso de membro do conselho de administração, pelo conselheiro eleito com os votos da parte prejudicada. ${ }^{165}$

Como se pode perceber do texto legal, o legislador estabeleceu claramente a vinculação dos órgãos da administração da companhia aos termos do acordo. Criou a chamada autotulela, permitindo e obrigando o administrador da companhia, que esteja presidindo os trabalhos de uma assembleia geral ou reunião de órgãos colegiados da administração, a tomar ciência do acordo e desconsiderar os votos a ele infringentes ${ }^{166}$.

Além disso, ainda permitiu que os prejudicados, pelo não comparecimento ou abstenção de voto, tenham o direito de votar com as ações pertencentes ao acionista

necessidade de fazê-lo, consoante já anotado, por estar a situação prevista no art. 116, caput, e reiterada no $\S 2^{\circ}$ do art. 118. O fato é que a redação original do art. 118 , caput, não necessitava de emendas porque as regras dos arts. 115 e 117 delimitam, de forma adequada e suficiente, deveres, direitos e responsabilidades de controle exercido com base em acordo de acionistas." (SZTAJN, Rachel. Acordo de Acionistas. In SADDI, Jairo (Org.). Fusões e Aquisições: Aspectos Jurídicos e Econômicos. São Paulo: IOB, 2002., p. 276)

164 "Se deixar a companhia de declarar, no caso de votos contrários prevalecentes, suspensão da deliberação respectiva, deverão os convenentes propor, contra ela, a anulação dessa mesma deliberação, por manifesta ineficácia dos votos dados com inobservância do ajuste, sem embargo de responsabilidade contra os seus administradores, por violação dos seus deveres legais." (LEÃES, Luiz Gastão de Barros. Efeitos sobre terceiros dos acordos de acionistas. In Pareceres. São Paulo: Singular, 2004, p. 129)

165، (...) deve-se mencionar interessante crítica trazida à tona por Carlos Augusto Junqueira de Siqueira que identificou, na redação do $\S 9^{\circ}$, dificuldade em precisar a quem seriam conferidos poderes de mandatário em caso de, na ausência ou abstenção de pactuante, mais de um dos contratantes presentes à assembleia sentir-se prejudicado, não havendo, porém, entre estes, consenso com relação à forma de proferir o voto do ausente. (...) a meu ver, em caso de mais de um acionista sentir-se prejudicado, nenhum voto do ausente deveria ser computado, como se o ausente estivesse em discordância do acordo de acionistas, nos termos do $\$ 8^{\circ}$ do artigo 118." (SADDI, Jairo. Vinculação do voto dos administradores indicados pelo acordo de voto. In Estudos em Homenagem a Modesto Carvalhosa. São Paulo: Saraiva, 2012, pp. 666-667)

${ }^{166}$ Sobre os $\S \S 8^{\circ}$ e $9^{\circ}$ : “(...) surge uma responsabilidade eventual de indenização por perdas e danos contra o presidente do conclave que for omisso no cumprimento do dever em causa." (VERÇOSA, Haroldo Malheiros Duclerc. Curso de direito comercial. v. 3. 2a ed. São Paulo: Malheiros, 2011, p. 316) 
ausente ou omisso e, no caso de membro do conselho de administração, pelo conselheiro eleito com os votos da parte prejudicada ${ }^{167}$.

A inclusão de tais parágrafos representou, acima de tudo, uma tentativa de elevar a coerbilidade interna do acordo e evitar a necessidade de acionar o Poder Judiciário para sanar seu descumprimento ${ }^{168}$.

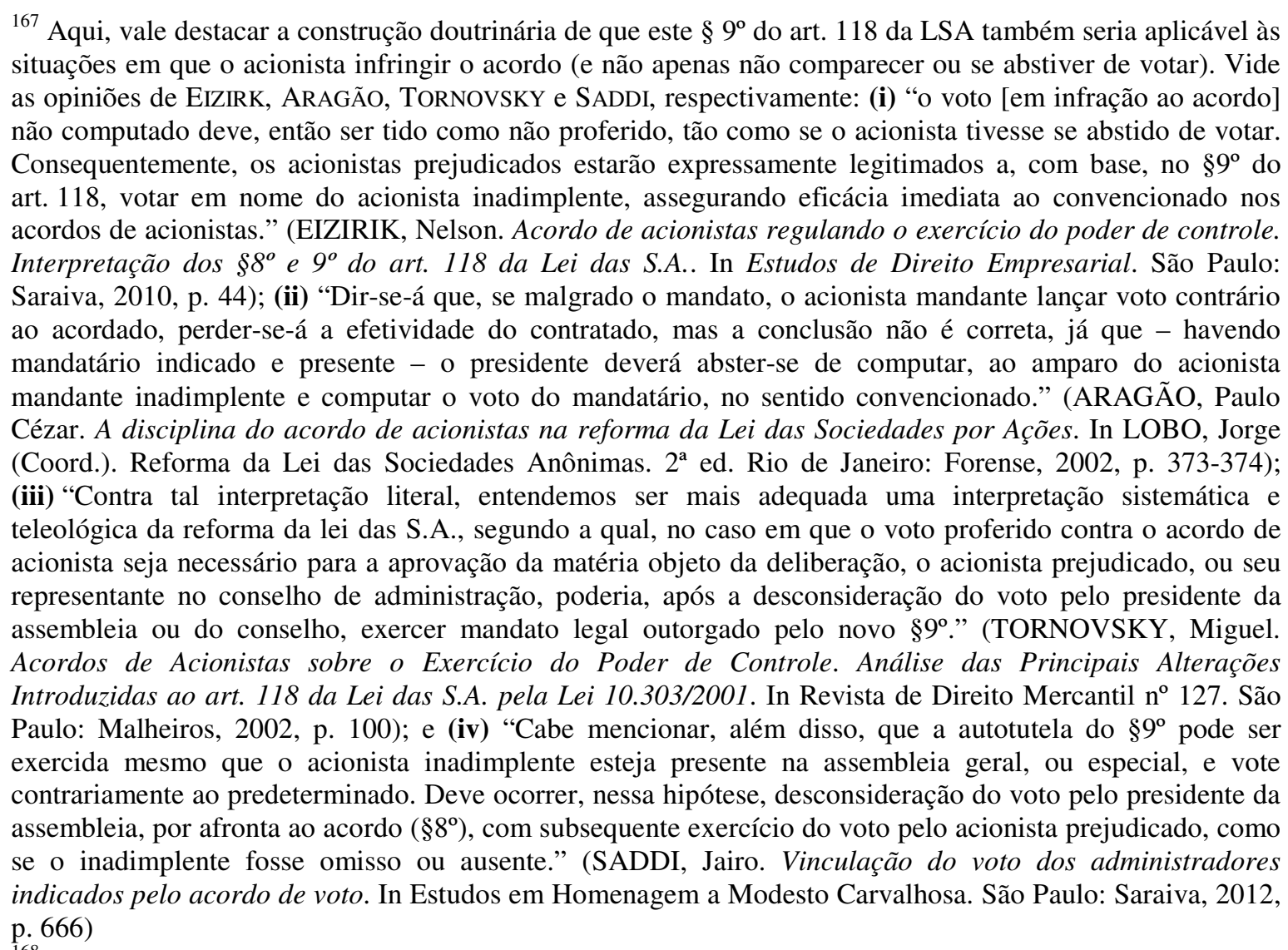

${ }^{168}$ Destacamos o embate doutrinário à época da promulgação da lei 10.303 , de 2001, que inseriu o $\S 9^{\circ}$ ao art. 118 da LSA. Para alguns juristas, a denominada autotutela interna seria insconstitucional por infringir o princípio da inafastabilidade da tutela jurisdicional. A nosso ver, essa questão já foi apaziguada e há consenso no sentido da constitucionalidade de tal parágrafo. Restou a falta de consenso ideológico sobre o assunto. A seguir, apontamos algumas citações acerca do mencionado embate sobre a constitucionalidade do $\S 9^{\circ}$ : (i) De um lado, EIZIRIK e SADDI, respectivamente, defensores da constitucionalidade: (a) "A regra do $\S 9^{\circ}$ do art. 118 da Lei das S.A. introduziu uma hipótese excepcional de autotutela legítima em nosso ordenamento jurídico. (...) Note-se que a regra estabelecida (...) não acarreta qualquer lesão ao princípio da inafastabilidade da tutela jurisdicional (art. $5^{\circ}$, inciso XXXV, da Constituição Federal)." (EIZIRIK, Nelson. Acordo de acionistas regulando o exercício do poder de controle. Interpretação dos $\$ 8^{\circ}$ e $9^{\circ}$ do art. 118 da Lei das S.A.. In Estudos de Direito Empresarial. São Paulo: Saraiva, 2010, p. 41); (b) “(...) Não há qualquer violação à norma constitucional, notadamente ao princípio da inafastabilidade da tutela jurisdicional prevista no art. $5^{\circ}$, XXXV, da CF, uma vez que as partes que se entenderem prejudicadas sempre encontram a via judicial aberta para a resolução definitiva da querela." (SADDI, Jairo. Vinculação do voto dos administradores indicados pelo acordo de voto. In Estudos em Homenagem a Modesto Carvalhosa. São Paulo: Saraiva, 2012, pp. 665); e (ii) De outro lado, BERTOLDI, favorável à inconstitucionalidade: "o $\S 9^{\circ}$ "fere frontalmente o primado do monopólio da jurisdição por parte do Poder Judiciário, admitindo juízo de exceção em colidência com o estatuído no art $5^{\circ}$ da Constituição Federal: inciso LIII - ninguém será processado nem sentenciado senão pela autoridade competente." (BERTOLDI, Marcelo M. In Jorge Lobo (Coord.). Reforma da Lei das Sociedades Anônimas - Inovações e Questões Controvertidas da Lei 10.303, de 31.10.2001, p. 94 e ss., apud, 
Sobre a vinculação dos membros da administração, trataremos desse ponto, mais especificamente, no Capítulo VI em diante. Antecipamos apenas que, embora ideologicamente controverso, a grande maioria da doutrina reconhece a indisputabilidade da força vinculativa do acordo à administração ${ }^{169}$. Segundo essa maioria de pensadores, tais parágrafos $\left(8^{\circ}\right.$ e $\left.9^{\circ}\right)$ tornaram os acordos mais fiéis à realidade de estrutura de capital concentrada brasileira $^{170}$.

Até hoje, inexiste consenso sobre a compatibilidade de tais alterações com o regime de governança da LSA (eminentemente os arts. 139, 142 e 154 a serem analisados no próximo capítulo).

Além da potencial incompatibilidade, diversos autores defensores das boas práticas de governança corporativa refutam completamente a intenção do legislador e a entendem como divergente do modelo utilizado por outras legislações estrangeiras ${ }^{171}$.

\subsubsection{Acordo de minoria}

LUCENA, José Waldecy. Das sociedades anônimas - comentários à lei (arts. $1^{\circ}$ a 120). v. 1. Rio de Janeiro: Renovar, 2009, p. 1.155)

169 "De modo geral, o poder de controle é exercido primeiro nos órgãos da administração, depois na assembleia geral (...). Dessa forma, seria inócuo o acordo que disciplinasse o poder de controle sem vincular a atuação dos administradores eleitos pelos integrantes do bloco de controle." (EIZIRIK, Nelson. A Lei das S.A. Comentada. Volume I - Arts. 1 a 120. São Paulo: Quartier Latin, 2011, p. 728)

${ }^{170}$ Vide as opiniões de CARVALHOSA e CALIXO SALOMÃo a esse respeito, respectivamente: (i) “(...) por força do $\$ 8^{\circ} \mathrm{m}$ i acordo oponível à sociedade passa a vincular não apenas os acionistas em assembleia geral ou especial, mas também os administradores indicados pelos acionistas, no que respeita às deliberações do órgão de que participem. Fica, assim, desde logo, evidente que os acordos de acionistas vinculam, ex vi desse $\S 8^{\circ}$, não apenas os membros do Conselho de Administração eleitos pela convenção de voto, mas também os diretores na mesma situação, nas reuniões desse órgão, quando não tiver a sociedade Conselho de Administração." (CARVALHOSA, Modesto. Comentários à lei das sociedades anônimas. v. 3. $5^{\mathrm{a}}$ ed. São Paulo: Saraiva, 2011, p. 6); e (ii) "em matéria de acordo de acionistas, a reforma societária de 2001 trouxe relevantes mudanças que ajudam a dar mais coerência às regras sobre a matéria. (...) os $\$ \S 8^{\circ}, 9^{\circ}, 10$ e 11 , procuraram inserir de forma bastante incisiva, o acordo de acionistas na realidade societária" (SALOMÃO FILHO, Calixto. O novo direito societário. $3^{\mathrm{a}}$ ed., São Paulo: Malheiros, 2006, p. 138)

${ }^{171}$ Neste sentido (entre outros autores identificados no Capítulo VI em diante): (i) CAMARGO, João Laudo; BOCATER, Maria Isabel do Prado. Conselho de Administração: seu Fucionamento e Participação de Membros Indicados por Acionistas Minoritários e Preferencialistas. In LOBO, Jorge (Coord.). Reforma da Lei das Sociedades Anônimas. $2^{\mathrm{a}}$ ed. Rio de Janeiro: Forense, 2002. pp. 385-422; (ii) SALLES DE TOLEDO, Paulo F. C. Modificações Introduzidas na Lei das Sociedades por Ações, quanto à Disciplina da Administração das Companhias. In LOBO, Jorge (Coord.). Reforma da Lei das Sociedades Anônimas. $2^{\mathrm{a}}$ ed. Rio de Janeiro: Forense, 2002. pp. 423-454; e (iii) SZTAJN, Rachel. Acordo de Acionistas. In SADDI, Jairo (Org.). Fusões e Aquisições: Aspectos Jurídicos e Econômicos. São Paulo: IOB, 2002. pp. 273-294. 
Ainda que não representem o principal escopo deste trabalho, destacamos também o papel do acordo de minoria, utilizado para organizar o poder dos acionistas minoritários e, assim, contrabalançar o poder de controle.

Por meio de tais acordos, os minoritários podem ter condições, por exemplo, atingir percentuais de participação credenciadores de uma eleição em separado de membros para o conselho de administração (i.e., preferencialistas sem direito a voto representando $10 \%$ do capital da companhia, ou ordinaristas representando $15 \%$, vide art. 140, § $4^{\circ}$, da LSA), ou adoção do voto múltiplo (art. 141, da LSA) ${ }^{172}$.

Aqui, tocamos em um ponto controverso, que trata da possibilidade de aplicação dos $\S \S 8^{\circ}$ e $9^{\circ}$ do art. 118 da LSA aos acordos de voto minoritário. Em outras palavras, se estariam os administradores eleitos pelos minoritários vinculados aos acordos de minoria e, consequentemente, às instruções por estes fornecidas.

Interessante notar a opinião de CARvalhosa a esse respeito. Para o jurista, tais parágrafos são destinados apenas e tão somente aos acordos de controle, conforme segue:

A tais acordos [de voto dos minoritários] não se aplica o disposto nos $\S \S 8^{\circ}$ e $9^{\circ}$ do art. 118 da lei societária, no tocante aos administradores em minoria por eles eleitos. Isto porque (...) são instrumentos do exercício harmônico e uniforme do poder de controle comum que, presume a lei, visa ao cumprimento e à implementação do interesse social, como reiterado. ${ }^{173}$

Essa interpretação tem por base, portanto, a presunção de que os controladores estariam atuando segundo o melhor interesse da companhia. Nesse sentido, deixar a administração de dar seguimento a uma instrução emanada do controlador representaria uma atitude contrária ao interesse da companhia e, portanto, censurável. Nos casos em que a conduta do controlador distanciar-se do interesse social, tal acionista estaria incorrendo em abuso de poder de controle, passível de responsabilização e indenização.

\footnotetext{
${ }^{172}$ Vide a lição de ElZIRIK: "Pode também o acordo de voto estabelecer que os seus membros votarão em conjunto para eleger uma chapa de membros do conselho de administração, ou que cada parte terá o direito de eleger determinados administradores, de sorte que todos os votos do bloco serão direcionados naquele sentido." (EIZIRIK, Nelson. A Lei das S.A. Comentada. Volume I - Arts. 1 a 120. São Paulo: Quartier Latin, 2011, p. 707)

${ }^{173}$ CARVALHOSA, Modesto. Acordo de Acionistas. São Paulo: Saraiva, 2011, p. 261.
} 
Respeitamos a posição do jurista, mas, sinceramente, não entendemos que exista previsão legal justificadora de um tratamento diferenciado entre acordos de controle e de acordos de minoria, no que diz respeito à incidência dos $\S \S 8^{\circ}$ e $9^{\circ}$ do art. 118 da $\operatorname{LSA}^{174}$.

O texto do $\S 8^{\circ}$ dispõe que não serão computados os votos “(...) com infração de acordo de acionistas devidamente arquivado". Isto é, não há especificação do tipo de acordo, se de controle, de exercício de direito de voto, de compra e venda de ações ou de preferência para adquiri-las.

Como nos ensina MAXIMILIANO ${ }^{175}$, regras restritivas de direitos (como seria a eventual não incidência dos $\S \S 8^{\circ}$ e $9^{\circ}$ aos acordos de minoria) não podem ter interpretação ampliativa.

Assim, independentemente de nossa posição ideológica acerca da vinculação de administradores a acordos de acionistas, manifestada ao final deste trabalho, entendemos serem aplicáveis os $\S \S 8^{\circ}$ e $9^{\circ}$ também aos acordos de minoria devidamente arquivados na sede da companhia.

\subsubsection{Natureza jurídica}

Aprofundando um pouco mais o estudo do principal instrumento de organização do poder do acionista, resta-nos, ainda, comentar acerca de sua natureza jurídica. Exercício este que é essencial ao devido entendimento de um instituto e, principalmente, dos meios e soluções disponíveis para interpretar e solucionar seus problemas.

Podemos dizer que a maioria da doutrina hoje, com a qual concordamos, classifica o acordo de acionistas como um contrato plurilateral parassocial ${ }^{176}$ e, portanto, sujeito

\footnotetext{
${ }^{174}$ Nestse sentido, LOBO: “A aplicação dos $\$ \S 8^{\circ}$ e $9^{\circ}$ do artigo 118 em relação a acordos de acionistas celebrados por minoritários, ou entre controladores e minoritários, tem fundamento, além do texto expresso da lei, na obrigação de a companhia, por seus órgãos, observar os acordos de acionistas arquivados, bem como no princípio da boa-fé na execução dos contratos." (LOBO, Carlos Augusto da Silveira. BULHÕES PEDREIRA, José Luiz; LAMY FILHO, Alfredo (Coord.). In Direito das Companhias. v. I. Rio de Janeiro: Forense, 2010, p. 487)

${ }^{175}$ Em Hermenêutica e Aplicação do Direito. $8^{\mathrm{a}}$ ed. Rio de Janeiro: Forense, 2011, pp. 237-245.

${ }^{176}$ Essa ambém parecer ser a maneira pela qual a jurisprudência tem classificado a natureza do acordo de acionistas: "Apelação cível. Execução de obrigação de não fazer. Acordo de Acionistas. Natureza jurídica e eficácia. Tendo o acordo de acionistas natureza de negócio jurídico plurilateral, submete-se às regras gerais
} 
(i) às normas gerais de existência, validade e eficácia aplicáveis a todos os contratos e (ii) acessório ao estatuto social. Assim posicionaram-se COMPARATO ${ }^{177}$, EIZIRIK $^{178}$ e BARBI FILHO $^{179} 180$.

Alguns autores chegam a analisar e diferenciar a natureza jurídica do acordo de acionistas conforme seu objeto. Nesse sentido, CARVALHOSA ${ }^{181}$ entende que o acordo de

de teoria dos contratos, tornando-se obrigatórias as condutas ali disciplinadas. Seu descumprimento importa na anulação das decisões tomadas ao seu arrepio (...) A doutrina pátria (...) admite que qualquer dos acionistas ingresse em juízo para pedir a dissolução da avença, por quebra da affectio societatis, o que decorre da natureza parassocial do acordo de acionistas." (TJRJ, 10 a Cam., AC 14.620/05, Rel. Des. Sylvio Capanema de Souza, j. 18.10.2005)

${ }^{177}$ Vide COMPARATO, Fábio Konder. Acordo de acionistas e interpretação do art. 118 da Lei das S.A. RT, Ano 68 - Setembro 1979, volume 527, p. 33, apud, SALLES, Denise Chachamovitz Leão de. Acordo de Acionistas: um Panorama Evolutivo. In CASTRO, Rodrigo R. Monteiro de; ARAGÃO, Leandro Santos. Sociedade Anônima: 30 anos da Lei 6.404/76. São Paulo: Quartier Latin, 2007, p. 488.

178 "O acordo de acionistas possui natureza acessória em relação ao contrato social, visto que (...) sua eficácia depende da existência da pessoa jurídica, em cuja esfera dar-se-á a sua execução. Note-se que, apesar de regulados pela lei societária, os acordos de acionistas caracterizam-se como contratos submetidos às normas comuns de validade de todos os negócios jurídicos de direito privado." (destaques nossos) (EIZIRIK, Nelson. Acordo de acionistas regulando o exercício do poder de controle. Interpretação dos $\S^{\circ}$ e $9^{\circ}$ do art. 118 da Lei das S.A.. In Estudos de Direito Empresarial. São Paulo: Saraiva, 2010, p. 32)

179 BARBI FILHO também classifica o acordo de acionistas como um contrato parassocial. Acrescenta, porém, que se trata de um contrato preliminar, podendo ser plurilateral ou unilateral em relação a seus efeitos. (BARBI FILHO, Celso. Acordo de Acionistas. Belo Horizonte: Del Rey, 1993, p. 61)

${ }^{180}$ Destacamos, a seguir, as posições divergentes de VERÇOSA e SZTAJN, respectivamente, acerca do assunto em referência, bem como a contribuição de LUCENA sobre outros entendimentos doutrinários: (i) "É importante verificar a natureza jurídica do instituto como não contratual para o fim da aplicação das regras adequadas quando do surgimento de questões jurídicas àquele relacionadas. Embora a compra e venda de ações prevista em acordo seja um contrato (pois está claramente presente a patrimonialidade da relação jurídica entre as partes), o acordo parassocial de acionistas no qual o objeto seja o exercício do direito de voto não é um contrato e não está sujeito às normas específicas deste instituto. (...) Trata-se de acordo ou convenção, uma modalidade de negócio jurídico, não correspondente à figura do contrato." (destaques nossos) (VERÇOSA, Haroldo Malheiros Duclerc. Curso de direito comercial. v. 3. $2^{\mathrm{a}}$ ed. São Paulo: Malheiros, 2011, pp. 306 e 309); (ii) "Conclusão preliminar é que, adotada a definição de contrato do Direito italiano, os acordos de acionistas não preenchem um dos requisitos fundamentais, a patrimonialidade do negócio, para serem qualificados como contratos. (...) Com base nas alternativas da lei $\mathrm{n}^{\circ}$. 6.404/1976, parece-me que não se trata de contrato e sim de outro tipo de negócio plurilateral." (SZTAJN, Rachel. Acordo de Acionistas. In SADDI, Jairo (Org.). Fusões e Aquisições: Aspectos Jurídicos e Econômicos. São Paulo: IOB, 2002., p. 280); e (iii) "Há os que entendem tratar-se de sociedade (Garrigues-Uría, Comentarios a la Ley de Sociedades Anónimas, Madrid: Aguirre, 1976, cit., v. 1, p. 665). (...) Para outros, o acordo de acionistas não alcança as características de um contrato, sendo ato coletivo e complexo (Weiller apud Garrigues-Uría, Comentarios, cit., v. 1, p. 666). Ainda, outra escola atribui à avença natureza sui generis, na medida em que seria uma associação com elementos atípicos muito especiais, porém próximos daqueles da sociedade (Pedrol, La anônima actual y la sindication de acciones, Madrid: Revista de Derecho Privado, 1969, cit., p. 39 e s.) (...)". (LUCENA, Waldecy. Das Sociedades Anônimas - Comentários à Lei. v. 1. Rio de Janeiro: Renovar, 2009, p. 1.132 e ss.)

181 "Em razão do vínculo institucional expresso na lei societária (art. 118), o acordo de controle, no Direito Societário brasileiro, não pode ser considerado como um contrato parassocial, que é categoria reservada apenas ao acordo de voto, próprio dos minoritários. Também não é parassocial o acordo de bloqueio, por se tratar de contrato bilateral ou unilateral (opção), de caráter patrimonial típico, que não se vincula à consecução do interesse social. Daí não ser parassocial o acordo de bloqueio, pois não se alinha, subsidiária ou acessoriamente, ao interesse social, como ocorre com o acordo de voto dos minoritários. (...) os acordos de controle e, também, os acordos de voto dos minoritários têm caráter plurilateral, em face da confluência de sufrágios para a realização de determinado fim comum - o exercício do controle ou o exercício dos direitos 
controle (ou de comando) e o acordo de minoria possuem natureza de contrato plurilateral $^{182}$, sendo este (de minoria) parassocial, mas não o primeiro (de controle). Em sua opinião, o acordo de comando representa um próprio órgão societário, não havendo sentido, portanto, dizer que ele deva conformar-se com a estrutura societária da companhia, já que acaba justamente por determinar o seu funcionamento.

O jurista também é da opinião de que o acordo (ou cláusulas) de bloqueio (i.e., compra e venda de ações ou preferência para adquiri-las) possui natureza de contrato bilateral ou unilateral e não parassocial, uma vez que não se vincula à consecução do interesse social.

De nossa parte, entendemos que, independentemente do tipo de acordo de acionistas, este sempre revestirá a natureza contratual (plurilateral no caso dos acordos de comando e de minoria, e bilateral nos acordos de bloqueio) e parassocial.

É fato que a comunhão de controle tem o poder de determinar o funcionamento da estrutura societária e, portanto, modificar o conteúdo do estatuto social, por exemplo. Mas, independentemente disso, é o estatuto social o documento constitutivo da companhia, aquele que determina sua lei interna e, por natureza, é destinado a uma gama muito maior de terceiros do que o acordo de acionistas. E é justamente sob o enfoque dos terceiros que se relacionam com a companhia que o acordo de acionistas terá sempre natureza acessória em relação ao estatuto social.

\subsubsection{Notas sobre Direito Comparado}

De forma geral, é possível afirmar que o acordo de acionistas foi recepcionado e é utilizado nos principais sistemas de direito societário no mundo, seja nos países de estruturas de capital concentrado ou disperso.

dos minoritários, respectivamente." (CARVALHOSA, Modesto. Acordo de Acionistas. São Paulo: Saraiva, 2011, pp. 41-42 e 76)

182 "Ressalta-se, ainda, a não aplicação do princípio da exceptio non adimpleti contractus, na medida em que cada pactuante assume obrigações perante todos os demais, não podendo invocar o descumprimento das obrigações de um, para eximir-se de cumprir a prestação prometida." (CARVALHOSA, Modesto. Acordo de Acionistas. São Paulo: Saraiva, 2011, p. 154) 
Nos Estados Unidos ${ }^{183}$, por exemplo, os acordos costumam tratar de regras de composição do conselho de administração e de governança corporativa, além do fato de o direito de voto ser regulado pelo direito das obrigações e não societário. Com isso, a convenção de voto restringe-se ao âmbito dos acionistas, não obrigando a companhia em $\mathrm{si}^{184}$.

Nos países latinos da Europa ${ }^{185}$, exceto pela vinculação de administradores a $\operatorname{acordos}^{186}$, os acordos de voto são admitidos e sujeitos a regras parecidas com as nossas, eminentemente, a impossibilidade de tais acordos contrariarem a lei, o estatuto social e o interesse da sociedade.

A França ${ }^{187}$ ainda não regula as convenções de voto em sua legislação e a Itália o fez somente a partir de $1998^{188}$. A lei germânica ${ }^{189}$ também recepcionou o acordo de acionistas e a ele dedicou tratamento também consistente com a prática empresarial global, tendo chegado a prever execução específica das obrigações do acordo e a impossibilidade de os acionistas votarem conforme determinação dos administradores ou de terceiros.

\subsection{Soberania da assembleia geral de acionistas}

Conforme aludido anteriormente, o correto entendimento do problema objeto deste trabalho (vinculação do poder da administração ao poder do acionista) exige um estudo específico de cada fonte de poder para, a partir disso, não só determinar a possibilidade ou não de vinculação, mas principalmente vislumbrar a existência de eventuais limites a tal situação.

183 "Tanto a General Corporation Law of the State of Delaware (DGCL) quanto a New York Business Corporation Law (NYBCL) reconhecem a validade de um acordo entre dois ou mais acionistas, se ele for escrito e assinado por todos, e estabelecer o modo como serão exercidos os direitos políticos (DGCL tit. 8, §218(iii) (2001); NYBCL § 620(i) (McKinney 2003)." (CARVALHOSA, Modesto. Acordo de Acionistas. São Paulo: Saraiva, 2011, p. 232)

${ }^{184}$ Vide LOBO, Carlos Augusto da Silveira. BULHÕES PEDREIRA, José Luiz; LAMY FILHO, Alfredo (Coord.). In Direito das Companhias. v. I. Rio de Janeiro: Forense, 2010, p. 448.

${ }^{185}$ Vide LOBO, Carlos Augusto da Silveira. BULHÕES PEDREIRA, José Luiz; LAMY FILHO, Alfredo (Coord.). In Direito das Companhias. v. I. Rio de Janeiro: Forense, 2010, p. 449.

${ }^{186}$ Trata-se de previsão tipicamente brasileira não encontrada em outras legislações, exceto conforme disposto no Capítulo VIII deste trabalho.

${ }^{187}$ Vide LOBO, Carlos Augusto da Silveira. BULHÕES PEDREIRA, José Luiz; LAMY FILHO, Alfredo (Coord.). In Direito das Companhias. v. I. Rio de Janeiro: Forense, 2010, p. 451.

${ }_{188}$ Vide LOBO, Carlos Augusto da Silveira. BULHÕES PEDREIRA, José Luiz; LAMY FILHO, Alfredo (Coord.). In Direito das Companhias. v. I. Rio de Janeiro: Forense, 2010, pp. 451-452.

${ }^{189}$ Vide LOBO, Carlos Augusto da Silveira. BULHÕES PEDREIRA, José Luiz; LAMY FILHO, Alfredo (Coord.). In Direito das Companhias. v. I. Rio de Janeiro: Forense, 2010, p. 453. 
Analisado o principal instrumento de organização do poder do acoinista (o acordo de acionistas) e suas disposições sobre vinculação do poder da administração, ainda no âmbito daquele poder, analisaremos agora a soberania da assembleia geral para, ao final, sabermos se este argumento (da soberania) também poderia ser utilizado para justificar a vinculação de administradores.

A fonte do estudo acerca da soberania assemblear está no art. 121 da LSA, o qual determina que "a assembléia-geral (...) tem poderes para decidir todos os negócios relativos ao objeto da companhia e tomar as resoluções que julgar convenientes à sua defesa e desenvolvimento".

Seria, então, a assembleia soberana o suficiente para deliberar sobre todas as matérias do art. 142? Alternativa e mais especificamente, seria admissível a realização de uma reunião prévia (afinal, equivalente a uma assembleia) de acionistas para vincular o voto de conselheiros em uma reunião de tal órgão tratando de quaisquer matérias, inclusive as privativas?

As respostas a tais questionamentos serão tratadas em nossa conclusão, no Capítulo $\mathrm{X}$. Por ora, analisaremos como a doutrina tem interpretado a soberania da assembleia geral.

Ao longo da evolução da sociedade anônima, a assembleia geral foi vitimada pelo absenteísmo dos acionistas e transformou-se em órgão apenas formalmente soberano.

Não obstante, em sistemas concentrados como o brasileiro, discordamos da opinião corrente de que "as atribuições dos administradores tornam-se incomparavelmente maiores do que a competência anteriormente ostentada pela assembleia geral" ${ }^{\text {190 }}$. Pela análise que fizemos acima sobre os acordos de acionistas, não foi a administração que recebeu as atribuições antes conferidas pela assembleia geral, mas sim as reuniões prévias de acionistas.

${ }^{190}$ CARVAlHOSA, Modesto. Comentários à lei das sociedades anônimas. v. 2. $5^{\mathrm{a}}$ ed. São Paulo: Saraiva, 2011, p. 764. 
Essa observação é importante, pois ao invés de exergarmos as disposições sobre assembleia geral (principalmente o art. 121 da LSA) como meramente teóricas, devemos, na verdade, aplicá-las a esse novo órgão contratual que assumiu suas funções.

Assim, entendemos que interpretar a extensão do art. 121 da LSA representa um exercício extremamente valioso do ponto de vista prático e não teórico, como sugerem os pensadores. Isso porque se a reunião prévia substituiu a assembleia geral, por analogia, devem àquela ser aplicados os mesmos princípios e regras desta. Trata-se, acima de tudo, de analisar o instituto e aplicar a norma pela sua função exercida.

Dito isso, em tempos atuais, a assembleia não mais é revestida da soberania de antigamente $^{191}$. Embora ainda existam defensores de sua supremacia absoluta ${ }^{192}$, o entendimento majoritário é o de que sua soberania é relativa e funcional ${ }^{193}$.

191 "A lei vigente de 1976, no capítulo das atribuições e poderes da assembleia geral, abandona as características de órgão deliberativo soberano da companhia, que lhe conferia o antigo diploma (...)" (CARVAlHOSA, Modesto. Comentários à lei das sociedades anônimas. v. 2. $5^{\mathrm{a}}$ ed. São Paulo: Saraiva, 2011, p. 756).

192 (i) “(...) Em nosso entendimento, por força do artigo 121, a Assembleia Geral, fonte dos poderes do acionista controlador, tem poderes para deliberar sobre todos os negócios relativos ao objeto da companhia, inclusive aqueles de competência do Conselho de Administração (...)" (LOBO, Carlos Augusto da Silveira. BULHÕES PEDREIRA, José Luiz; LAMY FILHO, Alfredo (Coord.). In Direito das Companhias. v. I , p. 487-488); e (ii) Essa parece ter sido também a interpretação conferida no seguinte julgado: "Em caso em que o estatuto da companhia dava competência aos administradores para deliberar sobre aumento de capital através da emissão de ações até o limite de 30\% do próprio capital social, o Tribunal de Justiça de São Paulo decidiu: 'Mas, evidentemente, tal competência não exclui a competência da assembleia geral, como órgão soberano da sociedade, de deliberar sobre o mesmo assunto. Em verdade, a competência do Conselho Diretor configura-se em faculdade de atuar, que não pode conflitar com a competência do órgão máximo de deliberação da sociedade, a assembleia geral, esta com poderes para ratificar ou não todos os atos que interessam à sociedade'.” (TJ-SP, Apelação Cível n. 119.219-1, Rel. Desembargador Godofredo Mauro).

193 “a subordinação hierárquica dos administradores à assembleia geral deve ser compreendida em seus estritos termos. Nenhum dos órgãos da companhia recebe os seus poderes por delegação de outro; recebe-os diretamente da lei (ou do contrato social, para parte da doutrina) e deles não pode ser espoliado. A administração não é mandatária da assembleia geral e, de acordo com a precisa lição de Fábio Konder Comparato, 'a intervenção de um órgão no outro não se faz a nível de competência, mas de preenchimento de cargos’ (In: Novos ensaios..., cit., p. 97). A relação estabelecida entre assembleia geral e administração é, antes de tudo, de controle e orientação, e não propriamente de supremacia. Até mesmo o poder atribuído pela lei acionária à assembleia geral para 'decidir todos os negócios relativos ao objeto da companhia e tomar as resoluções que julgar convenientes à sua defesa e desenvolvimento’ (LSA, art. 121) - previsão esta de todo platônica e idealista, quando se tem em vista a preponderância da vontade do acionista controlador, a quem cabe o efetivo poder de ditar os rumos da companhia (LSA, art. 116) - não é absoluto, pois, em tema de gestão de empresa, a competência da administração é privativa (LSA, art. 139), e os administradores, por isso, não são instrumentos passivos das decisões de outrem: não estão vinculados ao cumprimento de deliberações da assembleia geral diretamente relacionadas com matérias de gestão nem podem curvar-se a estipulações de acordos de acionistas usurpadoras de suas privativas competências. Na Lei das S.A., os poderes sociais encontram-se institucionalmente distribuídos entre os vários órgãos, e todo órgão é soberano no âmbito de sua própria esfera privativa de competência." (VON ADAMEK, Marcelo Vieira. Responsabilidade dos Administradores de S.A. e as Ações Correlatas. São Paulo: Saraiva, 2009. pp. 137138) 
Em outras palavras, embora hierarquicamente superior aos demais órgãos societários ${ }^{194}$, a assembleia somente é capaz de eleger membros de outros órgãos e instruir sua atuação ${ }^{195}$, mas não por esse motivo substituí-lo em suas funções ${ }^{196}$. Essa interpretação resulta da teoria organicista (estudada no Capítulo II acima), adotada pela LSA ${ }^{197}$. A inteligência do art. 139 é emblemática nesse sentido.

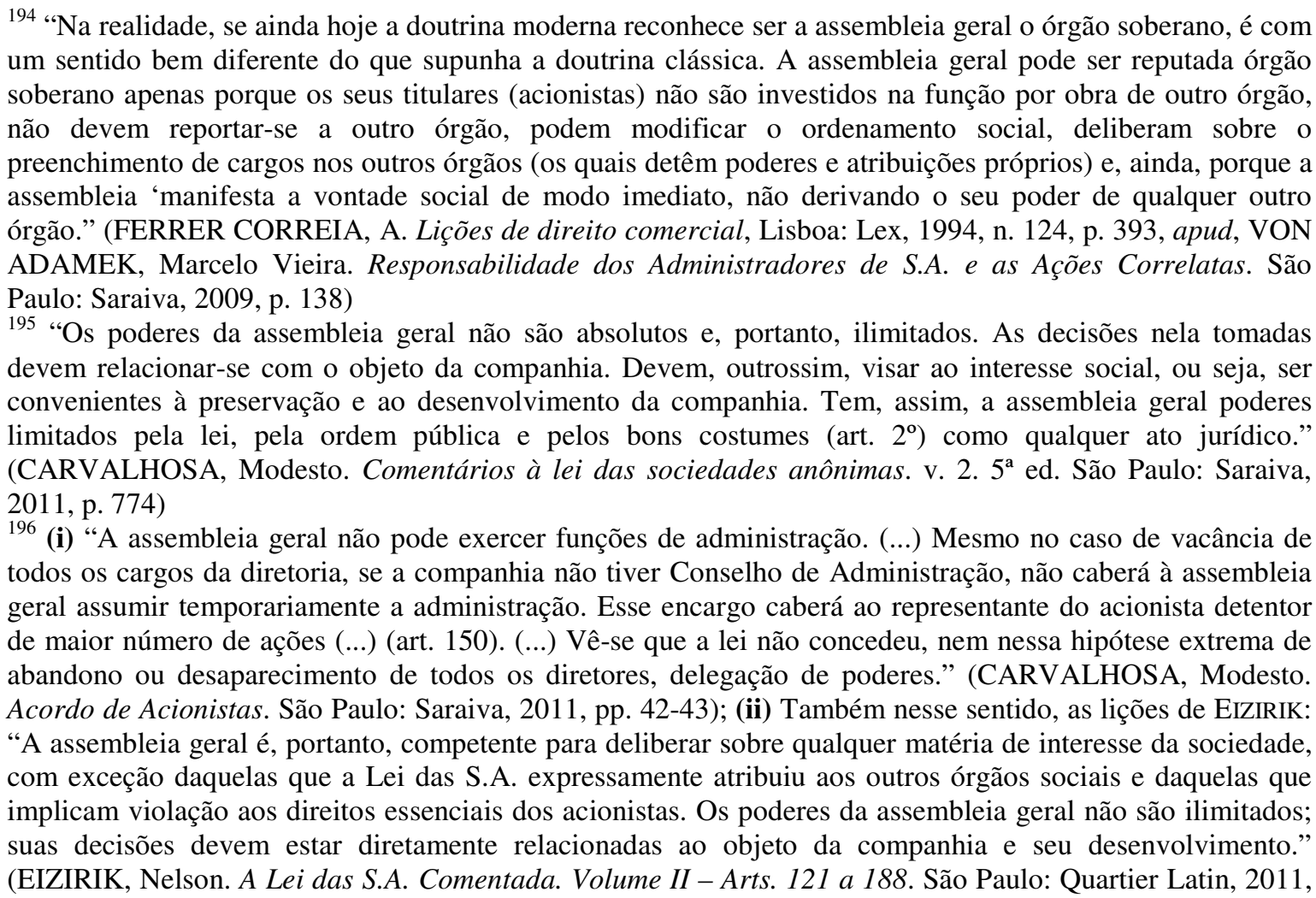
p. 24)

${ }^{197}$ CARVAlhos contribui com as seguintes lições de Direito Comparado: (i) "A lei societária alemã de 1965, em seu art. 119, restringe muito os direitos da assembleia geral, determinando que esta deliberará somente nos casos estabelecidos expressamente em lei, ou no estatuto, não podendo tomar resoluções sobre matérias relativas à gestão social, salvo se a pedido da própria diretoria (Vorstand). Não se prevê seque que tal pedido possa ser feito pelo Conselho de Administração." (CARVALHOSA, Modesto. Comentários à lei das sociedades anônimas. v. 2. $5^{\text {a }}$ ed. São Paulo: Saraiva, 2011, p. 765); (ii) “A lei francesa de 1966 limitou o papel da assembleia geral e acentuou a sua subordinação ao Conselho Supervisor, que efetivamente detém todos os poderes necessários à administração e gestão social. Cabe ao Conselho de Supervisão eleger e também propor a destituição dos membros da diretoria. Além disso, a destituição dos diretores somente poderá ser deliberada pela assembleia geral por justa causa." (CARVALHOSA, Modesto. Comentários à lei das sociedades anônimas. v. 2. $5^{\mathrm{a}}$ ed. São Paulo: Saraiva, 2011, p. 765); (iii) "No direito norte-americano, muitas legislações estaduais reconhecem a desnecessidade da assembleia geral. Ademais, em regra, os acionistas não intervêm nos negócios ordinários da companhia. Assim, não deliberam sobre a distribuição de dividendos e não têm poderes para fiscalizar os administradores, limitando-se a sua competência em nomeálos e destituí-los." (CARVALHOSA, Modesto. Comentários à lei das sociedades anônimas. v. 2. $5^{\text {a }}$ ed. São Paulo: Saraiva, 2011, p. 766); e (iv) “Também a Sociedade Anônima Européia (...) estabelece os assuntos sobre os quais é tal órgão competente para deliberar. Dessa forma, com exceção dos assuntos enumerados sem dispositivo específico, todo o poder decisório da companhia passará às mãos dos órgãos da administração." (CARVALHOSA, Modesto. Comentários à lei das sociedades anônimas. v. 2. $5^{\mathrm{a}}$ ed. São Paulo: Saraiva, 2011, pp. 766-767) 
Dessa forma, a nosso ver, assim devemos interpretar a extensão do art. 121 da LSA (soberania relativa e funcional) e a tais limites deve se submeter a reunião prévia de acionistas que, em tempos modernos, tem assumido a função da assembleia geral de acionistas. 


\section{O PODER DA ADMINISTRAÇÃO EM FOCO}

Como dito acima, a possibilidade de a administração ser submetida ou vinculada aos acionistas exige um prévio conhecimento das especificidades de cada um desses poderes.

Se, de um lado, conforme verificado no Capítulo IV acima, os $\S \S 8^{\circ}$ e $9^{\circ}$ do art. 118 da LSA e, limitadamente, o princípio da soberania da assembleia geral atuam em favor da vinculação da administração, de outro, o dever fiduciário de proteção do interesse social atribuído aos administradores (art. 154 da LSA), o princípio da indelegabilidade de funções (concebido pelo art. 139 da LSA), o rol de matérias de competência privativa da administração (e.g., art. 142 da LSA), bem como as boas práticas de governança corporativa, sugerem uma interpretação diversa, podendo justificar desde a impossibilidade de vinculação até uma vinculação limitada ${ }^{198}$.

Assim, neste capítulo, analisaremos a segunda fonte de poder, a gerencial, e os elementos potencialmente contraditórios apontados acima.

A administração como uma fonte de poder $^{199}$ foi inicialmente vislumbrada a partir da clássica lição de BERLE e MEANS ${ }^{200}$, sobre a dissociação entre propriedade e poder.

\footnotetext{
198 "O legislador pátrio (...) corretamente optou, de um lado, por preservar a liberdade de atuação dos administradores, conferindo-lhes atribuições e poderes privativos e (consequentemente) indelegáveis (LSA, arts. $138, \S 1^{\circ}, 139$ e 144$)$, e, de outro lado, resolveu pautar o comportamento dos administradores por padrões de conduta gerais e abstratos, verdadeiras cláusulas-gerais a serem contrastadas com sua atuação específica em cada caso concreto (arts. 153 a 157), em clara aproximação à técnica legislativa da common Law (...). A responsabilidade civil, escusado dizê-lo, constitui importante elemento de regulação da conduta dos administradores, pois torna efetivos os seus vários deveres nos planos societários (...)" (VON ADAMEK, Marcelo Vieira. Responsabilidade dos Administradores de S.A. e as Ações Correlatas. São Paulo: Saraiva, 2009, p. 113)

199 “'A partir do fim do Século XIX, iniciou-se um processo de concentração nas economias industrializadas, que conduziu à formação de empresas de grande escala. (...) Depois do Shearman Act, de 1890, que proibiu as práticas monopolistas, a concentração prosseguiu mediante fusões, incorporações e holding companies. (...) $\mathrm{Na}$ década de 1960 verificou-se novo aumento do número de operações de fusão, incorporação e aquisição de controle (...), com a formação de conglomerados - companhias, ou grupos de companhias que produzem bens e serviços em diferentes setores da economia (...). Um dos efeitos do aumento de escala da companhia é a dispersão da propriedade das ações: quanto maior a dimensão da companhia, mais difícil é cada acionista manter sua porcentagem de participação nos aumentos de capital necessários ao financiamento da expansão da empresa (...); e a crescente pulverização das ações da grande companhia cria o fenômeno referido como separação entre o poder de controle e a propriedade das ações, cuja análise (...) foi formulada pela primeira vez por Berle; Means (...)" (BULHÕES PEDREIRA, José Luiz e LAMY FILHO, Alfredo. In Direito das Companhias. v. I. Rio de Janeiro: Forense, 2010, p. 784)

${ }^{200}$ BERLE, Adolf e MEANS, Gardiner. Modern Corporation and Private Property. $10^{\mathrm{a}}$ ed Londres: Transaction Pub, 2010.
} 
Atentos à realidade da estrutura proprietária das companhias norte-americanas ${ }^{201}$, os autores identificaram um fenômeno jurídico não muito comum, o da detenção da propriedade de um bem sem o correspondente poder ${ }^{202}$.

Essa percepção permitiu a correta identificação do agency problem, característico de estruturas dispersas, representado pelo conflito entre os detentores do capital e a administração da companhia ${ }^{203}$.

Nas estruturas concentradas, por sua vez, ainda que do ponto de vista prático a administração, em regra, não seja a fonte de poder prevalecente (exceto em situações não usuais de absenteísmo do acionista controlador), ela representa um intermediário fundamental e estratégico na (potencialmente conflituosa) relação entre controladores e minoritários.

O fato é que, independentemente das estruturas e conflitos apontados acima, o poder gerencial exerce papel fundamental na sociedade anônima (seja como fonte de poder prevalecente ou intermediário entre controlador e minoria ${ }^{204}$, daí a necessidade de um

201 “A macroempresa com a propriedade do capital pulverizada e o poder de controle exercido pelos administradores somente alcançou porcentagem apreciável do universo das companhias dos Estados Unidos e da Inglaterra. Nos países da Europa Continental são em menor número, mas a tendência das legislações, a partir da lei alemã de 1937, foi limitar a competência da assembleia geral e aumentar a autonomia dos administradores. (...)" (BULHÕES PEDREIRA, José Luiz e LAMY FILHO, Alfredo. In Direito das Companhias. v. I. Rio de Janeiro: Forense, 2010, p. 786)

202 "Nesse modelo de companhia, a oferta pública para aquisição do controle é o instrumento do mercado para mudar a administração da companhia que não maximiza o valor das ações (...)" (BULHÕES PEDREIRA, José Luiz e LAMY FILHO, Alfredo. In Direito das Companhias. v. I. Rio de Janeiro: Forense, 2010, pp. 786)

203 “'O excesso de poder detido pelos administradores, em vista de escândalos como os da Enron, WorldCom e de diversas companhias no curso da crise financeira iniciada em 2008, tem sido alvo de severas críticas (...). Essas críticas são no sentido de atribuir maior poder aos acionistas, por exemplo, mediante a eliminação dos staggered boards [regra de substituição escalonada dos membros do conselho de administração], assegurando-se a estes a possibilidade de substituição imediata do conjunto de administradores." (MUNHOZ, Eduardo Secchi. Quem deve comandar a companhia? Alocação do poder empresarial: sistema de freios $e$ contrapesos. In Estudos em Homenagem a Modesto Carvalhosa. São Paulo: Saraiva, 2012, p. 513).

204 “A primeira Lei a aumentar a autonomia dos administradores foi a alemã, de 1937 (...). O Código Civil italiano de 1942 seguiu o exemplo da Alemanha: segundo Galgano (1988, p. 219), a assembleia geral '...não pode deliberar validamente nas matérias que sejam expressamente atribuídas à sua competência. $\mathrm{O}$ elenco das matérias de sua competência é taxativo, não meramente exemplificativo (...). A competência da assembleia é, portanto, uma competência especial; ao contrário, a competência do órgão administrativo é geral: qualquer matéria que não seja expressamente atribuída à competência da assembleia (...) é matéria de competência dos administradores. A lei francesa de 1966 atribuiu ao Conselho de Administração os mais amplos poderes de agir em qualquer circunstância em nome da sociedade, tendo por únicos limites o objeto social e os poderes expressamente atribuídos por lei às assembleias de acionistas; e a lei holandesa de 1971 retirou da assembleia até a competência de eleger administradores; mas a reforma espanhola de 1951 manteve o princípio da supremacia da assembleia geral.” (BULHÕES PEDREIRA, José Luiz e LAMY FILHO, Alfredo. In Direito das Companhias. v. I. Rio de Janeiro: Forense, 2010, p. 787) 
entendimento claro de suas funções e deveres sob duas perspectivas, (i) do modelo atual, i.e., interpretação do que já existe em nossa legislação/autorregulação sobre o assunto; e (ii) modelo ideal, i.e., eventuais acréscimos ou revisões ao modelo existente.

\subsection{Deveres fiduciários da administração}

Ciente da importância do papel dos administradores ${ }^{205}$ na sociedade anônima e da dificuldade de prever comportamentos fechados para responsabilizá-los ${ }^{206}$, a LSA adotou o bem sucedido modelo norte-americano de padrões de conduta (standards) ${ }^{207}$, baseado em um regime de deveres fiduciários (fiduciary duties) ${ }^{208}$.

Tendo em vista a inevitável (e essencial) discricionaridade inerente à atividade desenvolvida pelos administradores, o regime dos deveres fiduciários ganha ainda mais relevo, pois determina os limites de sua atuação e um consequente meio de responsabilização ${ }^{209}$.

\footnotetext{
205 “(...) a norma somente se aplica aos administradores estatutários, assim entendidos aqueles eleitos pela assembleia geral ou pelo Conselho de Administração, não se estendendo aos executivos contratados ou aos procuradores da companhia. Isto é, ressalva feita à hipótese de conluio dentre estas pessoas e os administradores." (FRANCO, Vera Helena de Melo; SZTAJN, Rachel. Direito Empresarial II: sociedade anônima, mercado de valores mobiliários. $2^{a}$ ed. ver. atual. e ampl. São Paulo: Revista dos Tribunais, 2009, p. 182).

${ }^{206}$ Interessante o questionamento feito por CARVALHO DE MENDONÇA em contexto diverso sobre o regime da liberdade contratual de constituição de sociedades anônimas, mas completamente aplicável à dificuldade em comento de prever condutas dos administradores e o intento do regime dos deveres fiduciários: "Que resultado, porém, se consegue, dessa medida [constituição de sociedades anônimas sob o regime da liberdade contratual], se a lei não tem o poder de regulamentar a consciência dos homens e tudo depende da probidade dos indivíduos, do meio em que exercem a sua atividade e do valor moral e científico de uma Magistratura compenetrada da sua missão?" (CARVALHO DE MENDONÇA, José Xavier. Tratado de direito comerccial brasileiro. v. 3. $5^{\text {a }}$ ed. Atual. por Achilles Bevilaqua e Roberto Carvalho de Mendonça. Rio de Janeiro: Freitas Bastos, 1954, p. 276).

${ }^{207}$ Segundo CARVAlHOSA, a LSA “prescreve alguns padrões de comportamento do administrador. Neles estão implícitos modelos e combinações de elementos que fornecem a linha de conduta subjetiva que deve ser observada pelo administrador. Tais Standards são amplos, flexíveis e capazes, portanto, de abranger variadas situações, conforme as circunstâncias e peculiaridades de cada caso." (CARVALHOSA, Modesto. Comentários à lei das sociedades anônimas. $5^{\mathrm{a}}$ ed. São Paulo: Saraiva, 2011. vol. 3, p. 272).

208 "a fidúcia em seu sentido técnico-jurídico corresponde ao sentido original da raiz etimológica do termo, de confiança (trust). (...) Ela significa que o credor adquire mais direitos que precisaria para garantir seus direitos" (SALOMÃO FILHO, Calixto. O Novo Direito Societário. 4ª ed. São Paulo: Malheiros, 2011, p. $191)$.

209 “(...) do ponto de vista prático, a discricionariedade se justifica para evitar o automatismo e porque seria inviável para o legislador prever todas as situações possíveis. (...) Com efeito, diante da inevitabilidade da discricionariedade, ganha importância o dever de diligência, necessário à limitação da atuação dos administradores e à garantia de que estes irão exercer corretamente a sua função." (PATELLA, Laura Amaral; BORES, Leandro Vilarinho; BERNARDES, Lucas Petri; AZEVEDO, Luís André Negrelli de Moura. Deveres Fiduciários dos Administradores. Vinculação dos Administradores. In Mercado de Capitais Brasileiro: Doutrina, Cases e Materials. São Paulo: Quartier Latin, 2012, p. 237).
} 
Nesse sentido, a Seção V da $\operatorname{LSA}^{210}$ prevê uma série de deveres fiduciários aos administradores $^{211}$, dentre os quais se destaca o dever de observar a finalidade de suas atribuições (também denominado pela doutrina como dever de independência e, por nós aqui referenciado em algumas passagens, como o dever de proteção do interesse social), previsto no art. $154, \S 1^{\circ}$ :

Art. 154. O administrador deve exercer as atribuições que a lei e o estatuto lhe conferem para lograr os fins e no interesse da companhia, satisfeitas as exigências do bem público e da função social da empresa ${ }^{212}$.

$\S 1^{\circ} \mathrm{O}$ administrador eleito por grupo ou classe de acionistas tem, para com a companhia, os mesmos deveres que os demais, não podendo, ainda que para defesa do interesse dos que o elegeram, faltar a esses deveres. (destaques nossos)

A leitura do dispositivo legal acima deixa claro que independentemente do que ocorra na realidade de governança da companhia, o administrador guardará sempre o dever de observar o interesse da companhia (conforme definido no Capítulo III acima) ${ }^{213}$. Interessante notar, todavia, o entendimento da CVM sobre os conselheiros eleitos como representantes de empregados nos termos do artigo 140, parágrafo único, da LSA. Segundo a autarquia, a estes conselheiros seria facultado agir no interesse daqueles que o elegeram e não no da companhia ${ }^{214}$ em caso de conflito.

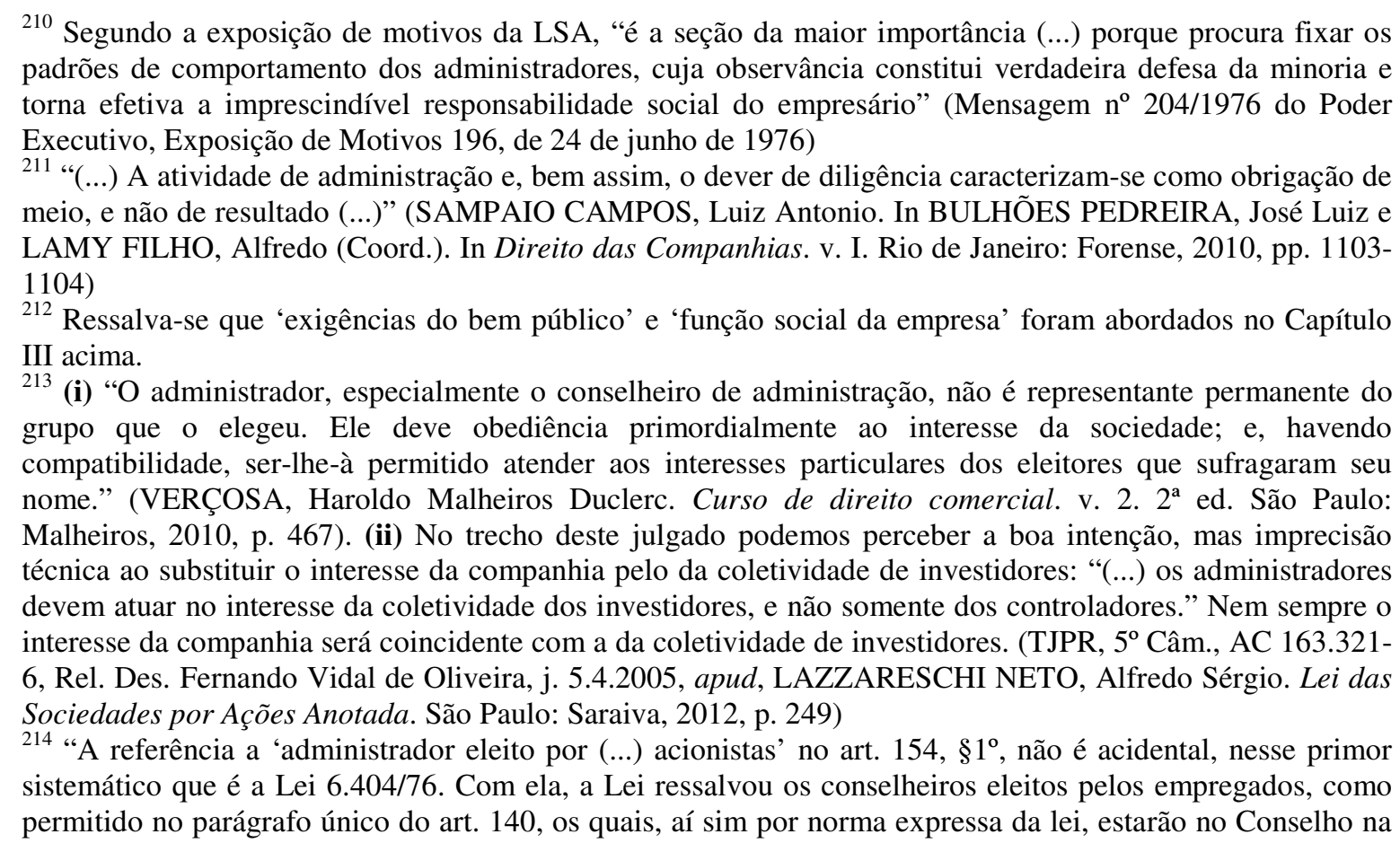


Trata-se, acima de tudo, de um poder (dever) finalístico atribuído pela lei em razão de sua relação de fidúcia (confiança) direta com a companhia e indireta com os detentores do capital. O fato é que ao administrador foi confiada a função de zelar por um patrimônio alheio e considerando que a companhia é um ente personificado e distinto de seus acionistas, nada mais apropriado do que estabelecer ao administrador o dever de buscar e privilegiar o interesse da companhia em si.

Em função deste poder (dever) finalístico, a lei não permite que o administrador privilegie qualquer outro interesse que não seja o da companhia, especialmente o do acionista que o elegeu ${ }^{215}$.

Tendo em vista nossa realidade de concentração de capital e o fato de os acionistas poderem destituir os administradores a qualquer tempo, percebe-se que a lei colocou o administrador em uma difícil situação, pois em sua atividade estará sempre diante de duas possibilidades inibidoras, a (objetiva) demissão ad nutum e a (subjetiva) potencial responsabilização por não observância do interesse da companhia.

Como a primeira (demissão ad nutum) representa uma possibilidade muito mais concreta e factível de acontecer e contra a segunda, entre outros fatores, disseminou-se a contratação de seguros de responsabilidade civil de administradores ( $D \& O$ s), na prática são poucos os incentivos a uma atuação conscienciosa do administrador em benefício do interesse da companhia ${ }^{216}$.

qualidade de 'representantes dos empregado', e, portanto, autorizados a votar de acordo com os interesses destes, quando conflitantes - se isto ocorrer - com os da companhia" (Colegiado da CVM, Proc. RJ 2007/0191, Reg. 5384/2007, voto do Presidente Marcelo Trindade, j. 23.1.2007, apud, LAZZARESCHI NETO, Alfredo Sérgio. Lei das Sociedades por Ações Anotada. São Paulo: Saraiva, 2012, pp. 447).

215 "O administrador culpado da violação de algum dos deveres específicos que a lei lhe impôs não se escusa alegando o cumprimento de ordens dos acionistas, ou o adimplemento de obrigações assumidas com estes. Nem mesmo quando representante eleito de grupo ou classe de acionistas, como precisa o art. $154, \S 1^{\circ}$, pode o administrador eximir-se do cumprimento dos seus deveres próprios, que são idênticos para todos os administradores." (COMPARATO, Fábio Konder. Novos ensaios e pareceres de direito empresarial. Rio de Janeiro: Forense, 1981, p. 99).

216 “(...) por mais que se saiba da obrigação dos membros do conselho de administração de colocarem o interesse da sociedade como uma prioridade acima de qualquer outra, de fato exercem sua função como delegados do controlador." (VERÇOSA, Haroldo Malheiros Duclerc. Curso de direito comercial. v. 2. $2^{\mathrm{a}}$ ed. São Paulo: Malheiros, 2010, p. 225). 
Assim, sob essa ótica, os deveres dos administradores seriam primordialmente para com a companhia ${ }^{217}$ e não para com o acionista que o indicou ${ }^{218} \mathrm{e}$, independentemente da matéria deliberada pela administração, seus membros devem agir conforme sua própria consciência e diligência para dar efetivo cumprimento a seus deveres fiduciários, seja o de proteção do interesse social, seja os demais deveres ${ }^{219}$, quais sejam:

(i) dever de diligência (artigo 153); i.e., o administrador deve empregar o cuidado e diligência que todo homem ativo e probo emprega em seus próprios negócios ${ }^{220}$;

${ }^{217}$ ADAMEK observa que “(...) ao contrário do que sucede no direito inglês, os deveres fiduciários dos administradores existem não somente para com a companhia, mas, em certas situações impõem-se, inclusive, para com os acionistas e os investidores (...)", como é o caso, e.g., do dever de informar previsto no artigo 157 da LSA. (VON ADAMEK, Marcelo Vieira. Responsabilidade dos Administradores de S.A. e as Ações Correlatas. São Paulo: Saraiva, 2009, p. 108). Todavia, o jurista reconhece que em regra os deveres existem em relação à companhia: "Os deveres de índole fiduciária (como os de diligência e lealdade), pelo texto da lei, obrigam os administradores para com a companhia, apenas. Em princípio, portanto, não existe o dever de lealdade do administrador para com o sócio, a não ser indiretamente (isto é, na medida em que o interesse do sócio identifique-se com aquele da própria sociedade), como dever geral de lealdade societária" (VON ADAMEK, Marcelo Vieira. Responsabilidade dos Administradores de S.A. e as Ações Correlatas. São Paulo: Saraiva, 2009, pp. 120 e 121).

${ }^{218}$ Nesse sentido, (i) VALLADÃO afirma que: "Nas sociedades de capitais, (...) dá-se algo completamente diverso, pois a gestão da atividade empresarial se autonomiza, competindo exclusivamente aos administradores, que são totalmente independentes da assembleia dos acionistas" (grifos nossos) (FRANÇA, Erasmo Valladão e Azevedo Novaes. Dever de Informar dos Administradores de Companhias Abertas. Inexistência de Submissão ao Acionista Controlador. In Temas de Direito Societário, Falimentar e Teoria da Empresa. São Paulo: Malheiros, 2009, pp. 363-370); (ii) ADAMEK afirma ainda que se após as alterações feitas à LSA em 2001 a vinculação tornou-se indisputável, "também o é a necessidade de interpretar as disposições da Lei das S.A. de forma sistemática para, assim, concluir que, a despeito das novas regras, o administrador eleito por grupo ou classe de acionistas continua a ter, para com a companhia, os mesmos deveres que os demais (LSA, art. $154, \S 1^{\circ}$ ) e que, mais do que isso, as competências do órgão ao qual pertence continuam a ser privativas e indelegáveis (LSA, art. 139)" (VON ADAMEK, Marcelo Vieira. Responsabilidade dos Administradores de S.A. e as Ações Correlatas. São Paulo: Saraiva, 2009, p. 145); e (iii) "O administrador deve ter liberdade para exercer suas competências, inclusive afastando a decisão se entender que ela não é a que melhor promove o interesse social" (ABREU, Jorge Manoel Coutinho de. Governança das sociedades comerciais. $2^{\mathrm{a}}$ ed. Coimbra: Almedina, 2010, p. 110).

219 “(...) o dever de diligência pode ser desmembrado em pelo menos cinco outros deveres relativamente distintos: dever de se qualificar, dever de bem administrar, dever de se informar, dever de investigar e dever de vigiar" (Colegiado da CVM, PAs 25/03, Rel. Diretor Eli Loria, j. 25.3.2008). Além disso: “(...) a CVM aceita como subsídio as decisões dos Tribunais norte-americanos: 'Na ausência de decisões prévias ou de reflexões sobre o assunto no Brasil, a jurisprudência norte-americana pode servir como um bom subsídio, especialmente porque lá se procura extrair conceitos e regras a partir de casos concretos." (PAS CVM RJ 2005/1443, em 10.05.2006, Rel. Dir. Pedro Oliva Marcílio de Sousa, apud EIZIRIK, Nelson; GAAL, Ariádna B.; PARENTE, Flávia; HENRIQUES, Marcus de Freitas. Mercado de Capitais. Regime Jurídico. $3^{\text {a }}$ ed. rev. e ampl. Rio de Janeiro: Renovar, 2011, p. 428).

${ }^{220}$ (i) CARVALHOSA critica o padrão de diligência adotado pela LSA: "Não basta, em nosso direito, por sua inquestionável feição institucional, que o administrador atue como homem ativo e probo na condução de seus próprios negócios. São insuficientes os atributos de diligência, honestidade e boa vontade para qualificar as pessoas como administradores. É necessário que se acrescente a competência profissional específica, traduzida por escolaridade ou experiência e, se possível, ambas. O próprio art. 152 expressamente estabelece esses requisitos, ao falar em competência, reputação profissional e tempo de dedicação às funções." CARVALHOSA, Modesto. Comentários à lei das sociedades anônimas. $5^{\text {a }}$ ed. São Paulo: Saraiva, 2011. vol. 3, p. 272). (ii) Também neste sentido, ADAMEK afirma que: "Em outros países, o padrão de comportamento adotado na caracterização do dever de diligência tem sido diverso. Na Itália, por exemplo, (...) é feita alusão "à diligência requerida pela natureza de sua função e de sua específica competência" (CC 
(ii) dever de lealdade (artigo 155), i.e., o administrador deve servir com lealdade à companhia e manter reserva sobre os seus negócios ${ }^{221}$;

(iii) dever de evitar situações de conflito de interesses (artigo 156), i.e., é vedado ao administrador intervir em qualquer operação social em que tiver interesse conflitante com o da companhia, podendo contratar com a companhia somente em condições razoáveis ou equitativas $^{222}$; e

(iv) dever de informar (artigo 157), i.e., os administradores de companhia aberta são obrigados a, por exemplo, comunicar à bolsa de valores e a divulgar pela imprensa qualquer deliberação da assembleia-geral ou da administração, ou fato relevante ocorrido nos seus negócios, que possa influir na decisão dos investidores do mercado de vender ou comprar valores mobiliários emitidos pela companhia ${ }^{223}$.

it., art. 2.392). Já na Alemanha, o legislador adota o critério da diligência de diretor de empresa consciencioso (AktG de 1965, § 93), mais específico e consentâneo com a importância das grandes companhias na economia. Em Portugal, há menção à diligência "de um gestor criterioso e ordenado" (CSC, art. 64). Na Argentina, mencionam-se a lealdade e a diligência "de um buen hombre de negocios" (LSC, art. 59). Na Suiça, é feita alusão à necessidade de atuar "com toda diligência" (mit aller Sorgfalt), sem referência expressa a padrão comparativo (...). Na Inglaterra, decidiu-se que um diretor deve exibir na execução de suas tarefas pelo menos o grau de diligência que pode ser esperado de uma pessoa com o seu conhecimento e experiência. E, nos Estados Unidos da América, entende-se que "a regra mais justa e satisfatória é o grau de cuidado e diligência que um diretor ordinariamente prudente deveria razoavelmente exercer numa posição semelhantes sob circunstâncias similares" (VON ADAMEK, Marcelo Vieira. Responsabilidade dos Administradores de S.A. e as Ações Correlatas. São Paulo: Saraiva, 2009, pp. 122 e 123).

${ }^{221}$ (i) VeRÇOSA ensina que: "O dever de lealdade previsto no art. 155 da LSA predomina soberano sobre a relação de obediência que o conselheiro eleito por grupo de acionistas pudesse ter em relação a estes. (...)" (VERÇOSA, Haroldo Malheiros Duclerc. Curso de direito comercial. v. 3. $2^{\mathrm{a}}$ ed. São Paulo: Malheiros, 2011, p. 433). (ii) ADAMEK acrescenta que: "O dever de sigilo, previsto conjuntamente com o de lealdade no art. 155, caput, da Lei das S.A., possui duas facetas: a genérica, caracterizada pela obrigação de o administrador manter reserva sobre os negócios sociais, e a específica, aplicável somente ao administrador de

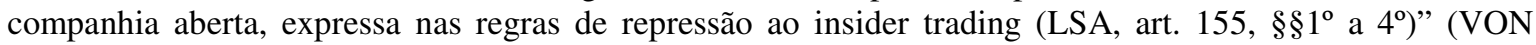
ADAMEK, Marcelo Vieira. Responsabilidade dos Administradores de S.A. e as Ações Correlatas. São Paulo: Saraiva, 2009, p. 167).

${ }^{222}$ Sobre o dever de evitar situações de conflito de interesse, "no julgamento do Processo no RJ 2004/5494, relatado por Wladimir Castelo Branco Castro, em 16.12.2004, foi firmado o entendimento, extraído do voto do relator, de que o impedimento imposto ao administrador pelo artigo 156 é de caráter pessoal: '(...) Conclui-se, portanto, que o conflito de interesses é, no caso do art. 156 da Lei 6.404/76, presumido, isto é, independe da análise do caso concreto a sua aplicação, restando os administradores da companhia uma determinada operação em que figure como contraparte da companhia ou pela qual seja beneficiado, independentemente se está a se perseguir o interesse social ou não'." (EIZIRIK, Nelson; GAAL, Ariádna B.; PARENTE, Flávia; HENRIQUES, Marcus de Freitas. Mercado de Capitais. Regime Jurídico. $3^{\mathrm{a}}$ ed. rev. e ampl. Rio de Janeiro: Renovar, 2011, p. 476).

${ }^{223}$ (i) Sobre o artigo 157 da LSA, SAMPAIO CAMPOS afirma que "A primeira observação é a de que os deveres previstos no artigo 157 são restritos aos administradores de companhias abertas e, em princípio, não se estendem às companhias fechadas." (SAMPAIO CAMPOS, Luiz Antonio. In BULHÕES PEDREIRA, José Luiz e LAMY FILHO, Alfredo (Coord.). In Direito das Companhias. v. I. Rio de Janeiro: Forense, 2010, p. 1171). (ii) Sobre o fundamento do dever de informar, FRANCO e SZTAJN ensinam que: "No pano de fundo, fundamentos da proibição são a tutela da eficiência valorativa do mercado; o respeito ao princípio da transparência (full disclosure), e aquele da moralidade que veda a formação de canais privilegiados" 
Analisados os deveres fiduciários da administração, como nota final, destacamos o comentário de ADAMEK, extraído de seu rico trabalho sobre responsabilidade de administradores de sociedades anônimas, com o qual estamos amplamente de acordo:

Daí por que, mesmo correndo o risco de ser tachado de "prolixo e repetitivo", o legislador deliberadamente optou por ser detalhista e esmiuçar ao máximo os padrões de comportamento desejados, nos arts. 153 a 158 da lei acionária. E, por isso, não deveria merecer críticas. A censura que se poderia fazer à Lei das S.A. é de que as suas normas não são efetivas (...), embora, quanto a isso, não seja razoável imputar ao legislador culpa exclusiva por problemas claramente estruturais do Poder Judiciário e de formação dos profissionais da área jurídica. ${ }^{224}$

\subsection{Competência privativa e o princípio da indelegabilidade}

O segundo aspecto que analisaremos sobre os administradores é o escopo de sua atuação (i.e., suas competências privativas atribuídas pela LSA e pelo estatuto social), bem como o princípio da indegabilidade de funções.

Na lição de BARRETO FILHO:

a lei [LSA] passa a reconhecer aos administradores poderes exclusivos não derivados da assembleia ou por ela avocáveis. Afirma-se, cada vez mais, o caráter orgânico, e não contratual da administração. ${ }^{225}$

Na LSA, as competências privativas do conselho de administração estão dispostas no art. $142^{226}$, e as da diretoria, no art. $144^{227}$. Além disso, o estatuto social também possui

(FRANCO, Vera Helena de Melo; SZTAJN, Rachel. Direito Empresarial II: sociedade anônima, mercado de valores mobiliários. $2^{\mathrm{a}}$ ed. ver. atual. e ampl. São Paulo: Revista dos Tribunais, 2009, p. 184).

${ }^{224}$ VON ADAMEK, Marcelo Vieira. Responsabilidade dos Administradores de S.A. e as Ações Correlatas. São Paulo: Saraiva, 2009, p. 119.

${ }^{225}$ BARRETO FILHO, Oscar. Estrutura Administrativa das Sociedades Anônimas. In Revista de Direito Mercantil, Industrial, Econômico e Financeiro. n 24, pp. 65-74, p. 70.

226 “Art. 142. Compete ao conselho de administração: I. fixar a orientação geral dos negócios da companhia; II. eleger e destituir os diretores da companhia e fixar-lhes as atribuições, observado o que a respeito dispuser o estatuto; III. fiscalizar a gestão dos diretores, examinar, a qualquer tempo, os livros e papéis da companhia, solicitar informações sobre contratos celebrados ou em via de celebração, e quaisquer outros atos; IV. convocar a assembléia-geral quando julgar conveniente, ou no caso do artigo 132; V. manifestar-se sobre o relatório da administração e as contas da diretoria; VI. manifestar-se previamente sobre atos ou contratos, quando o estatuto assim o exigir; VII. deliberar, quando autorizado pelo estatuto, sobre a emissão de ações 
ampla liberdade para adicionar competências à assembleia, ao conselho e à diretoria, que não tenham sido por lei conferidas a outro órgão ${ }^{228}$. Tais matérias estatutárias também possuem natureza privativa, aplicando-se, portanto, os mesmos entendimentos e regras dedicados às matérias privativamente estabelecidas pela lei ${ }^{229}$.

Do rol de matérias do art. 142 da LSA, existem aquelas que a própria lei autoriza que o estatuto disponha de forma diversa ${ }^{230}$. Nesses casos, doutrina e jurisprudência ${ }^{231}$ não se posicionam claramente sobre a possibilidade de o estatuto poder apenas especificar mais detalhes sobre tais competências ou, inclusive, prever que elas sejam exercidas por outro órgão social.

WALD e BOCATER e CAMARGO, por exemplo, concordam que as seguintes matérias, previstas no art. 142 da LSA, incisos VI ("manifestar-se previamente sobre atos ou contratos, quando o estatuto assim o exigir”), VII (“deliberar, quando autorizado pelo estatuto, sobre a emissão de ações ou de bônus de subscrição") e VIII ("autorizar, se o

ou de bônus de subscrição; VIII. autorizar, se o estatuto não dispuser em contrário, a alienação de bens do ativo não circulante, a constituição de ônus reais e a prestação de garantias a obrigações de terceiros; IX. escolher e destituir os auditores independentes, se houver". (destaques nossos)

227 “Art. 144. No silêncio do estatuto e inexistindo deliberação do conselho de administração (artigo 142, n. II e parágrafo único), competirão a qualquer diretor a representação da companhia e a prática dos atos necessários ao seu funcionamento regular".

228 “(...) à medida que, não havendo interferência na esfera de atribuições legais de outro órgão, podem os estatutos da companhia, ou mesmo o regimento interno do conselho, conferir-lhe outras funções, além de especificar e pormenorizar as existentes". (TOLEDO, Paulo F. C. Salles de. O Conselho de Administração na sociedade anônima. $2^{a}$ ed. São Paulo: Atlas, 1999, p. 37)

${ }^{229}$ EIZIRIK ensina que: "O estatuto social, como lei interna da companhia, pode criar outras hipóteses de deliberação privativa da assembleia geral, conforme o interesse da companhia. (...) Caso o estatuto social proceda dessa forma, atribuindo a determinado órgão social a competência sobre uma matéria específica, esta reserva de competência deve ser necessariamente observada pelos acionistas, uma vez que as normas estatutárias possuem força de direito inerente ao agrupamento, isto é, têm natureza obrigatória, devendo ser permanentemente respeitadas por todos os acionistas." (EIZIRIK, Nelson. A Lei das S.A. Comentada. Volume II - Arts. 121 a 188. São Paulo: Quartier Latin, 2011, p. 22) Concordamos parcialmente com o entendimento acima, tendo em vista o fato de que o estatuto social (e o acordo de acionistas, como se verá adiante) não poder versar sobre matérias de competência privativa de outros órgãos.

230 "II. eleger e destituir os diretores da companhia e fixar-lhes as atribuições, observado o que a respeito dispuser o estatuto; VI. manifestar-se previamente sobre atos ou contratos, quando o estatuto assim o exigir; VII. deliberar, quando autorizado pelo estatuto, sobre a emissão de ações ou de bônus de subscrição; VIII. autorizar, se o estatuto não dispuser em contrário, a alienação de bens do ativo não circulante, a constituição de ônus reais e a prestação de garantias a obrigações de terceiros".

${ }^{231}$ Vide a interpretação conferida no seguinte julgado (com a qual não concordamos), de que a assembleia, como órgão máximo da companhia, pode avocar quaisquer matérias atribuídas em lei para outros órgãos: "Em caso em que o estatuto da companhia dava competência aos administradores para deliberar sobre aumento de capital através da emissão de ações até o limite de $30 \%$ do próprio capital social, o Tribunal de Justiça de São Paulo decidiu: 'Mas, evidentemente, tal competência não exclui a competência da assembleia geral, como órgão soberano da sociedade, de deliberar sobre o mesmo assunto. Em verdade, a competência do Conselho Diretor configura-se em faculdade de atuar, que não pode conflitar com a competência do órgão máximo de deliberação da sociedade, a assembleia geral, esta com poderes para ratificar ou não todos os atos que interessam à sociedade'." (Apelação Cível n. 119.219-1, Rel. Desembargador Godofredo Mauro, TJ-SP). 
estatuto não dispuser em contrário, a alienação de bens do ativo não circulante, a constituição de ônus reais e a prestação de garantias a obrigações de terceiros") poderiam ser objeto de vinculação dos administradores em acordo de acionistas, mas nada comentam sobre a possibilidade de tais matérias serem deliberadas por, ou atribuídas no estatuto a, outro órgão social ${ }^{232}$.

Com relação ao inciso II do art. 142 da LSA ("eleger e destituir os diretores da companhia e fixar-lhes as atribuições, observado o que a respeito dispuser o estatuto"), WALD se posiciona contrariamente à sua vinculação em acordo de acionistas. Podemos extrair de seu posicionamento, por decorrência lógica, que a assembleia não poderia eleger diretores, tampouco o estatuto outorgar essa competência a outro órgão ${ }^{233}$.

Partilhamos da opinião de WALD manifestada nos últimos dois parágrafos e aproveitamos para nos posicionar acerca da possibilidade de a assembleia geral deliberar sobre, e o estatuto atribuir a outro órgão social, as matérias previstas no art. 142. Entendemos que somente os incisos VI, VII e VIII poderiam ser objeto de deliberação em assembleia ou delegados a outro órgão no estatuto social da companhia. Os demais incisos representam, portanto, competência privativa do conselho de administração, de forma que o estatuto social somente poderia especificar mais informações sobre eles, mas não contrariá-los, tampouco transferi-los a outro órgão.

A lei concedeu tratamento distinto às competências da diretoria ${ }^{234}$. Trata-se de um órgão de competência residual que tem por função privativa precípua a representação da companhia (art. 144, da LSA). Exceto por CALIXTO SALOMÃO ${ }^{235}$, a doutrina ainda não se ${ }^{232}$ WALD, Arnoldo. A evolução do regime do conselho de administração, os acordos de acionistas e os
impedimentos dos conselheiros decorrentes de conflito de interesses. In Revista de Direito Bancário, do
Mercado de Capitais e da Arbitragem. n 11 . São Paulo: Revista dos Tribunais, pp. 13-30 e CAMARGO,
João Laudo; BOCATER, Maria Isabel do Prado. Conselho de Administração: seu Fucionamento e
Participação de Membros Indicados por Acionistas Minoritários e Preferencialistas. In LOBO, Jorge
(Coord.). Reforma da Lei das Sociedades Anônimas. $2^{a}$ ed. Rio de Janeiro: Forense, 2002. p 400.
233 "Se existente o Conselho, só ele pode eleger os diretores, sem embargo do poder que detém a assembleia
de instruí-lo a os substituir.” (TEPPEDINO, Ricardo. In BULHÕES PEDREIRA, José Luiz; LAMY FILHO,
Alfredo (Coord.). In Direito das Companhias. v. I. Rio de Janeiro: Forense, 2010, p. 882)
234 “As mesmas conclusões a que chegamos em relação ao dever da administração de dar cumprimento às
deliberações da assembleia geral aplicam-se ao dever de a diretoria atender às determinações emanadas do
conselho de administração." (ADAMEK, Marcelo Vieira. Responsabilidade civil dos administradores de S/A
e as ações correlatas. São Paulo: Saraiva, 2009, p. 141)
235 “A indelegabilidade de certas funções faria e faz todo o sentido desde que os órgãos da base da pirâmide
(leia-se diretoria) também dispusessem de competências privativas. Não é o que ocorre. Além de não dispor
de competência privativa, a diretoria pode ter sua decisão a qualquer momento avocada pela assembleia 
manifestou sobre a possibilidade de uma matéria não atribuída à assembleia geral ou ao conselho de administração, considerada, portanto, como de competência residual da diretoria, poderia ser avocada por tais órgãos.

A nosso ver, a resposta correta dependeria da previsão estatutária, i.e., se silente sobre a matéria, ainda que a diretoria seja competente para exercê-la residualmente, seria plena e naturalmente possível que a assembleia geral ou o conselho de administração deliberassem sobre ela. Não queremos dizer, com isso, que a diretoria deveria obrigatoriamente consultar tais órgãos. Pelo contrário, a matéria omissa somente seria objeto de deliberação em assembleia ou conselho, se esses órgãos identificassem previamente tal necessidade, ou se assim desejasse a diretoria.

Esse entendimento justifica-se no simples fato de nem a lei, nem o estatuto, terem regulado a matéria, bem como na natureza hierarquicamente superior das funções da assembleia geral e do conselho de administração, em relação à diretoria.

Nos termos do art. 139 da LSA, "as atribuições e poderes conferidos por lei aos órgãos de administração não podem ser outorgados a outro órgão, criado por lei ou pelo estatuto" 236 .

Nas lições de COMPARATO:

geral, que pode decidir soberanamente sobre qualquer questão social (art. 121). Não há, portanto, o menor traço de independência funcional da diretoria." (SALOMÃO FILHO, Calixto. O Novo Direito Societário. $4^{\mathrm{a}}$ ed. São Paulo: Malheiros, 2011, p .102)

${ }^{236}$ Vide as opiniões de VERÇOSA, CARVALHOSA e do extrato de um julgado a esse respeito, respectivamente: (i) "Os órgãos da sociedade recebem competência específica e indelegável, não podendo um deles invadir a esfera de atribuições do outro, sob pena de responsabilidade por quem assim o fez ou tolerou que se fizesse. (...) O princípio é válido para todos os órgãos sociais: a assembleia-geral ou a reunião de sócios não pode administrar; os administradores não podem deliberar em lugar dos sócios; o conselho fiscal não pode gerir a sociedade; etc." (VERÇOSA, Haroldo Malheiros Duclerc. Curso de direito comercial. v. 3. 2a ed. São Paulo: Malheiros, 2011, p 187) (ii) “(...) [os poderes atribuídos aos administradores pela lei ou pelo estatuto] (s)ão próprios, pois advêm da lei e não são delegados por qualquer outro órgão societário. Esses poderes exclusivos não podem ser avocados sequer pela assembleia geral, que representa a vontade soberana da companhia. Isto porque os poderes dos órgãos de administração não são delegados por ela, assembleia geral, mas advêm diretamente da lei." (CARVALHOSA, Modesto. Comentários à lei das sociedades anônimas. v. 3. $5^{\mathrm{a}}$ ed. São Paulo: Saraiva, 2011, p. 42) (iii) "O art. 139 da Lei das S.A. que orientou o pleito dos Reqtes., consigna que as atribuições e poderes conferidos aos administradores não podem ser outorgados a outro órgão (...)”. (TJDF, 2 ${ }^{\mathrm{a}}$ T., AC 2001011047155-8, Rel. Des. Waldir Leôncio Júnior, j. 21.2.2005, apud, LAZZARESCHI NETO, Alfredo Sérgio. Lei das Sociedades por Ações Anotada. São Paulo: Saraiva, 2012, p. 389) 
onde há competência privativa há também, por via de estrita consequência, a indelegabilidade de poderes ou funções (...). A regra [art. 139] decorre, naturalmente, do princípio da exclusividade de competências, que na história do direito político tem nome de 'princípio da divisão dos Poderes' (...). A razão, afinal, reside na perfeita incompatibilidade entre competência privativa e delegabilidade de funções. A admitir-se esta última, estar-se-ia suprimindo, logicamente, o caráter exclusivo da atribuição de poderes. Pois a função que pareceu ao legislador não pudesse ser exercida por mais ninguém, a não ser o titular nomeado, passaria, por vontade deste, a ser atuada por outrem. Onde a lei inscreveu 'privatividade', o destinatário da atribuição leria; 'transmissibilidade' ao seu alverdrio. $\mathrm{O}$ abuso de poderes seria chocante. ${ }^{237}$

No contexto da teoria organicista e da visão moderna de soberania da assembleia geral, e a partir de referido dispositivo legal, a doutrina majoritária tem entendido que as atribuições conferidas por lei ou pelo estatuto a um órgão social não podem ser delegadas ou exercidas por outro órgão, nem mesmo pela própria assembleia geral ${ }^{238}$.

A opinião prevalecente é a de que a competência privativa do administrador é conferida pela lei e não pela assembleia geral, não justificando, portanto, sua avocação pelo órgão máximo da companhia ${ }^{239}$. Ademais, a competência atribuída por lei tem natureza de norma cogente e de ordem pública, não podendo, portanto, ser renunciada ou contrariada $^{240}$.

\footnotetext{
${ }^{237}$.COMPARATO, Fábio Konder. Competência privativa do conselho de administração para designação de diretores, em companhia aberta: ineficácia de cláusula de contrato social da holding, ou de eventual acordo de acionistas, para regular a matéria. In Novos ensaios e pareceres de direito empresarial. Rio de Janeiro: Forense, 1981, pp. 96-97.

238 "Salvo, portanto, em relação às poucas matérias em que a lei expressamente admite a regulação pelo estatuto, o regime legal da organização da companhia é constituído de normas cogentes: a competência privativa da assembleia geral não pode ser exercida por outros órgãos; as atribuições e poderes conferidos pela lei aos órgãos da administração não podem ser outorgados a outro órgão, criado por lei ou pelo estatuto (art. 139) (....." (BULHÕES PEDREIRA, José Luiz; LAMY FILHO, Alfredo. In Direito das Companhias. v. I. Rio de Janeiro: Forense, 2010, p. 803)

239 "Não são impositivas, por evidente, as deliberações usurpadoras de competência privativa de órgão da administração e aquelas violadoras da lei e dos estatutos que, em sendo cumpridas, possam redundar na responsabilidade pessoal do administrador. A lei acionária alemã, neste ponto (assim como em vários outros), foi mais precisa, pois consigna expressamente ser dever da diretoria cumprir deliberação da assembleia geral 'no âmbito da sua competência', isto é, da própria assembleia (cf.: AktG §83)." (ADAMEK, Marcelo Vieira. Responsabilidade civil dos administradores de S/A e as ações correlatas. São Paulo: Saraiva, 2009, p. 139)

240 "As normas que tratam da competência dos órgãos são cogentes, de ordem pública, não sendo possível aos particulares apartarem-se delas. Assim, as atribuições privativas da assembleia geral, do conselho de administração, dos diretores e do conselho fiscal são previstas na Lei das S.A., não podendo o estatuto dispor em contrário, sob pena de não terem, tais regras, qualquer efeito jurídico." (EIZIRIK, Nelson. A Lei das S.A. Comentada. Volume II - Arts. 121 a 188. São Paulo: Quartier Latin, 2011, p 262)
} 
ADAMEK vai mais longe e afirma que:

o administrador que se submete à deliberação de outro órgão, usurpadora de sua competência, está, reversamente, consentindo em delegar funções privativas (e, portanto, indelegáveis). Estaria, só por isso, concorrendo para a prática de ato ilícito, violador da lei (LSA, art. 158, II). Mais do que isso, estaria sendo passivo, antônimo de ativo, como se exige do administrador diligente (LSA, art. 153). ${ }^{241}$

O entendimento transcrito neste subcapítulo, sobre competência privativa e indelegabilidade, parece ser partilhado pelas principais leis estrangeiras, conforme apontam as lições de COMPARATO e ADAMEK, respectivamente:

(...) no direito inglês, a partir do precedente Automatic SelfCleansing Filter Syindicate Co. v. Cuningham (...) [os] tribunais passaram a reconhecer, como salientou Gower, que a repartição de poderes entre assembleia e o órgão administrativo assemelha-se à partilha de competências num Estado federal, com os poderes residuais pertencendo, sempre, aos diretores. Em especial, a gestão dos negócios sociais (management) é atribuição exclusiva dos administradores, sendo ilícita, por exemplo, uma resolução da assembleia geral que determine a venda de um bem classificado no ativo realizável da companhia, contra a opinião dos diretores. ${ }^{242}$

(...) segundo informa Yves Guyon, na França os tribunais têm decidido, corretamente, que a assembleia geral não pode exercer diretamente as atribuições do conselho de administração (...). $\mathrm{Na}$ Itália, Francesco Galgano também observa que "l'assemblea no puó avocare a sé l'amministrazione, NE puó impartire agli amministratori direttive, né puó revocare i loro atti'. O princício é universal. $^{243}$

\subsection{Independência de conselheiros, as boas práticas de governança, conselheiros independentes e o papel da autorregulação}

\footnotetext{
${ }^{241}$ ADAMEK, Marcelo Vieira. Responsabilidade civil dos administradores de S/A e as ações correlatas. São Paulo: Saraiva, 2009, p. 140.

${ }^{242}$ COMPARATO, Fábio Konder. Competência privativa do conselho de administração para designação de diretores, em companhia aberta: ineficácia de cláusula de contrato social da holding, ou de eventual acordo de acionistas, para regular a matéria. In Novos ensaios e pareceres de direito empresarial. Rio de Janeiro: Forense, 1981, p. 104.

${ }^{243}$ ADAMEK, Marcelo Vieira. Responsabilidade civil dos administradores de S/A e as ações correlatas. São Paulo: Saraiva, 2009, pp. 16-17.
} 


\title{
5.3.1. Independência de conselheiros ${ }^{244}$
}

Usualmente atrelado ao dever fiduciário previsto no art. $154, \S 1^{\circ}$ da LSA, diversos doutrinadores vislumbram um dever de independência dos membros do conselho de administração. Isso porque o texto legal menciona expressamente que o administrador não pode privilegiar os interesses daquele que o elegeu, em prejuízo do interesse da companhia.

Cumpre-nos diferenciar o dever de independência de conselheiros do conceito de conselheiros independentes. Segundo CERAZETTI ${ }^{245}$ “(...) a independência deve ser entendida como regra aplicável a todos os administradores, e não apenas àqueles qualificados como 'independentes'." Assim, independência é um dever atribuído a todos os conselheiros, e os conselheiros independentes em si não ostentam tal qualificação, não por acatar esse dever que já é comum à sua função, mas pelo seu distanciamento dos acionistas e da companhia (conforme definição adotada por cada regulador).

Após esse esclarecimento, retomamos o estudo do dever de independência do conselheiro. Na opinião de VERÇOSA:

\begin{abstract}
A independência dos administradores (na qual incluo a independência do conselheiro fiscal) acresce o rol dos princípios da governança corporativa e está ligada à adoção do sistema organicista. Tem-se que, desta forma, os membros dos órgãos societários (...) não são representantes dos que os elegeram, segundo a ideia do exercício de um mandato. ${ }^{246}$
\end{abstract}

\footnotetext{
${ }^{244}$ Como justificativa do título restritivo deste subcapítulo: "É o conselho de administração, portanto, o órgão societário que desperta a maior atenção dos estudiosos das hoje denominadas 'boas práticas de governança', pois é nele que - como órgão colegiado situado em posição intermediária, entre os donos do capital, de um lado, e os diretores executivos, de outro - se concentram os poderes de zelar pelos interesses da companhia." (CAMARGO, João Laudo; BOCATER, Maria Isabel do Prado. Conselho de Administração: seu Funcionamento e Participação de Membros Indicados por Acionistas Minoritários e Preferencialistas. In LOBO, Jorge (Coord.). Reforma da Lei das Sociedades Anônimas - Inovações e Questões Controvertidas da Lei 10.303, de 31.10.2001. Rio de Janeiro: Forense, 2002, p. 389)

245 CEREZETTI, Sheila Christina Neder. Administradores Independentes e Independência dos Administradores. Regras Societárias Fundamentais ao Estímulo do Mercado de Capitais Brasileiro. In VON ADAMEK, Marcelo Vieira (Coord.). In Temas de Direito Societário e Empresarial Contemporâneos. Liber Amicorum Prof. Dr. Erasmo Valladão Azevedo e Novaes França. São Paulo: Malheiros, 2011, p. 589.

${ }^{246}$ VERÇOSA, Haroldo Malheiros Duclerc. Curso de direito comercial. v. 3. $2^{\mathrm{a}}$ ed. São Paulo: Malheiros, 2011, p. 523. Também nesse sentido, a opinião de SZTAJN: "A base para buscar essa independência dos conselheiros é afastar eventuais conflitos de interesse entre os acionistas eleitores, que não devem supor estarem diretamente representados pelos indicados/eleitos que defenderão interesses pessoais, e os interesses da sociedade, que são os que devem prevalecer. Por isso é que não só os acionistas, shareholders, mas todos
} 
BOCATER e CAMARGO afirmam que a independência da administração representa um benefício em qualquer forma de estrutura de propriedade acionária:

Quer estejamos diante de uma situação do controle concentrado, quer diante de uma situação de controle compartilhado, em se tratando de companhias abertas, nas quais existe a possibilidade de se prejudicarem os interesses dos investidores, que compram, de boa-fé, ações no mercado, dever-se-ia sempre almejar a preservação de uma esfera de poder de administração independente, pois assim se permite que o interesse da companhia, e consequentemente de todos os acionistas, seja sempre colocado em primeiro plano. Essa constitui, a nosso ver, uma regra básica das boas práticas da governança corporativa, que devemos ter em mente para que os bons propósitos que inspiraram o legislador da Lei $10.303 / 01$ possam ser implementados. ${ }^{247}$

\title{
5.3.2. As boas práticas de governança corporativa, os conselheiros
} independentes e o papel da autorregulação

\author{
Não é de hoje que ouvimos sobre as famosas práticas de "corporate \\ governance ${ }^{\text {248 }}$, por nós traduzida ${ }^{249}$ como "governança corporativa".
}

Ainda que antigas ${ }^{250}$, tais práticas desenvolveram-se de maneira mais pujante nos Estados Unidos, depois dos escândalos contábeis praticados na Enron e Worldcom ${ }^{251}$. De

\footnotetext{
e quaisquer stakeholders, devem ter seus interesses respeitados pelos membros dos colegiados." (SZTAJN, Rachel. Acordo de Acionistas. In SADDI, Jairo (Org.). Fusões e Aquisições: Aspectos Jurídicos e Econômicos. São Paulo: IOB, 2002, p. 289)

247 CAMARGO, João Laudo; BOCATER, Maria Isabel do Prado. Conselho de Administração: seu Funcionamento e Participação de Membros Indicados por Acionistas Minoritários e Preferencialistas. In LOBO, Jorge (Coord.). Reforma da Lei das Sociedades Anônimas - Inovações e Questões Controvertidas da Lei 10.303, de 31.10.2001. Rio de Janeiro: Forense, 2002, p. 395. Também nesse sentido, CALIXTO SALOMÃO: "Outra característica comum da companhia, decorrente de sua natureza empresária e da necessidade de profissionalizar a sociedade, está na independência da administração. (...) esta característica está presente em sistemas formalmente muito díspares (como EUA e Alemanha) e é característica essencial para o funcionamento eficiente de qualquer empresa." (SALOMÃO FILHO, Calixto. O Novo Direito Societário. $4^{\text {a }}$ ed. São Paulo: Malheiros, 2011, p. 92)

${ }^{248}$ Nesse sentido, o comentário de VERGUEIRO:"O que existe de 'novo' sobre o tema [da governança corporativa] é a identificação de alguns períodos na história do Direito Comercial dos países, nos quais ocorreu um apogeu sobre as discussões envolvendo as regras do jogo relativas aos métodos de gestão e supervisão societárias. (...) Nos dias de hoje, discute-se como o processo de formação da vontade social deve ser elaborado para que o máximo de riqueza possível seja produzido pela sociedade, de que maneira os interesses pessoais dos controladores podem atrapalhar essa criação de riqueza e se é estratégico ou não dar maior participação a outros - que não acionistas - dentro do processo de formação da vontade social." (VERGUEIRO, Carlos Eduardo. Acordo de Acionistas e a Governança das Companhias. São Paulo: Quartier Latin, 2010, p. 39)

${ }^{249}$ Muitos autores criticam a tradução da expressão "corporate governance". VERGUEIRO, por exemplo, sugere o uso do termo "governança societária".
} 
forma geral, naquele país as práticas de boa governança corporativa têm por objetivo precípuo a ampla divulgação de informações (full disclosure $)^{252}$ e a redução dos conflitos de agência entre acionistas e administradores ${ }^{253}$.

Entre os institutos trazidos pela "corporate governance", destacamos aquele que mais interessa ao escopo deste trabalho, os conselheiros independentes.

Nos Estados Unidos (e, basicamente, na Inglaterra, já que são os únicos mercados dispersos desenvolvidos no mundo, atualmente de destaque), a posição do conselheiro independente $^{254}$ foi pensada para monitorar ${ }^{255}$ a atuação dos demais administradores ${ }^{256}$,

250 "Corporate governance is a modern term for an issue which is as old as the emergence of the large public company". (GOWER, Laurence C; DAVIES, Paul. L. Gower and Davies. The principles of modern company law. London: Sweet \& Maxwell, 1992, p. 66)

251 "As críticas ao regime das macroempresas controladas pelos administradores, especialmente sob o aspecto da insuficiência de mecanismos de controle de executivos, generalizaram-se e aumentaram de intensidade a partir da divulgação, após a quebra da Enron, no ano 2000, dos abusos cometidos em muitas companhias norte-americanas, e algumas europeias, em termos de fraudes em demonstrações financeiras, com suposta conivência de empresas de auditoria; empréstimos de interesse de executivos, e nível da remuneração paga aos executivos, inclusive sob a forma de opções de compra de ações. Esses acontecimentos, que levaram à falência da Enron e de outras companhias, bem como à dissolução da empresa de auditoria Arthur Andersen, deram origem a inquéritos administrativos, ações judiciais de indenização; processos criminais contra administradores e auditores; à votação (...) da lei designada Sarbanes-Oxley e à intensificação dos esforços para a uniformização internacional dos princípios e normas contábeis." (BULHÕES PEDREIRA, José Luiz; LAMY FILHO, Alfredo (Coord.). In Direito das Companhias. v. I. Rio de Janeiro: Forense, 2010, p. 789)

252 "O princípio do disclosure baseia-se na presunção de que uma vez adequadamente provido das informações relevantes sobre a companhia e sobre os títulos emitidos, o investidor tem condições de avaliar o mérito do empreendimento e a qualidade dos papéis." (EIZIRIK, Nelson; GAAL, Ariádna B.; PARENTE, Flávia; HENRIQUES, Marcus de Freitas. Mercado de Capitais. Regime Jurídico. $3^{\mathrm{a}}$ ed. rev. e ampl. Rio de Janeiro: Renovar, 2011, p. 485)

253 "Em tempos mais recentes, os deveres dos administradores novamente se tornaram assunto do momento (...), sinalizando a necessidade de adotar procedimentos de boa gestão societária tendentes a garantir que os administradores atuem realmente no interesse dos sócios e, atualmente, sopesem os interesses de colaboradores da empresa (stakeholders), em especial os trabalhadores. Preconiza-se, por esse movimento (...), o reforço dos deveres fiduciários (...) e das medidas de transparência (disclosure); o aperfeiçoamento dos sistemas de informações sobre a gestão social (accountability) e dos mecanismos de fiscalização e controle (sobretudo com a presença de conselheiros independentes, sem funções executivas); a melhor divisão de poderes e atribuições dos órgãos, visando preservar a independência de cada qual; e a implementação de várias medidas tendentes a devolver à assembleia geral o papel central que tradicionalmente sempre lhe reconheceu". (VON ADAMEK, Marcelo Vieira. Responsabilidade dos Administradores de S.A. e as Ações Correlatas. São Paulo: Saraiva, 2009, p. 116)

254 "Segundo William T. Allen e Reinier Kraakman, o entendimento da necessidade de existência de conselheiros independentes surgiu no começo do século $\mathrm{XX}$, quando os tribunais manifestaram o entendimento de que um contrato entre um conselheiro e a companhia seria válido se (1) considerado como justo e (2) aprovado por uma maioria de outros conselheiros, que não tivessem interesse no negócio". (VERGUEIRO, Carlos Eduardo. Acordo de Acionistas e a Governança das Companhias. São Paulo: Quartier Latin, 2010, p. 178)

${ }^{255}$ Segundo URTIAGA e SAEZ, a adoção de conselheiros independentes, na última década do século XX, foi vista pelo mercado (baseada na doutrina mais especializada) como a maneira mais eficiente (em substituição ao takeover e ao proxy fight) de monitorar os demais administradores das companhias e, assim, mitigar o problema de agência (agency problem). Uma vez monitorados pelos independentes, os demais membros da administração tenderiam a atuar mais no interesse dos acionistas e da companhia do que nos seus próprios. 
especialmente os presidentes (“CEOs”), haja vista a ampla discricionariedade que possuem e o absenteísmo da classe dispersa de acionistas.

Recentemente, a regulação norte-americana tem adotado outras maneiras de controlar os conflitos de agência, indicando que apenas os conselheiros independentes não foram suficientes para resolver o problema. É o que nos ensina MunHOZ:

(...) a presença cada vez mais relevante de investidores institucionais, especialmente fundos de pensão, hedge funds e fundos de private equity também nos Estados Unidos (...) tem fortalecido a defesa do aumento dos direitos dos acionistas em face daqueles exercidos pelos administradores. Um dos fatores mais relevantes da defesa dessa abordagem é o fato de que os administradores não possuem a posição de neutralidade e independência (...), mas, pelo contrário, têm seus interesses pessoais bem determinados (aumento de remuneração, manutenção de seus cargos, aumento do tamanho da empresa). (...) A presença de blocos de acionistas com postura ativista seria importante, portanto, para reduzir os custos de agência e a ineficiência dos administradores. ${ }^{257}$

Assim, nos Estados Unidos, a combinação de administradores independentes e acionistas mais ativos representa, atualmente, a maneira mais eficiente de regular a atividade empresarial e reduzir os custos de agência.

Aqui no Brasil, na década de 1990, o mercado identificou nas melhores práticas de governança corporativa uma oportunidade de incentivar o desenvolvimento do mercado de capitais $^{258}$. Em 1995, foi fundado o IBGC, principal referência do Brasil no assunto ${ }^{259}$, e,

(URTIAGA, María Gutierrez; SAEZ, Maribel. Deconstructing Independent Directors. Working Paper No. 186/2012. January 2012, p. 10. Disponível em <http://ssrn.com/abstract=1986842>. Último acesso em 18.01.2014).

${ }^{256}$ Nos Estados Unidos, “(...) o recurso aos administradores independentes apresentou-se, então, como uma das medidas utilizadas para proteger acionistas dos prejuízos decorrentes de a companhia ser conduzida em prol dos interesses dos seus próprios gerentes, sob a crença de que os conselheiros assim denominados estariam capacitados a cumprir sem conflito as funções a eles atribuídas." (CEREZETTI, Sheila Christina Neder. Administradores Independentes e Independência dos Administradores. Regras Societárias Fundamentais ao Estímulo do Mercado de Capitais Brasileiro. In VON ADAMEK, Marcelo Vieira (Coord.). In Temas de Direito Societário e Empresarial Contemporâneos. Liber Amicorum Prof. Dr. Erasmo Valladão Azevedo e Novaes França. São Paulo: Malheiros, 2011, p. 582)

257 MUNHOZ, Eduardo Secchi. Quem deve comandar a companhia? Alocação do poder empresarial: sistema de freios e contrapesos. In Estudos em Homenagem a Modesto Carvalhosa. São Paulo: Saraiva, 2012, pp. 513-515.

${ }^{258}$ Interessante o comentário de VERGUEIRO, citando AKERLOF: "A vontade de não ficar à margem da internacionalização de mercados e de investimentos, além do desejo de se diferenciar, parecem ser as melhores respostas (...) ao movimento das companhias, bancos de investimento e bolsa de valores a 
em 2004, foi inaugurado o segmento especial de listagem da BM\&FBovespa (então “Bovespa"), Novo Mercado ${ }^{260}$.

\section{Independentemente das fortes oscilações sofridas pelo mercado (especialmente}

após a crise mundial de 2008 e o momento vivido atualmente), desde o Novo Mercado, é

um fato que, de lá para cá, experimentamos um desenvolvimento do mercado de capitais nunca antes visto no Brasil.

perseguirem um caminho de efetiva mudança. O exemplo do mercado de carros usados, descrito por George A. Akerlof, traz subsídios para a resposta da questão, ilustrando os riscos que surgirão para as 'boas' companhias, assim entendidas aquelas que procuram valorizar o acionista, se tiverem de conviver com companhias 'ruins' em um ambiente de assimetria informacional. (...) O que Akerlof quer dizer (...) é que existem mercados nos quais a oferta de produtos com qualidade superior à média traz como resultado não um lucro adicional para o vendedor, que conseguirá vender seus produtos pelo preço médio do mercado, mas apenas a contribuição para que a própria 'média' (de qualidade, não preço) seja elevada." (VERGUEIRO, Carlos Eduardo. Acordo de Acionistas e a Governança das Companhias. São Paulo: Quartier Latin, 2010, pp. 113-114)

${ }^{259}$ (i) O instituto assim define o conceito de boas práticas de governança corporativa: "sistema pelo qual as organizações são dirigidas, monitoradas e incentivadas, envolvendo os relacionamentos entre proprietários, Conselho de Administração, Diretoria e órgãos de controle. As boas práticas de Governanca Corporativa convertem princípios em recomendações objetivas, alinhando interesses com a finalidade de preservar e otimizar o valor da organização, facilitando seu acesso a recursos e contribuindo para sua longevidade." (Instituto Brasileiro de Governança Corporativa. Código de Melhores Práticas de Governança Corporativa. $4^{a}$ ed. São Paulo: IBGC, 2009); e (ii) LOBO conceitua governança corporativa como "o conjunto de normas, consuetudinárias e escritas, de cunho jurídico e ético, que regulam os deveres de cuidado, diligência, lealdade, informação e não intervir em qualquer operação em que tiver interesse conflitante com o da sociedade; o exercício das funções, atribuições e poderes dos membros do conselho de administração, da diretoria executiva, do conselho fiscal e dos auditores externos e o relacionamento entre si e com a própria sociedade, seus acionistas e o mercado em geral" (LOBO, Jorge. Princípios de governança corporativa. In Revista de Direito Mercantil, Industrial, Econômico e Financeiro. no 142. São Paulo: Malheiros, pp. 141-154) 260 (i) Segundo CALIXTO SALOMÃO: "A proposta do Novo Mercado repousa sobre três bases principais. A primeira base sem dúvida é a informação completa. Os requisitos de informação previstos no regulamento vão muito além dos previstos na lei societária. A segunda viga de sustentação é o reforço das garantias patrimoniais dos minoritários no momento de saída da sociedade. É só na terceira linha de sustentação que se nota algo de verdadeiramente original. Trata-se das chamadas proteções estruturais, por modificar a própria conformação interna das sociedades. Não são diretamente inspirados pelo princípio cooperativo, mas sem dúvida ajudam a persegui-lo ao enfraquecer ou permitir o enfraquecimento do poder do controlador." (SALOMÃO FILHO, Calixto. O Novo Direito Societário. $4^{\text {a }}$ ed. São Paulo: Malheiros, 2011, pp. 69-70); e (ii) Destacamos, ainda, o seguinte comentário visionário de CALIXTO SALOMÃo, feito antes da quebra das empresas do grupo do empresário Eike Batista: "A concentração em torno do screening [técnica de promoção das qualidades de uma determinada cia sobre a outra] sobre práticas éticas é fundamental, mas não deve obscurecer a necessidade de que só empresas com um mínimo de solidez adentrem ao mercado. Permitir em períodos de crescimento econômico que novas empresas com projetos economicamente duvidosos adentrem indiscriminadamente no Novo Mercado, por melhores que sejam as práticas de governança, pode criar bolhas especulativas semelhantes às que ocorreram em países que criaram segmentos diferenciados com base exclusivamente na especificidade econômica da atividade (como foi o setor de novas tecnologias na Nasdaq norte-americana (...)). (...) da mesma maneira que se criticou o fato de a exclusiva preocupação com os resultados criar uma seleção adversa em matéria de práticas de governança, a preocupação exclusiva com governança pode criar uma seleção adversa em relação ao desempenho econômico. Ambos os resultados extremos são inconvenientes." (SALOMÃO FILHO, Calixto. O Novo Direito Societário. $4^{\mathrm{a}}$ ed. São Paulo: Malheiros, 2011, p. 71) 
O IBGC segue um caminho mais brando, mas não menos importante, já que oferece apenas recomendações ao mercado. O Novo Mercado, por sua vez, foi pensado como um segmento especial de listagem formado somente por companhias praticantes de níveis mínimos de boa governança corporativa ${ }^{261}$. Entre as principais inovações trazidas, estão a proibição de emissão de ações preferenciais, o tratamento igualitário a todos os acionistas na oferta pública de aquisição de controle, a arbitragem como meio de solução de conflitos, o número mínimo de ações em circulação (free-float - 25\%), a proibição de cumulação dos cargos de presidente do conselho e diretor presidente, bem como um número mínimo de conselheiros independentes $(20 \%)^{262}$.

O Novo Mercado é uma experiência muito bem sucedida de autorregulação, fonte de elogios de, e inspiração a, outros países, inclusive ${ }^{263}$. Com ele a BM\&FBovespa encurtou o caminho da via legislativa e ofereceu um produto de qualidade global aos interessados em atrair investidores mais exigentes ${ }^{264}$.

261 “(...) as regras do Novo Mercado possuem um papel importante na redução de benefícios privados do controle." (OIOLI, Erik Frederico; VEIGA, Marcelo Godke. Convergência e divergência em sistemas de mercados de capitais: $O$ caso brasileiro. In CASTRO, Rodrigo R. Monteiro de; MOURA AZEVEDO, Luis André N. (Coord.). Poder de Controle e Outros Temas de Direito Societário e Mercado de Capitais. São Paulo: Quartier Latin, 2010, p. 341) Os autores citam pelo menos três modificações positivas trazidas pelo Novo Mercado que ajudaram a diminuir a extração de benefícios privados pelo controlador, (i) a proibição de emissão de ações preferenciais, tornando mais cara a manutenção do controle majoritário; (ii) eliminação do prêmio de $20 \%$ ao controlador, em caso de oferta pública por transferência de controle; e (iii) exigência de $20 \%$ de conselheiros independentes (desvinculados do controlador).

${ }^{262}$ Em revisão recente do Regulamento, a BM\&FBovespa propôs o aumento desste percentual para $30 \%$, porém não obteve aprovação do número de membros necessários para aprovar a mudança. CEREZETTI afirma que é “(i)mportante referir, igualmente, que a própria doutrina, que aclama os benefícios da obrigatoriedade de administradores independentes, não defende que essa característica seja imposta a todos os membros, argumentando-se que isso acarretaria a falta de conhecimento específico de que são dotados muitos dos gerentes não independentes." (CEREZETTI, Sheila Christina Neder. Administradores Independentes e Independência dos Administradores. Regras Societárias Fundamentais ao Estímulo do Mercado de Capitais Brasileiro. In VON ADAMEK, Marcelo Vieira (Coord.). In Temas de Direito Societário e Empresarial Contemporâneos. Liber Amicorum Prof. Dr. Erasmo Valladão Azevedo e Novaes França. São Paulo: Malheiros, 2011, p. 587)

${ }^{263}$ Transcrevemos, a seguir, a opinião de HANSMANN e KRAAKMAN sobre o Novo Mercado: “(...) avoided the mistakes of its German predecessor and has been a stunning success, effectively breaking a century-old blockage of corporate reform and facilitating the rapid development of new and growing firms." Acrescentam os autores: the Novo Mercado has added to the old regime, comprised of lightly regulated and often opportunistic controlled companies, a new generation of firms with a more dispersed ownership structure and a much stronger commitment, both ideological and factual, to the SSM [shareholders' oriented model]." (HANSMANN, Henry e KRAAKMAN, Reinier. Reflections on the end of history for corporate law. August 2011. Forthcoming in Abdul Rasheed and Toru Yoshikawa, Eds. Convergence Corporate Governance: Promise and Prospects. Palgrave-MacMillan 2012, p. 10-11. Disponível em $<$ http://ssrn.com/abstract=2095419> Último acesso em 18.01.2014).

${ }^{264}$ GILSON afirma que convergência funcional tende a ser a primeira resposta à pressão competitiva, já que a modificação formal é mais custosa. O caminho ou a solução é encontrada dentro das características de cada sistema analisado, dentro de seus limites, cultura, legislação e costume. (GILSON, R. Globalizing corporate governance: convergence of form or function. American Journal of Comparative Law 49, 2001, pp. 342) 
A fórmula deu tão certo que a BM\&Bovespa criou segmentos de listagem intermediários (Bovespa Mais e Níveis 1 e 2) e, recentemente, em conjunto com o IBGC e as principais entidades participantes do mercado de capitais ${ }^{265}$, criou o CAF (inspirado no Takeover Panel inglês e australiano), destinado a analisar e chancelar operações de reorganização societária envolvendo companhias abertas que voluntariamente solicitarem seus serviços.

Tanto o Código de Melhores Práticas de Governança Corporativa do IBGC ${ }^{266}$, quanto o Regulamento do Novo $\operatorname{Mercado}^{267}$ definem o conceito de conselheiro independente $^{268}$. As definições são bem próximas, exceto pelo fato de a do IBGC exigir alguns poucos critérios a mais, tais como não vinculação a acordo de acionistas. ${ }^{265}$ Associação de Investidores no Mercado de Capitais (AMEC), Associação das Entidades dos Mercados
Financeiro e de Capitais (ANBIMA).
266 "Não ter qualquer vínculo com a organização, exceto participação não relevante no capital; Não ser sócio
controlador, membro do grupo de controle ou de outro grupo com participação relevante, cônjuge ou parente
até segundo grau destes, ou ligado a organizações relacionadas ao sócio controlador; Não estar vinculado por
acordo de acionistas; Não ter sido empregado ou diretor da organização (ou de suas subsidiárias) há pelo
menos, 3 (três) anos; Não ser ou ter sido, há menos de 3 (três) anos, conselheiro de organização controlada;
Não estar fornecendo, comprando ou oferecendo (negociando), direta ou indiretamente, serviços e/ou
produtos à organização em escala relevante para o conselheiro ou a organização; Não ser cônjuge ou parente
até segundo grau de algum diretor ou gerente da organização; Não receber outra remuneração da
organização, além dos honorários de conselheiro (dividendos oriundos de participação não relevante no
capital estão excluídos desta restrição); Não ter sido sócio, nos últimos 3 (três) anos, de firma de auditoria
que audite ou tenha auditado a organização neste mesmo período; Não ser membro de entidade sem-fins
lucrativos que receba recursos financeiros significativos da organização ou de suas partes relacionadas;
Manter-se independente em relação ao CEO; Não depender financeiramente da remuneração da
organização". (destaques nossos) (Instituto Brasileiro de Governança Corporativa. Código de Melhores
Práticas de Governança Corporativa. $4^{a}$ ed. São Paulo: IBGC, 2009, item 2.16, p. 37)

${ }^{267}$ A BM\&FBovespa assim definiu o termo "conselheiro independente", no Regulamento do Novo Mercado, o qual foi posteriormente adotado pela CVM, no Parecer de Orientação 35, de 2008: "caracteriza-se por: (i) não ter qualquer vínculo com a companhia, exceto participação de capital; (ii) não ser acionista controlador, cônjuge ou parente até segundo grau daquele, ou não ser ou não ter sido, nos últimos 3 (três) anos, vinculado a sociedade ou entidade relacionada ao acionista controlador (pessoas vinculadas a instituições públicas de ensino e/ou pesquisa estão excluídas desta restrição); (iii) não ter sido, nos últimos 3 (três) anos, empregado ou diretor da companhia, do acionista controlador ou de sociedade controlada pela companhia; (iv) não ser fornecedor ou comprador, direto ou indireto, de serviços e/ou produtos da companhia em magnitude que implique perda de independência; (v) não ser funcionário ou administrador e sociedade ou entidade que esteja oferecendo ou demandando serviços e/ou produtos à companhia; (vi) não ser cônjuge ou parente até segundo grau de algum administrador da companhia; (vii) não receber outra remuneração da companhia além da de conselheiro (proventos em dinheiro oriundos de participação no capital estão excluídos desta restrição)".

${ }^{268}$ CerezZeti e Vergueiro nos ajudam a comparar nosso conceito de conselheiro independente com o adotado nos Estados Unidos. Pela leitura, podemos claramente identificar a semelhança e provável inspiração: (i) "Nos Estados Unidos, o Listed Company Manual, da NYSE, e as NASDAQ Listing Rules, por exemplo, demandam que o conselho das companhias listadas seja composto por uma maioria de administradores independentes. A qualificação depende da declaração, feita pelo conselho, de que o membro não tem relação relevante com a companhia, seja diretamente com o sócio ou administrador de uma organização que se relacione com a sociedade." (CEREZETTI, Sheila Christina Neder. Administradores Independentes e Independência dos Administradores. Regras Societárias Fundamentais ao Estímulo do Mercado de Capitais Brasileiro. In VON ADAMEK, Marcelo Vieira (Coord.). In Temas de Direito 
O fato é que o Novo Mercado define o conceito de conselheiro independente, mas para por aí. Não atribui ao conselheiro independente funções distintas das dos demais conselheiros, não exige um prazo máximo para sua permanência no cargo, tampouco garante qualquer tipo de tratamento diferenciado à sua destituição.

Conforme alertamos no Capítulo II, quando do estudo das estruturas de capital da companhia, apontamos que mercados concentrados, como o nosso, estão sujeitos a um distinto conflito de agência, i.e., aquele verificado entre acionistas majoritários $\mathrm{e}$ minoritários $^{269}$.

Nas companhias com capital concentrado, os conselheiros independentes não são necessários para monitorar os demais administradores, já que todos eles (incluindo o próprio conselheiro independente) o são pelo acionista controlador. Esse fator representa, inclusive, uma das vantagens dos mercados concentrados em relação aos dispersos, qual

Societário e Empresarial Contemporâneos. Liber Amicorum Prof. Dr. Erasmo Valladão Azevedo e Novaes França. São Paulo: Malheiros, 2011, p. 579); e (ii) Na New York Stock Exchange, o conselho de administração deve ser majoritariamente composto por conselheiros independentes, assim considerados: (a) as pessoas que não tenham tido relações materiais com a companhia, ou tenham sido sócias ou administradoras de uma entidade que tenha tido relações com a companhia; tenham sido ou sejam parentes de alguém que tenha sido empregada da companhia nos últimos três anos; (b) adicionalmente, um conselheiro não será considerado como independente se: (i) o conselheiro é ou foi nos últimos três anos empregado da companhia listada, ou algum membro da sua família é ou foi empregado nos últimos três anos como executivo da companhia listada; (ii) o conselheiro tenha recebido, ou tenha algum membro da sua família que tenha recebido, durante qualquer período de doze meses nos últimos três anos, mais de cem mil dólares na forma de remuneração direta da companhia listada, valor esse diferente da remuneração própria de membro do conselho e de comitês, dos valores recebidos para previdência complementar, por serviços passados (desde que a remuneração não se relacione a serviços continuados); (iii) (A) o conselheiro ou algum membro da sua família é sócio de sociedade encarregada de fazer a auditoria interna ou externa da companhia; (B) o conselheiro é empregado dessa sociedade que faz auditoria; (C) o conselheiro possui algum membro de sua família que seja empregado dessa sociedade que faz a auditoria e participa nos trabalhos da auditoria e cumprimento de obrigações fiscais, não incluindo planejamento fiscal; ou (D) o conselheiro ou algum membro de sua família foi, nos últimos três anos, e deixou de ser, sócio ou empregado dessa sociedade e trabalhou pessoalmente na auditoria da companhia listada nesse período, (iv) o conselheiro ou algum membro da sua família é ou foi nos últimos três anos empregado como executivo de outra sociedade onde qualquer dos atuais administradores trabalharam no comitê de remuneração; (v) o conselheiro é empregado, ou algum membro da sua família é diretor, de uma sociedade que tenha feito ou recebido pagamentos da companhia listada decorrentes de propriedade ou serviços em valores que, em qualquer dos três últimos exercícios fiscais, exceda um milhão de dólares ou $2 \%$ das receitas consolidadas dessa sociedade." (íntegra do item 303A2, apud, VERGUEIRO, Carlos Eduardo. Acordo de Acionistas e a Governança das Companhias. São Paulo: Quartier Latin, 2010, pp. 183-184)

${ }^{269}$ Vide a seguinte transcrição do texto de URTIAGA e SAEZ: “(...) the board of directors lack mandate, the incentives and the ability to control insiders, and (...) this problem is especially acute in jurisdictions where the main agency problem arises between controlling and minority shareholders." (URTIAGA, María Gutierrez; SAEZ, Maribel. Deconstructing Independent Directors. Working Paper No. 186/2012. January 2012, p. 4. Disponível em <http://ssrn.com/abstract=1986842>. Último acesso em 18.01.2014). 
seja, menor custo de monitoramento dos administradores, dado o alto investimento financeiro do controlador que tende a acompanhar a atividade empreasarial de perto.

O problema de agência, nesse cenário de concentração, como dito em outras oportunidades, é deslocado para o conflito entre controlador e minoritários ${ }^{270}$.

Tendo em vista o fato de o acionista controlador não poder ser dispensado ou substituído, pelo contrário, ele ter força inclusive de retirar o conselheiro independente ${ }^{271}$, é preciso repensar essa função. Não há dúvidas sobre sua importância, mas seu bom exercício passa pela revisão do modelo orgânico, já que é preciso criar condições para que o administrador independente exerça corretamente sua função, qual seja, a de monitorar a expropriação de benefícios privados pelo controlador ${ }^{272}$.

A rotineira prática de importação de conceitos e institutos de direito norteamericano precisa ser cuidadosamente avaliada e adaptada à nossa realidade e aos nossos $\operatorname{conflitos}^{273}$. A nosso ver, esse é o problema da definição de conselheiro independente do Novo Mercado. Trata-se, atualmente, de um instituto inócuo, que poderia contribuir muito mais para o desenvolvimento do mercado de capitais.

\footnotetext{
${ }^{270}$ Sobre os conselheiros independentes, URTIAGA e SAEZ ensinam com distinção que: “(...) their goal here from a regulatory point of view is not to improve the decision making system of the corporation through monitoring, but to police the expropriation risk of these corporations." (URTIAGA, María Gutierrez; SAEZ, Maribel. Deconstructing Independent Directors. Working Paper No. 186/2012. January 2012, p. 13. Disponível em <http://ssrn.com/abstract=1986842>. Último acesso em 18.01.2014)

${ }^{271}$ Vide o comentário de VERÇOSA nesse sentido: “(...) Aliás, falar em 'conselheiros independentes' é uma inverdade, pois qualquer deles sempre poderá ser demitido pelo controlador sem qualquer justificativa (...)”. (VERÇOSA, Haroldo Malheiros Duclerc. Curso de direito comercial. v. 3. $2^{\mathrm{a}}$ ed. São Paulo: Malheiros, 2011, p 434)

${ }^{272}$ Na realidade brasileira, o cenário é ainda mais agravado, já que a lei legitimou a vinculação do administrador ao controlador, praticamente impossibilitando que o administrador monitore eventual extração de benefícios privados do controle por parte do controlador. CARVALHOSA tece comentário nesse sentido: "No direito societário brasileiro, por força do art. 118 da Lei n. 6.404/76, em sua redação dada pela Lei n. 10.303/201, estabelece-se uma hegemonia absoluta dos controladores sobre o Conselho de Administração e a diretoria da sociedade. Essa hegemonia dos controladores sobre os administradores decorrente dos acordos de voto em bloco demonstra a falácia dos princípios de governança corporativa que os promotores da Lei $\mathrm{n}$. 10.303, de 2001, propalaram como o motivo fundamental da alteração da lei societária." (CARVALHOSA, Modesto. Comentários à lei das sociedades anônimas. v. 2. $5^{\text {a }}$ ed. São Paulo: Saraiva, 2011, p. 15)

${ }^{273}$ Para URTIAGA e SAEZ, toda a construção científica sobre utilidade e conveniência do uso de conselheiros independentes foi baseada na experiência e problemas dos países de estrutura de capital disperso (Estados Unidos e Reino Unido). Na realidade de capital concentrado, a adoção de conselheiros independentes pode até agravar o conflito entre maioria e minoria. Isso porque, ao adotar tal prática, regulador e minorias acreditam que o problema estaria resolvido, deixando, portanto, de refletir sobre alternativas de monitoramento do acionista controlador (expropriador). (URTIAGA, María Gutierrez; SAEZ, Maribel. Deconstructing Independent Directors. Working Paper No. 186/2012. January 2012, p. 13. Disponível em $<$ http://ssrn.com/abstract=1986842>. Último acesso em 18.01.2014)
} 
Se, no Brasil, temos tanto a atribuição de deveres fiduciários aos acionistas controladores, quanto claras hipóteses de abuso de maioria, parece-nos que nossa lei é boa. Falta-lhe, apenas, meios efetivos de aplicar suas disposições, bem como repensar e utilizar o instituto dos conselheiros independentes como um complemento, um agente adicional capaz de monitorar as atividades do controlador e, no fim do dia, verificar se ele está cumprindo os deveres atribuídos pela "boa" lei.

O caminho pensado pelas autoras URTIAGA e SAEZ passaria pelo fato de os conselheiros independentes serem vistos não como um representante do acionista, mas do próprio Estado, em fiscalizar o cumprimento à lei societária e denunciar eventual decumprimento, para que o Estado garanta a aplicação da lei.

Assim, propomos um conselheiro independente definido, tal qual hoje em dia pelo Novo Mercado, mas dotado das seguintes diferenças: (i) tempo máximo de permanência na função (e.g., 3 anos); (ii) elevação do percentual mínimo atual de conselheiros independentes; (iii) designação de uma função específica de monitoramento da extração de benefícios privados do controle pelo acionista controlador ${ }^{274}$, sendo-lhe expressamente facultado denunciar à CVM atitudes suspeitas passíveis de investigação; (iv) impossibilidade expressa de sua vinculação a acordo de acionistas; (v) impedimento de o acionista controlador votar na sua eventual destituição proposta em assembleia, i.e., a decisão caberia aos demais acionistas; e (vi) designação de determinadas matérias (especialmente operações e reorganizações entre partes relacionadas) que exigiriam aprovação de um número mínimo de conselheiros independentes.

\footnotetext{
${ }^{274}$ A nosso ver, o CAF exercerá um papel fundamental de monitoramento da extração de benefícios privados de controle. As operações de reorganizações societárias constituem importante foco de desvio de recursos da companhia e dos minoritários. Assim, ainda que a submissão de tais operações seja voluntária, o incentivo reputacional de receber a chancela do órgão deverá fazer com que muitos controladores votem pela adesão ao CAF e, consequentemente, comportem-se adequadamente na condução de tais operações. É o que vimos no Novo Mercado e esperamos ver novamente. Saudamos a BM\&FBovespa, mais uma vez, pela brilhante iniciativa.
} 


\section{VINCULAÇÃO DA ADMINISTRAÇÃO AO ACORDO DE ACIONISTAS. POSIÇÕES DOUTRINÁRIAS E AUTORREGULAÇÃO}

Depois de analisarmos o conceito de interesse social, que, a nosso ver, deve ser interpretado sob a ótica institucionalista, e do extenso estudo de cada uma das fontes de poder da sociedade anônima, podemos, enfim, mencionar aqueles que, em nosso conhecimento, já se manifestaram sobre a possibilidade de vincular administradores a acordo de acionistas.

Ainda antes de adentrar no tema em si, vale esclarecer que, independentemente da posição que se assuma sobre um poder ser vinculado por outro, a nosso ver, a LSA andou muito bem em, como visto nos capítulos anteriores, atribuir tanto aos acionistas quanto aos administradores o dever de observar o interesse da companhia ${ }^{275}$. Isso ajuda a minimizar os impactos de eventuais conflitos entre tais poderes e servirá sempre de garantia aos demais acionistas, que terão, à disposição, tanto a ação por abuso de poder de controle (art. 117, da LSA), quanto a ação de responsabilidade (art. 159, da LSA), como meio de proteção ao descumprimento do interesse social ${ }^{276}$.

Com relação à vinculação de administradores, ressaltamos que há diversas posições doutrinárias a respeito do tema. Apesar de não ser tão fácil alocar as diferentes correntes, elas incluem: (i) aqueles favoráveis à vinculação dos administradores ao acordo de acionistas, de maneira (a) absoluta ou genérica (sem menção a eventuais limites), seja pela força da atual redação do art. 118, pelo fato de a vontade dos sócios ser a própria representação do interesse social e os acionistas serem soberanos para decidir sobre quaisquer assuntos sociais; ou (b) relativa, excetuando as hipóteses de infração à lei, ao estatuto e ao interesse social (i.e., a vontade dos sócios não necessariamente representaria o melhor interesse da companhia), tais como situações de abuso de poder de controle ou abuso de voto, delegação de competências privativas etc.; e (ii) aqueles contrários à

\footnotetext{
275 "Tanto no que concerne ao exercício do direito de voto pelos acionistas [art. 115], quanto no tocante à atividade dos órgãos da administração [art. 154], a Lei $\mathrm{n}^{\circ}$ 6.404/1976 tratou de registrar o respeito e a necessária vinculação aos fins e aos interesses da companhia, principais balizadores da tomada de decisões no âmbito das sociedades." (PATELLA, Laura Amaral; BORES, Leandro Vilarinho; BERNARDES, Lucas Petri; AZEVEDO, Luís André Negrelli de Moura. Deveres Fiduciários dos Administradores. Vinculação dos Administradores. In Mercado de Capitais Brasileiro: Doutrina, Cases e Materials. São Paulo: Quartier Latin, 2012, p. 227)

${ }^{276}$ Ainda que, do ponto de vista prático, esses dispositivos da LSA tenham eficácia bastante reduzida.
} 
vinculação dos administradores ao acordo de acionistas, pelo fato de, entre outras razões, os $\S \S 8^{\circ}$ e $9^{\circ}$ serem incompatíveis com o regime de governança até então previsto pela LSA, eminentemente os arts. 154 e 139.

\subsection{Vinculação genérica}

A corrente que defende a vinculação genérica entende, em suma, que o dever de independência atribuído aos administradores no art. 154 da LSA é compatível com a sua vinculação ao acordo e não chega a mencionar eventuais limites à tal submissão.

Defendem esse ponto de vista, a partir dos seguintes principais argumentos (individual ou conjuntamente considerados):

(i) o próprio acordo de acionistas deve promover o interesse social, consoante o $\S 2^{\circ}$ do art. 118 da lei societária, havendo, portanto, uma presunção de que a instrução conferida é dada no interesse da companhia. Os casos de infração do interesse social seriam objeto de responsabilização, por infração aos arts. 115 ou 116, conforme o caso; e

(ii) força e prevalência do art. 118 , caput e $\$ \S 8^{\circ}$ e $9^{\circ}$, da LSA, cumulada ou não com o argumento da soberania da assembleia geral (art. 121, da LSA). Isto é, defendem que a vinculação confere maior segurança jurídica e eficácia ao acordo de acionistas, e que o legislador de 2001 foi feliz e fiel à realidade societária brasileira ${ }^{277}$.

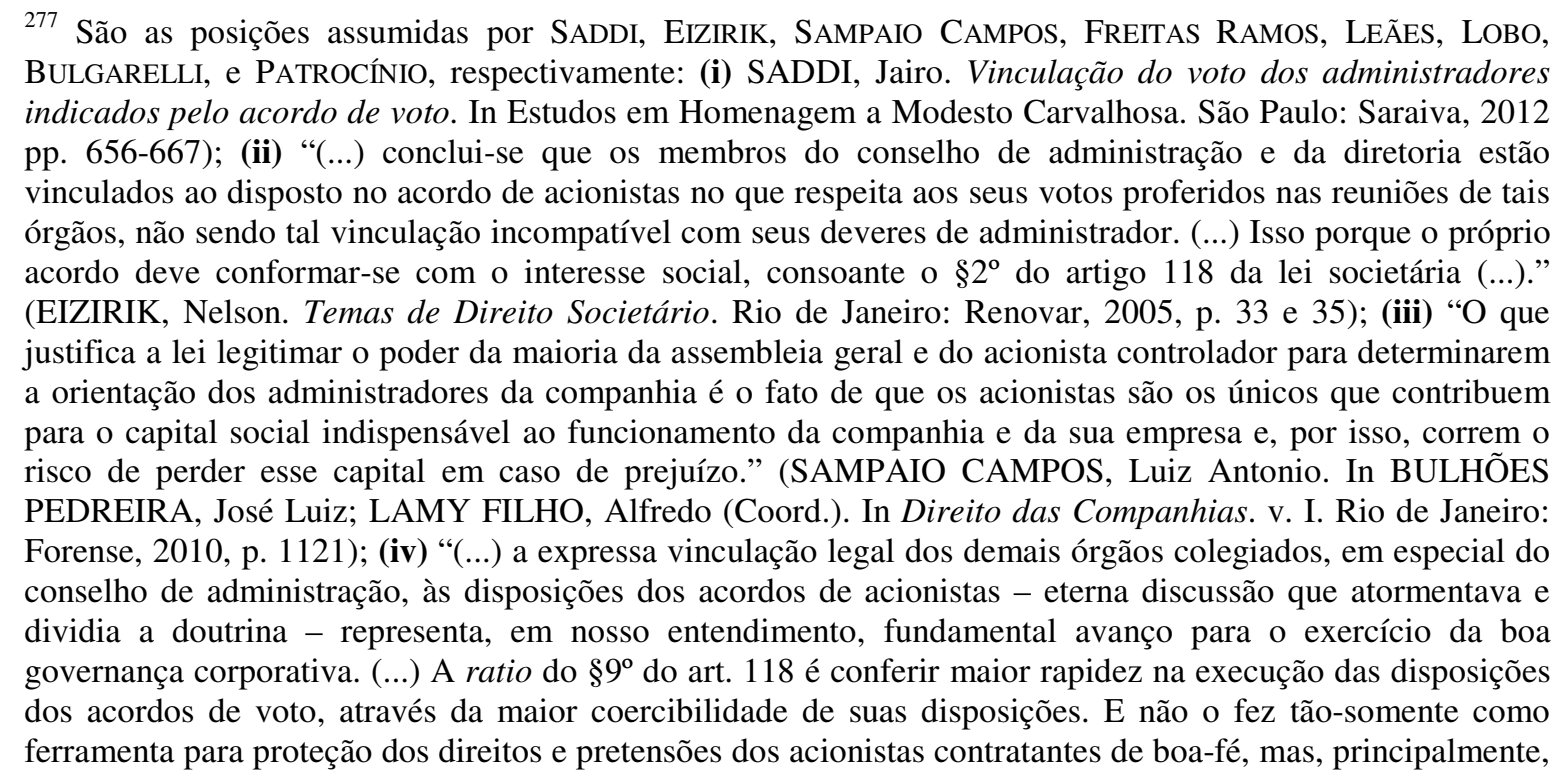




\title{
6.2. Vinculação relativa
}

\author{
Há, ainda, uma corrente predominante $e^{278}$ de doutrinadores que reconhecem a \\ vinculação de maneira relativa, i.e., permite-se a vinculação, exceto nas seguintes \\ principais hipóteses (individual ou conjuntamente consideradas):
}

para evitar danos à companhia, que por diversas vezes ficava sujeia às desavenças pessoais entre seus sócios, sofrendo, reiteradamente, consideráveis prejuízos." (FREITAS RAMOS, Felipe de. Responsabilidade dos Signatários de Acordo de voto no Regime da Lei n. 10.303/2001. In Revista de Direito Mercantil, Industrial, Econômico e Financeiro. $n^{\circ}$ 125. São Paulo: Malheiros, p. 116 e 119); (v) “(...) é por todos admitido que o conselho pode ter determinadas deliberações suas submetidas à prévia aprovação da assembleia geral, órgão soberano da companhia. Por conseguinte, não há por que não admitir, da mesma forma, a regra de que os conselheiros devem deliberar em conformidade com o que for decidido por acionistas titulares de mais de $72 \%$ do capital votante da empresa. (...) a consulta prévia aos acionistas convenentes para a eleição ou a destituição desses diretores, pactuada no acordo, não agride, sequer remotamente, essa prerrogativa, pois não interfere diretamente na eleição ou na destituição dos mesmos." (LEÃES, Luiz Gastão de Barros. Efeitos sobre terceiros dos acordos de acionistas. In Pareceres. v. II. São Paulo: Singular, 2004, p. 1.108); (vi) "(...) não há como admitir que conselheiro eleito nos termos de acordo de acionistas fique isento de votar de acordo com o que pactuaram os acionistas no acordo, sob cujos termos foi eleito. Se podem os acionistas obrigar-se a aprovar ou rejeitar uma proposta de deliberação da assembleia, - e todos os negócios da companhia podem ser objeto de compromisso de voto do acionista porque podem ser objeto de deliberação da assembleia - não é admissível que administradores eleitos nos termos do acordo de acionistas possam votar contrariamente ao pactuado pelos acionistas que os elegeram. (...) não nos parecem procedentes as distinções que se fazem em doutrina entre matérias de competência privativa e não privativa (Wald, 2001, p. 16) ou entre deliberações fiscalizatórias, administrativas e deliberatórias (Tornovsky, 2002, p. 103) (...) para excetuar algumas matérias tidas como privativas do Conselho de Administração. Em nosso entendimento, por força do artigo 121, a assembleia geral, fonte dos poderes do acionista controlador, tem poderes para deliberar sobre todos os negócios relativos ao objeto da companhia, inclusive aqueles de competência do Conselho de Administração. O artigo 139 veda que o estatuto social atribua a outro órgão essa competência e não colide nem com o artigo 121, nem com a alínea 'b' do artigo 116, que reconhece o poder do acionista controlador de dirigir as atividades sociais e orientar o funcionamento dos órgãos da administração da companhia. Se os acionistas signatários de um Acordo de Acionistas deliberam algo que se repute ilegal ou abusivo, podem incidir no artigo 115 e a deliberação pode ser anulada, se for o caso. Mas isso não autoriza o presidente da reunião a computar voto dissidente do acionista ou do administrador, pois, se assim o fizer, estará, aí sim, exercendo julgamento sobre a deliberação tomada segundo o acordo de acionistas". (LOBO, Carlos Augusto da Silveira. BULHÕES PEDREIRA, José Luiz; LAMY FILHO, Alfredo (Coord.). In Direito das Companhias. v. I. Rio de Janeiro: Forense, 2010, p. 486-488); (vii) BULGARELLI, Waldírio. Validade de disposições de acordo de acionistas de votarem em bloco, assegurando a política gerencial única e necessária. In Revista de Direito Mercantil. no . 123. São Paulo: Malheiros, p. 187; (viii) BULHÕES PEDREIRA, José Luiz. Acordo de acionistas sobre controle de grupo de sociedades. Validade de estipulação de que os membros do conselho de administração de controlada devem votar em bloco segundo orientação definida pelo grupo controlador. In Revista de Direito Bancário, do Mercado de Capitais e da Arbitragem. $\mathrm{n}^{\circ}$ 15. São Paulo: Revista dos Tribunais, p. 235; e (ix) PATROCÍNIO, Daniel Moreira do. Autotutela do Acordo de Acionistas. Novo Regime estabelecido pela Lei 10.303/2001. In Revista de Direito Mercantil. ${ }^{\circ}$ 135. São Paulo: Malheiros. pp. 194-205.

${ }^{278}$ Entendemos ser a posição dominante, em razão do grande número de juristas que se utilizam de um ou mais argumentos deste Subcapítulo 6.2, para fundamentar a vinculação relativa dos administradores a acordo de acionistas, quais sejam: Bulhões Pedreira, Lamy Filho, Verçosa, Comparato, Carvalhosa, Calixto Salomão, Valladẽo, SZTAJn, Munhoz, Wald, Bocater e CAMARgo, Tornovsky, ARAGão, Salles de Toledo, Adamek, Gorga e Gelman Abreu, Cerezetti, Denise Salles, ana Rafaela MEDEIROS e os autores da obra conjunta entitulada "Deveres Fiduciários dos Administradores. Vinculação dos Administradores", já citada neste trabalho. 
representaria o melhor interesse da companhia, tais como situação de abuso de poder de controle ou abuso de voto, conforme previstas no art. $118, \S 2^{\circ}$, LSA) ${ }^{280}$;

${ }^{279}$ São as posições de BULHÕES PEDREIRA e LAMY FILHO (em trabalho mais recente, já que, conforme visto no subcapítulo anterior, em manifestação individual, os juristas haviam defendido genericamente a vinculação), dos autores da obra coletiva entitulada "Deveres Fiduciários dos Administradores. Vinculação dos Administradores", já mencionada neste trabalho, e VERÇOSA, respectivamente: (i) "Na hipótese de conflito entre deliberação da assembleia e o preceito legal de não violar a lei ou estatuto, este há de prevalecer. É inquestionável que a assembleia geral não pode validamente dar instruções ilegais aos administradores e que estes não têm apenas a faculdade - mas o dever - de não cumprir ordens ilegais. (...) $O$ administrador conserva, evidentemente, a liberdade de agir segundo suas convicções, e se não consegue convencer os serviços jurídicos ou a maioria da assembleia da ilegalidade da ordem, deve recusar-se a cumpri-la; mas o fato de assim agir não impede que a assembleia geral exerça o poder de destituí-lo." (BULHÕES PEDREIRA, José Luiz; LAMY FILHO, Alfredo. In Direito das Companhias. v. I. Rio de Janeiro: Forense, 2010, p 807); (ii) "Ressalvada a hipótese de ordem manifestamente ilegal, a prevalência do princípio da estrutura hierarquizada é fundamental para o funcionamento eficiente tanto da companhia quanto da sua empresa (...)". (PEDREIRA, José Bulhões. Acordo de acionista sobre... apud, PATELLA, Laura Amaral; BORES, Leandro Vilarinho; BERNARDES, Lucas Petri; AZEVEDO, Luís André Negrelli de Moura. Deveres Fiduciários dos Administradores. Vinculação dos Administradores. In Mercado de Capitais Brasileiro: Doutrina, Cases e Materials. São Paulo: Quartier Latin, 2012, p. 235); e (iii) "O membro do conselho de administração eleito pela junção de forças em acordo de acionistas está subordinado a dois regimes distintos. O primeiro, aquele correspondente ao dever de lealdade à sociedade e de defender a lei e o estatuto social no exercício de sua atividade. O segundo, decorrente das determinações emanadas dos acionistas participantes do acordo e manifestadas nas reuniões prévias. Em certas ocasiões o conselheiro deverá descumprir as instruções tomadas nas reuniões prévias, toda vez que elas ofenderem o estatuto social e a lei." (VERÇOSA, Haroldo Malheiros Duclerc. Curso de direito comercial. v. 3. $2^{\mathrm{a}}$ ed. São Paulo: Malheiros, 2011, p. 335)

${ }^{280}$ São as posições assumidas por ARAGÃo, DENISE SALLES, MUNHOZ, respectivamente: (i) “(...) O conceito de que os conselheiros são, no Brasil, escolhidos pela sua independência - isto sim, uma regra saudável de boa governança corporativa - é a exceção no Brasil, ao contrário do que sucede em outros países. (...) Seria um absurdo - como acontece hoje - que os acionistas assinem os acordos e, mais adiante, por força de tal ou qual divergência, se invoque a suposta 'liberdade de consciência' para descumprir o pactuado. (...) Não existe, assim, a suposta possibilidade de o conselheiro descumprir o acordo com base na sua 'liberdade de consciência'. Se o fizer, deverá necessariamente basear-se naquelas hipóteses estabelecidas numerus clausus no referido $\S 2^{\circ}$ do art. 118." (ARAGÃO, Paulo Cézar. A disciplina do acordo de acionistas na reforma da Lei das Sociedades por Ações. In LOBO, Jorge (Coord.). Reforma da Lei das Sociedades Anônimas. $2^{\mathrm{a}}$ ed. Rio de Janeiro: Forense, 2002, p. 376-378); (ii) “(...) se as determinações dos acionistas controladores forem contrárias aos interesses da companhia, os membros do conselho de administração podem e devem atuar de acordo com sua convicção pessoal. Ainda seguindo esse raciocínio, entendemos ser inválida a vinculação do voto dos membros do conselho de administração que tenham natureza fiscalizatória a respeito das contas e relatórios, por exemplo, quando da manifestação a respeito das contas e relatórios da diretoria. Nesses casos, a fim de fazer valer o disposto no artigo 139 da Lei 6.404/76, faz-se necessário que os conselheiros atuem de acordo com a sua própria convicção, inclusive como forma de se protegerem de eventual responsabilidade civil." (SALLES, Denise Chachamovitz Leão de. Acordo de Acionistas: um Panorama Evolutivo. In CASTRO, Rodrigo R. Monteiro de; ARAGÃO, Leandro Santos. Sociedade Anônima: 30 anos da Lei 6.404/76. São Paulo: Quartier Latin, 2007, pp. 506-507); e (iii) "Nesse sentido, sempre que receber do acionista controlador orientação contrária aos fins da companhia, tem o administrador o dever de descumprir a ordem, em defesa do interesse da companhia." (MUNHOZ, Eduardo Secchi. Estrutura de Governo dos Grupos Societários de Fato na Lei Brasileira. In CASTRO, Rodrigo Rocha Monteiro de; WARDE JÚNIOR, Walfrido Jorge; GUERREIRO, Carolina Dias Tavares (coord.). Direito Empresarial e Outros Estudos em Homenagem ao Professor José Alexandre Tavares Guerreiro. São Paulo: Quartier Latin, 2013, p. 286) 
(iii) deliberação de assuntos de competência privativa do Conselho de Administração, seja de forma genérica ${ }^{281}$, seja especificando as matérias previstas no art. 142 da LSA passíveis de vinculação ${ }^{282}$;

(iv) quando o conselheiro não for parte do $\operatorname{acordo}^{283} ; \mathrm{e}$

${ }^{281}$ Carvalhosa, Gorga e Gelman e os autores da obra coletiva entitulada "Deveres Fiduciários dos Administradores. Vinculação dos Administradores", já mencionada neste trabalho, também utilizaram esses argumentos para fundamentar sua posição favorável à vinculação relativa: (i) CARVALHOSA, Modesto. A Vinculação dos Administradores ao Acordo de Controle. In WALD, Arnoldo; GONÇALVES, Fernando; SOARES DE CASTRO, Moema Augusta (Coord.). Sociedades Anônimas e Mercado de Capitais. Homenagem ao Prof. Osmar Brina Corrêa-Lima. São Paulo: Quartier Latin, 2011, pp. 41-46; (ii) “(...) fato é que com a alteração da lei 6404, promovida em 2001 pela lei 10.303, a vinculação do voto dos membros do Conselho de Administração eleitos pelos signatários de acordo de acionistas foi recepcionada pelo nosso sistema normativo (...) se a matéria em pauta na reunião do Conselho de Administração for de competência exclusiva do conselho, haverá necessária invasão de competência e expressa ilegalidade, já que, como vimos, a lei das S.A. veda a delegação de competências entre os órgãos societários. Se, por outro lado, a matéria em pauta não for de competência exclusiva do conselho, mas de competência dos acionistas, não haveria invasão de competência e seria legítima a previsão contratual." (GORGA, Érica; GELMAN, Marina. O Esvaziamento Crescente do Conselho de Administração como Efeito da Vinculação de seu Voto a Acordos de Acionistas no Brasil. Prêwmio IBGC Itaú Academia e Imprensa, 2012, pp. 7 e 16); e (iii) "Os administradores das sociedades anônimas são os encarregados da prática dos atos de gestão e de sua representação legal (...). Esses poderes são conferidos por lei e pelos estatutos sociais, aos quais cabe a difícil missão de delinear eventuais limitações dessas competências, norteadas pelo objeto social, e que são, efetivamente, tão amplas quanto a própria capacidade jurídica. (...) Portanto, a nova disposição legal sobre vinculação dos

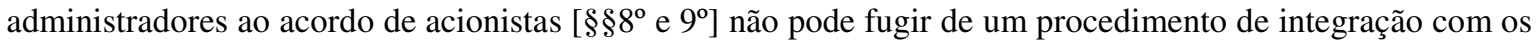
demais deveres e valores impostos aos administradores, legal e estatutariamente." (PATELLA, Laura Amaral; BORES, Leandro Vilarinho; BERNARDES, Lucas Petri; AZEVEDO, Luís André Negrelli de Moura. Deveres Fiduciários dos Administradores. Vinculação dos Administradores. In Mercado de Capitais Brasileiro: Doutrina, Cases e Materials. São Paulo: Quartier Latin, 2012, p. 239)

${ }^{282}$ Vide as opiniões de WALD, BOCATER E CAMARGO (já mencinada no Capítulo V, no sentido de serem passíveis de vinculação os incisos VI, VII e VIII do art. 142, da LSA), TORNOVSKY e CEREZETTI: (i) WALD, Arnoldo. A evolução do regime do conselho de administração, os acordos de acionistas e os impedimentos dos conselheiros decorrentes de conflito de interesses. In Revista de Direito Bancário, do Mercado de Capitais e da Arbitragem. no 11. São Paulo: Revista dos Tribunais, pp. 13-30; (ii) CAMARGO, João Laudo; BOCATER, Maria Isabel do Prado. Conselho de Administração: seu Fucionamento e Participação de Membros Indicados por Acionistas Minoritários e Preferencialistas. In LOBO, Jorge (Coord.). Reforma da Lei das Sociedades Anônimas. $2^{a}$ ed. Rio de Janeiro: Forense, 2002, p 400; (iii) TORNOvSKI, por sua vez, propõe sua classificação, dividida em dois critérios: o primeiro consistiria em determinar as matérias inerentes ao exercício do poder de controle que possuem natureza deliberativa (incisos I, II, VI, VII, VIII e IX do art. 142) e, o segundo, as matérias de competência do conselho de natureza fiscalizatória e administrativa (incisos III, IV e V do mesmo artigo), sendo que apenas com relação às matérias de natureza deliberativa os membros do conselho de administração ficariam vinculados às determinações do acordo de acionistas. (TORNOVSKY, Miguel. Acordos de Acionistas sobre o Exercício do Poder de Controle. Análise das Principais Alterações Introduzidas ao art. 118 da Lei das S.A. pela Lei 10.303/2001. In Revista de Direito Mercantil, Industrial, Econômico e Financeiro. $n^{\circ}$ 127. São Paulo: Malheiros, 2002, p. 102); e (iv) “(...) a nova norma não afasta o sistema de competências previsto na Lei 6404/1976 (art. 139 da Lei Societária). Isso significa dizer que as decisões de alguns acionistas aprovadas em reunião prevista no acordo entre eles celebrado não devem versar sobre assuntos que escapam à esfera das competências dos próprios participantes do capital e abrangem as funções dos administradores. Não há autorização, nesses termos, para que as competências privativas legalmente traçadas sejam desrespeitadas." (CEREZETTI, Sheila Christina Neder. Administradores Independentes e Independência dos Administradore. Regras Societárias Fundamentais ao Estímulo do Mercado de Capitais Brasileiro. In VON ADAMEK, Marcelo Vieira (Coord.). In Temas de Direito Societário e Empresarial Contemporâneos. Liber Amicorum Prof. Dr. Erasmo Valladão Azevedo e Novaes França. São Paulo: Malheiros, 2011, p. 591) 
283 (i) CALIXTO SALOMÃo possui uma opinião singular a respeito do tema, pois argumenta que o acordo de acionistas não pode contrariar a própria estrutura societária (i.e., modificar estatutos sociais ou lei). Consequência disso, ele entende que é "possível apenas predefinir orientação de votos de acionistas e conselheiros (desde que vinculados pelo acordo como acionistas) em reuniões prévias, parassocietárias, que essas sim podem aprovar matérias com o quórum estabelecido em acordo." (destaques nossos) (SALOMÃO FILHO, Calixto. O Novo Direito Societário. $4^{\mathrm{a}}$ ed. São Paulo: Malheiros, 2011, p. 139). Calixto chega a elogiar o legislador brasileiro de realista e fiel a nossa cultura ao inserir os $\S \S 8^{\circ}$ e $9^{\circ}$ na LSA. Todavia, sua obra sugere uma nova forma de conceber o direito societário (análise estruturalista) e um papel ativo da norma de criar valor e não apenas se submeter à realidade; e (ii) CARVALHOSA contraria tal entendimento sustentando que "essa vinculação se dá muito embora não tenham sido esses mesmos administradores partes signatárias dele [acordo de acionistas], em sentido formal. Mas o são em sentido substancial." (CARVALHOSA, Modesto. Acordo de Acionistas. São Paulo: Saraiva, 2011, p. 241)

${ }^{284}$ Curioso notar a seguinte opinião de EIZIRIK, com a qual concordamos totalmente, embora soe contraditório a outros posicionamentos do autor sobre vinculação, mencionados neste trabalho (como no subcapítulo anterior): "A independência dos administradores em relação a quem os elegeu adquire especial relevo, em se tratando de companhias abertas, sobre as quais recai indiscutivelmente o interesse público. Com efeito, o grau de exigência em relação aos administradores de companhias abertas é ainda superior do que às demais sociedades anônimas, na medida em que mobilizam a poupança popular.” (EIZIRIK, Nelson. Independência dos administradores em relação ao acionista controlador. Relações entre companhias integrantes de grupo de fato. In Estudos de Direito Empresarial. São Paulo: Saraiva, 2010, p. 369)

${ }_{285}$ Os seguintes autores também utilizam-se desse argumento, para fundamentar sua posição acerca da vinculação relativa dos administradores a acordo de acionistas, COMPARATO, VERÇOSA, VALLADÃo, SZTAJN, adamek, Abreu, Munhoz, Cerezetti, ana Rafaela Medeiros, Salles de Toledo e Gorga e GELMAN, respectivamente: (i) "onde há competência privativa há também, por via de estrita consequência, a indelegabilidade de poderes ou funções. A rigor, portanto, a Lei 6.404 não carecia dizer, em seu art. 139 que 'as atribuições e poderes conferidos por lei aos órgãos de administração não podem ser outorgados a outro órgão, criado por lei ou pelo estatuto'. A regra decorre, naturalmente, do princípio da exclusividade de competências, que na história do direito político tem nome de "princípio da divisão dos Poderes". (COMPARATO, Fábio Konder. Competência privativa do conselho de administração para designação de diretores, em companhia aberta: ineficácia de cláusula de contrato social da holding, ou de eventual acordo de acionistas, para regular a matéria. In Novos ensaios e pareceres de direito empresarial. Rio de Janeiro: Forense, 1981). Observamos que Comparato manifestou-se sobre o tema antes das alterações à LSA de 2001; (ii) “(...) não pode ser aceito que o $\S 8^{\circ}$ do art. 118 da LSA haja aniquilado a independência do conselheiro de administração, conforme pensam alguns (...). Do ponto de vista da Teoria Organicista, é indispensável que o conselheiro de administração tenha independência para a realização das tarefas que a lei e/ou o estatuto social lhe outorgam. Esta independência é essencial principalmente em relação ao acionista controlador, que não pode utilizar seu poder de controle para obrigar o conselheiro a agir de forma contrária ao objeto social, em termos mais específicos. (...) A independência em causa deve ocorrer mesmo em relação a conselheiros eleitos por força de acordo de acionistas (...)." (VERÇOSA, Haroldo Malheiros Duclerc. Curso de direito comercial. v. 3. $2^{a}$ ed. São Paulo: Malheiros, 2011, pp 433-434); (iii) “(...) sendo órgãos da companhia, e não meros mandatários [da companhia ou da assembleia geral], os administradores, no seu âmbito de competência, não têm o dever de seguir instruções de ninguém, nem mesmo da assembleia geral (...) é obvio que, na prática, desavindo-se com o controlador, poderão os administradores até ser demitidos ad nutum pela assembleia geral. Mas esse é o preço que um administrador consciencioso e cumpridor dos seus deveres tem de pagar pela obediência à lei." (FRANÇA, Erasmo Valladão Azevedo e Novaes. Dever de Informar dos Administradores de Companhias Abertas. Inexistência de Submissão ao Acionista Controlador. In Temas de Direito Societário, Falimentar e Teoria da Empresa. São Paulo: Malheiros, 2009, p. 367 e 370); (iv) "Dessa vinculação cogente, pois votos declarados contrariamente ao acordo não são computados, poderá resultar sério conflito com a norma do art. 154 da Lei. Compor as duas regras - a do $\$ 8^{\circ}$ ao art. 118 com a do art. 154 - é tarefa complexa e ingrata. O art. 154 impõe ao administrador o dever de exercer suas atribuições para lograr os interesses da companhia, satisfazendo as exigências do bem público e da função social da empresa. Vinculado a acordo de acionistas, deve declarar o voto nos termos do ajustado o que não elide eventual conflito entre o interesse predominante do mandante do voto, o bem público e a função social da empresa. Como aquilatar a observância do dever de lealdade para com a companhia com a 'lealdade' ou fidelidade aos 
Exemplo maior da opinião de que existem limites à vinculação de administradores a acordo de acionistas é a de CARvalhosa, no sentido de que somente as matérias de natureza extraordinária previstas no acordo de controle poderiam ser objeto de vinculação. As competências ordinárias, no entanto, não poderiam ser vinculadas, devendo o administrador exercer livremente seu dever de independência em sua condução ${ }^{286}$.

interesses dos acionistas vinculados pelo acordo de votos?" (SZTAJN, Rachel. Acordo de Acionistas. In SADDI, Jairo (Org.). In Fusões e Aquisições: Aspectos Jurídicos e Econômicos. São Paulo: IOB, 2002, pp. 288-289); (v) "os acordos de acionistas não podem usurpar, direta ou indiretamente, competência privativa e tampouco impor ao administrador a prática de ato que seja lesivo ao interesse social e pelo qual possa vir a ser responsabilizado (LSA, art. 158, I e II)". (VON ADAMEK, Marcelo Vieira. Responsabilidade dos administradores de S.A. e as ações correlatas. São Paulo: Saraiva, 2009, p. 145); (vi) "O administrador deve ter liberdade para exercer suas competências, inclusive afastando a decisão se entender que ela não é a que melhor promove o interesse social”. (ABREU, Jorge Manoel Coutinho de. Governança das sociedades comerciais. $2^{\mathrm{a}}$ ed. Coimbra: Almedina, 2010, p. 110); (vii) "Se, de um lado, a lei estabelece a independência dos órgãos da administração (art. 139), de outro reconhece ao acionista controlador, como se viu, o poder de orientar a atuação dos administradores. Não há incoerência nessa solução, desde que se reconheçam os limites do poder do controlador, abrindo-se espaço para a independência dos administradores." (MUNHOZ, Eduardo Secchi. Estrutura de Governo dos Grupos Societários de Fato na Lei Brasileira. In CASTRO, Rodrigo Rocha Monteiro de; WARDE JÚNIOR, Walfrido Jorge; GUERREIRO, Carolina Dias Tavares (coord.). Direito Empresarial e Outros Estudos em Homenagem ao Professor José Alexandre Tavares Guerreiro. São Paulo: Quartier Latin, 2013, pp. 285-286); (viii) “A alteração da Lei Acionária, adotada em suposto movimento de valorização de boas práticas de governança, contraria, sob uma interpretação literal, a regra básica de autonomia da administração, obrigando conselheiros, que têm o dever legal de independência, a agirem de maneira dependente, ou seja, a manifestarem voto em consonância com o pactuado por aqueles que os elegeram." (CEREZETTI, Sheila Christina Neder. Administradores Independentes e Independência dos Administradores. Regras Societárias Fundamentais ao Estímulo do Mercado de Capitais Brasileiro. In VON ADAMEK, Marcelo Vieira (Coord.). In Temas de Direito Societário e Empresarial Contemporâneos. Liber Amicorum Prof. Dr. Erasmo Valladão Azevedo e Novaes França. São Paulo: Malheiros, 2011, p. 590); (ix) "O administrador deve ter liberdade para exercer suas competências, inclusive afastando a decisão se entender que ela não é a que melhor promovo o interesse social. (...) Ao permitir a vinculação dos administradores aos acordos, a nova disciplina viola esse dever [processo decisório razoável e bem informado - reasonable decision making process]. Ninguém poderia advogar que um administrador obrigado a cumprir, cegamente, as orientações do controlador estaria agindo de forma refletida, instruída e ponderada. A vinculação impõe uma postura passiva ao administrador, que agirá não tendo em vista a decisão que razoavelmente informado entendeu ser a melhor para a companhia, mas aquela que foi imposta pelo acordo." (MEDEIROS, Ana Rafaela Martinez. A possibilidade de vincular administradores de companhias abertas aos acordos de acionistas. In Revista de Direito Empresarial. $\mathrm{n}^{\circ}$ 1. Belo Horizonte, 2012. Disponível em <http://www.bidforum.com.br/bid/PDI0006.aspx?pdiCntd=78789>. Último acesso em 25.02.2013); (x) Sobre o $\$ 8^{\circ}$ : "O dispositvo contraria as modernas conquistas da governança corporativa, e confere ao chairman - normalmente eleito pelo controlador, quando não se tratar do próprio - o poder de controlar o órgão, na medida em que impõe aos conselheiros o dever de votar num determinado sentido, sob pena de não ser computado o voto. Com isso, o conselheiro tem prejudicada uma de suas características fundamentais: a autonomia. (...) [Sobre o $\S 9^{\circ}$ ] "a regra é autoritária e pressupõe um conselheiro submisso às determinações de quem o elegeu. Se esse conselheiro ousar insurgir-se, estará sujeito à pena de censura, aplicada em público e sem direito de defesa." (TOLEDO, Paulo F. C. Salles de. Modificações Introduzidas na Lei das Sociedades por Ações, quanto à Disciplina da Administração das Companhias. In LOBO, Jorge (Coord.). Reforma da Lei das Sociedades Anônimas. $2^{\mathrm{a}}$ ed. Rio de Janeiro: Forense, 2002. pp. 427-428); e (xi) GORGA, Érica; GELMAN, Marina. O Esvaziamento Crescente do Conselho de Administração como Efeito da Vinculação de seu Voto a Acordos de Acionistas no Brasil. Prêmio IBGC Itaú Academia e Imprensa, 2012.

${ }^{286}$ CARVAlHOSA refinou seu entendimento e acredita que a vinculação não é absoluta, e seria aplicável somente a matérias extraordinárias. Aos atos de administração ordinários, i.e., "aqueles previstos no estatuto como de competência originária da diretoria (artigo 143 da LSA) ou do conselho de administração (artigo 142 da LSA)" aplica-se o conceito de que "o regime de independência e autonomia dos administradores é 
Aduz o jurista:

(...) as cláusulas que vinculem os votos dos administradores de forma indiscriminada são inválidas e ineficazes. (...) não pode a cláusula ser vazia, pois isso representaria uma delegação de voto plena à comunhão de controladores (...). Nessas hipóteses de vinculação indiscriminada e universal, os administradores eleitos pela comunhão de controladores serão livres para votar com absoluta independência, em todas as matérias, pois nenhuma delas é enumerada no texto do acordo. ${ }^{287}$

\subsection{Impossibilidade de vinculação e o papel da autorregulação}

Há posicionamentos crescentes, e também de renome, em sentido totalmente contrário à vinculação de administradores a acordo de acionistas. São autores (e até entidades, como o IBGC) que sustentam uma visão contrária, por meio da bandeira das melhores práticas de governança corporativa. Para eles, a vinculação contrariaria a independência (e outros deveres fiduciários) dos administradores, na medida em que lhe restringe a liberdade de ação e lhes impõe uma postura passiva ${ }^{288}$.

absoluto". CARVALHOSA, Modesto. A Vinculação dos Administradores ao Acordo de Controle. In WALD, Arnoldo; GONÇALVES, Fernando; SOARES DE CASTRO, Moema Augusta (Coord.). Sociedades Anônimas e Mercado de Capitais. Homenagem ao Prof. Osmar Brina Corrêa-Lima. São Paulo: Quartier Latin, 2011, pp. 41-46.

${ }^{287}$ CARVALHOSA, Modesto. A Vinculação dos Administradores ao Acordo de Controle. In WALD, Arnoldo; GONÇALVES, Fernando; SOARES DE CASTRO, Moema Augusta (Coord.) Sociedades Anônimas e Mercado de Capitais. Homenagem ao Prof. Osmar Brina Corrêa-Lima. São Paulo: Quartier Latin, 2011, p. 45.

${ }^{288}$ São defensores da impossibilidade de vinculação os seguintes autores, BARROSO, VERGUEIRO, CUNHA, NUNES e SIMÕES, respectivamente: (i) "Nossa opinião é no sentido de que o $§ 8^{\circ}$ não pode vincular o membro do conselho de administração, pois assim não foi expresso na lei e porque um contrato civil, como é o caso do acordo de acionistas, não pode vincular quem não o subscreve. Somos da opinião de que o conselheiro continua não apenas podendo, mas também devendo, votar na melhor forma para a companhia, independentemente do que dispõe o acordo de acionistas. A nova disposição legal apenas determina que o presidente do conselho de administração deve desconsiderar o voto, o qual ele entenda não esteja em linha com o que prevê o acordo de acionistas." (BARROSO, Carlos Henrique. A responsabilidade civil do conselheiro de administração e o acordo de acionistas. Revista dos Tribunais. $\mathrm{n}^{\circ} 834,2005$, p. 54); (ii) “(...) a falta de coerência dos $\S \S 8^{\circ}$ e $9^{\circ}$ do art. 118 (...) é um critério para não considerá-los como normas autorizantes da revogação do modelo [criado pela interpretação conjunta dos arts. 139, 153, 154, 155 e 156] (...) qualquer tentativa de promover o seu afastamento com base em um acordo de acionistas traz como consequência a caracterização do acordo como desprovido de validade jurídica (...), pode ser considerado como objeto ilícito de acordo de acionistas (...) entendemos que os novos parágrafos $8^{\circ}$ e $9^{\circ}$ representam uma hipótese de erro do legislador. Dessa forma, como conclusão, entendemos que o conselheiro eleito nos termos de um acordo de acionistas deve continuar a votar conforme o seu entendimento de aplicação dos deveres de lealdade e diligência, não podendo o presidente do Conselho de Administração não computar os votos proferidos em desconformidade com o acordo de acionistas em questão." (VERGUEIRO, Carlos Eduardo. Acordo de Acionistas e a Governança das Companhias. São Paulo: Quartier Latin, 2010, pp. 198200); (iii) “A situação [inclusão dos $\S \S 8^{\circ}$ e $9^{\circ}$ ao art. 118] causa estranheza, já que em evidente conflito com 
Com relação à autorregulação (tratada no Capítulo $\mathrm{V}$ deste trabalho), apenas o IBGC trata especificamente da vinculação. No item 1.3 do Código de Melhores Práticas de Governança Corporativa ${ }^{289}$, bem como na Carta Diretriz de $2008^{290}$, o instituto considera que os $\S \S 8^{\circ}$ e $9^{\circ}$ do artigo 118 da LSA representam risco de enfraquecimento da independência e responsabilidade individual dos conselheiros. Entende, ainda, que a vinculação somente pode ser admitida nas hipóteses que não adentrem na competência atribuída ao órgão, em que "o conselheiro deve examinar criticamente a orientação de voto que lhe é passada, só devendo segui-la se entender que essa é a medida que melhor atende ao interesse social" 291 e, acima de tudo, em que a orientação seja recebida apenas como "mera recomendação".

a disciplina de independência dos membros do conselho e, especificamente, com o disposto no art. 154, parágrafo único. Isso para não dizer que vem na contramão dos mais elementares princípios de governança corporativa. Juristas de escol já se manifestaram nesse sentido. Afirma Simões: 'Essas disposições [§§ $8^{\circ}$ e $9^{\circ}$ do art. 118] criam uma distorção dos controles de legitimidade do voto, transformando na prática em 'ex post' a verificação da legalidade das obrigações decorrentes de acordos de acionistas. Com efeito, esses novos dispositivos negam toda a formulação do princípio organicista ao transformar os administradores, eleitos por acionistas signatários de acordos parassociais, em delegados ou representantes desses acionistas, e ao permitir que o presidente do conclave recuse o voto que, a seu juízo de valor, viole o acordo de acionistas e, mais ainda, que um acionista membro do conselho de administração vote por outro, ausente, ou que venha a abster-se na votação." (CUNHA, Rodrigo Ferraz Pimenta da. Estrutura de Interesses nas Sociedades Anônimas - Hierarquia e Conflitos. São Paulo: Quartier Latin, 2007, p. 319); (iv) "A nova redação do art. 118 , $\S \S 8^{\circ}$ e $9^{\circ}$ apresenta uma distorção no regime da responsabilidade pessoal do Conselheiro (art. 158) decorrente, é certo, da presumível independência funcional com a qual deve exercer suas funções no Colegiado para o qual foi eleito. Logo, é prudente explicitar - nos Acordos de Acionistas - as regras de responsabilização (ou não) do Conselheiro em virtude da obediência a uma orientação de voto com a qual não concorde, como também as circunstâncias em que os riscos de uma orientação de voto são assumidos pelos responsáveis por esta, isolada ou solidariamente com o administrador. Tal procedimento, no entanto, não pode ser considerado como plenamente satisfatório e/ou seguro." (NUNES, Marcio Tadeu G.. O acordo de acionistas: questões controvertidas acerca da nova reclamação conferida pela lei. 10.303/01 aos parágrafos $8^{\circ}$ e $9^{\circ}$ do art. 118 da lei das S.A. e aspectos correlatos. Revista da AARJ. v. 3. Rio de Janeiro, 2003, p. 8-11, apud, CUNHA, Rodrigo Ferraz Pimenta da. Estrutura de Interesses nas Sociedades Anônimas - Hierarquia e Conflitos. São Paulo: Quartier Latin, 2007, pp. 319-320); e (v) SIMÕES, Paulo C. G. Governança corporativa e o exercício de voto nas S.A. Rio de Janeiro: Lumen Juris, 2003.

${ }^{289}$ Os acordos de sócios "não devem devem vincular ou restringir o exercicio do direito de voto de quaisquer membros do Conselho de Administração, os quais deverão cumprir fielmente seu dever de lealdade e diligencia para com a organizacao. Esse dever deve sobrepor os interesses particulares daqueles que os indicaram" (Instituto Brasileiro de Governança Corporativa. Código de Melhores Práticas de Governança Corporativa. $4^{\text {a }}$ ed. São Paulo: IBGC, 2009, item 1.3, p. 22)

${ }^{290}$ Instituto Brasileiro de Governança Corporativa. Independência dos Conselheiros de Administração: fundamento jurídico para a mudança do artigo 118 , $\$ \$ 8^{\circ}$ e $9^{\circ}$, da Lei $n^{\circ}$ 6.404/76. CUNHA, Mauro Rodrigues (Coord.). São Paulo: IBGC, 2008 (Série Carta Diretrizes - 1).

${ }^{291}$ Instituto Brasileiro de Governança Corporativa. Independência dos Conselheiros de Administração: fundamento jurídico para a mudança do artigo 118, $\$ \$ 8^{\circ}$ e $9^{\circ}$, da Lei $n^{\circ}$ 6.404/76. CUNHA, Mauro Rodrigues (Coord.). São Paulo: IBGC, 2008 (Série Carta Diretrizes - 1), p. 17. 
O Novo Mercado é silente sobre o assunto. O trabalho de Gorga e Gelman identificou, inclusive, companhias listadas em tal segmento, com cláusulas vinculativas de conselheiros $^{292}$.

\subsection{Análise empírica de Gorga e Gelman}

Em 2009, GoRGA publicou importante trabalho empírico de análise de conteúdo e tipos de acordos de acionistas e suas consequências para a estrutura de propriedade acionária das companhias listadas ${ }^{293}$. O estudo tinha por base dados levantados em 2007 e identificou a incidência de $50 \%$ de acordos de acionistas de companhias sem acionista controlador majoritário, sendo que destes, 76,29\% regulava o exercício do poder de controle. Dentro deste universo, 61,90\% continha cláusulas de vinculação de voto dos membros do conselho de administração.

Em subsequente rica e premiada análise, desta vez conduzida também por GELMAN, em $2012^{294}$, as autoras atualizaram o levantamento de dados de 2007 e contribuíram com novas informações. O trabalho envolveu a análise, em maio de 2012, de dados sobre estrutura de propriedade de 181 companhias listadas nos segmentos especiais de governança da BM\&FBovespa.

Dentro de tal universo, o estudo identificou 90 companhias sujeitas a acordos de acionistas, dos quais 60 possuíam cláusulas vinculantes aos administradores, sendo que 35 possuíam as denominadas "cláusulas guarda-chuva" (i.e., todos os assuntos a serem deliberados pelo conselho deveriam seguir a instrução fornecida pelos acionistas reunidos em reunião prévia) e 25 continham “cláusulas específicas" (i.e., determinadas matérias previstas no acordo que, quando deliberadas pelo conselho, exigiriam prévia instrução dos acionistas reunidos em reunião prévia).

${ }^{292}$ GORGA, Érica; GELMAN, Marina. O Esvaziamento Crescente do Conselho de Administração como Efeito da Vinculação de seu Voto a Acordos de Acionistas no Brasil. Prêmio IBGC Itaú Academia e Imprensa, 2012.

${ }_{293}$ GORGA, Érica. Changing the paradigm of stock ownership from concentrated towards dispersed ownership? Evidences from Brazil and consequences for emerging countries. Nothwestern Journal of International Law \& Business, v. 29, n. 2, 2009.

${ }^{294}$ GORGA, Érica; GELMAN, Marina. O Esvaziamento Crescente do Conselho de Administração como Efeito da Vinculação de seu Voto a Acordos de Acionistas no Brasil. Prêmio IBGC Itaú Academia e Imprensa, 2012. 
As autoras apontam a "clara ilegalidade e falta de preocupação contida na redação (...)" de determinados acordos que "com todas as letras, contraria[m] a lei delegando a competência do Conselho de Administração para os acionistas" 295.

Na opinião das autoras, sempre que uma matéria de competência privativa do conselho de administração for submetida ao prévio crivo dos acionistas, haveria ilegalidade por delegação de competência ${ }^{296}$.

As autoras citam até mesmo o exemplo de acordos vinculando o voto de conselheiros independentes e concluem:

Neste contexto, o interesse do controlador representado no acordo de acionistas não pode ser presumido como de acordo com o interesse social da companhia. Isso porque o controlador estaria se utilizando do acordo de acionistas para usurpar uma competência legalmente atribuída ao Conselho de Administração e, neste caso, nenhuma escola (contratualista, institucionalista ou qualquer outra) sustentaria que tal ilegalidade representaria o interesse social. ${ }^{297}$

O trabalho empírico das autoras é essencial para verificarmos que o tema objeto deste trabalho não é teórico e encontra-se amplamente difundido pela prática empresarial $^{298}$.

${ }^{295}$ GORGA, Érica; GELMAN, Marina. O Esvaziamento Crescente do Conselho de Administração como Efeito da Vinculação de seu Voto a Acordos de Acionistas no Brasil. Prêmio IBGC Itaú Academia e Imprensa, 2012, p. 13.

${ }^{296}$ GORGA, Érica; GELMAN, Marina. O Esvaziamento Crescente do Conselho de Administração como Efeito da Vinculação de seu Voto a Acordos de Acionistas no Brasil. Prêmio IBGC Itaú Academia e Imprensa, 2012, p. 16.

${ }^{297}$ GORGA, Érica; GELMAN, Marina. O Esvaziamento Crescente do Conselho de Administração como Efeito da Vinculação de seu Voto a Acordos de Acionistas no Brasil. Prêmio IBGC Itaú Academia e Imprensa, 2012, pp. 19-20.

${ }^{298}$ Tecemos uma crítica construtiva ao trabalho das autoras, já que, segundo elas “(...) é entendimento unânime que aquilo que a lei das S.A. atribuiu como sendo de competência privativa do Conselho de Administração, e que se encontra previsto no artigo 142 e seus incisos I, II, III, IV, V e IX, bem como da Diretoria não pode ser matéria de acordo de acionistas, sob pena de nulidade e ineficácia do acordo." (GORGA, Érica; GELMAN, Marina. O Esvaziamento Crescente do Conselho de Administração como Efeito da Vinculação de seu Voto a Acordos de Acionistas no Brasil. Prêmio IBGC Itaú Academia e Imprensa, 2012, p. 9) Conforme demonstrado neste trabalho, diversos autores não abordam este ponto específico ao tratar da vinculação e a colocam de forma genérica. Todavia, verificamos que alguns autores chegam a mencionar expressamente a possibilidade de a assembleia geral avocar para si matérias de competência privativa do conselho (v. opinião de LoBo, evidenciada acima). Destacamos, ainda, o entendimento de TORNOVSKI (também tratado acima), sobre a possibilidade de o acordo de comando vincular as matérias do art. 142 que tenham natureza deliberativa, quais sejam, os incisos I, II, VI, VII, VIII e IX. 
A partir de contribuições como essa de GoRGA e GELMAN, este trabalho e diversos outros aqui citados, nossa expectativa é a de que todos os participantes do mercado, a CVM e o Poder Judiciário (embora este não analise conflitos de companhias listadas no Novo Mercado) identifiquem o que está havendo e os potenciais prejuízos de não se revisar o modelo. Entre os prejuízos, notadamente o esvaziamento do conselho de administração e o aumento da possibilidade de extração de benefícios privados de controle pelo controlador. 


\section{VINCULAÇÃO DA ADMINISTRAÇÃO AO ACORDO DE ACIONISTAS. PRECEDENTES}

\subsection{Esfera judicial}

E o que diz a jurisprudência a respeito do tema? Ainda que não haja tantos precedentes sobre o tema quanto seria desejável, para que se auferisse uma posição absolutamente dominante de alguma das correntes, atualmente podemos dizer que prevalece o entendimento de que reuniões prévias de acionistas podem sim vincular decisões do conselho. Vejamos abaixo o detalhamento de nossa pesquisa.

No âmbito judicial, identificamos um total de:

(i) três decisões favoráveis à vinculação ${ }^{299}$ (observado que a mais recente delas menciona não ser absoluta a vinculação, resguardando-se o interesse social); e

(ii) duas contrárias ${ }^{300}$ à vinculação (destacando-se que elas julgaram fatos de antes de 2001 , i.e., quando a LSA ainda não continha os $\S \S 8^{\circ}$ e $9^{\circ}$ do art. 118 , o que modifica e enfraquece bastante a utilidade desses precedentes).

\footnotetext{
299 (i) "Como regra geral o acordo de acionista vincula os conselheiros à orientação de voto do acionista. Contudo, essa regra não é absoluta, devendo o conselheiro não cumprir tal orientação caso a mesma seja contrária ao interesse social, eivada de ilegabilidade ou abusiva, podendo inclusive ser responsabilizado pelos prejuízos causados por sua conivência, negligência ou omissão (art. 158 da LSA)." (2 $2^{\text {a }}$ Câmara Cível do TJRJ. Ap. no 2004.001.36522. Des. Leila Mariano. Julgado em 16.03.2005); (ii) "Agravo de instrumento. Liminar em medida de cautelar inominada, sustando os efeitos da Reunião do Conselho de empresa, realizada sem observância do Acordo de Acionistas celebrado validamente. Fumus boni iuri e periculum in mora presentes. Recurso Desprovido. Decisão Confirmada." (13 ${ }^{\mathrm{a}}$ Câmara Cível do TJRJ. A.I. no 1998.002.10209. Des. Gilberto Fernandes. Julgado em 26.08.1999); e (iii) o Tribunal entendeu perfeitamente válida e vinculante a disposição do acordo de acionistas que nominava diretores da sociedade, ainda que estes devessem ser eleitos pelo conselho de administração. Desse modo, nas companhias fechadas, o acordo de acionistas devidamente arquivado deveria ser seguido pelo conselho de administração que, por sua vez, não possui "autonomia para ignorar o acordo". (Ap. 219.618-1/6, 6ª Câmara Cível. Rel. Des. Melo Colombi, RT 706/84. Julgado em 03.02.1994)

300 (i) “(...) o acordo de acionistas pode regular o voto que os participantes do acordo tenham que dar na qualidade de acionistas, mas não aquele que tenham que dar como eventuais administradores da sociedade." (9a Câmara de Direito Privado do TJSP. A.I. 137.578-4/6-00. Des. Aldo Magalhães. Julgado em 15.02.2000); e (ii) "Não se reveste da aparência do bom direito (...), o entendimento de que o acordo de acionista obriga os membros do conselho de administração." (9a Câmara de Direito Privado do TJSP. A.R. 145-141/8-01 e A.I. 145.141-4/6-00. Des. Aldo Magalhães. Julgado em 04.04.2000)
} 


\subsection{Esfera administrativa}

Na esfera administrativa (âmbito da CVM), tratando de acordos envolvendo companhias abertas, portanto, não temos conhecimento de qualquer decisão que verse especificamente sobre o tema ${ }^{301}$.

\footnotetext{
${ }^{301}$ Embora não tenhamos identificado precedentes tratando diretamente sobre o tema da vinculação no âmbito administrativo, há algumas passagens de decisões da CVM que tangenciam alguns dos assuntos aqui discutidos (especialmente o dever de independência previsto no artigo $154, \S 1^{\circ}$ da LSA): (i) “(...) o administrador eleito por grupo que promove a desconvocação de AGE, sem a prévia anuência do Conselho de Administração e sem que houvesse interesse social efetivo a amparar a sua conduta, viola o art. 154 da LSA” (cf. CVM, Proc. n. RJ-7229/2005, Rel. Pres. Marcelo Fernandez Trindade)”; e (ii) “(...) o administrador deve exercer as atribuições que a lei e o estatuto lhe conferem para lograr os fins e no interesse da companhia, satisfeitas as exigências do bem público e da função social da empresa. Decisões tomadas pelo Conselho de Administração que não se inspiraram no propósito de beneficiar a companhia ou os seus acionistas, mas apenas o acionista controlador, violam o art. 154 da LSA." (CVM, Proc. n. RJ-1443/2005, Rel. Dir. Pedro Oliva Marcílio de Sousa)
} 


\section{VINCULAÇÃO DA ADMINISTRAÇÃO NO DIREITO COMPARADO}

Verificaremos, neste Capítulo, o que o Direito Comparado tem a nos mostrar sobre o tema em discussão $0^{302}$.

Em Portugal ${ }^{303}$, o alcance do acordo parassocial é bem mais restrito do que o nosso. Por lá, a natureza parassocietária é estrita e a lei veda expressamente que ele verse sobre a conduta de terceiros que não os acionistas. Não é possível, por decorrência lógica, portanto, vincular a administração aos acionistas, no âmbito de acordo.

É interessante a justificativa de CORDEIRO (citado por CARVALHOSA) ${ }^{304}$, no sentido de que, se o acordo pudesse regular a atuação da administração, a estrutura orgânica legal seria subvertida e os envolvidos, iludidos ${ }^{305}$.

Esse é justamente o ponto amplamente discutido pela doutrina brasileira, evidenciado nos capítulos anteriores. A vinculação desenfreada da administração aos

\footnotetext{
302 Com a ressalva oportuna de ADAMEK, “(s)abe-se que o estudo do Direito - em específico o do direito societário - se enriquece mediante uma abordagem dotada de extensão espacial, desde que o intérprete esteja atento às peculiaridades dos sistemas estudados". (VON ADAMEK, Marcelo Vieira. Responsabilidade dos Administradores de S.A. e as Ações Correlatas. São Paulo: Saraiva, 2009, p. 577)

303 "Em Portugal, o art. 17 do CSC restringe o alcance dos acordos parassociais, que não podem versar sobre a "conduta dos intervenientes ou de outras pessoas no exercício de funções de administração ou de fiscalização." (CARVALHOSA, Modesto. Comentários à lei das sociedades anônimas. v.2. $5^{\mathrm{a}}$ ed. São Paulo: Saraiva, 2011, p. 146)

304 “(...) Comentando a regra legal, Antonio Menezes Cordeiro explica que 'a administração e a fiscalização ficam fora do universo aberto aos acordos parassociais. Quando muito, poderíamos admitir que o acordo visasse aspectos que, sendo da competência da assembleia geral, pudessem refletir-se na administração e fiscalização (...). A razão dogmática do art. 17\%/2 parece clara (...) admitir-se acordos parassociais com incidências na administração e na fiscalização equivaleria a permitir, a latere, uma organização diferente da do pacto social. A tipicidade societária perderia sentido, uma vez que a verdadeira orgância seria parassocial. Além disso, seriam iludidos todos os preceitos relativos ao pacto social e às suas alterações, escritura, registro e diversas fiscalizações'." (CORDEIRO, Antonio Menezes. Manual de direito das sociedades, cit., v.1, n. 228, pp. 655-656, apud, CARVALHOSA, Modesto. Comentários à lei das sociedades anônimas. v.2. $5^{\text {a }}$ ed. São Paulo: Saraiva, 2011, p. 146)

305 "Também no direito português, colhe-se claro o entendimento de que os acordos parassociais não podem versar sobre a conduta dos administradores, em virtude da prevalência de seus deveres. (...) Cf. Hugo Lança Silva, in Acordos Parassociais: 'Tem-se entendido que o efeito útil desta proibição seria impedir que os administradores actuassem sob a direção ou influência dos sócios o que traduzir-se-ia numa delegação de poderes, expressamente condenada pelos arts. 391 n 6 e 252 n 5, ambos do CSC; estes deixam de ser um órgão da sociedade para se tornarem em meros mandatários dos sócios sindicados'." (BOCATER, Maria Isabel do Prado. Conselho de Administração: seu Fucionamento e Participação de Membros Indicados por Acionistas Minoritários e Preferencialistas. In LOBO, Jorge (Coord.). Reforma da Lei das Sociedades Anônimas. $2^{\mathrm{a}}$ ed. Rio de Janeiro: Forense, 2002, p. 419)
} 
acionistas desnatura e esvazia a administração, tornando inócua e teórica a estrutura societária imaginada pela LSA.

VERGUEIRO ensina que, também na Itália, “(...) não há qualquer disposição que permita a sobreposição do acordo de acionistas ao funcionamento do conselho de administração, ${ }^{, 306}$.

Na Inglaterra, CARVALHOSA demonstra que, dentro de sua esfera de competência, o administrador não está obrigado a acatar instruções recebidas do acionista, tampouco o acionista pode anular um ato regular de gestão praticado pela administração ${ }^{307}$.

Com relação aos Estados Unidos ${ }^{308}$, extraímos abaixo o $\$ 7.32$ do Model Business Corporation Act, que regula o acordo de acionistas (shareholders' agreement), em diversos estados norte-americanos (alguns importantes estados como Nova York, Califórnia e Texas estão sujeitos a outras legislações). De acordo com a alínea "e" do documento legal, temos que:

(e) An agreement authorized by this section that limits the discretion or powers of the board of directors shall relieve the directors of, and impose upon the person or persons in whom such discretion or powers are vested, liability for acts or omissions imposed by law on directors to the extent that the discretion or powers of the directors are limited by the agreement. ${ }^{309}$

Trata-se de interessante e justa fórmula a adotada pela legislação norte-americana. Como vemos, as partes possuem ampla liberdade para prever o conteúdo do

306 VERGUEIRO, Carlos Eduardo. Acordo de Acionistas e a Governança das Companhias. São Paulo: Quartier Latin, 2010, p. 168.

307 "É interessante, neste ponto, destacar o direito inglês, o qual, em decisão de 1906, declara que, quando os diretores atuam dentro dos poderes conferidos pelo estatuto, não estão obrigados a obedecer às decisões da assembleia geral, não podendo, em consequência, os acionistas majoritários anular uma decisão dos diretores. (...) (Gramophone and Typewriter Ltd. v. Stanley (1908) 2K.B. 89; Salmon v Quin and Axtens (1909) Ch. 311 (C.A.) on appeal (1909) A.C. 442; Alexander Ward v. Samyang Navigation Co. Ltd. (1975) 1 W.L.R. 673." (CARVALHOSA, Modesto. Comentários à lei das sociedades anônimas. v. 2. $5^{\text {a }}$ ed. São Paulo: Saraiva, 2011, p. 17)

${ }^{308}$ CARVALHOSA afirma que “(o)s acordos de acionistas costumam estabelecer a composição do conselho de administração e questões relacionadas a governança corporativa. Tanto a General Corporation Law of the State of Delaware (DGCL) quanto a New York Business Corporation Law (NYBCL) reconhecem a validade de um acordo entre dois ou mais acionistas, se ele for escrito e assinado por todos, e estabelecer o modo como serão exercidos os direitos políticos (DGCL tit. 8, §218(c) (2001); NYBCL § 620(a) (McKinney 2003)." (CARVAlHOSA, Modesto. Comentários à lei das sociedades anônimas. v. 2. $5^{\text {a }}$ ed. São Paulo: Saraiva, 2011, p. 232)

${ }^{309}$ Model Business Corporation Act, §7.32. 
"shareholders' agreement"; porém, caso ele limite a discricionariedade ou os poderes do "board", então aquele que recebeu tais competências será o responsável pela observância dos deveres atribuídos pela lei.

Conforme mencionamos acima, nosso sistema prevê justamente o oposto, à medida que limita expressamente os poderes e a discricionariedade dos administradores $\left(\S \S 8^{\circ}\right.$ e $9^{\circ}$ do art. 118, da LSA) e os mantém responsáveis no âmbito do dever fiduciário do art. 154, da LSA.

De qualquer forma, independentemente do diploma analisado, o "princípio da common law norte-americana é o de que 'os membros do conselho de administração não são servos dos acionistas majoritários', ou (...) servos para seguir diretrizes (...) que lhes sejam dadas pelos acionistas majoritários (Voeller v. Neilston Warehouse Co.) ${ }^{\text {„310. }}$.

Nesse sentido, a lição final de CUNHA (citando o trabalho de HAMILTON):

$\mathrm{Na}$ prática norte-americana, leciona Hamilton, existe absoluta independência dos membros do conselho: "Os acordos de acionistas que versam sobre assuntos de competência dos conselheiros são frequentemente mencionados pelas cortes em termos antagonísticos: são eles contrários às diretrizes públicas porque limitam a discricionariedade dos conselheiros e, em casos extremos, esterilizam o próprio conselho de administração. (...) $\mathrm{O}$ acordo de voto entre acionistas limita-se ao exercício de voto em matérias de competência dos acionistas, como a eleição de conselheiros, e deveria ser claramente apartado dos acordos que tendem a resolver assuntos de competência dos conselheiros. Esse último tipo de acordo levanta sérias questões de validade. ${ }^{311}$

${ }^{310}$ CARVAlHOSA, Modesto. Comentários à lei das sociedades anônimas. v.2. $5^{\mathrm{a}}$ ed. São Paulo: Saraiva, 2011 , p. 17.

${ }^{311}$ HAMILTON. The law of corporations. p. 279, apud, CUNHA, Rodrigo Ferraz Pimenta da. Estrutura de Interesses nas Sociedades Anônimas - Hierarquia e Conflitos. São Paulo: Quartier Latin, 2007, p. 322. Outro interessante precedente é mencionado por BOCATER e CAMARGO: "No precedente de 1934 envolvendo os acionistas dos 'Giants', famoso clube de baseball de Nova Iorque, decidiu-se que os acionistas podem, por óbvio, firmar acordos para eleger conselheiros. Não podem, entretanto, restringir o poder dos conselheiros de administrar os negócios da companhia, inclusive o poder de selecionar diretores ou de definir sua remuneração. (...) É importante enfatizar um dos fundamentos apontados no voto proferido pelo relator do caso: a de que a decisão então tomada era preferível a outra que levasse o tribunal a ter de decidir quanto aos motivos dos conselheiros para tomarem uma deliberação inerente ao exercício legal de suas atribuições. (...) A esfera de discricionaridade atribuída aos administradores não lhes pode ser subtraída, seja pelos acionistas, seja pelo Judiciário." (CAMARGO, João Laudo; BOCATER, Maria Isabel do Prado. Conselho de Administração: seu Fucionamento e Participação de Membros Indicados por Acionistas Minoritários e Preferencialistas. In LOBO, Jorge (Coord.). Reforma da Lei das Sociedades Anônimas. $2^{\mathrm{a}}$ ed. Rio de Janeiro: Forense, 2002, pp. 398-399) 


\section{VINCULAÇÃO DA ADMINISTRAÇÃO NOS GRUPOS SOCIETÁRIOS DE FATO E DE DIREITO}

Antes de expormos nossas conclusões, faremos breves comentários sobre a vinculação de administradores nos grupos societários de fato e de direito ${ }^{312}$.

Esse tema, por si só, permitiria uma nova dissertação, em vista dos diversos elementos envolvidos. O modelo jurídico societário dos grupos tem sido objeto de constante revisão acadêmica, especialmente pelo desuso dos grupos de direito e da carência de regulação sobre os grupos de fato.

O foco de nossa análise, no entanto, é a mera possibilidade jurídica de subordinar a administração de uma companhia controlada ao direcionamento do grupo.

Primeiramente, cumpre-nos diferenciar os grupos de fato e de direito. A LSA, no seu Capítulo XX (arts. 243 e ss.), prevê as regras relativas às sociedades coligadas, controladas e controladoras; no Capítulo XXI (arts. 265 e ss.), traz a disciplina específica dos grupos constituídos através de convenção grupal. Temos, assim, que primeiramente estão regulados os grupos de fato e, posteriormente, os grupos de direito.

Segundo a LSA, só existirá oficialmente um grupo de direito, quando uma sociedade controladora e suas controladas constituírem uma "convenção pela qual se obriguem a combinar recursos ou esforços para a realização dos respectivos objetos, ou a participar de atividades ou empreendimentos comuns" (art. 265), devendo a conveção ser arquivada no registro do comércio.

\footnotetext{
312 "Os grupos de sociedades surgiram como instrumentos da concentração empresarial e de dominação de mercados, e as primeiras leis que os regularam nos Estados Unidos, conhecidas como anti-trusts, eram de direito público e visavam a impedir a formação de monopólios ou oligopólios e a preservar a competitivade. (...) O grupo de sociedades surgiu no fim do Século XIX, quando o processo de concentração industrial conduziu à formação de empresas de grande escala e à propriedade de ações de uma companhia por outra, e não apenas por pessoas naturais. A princípio a concentração baseou-se no instituto do voting trust, a que se seguiram as incorporações e fusões, a criação de companhias holding e os grupos de sociedades. (...) No Brasil, os grupos de sociedades surgiram após a Segunda Guerra Mundial, com o processo de industrialização do País, difundindo-se, a partir de 1965, com a organização de conglomerados privados financeiros (e financeiros-comerciais-industriais), que tiveram origem na orientação adotada pela legislação dos mercados financeiros de exigir a especialização das sociedades que têm por objeto serviços próprios de instituições financeiras, de intermediação nos mercados de capital e seguros.” (VARGAS, Manoel. In BULHỖES PEDREIRA, José Luiz e LAMY FILHO, Alfredo (Coord.). Direito das Companhias. Vol. I. Rio de Janeiro: Forense, 2010, pp. 2.052-2.053)
} 
Fora de tais hipóteses, a lei fala em sociedades coligadas, controladoras e controladas (Capítulo XX), sem aludir a grupos, e sem admitir que cada uma dessas sociedades possa atuar no interesse de outra, ou submeter-se às diretivas emanadas de outra $^{313}$. Assim, o grupo de fato é formado a partir de uma relação de controle ou de coligação.

De acordo com a LSA, apenas aos grupos de direito (completamente escassos em nossa realidade empresarial) seria facultado uma sociedade privilegiar o interesse de outra sociedade do grupo, desde que assim previsto na convenção.

No grupo de fato, por sua vez, o modelo jurídico atual veda a subordinação do interesse social de sociedades controladas à orientação gerencial do grupo, a menos que mediante pagamento compensatório adequado, conforme previsão do art. 245, da LSA ${ }^{314}$.

Mesmo diante de tal restrição legal, a jurisprudência acabou reconhecendo o efeito cascata do acordo de acionistas sobre as sociedades controladas: "O acordo de acionistas firmado entre pessoas físicas e jurídicas controladoras de grupo de sociedades teria efeito 'cascata' sobre todas as sociedades do grupo"315.

\footnotetext{
${ }^{313}$ COMPARATO, Fábio Konder. Os Grupos Societários na Nova Lei de Sociedade por Ações. In Ensaios e Pareceres de Direito Empresarial. Rio de Janeiro: Forense, 1978, p. 200.

314 "Nos grupos societários de fato (...), o legislador reconheceu a possibilidade (...) de as sociedades, controladas, coligadas ou societariamente autônomas, atuarem de forma coordenada, mas, para tanto, ditou expressas condições a serem observadas pelos administradores das sociedades envolvidas. De forma expressa, proibiu que, exceção feita aos grupos de direito, possam as sociedades agrupadas atuar de forma subordinada aos interesses de uma delas (...)." (VON ADAMEK, Marcelo Vieira. Responsabilidade dos Administradores de S.A. e as Ações Correlatas. São Paulo: Saraiva, 2009, p. 157)

${ }^{315}$ Ap. 161.344-1/9. TJSP. $4^{\text {a }}$ Câmara Cível. Rel. Des. Ney Almada. Julgado em 26.11.1992. A doutrina endossou referida decisão judicial, vide os comentários de CARVALHOSA e EIZIRIK: (i) “(...) indiscutível que os acordos de controle firmados no âmbito das sociedades controladoras têm plena eficácia sobre suas controladas. Seria ineficaz o pacto de controle se pudesse ser entendido como restrito à própria controladora." (CARVALHOSA, Modesto. Comentários à lei das sociedades anônimas. v. 3. $5^{\text {a }}$ ed. São Paulo: Saraiva, 2011, p. 562); e (ii) "A lei societária, ao regular o poder de controle, admite a existência não só do controle direto, como também do controle indireto, isto é, aquela modalidade de poder própria de um grupo de sociedades, em que poder de controle deriva de relações societárias entre as companhias e é exercido através dos órgãos sociais de outra companhia. (...) Em vista disso, como o artigo 118 da lei societária passou a mencionar os acordos de acionistas para o exercício do poder de controle, fica claro que a eficácia do acordo estende-se a todas as modalidades nas quais o poder de controle pode se manifestar, inclusive, o controle indireto. Além disso, (...) a Lei n. 10.303/2001 também vinculou os administradores eleitos pelas partes às disposições dos acordos de acionistas, o que reafirma o entendimento de que estes estão aptos a produzir efeitos perante as sociedades controladas." (EIZIRIK, Nelson. Temas de Direito Societário. Rio de Janeiro: Renovar, 2005, pp. 37-38)
} 
Não queremos dizer, com isso, que o julgado infringiu a LSA, mas que legitimou faticamente, ainda mais, o chamado interesse social do grupo. Os acordos de acionistas são, em regra, estruturados e negociados com o foco no interesse do grupo ou da sociedade controladora, e não no interesse de cada sociedade controlada em si.

Se o objetivo do regime legal atual dos grupos de fato foi pensado para evitar a transferência de lucros ou resultados entre sociedades coligadas, controladoras e controladas, em prejuízo de eventuais minoritários de cada sociedade do grupo, o julgado acima escancarou a necessidade de revisão do modelo atual.

A disseminação dos grupos societários fez surgir uma crise no modelo societário clássico de regulação. Isso se deve ao fato de tal modelo basear-se na autonomia e soberania de cada sociedade, pelo próprio desenvolvimento do conceito de personalidade jurídica. Porém, os grupos trouxeram uma realidade econômica fática de submissão completa dessa autonomia à atividade econômica desenvolvida pelo grupo em si, i.e., o conceito jurídico de sociedade foi absorvido pelo conceito econômico de empresa. A crise é representada, portanto, na carência de regulação dessa unidade econômica.

Ao que nos interessa para este capítulo (vinculação da administração nos grupos societários), a nosso ver, tanto a crise do modelo atual de regulação dos grupos, quanto o julgado acima, dificultaram ainda mais a vida dos administradores das sociedades controladas. Eles faticamente estarão subordinados ao interesse do grupo, mas ainda assim preservarão o dever atribuído pelo art. 245, da LSA, de observar o interesse da companhia controlada. Trata-se de uma árdua missão ${ }^{316}$.

Por fim, destacamos estudo recente publicado por MUNHOZ sobre uma fundamentação jurídica capaz de permitir que controladores e administradores privilegiem o interesse do grupo de fato, sem incorrer nas hipóteses de responsabilização no âmbito dos arts. 117 e 245 , respectivamente, da LSA:

\footnotetext{
316 “(...) todas as decisões tomadas pelos acionistas controladores da sociedade participante do grupo de fato, bem como os atos praticados por seus administradores, devem ter por objetivo, exclusivamente, a consecução do interesse específico de tal companhia, conforme estabelecido nos arts. 117 e 154 da Lei das S.A." (EIZIRIK, Nelson. Independência dos administradores em relação ao acionista controlador. Relações entre companhias integrantes de grupo de fato. In Estudos de Direito Empresarial. São Paulo: Saraiva, 2010, p. 372)
} 
$\mathrm{O}$ art. $117, \S 1^{\circ}$, "a", da Lei das S.A., ao definir como abusivo o ato de o controlador favorecer outra sociedade, termina com a seguinte qualificação: "em prejuízo da participação dos acionistas minoritários nos lucros ou no acervo da companhia". Assim, se o favorecimento de outra sociedade não acarretar prejuízo da participação dos acionistas minoritários nos lucros sociais ou no acervo da companhia, não se poderá qualificar o ato do controlador como abusivo. A mesma orientação se observa no art. 245 , (...) o dispositivo é claro no sentido de que deve ocorrer "prejuízo da companhia". Excepciona, ainda, a vedação na hipótese de a operação favorecida com a outra sociedade observar "pagamento compensatório adequado". 317

${ }^{317}$ MUNHOZ, Eduardo Secchi. Estrutura de Governo dos Grupos Societários de Fato na Lei Brasileira. In CASTRO, Rodrigo Rocha Monteiro de; WARDE JÚNIOR, Walfrido Jorge; GUERREIRO, Carolina Dias Tavares (coord.). Direito Empresarial e Outros Estudos em Homenagem ao Professor José Alexandre Tavares Guerreiro. São Paulo: Quartier Latin, 2013, p. 288. O autor traz o seguinte exemplo: "o aval gratuito prestado pela sociedade controladora em operação de financiamento contratado pela controlada. A análise isolada dessa operação de financiamento poderia levar à conclusão de que causaria prejuízo à controladora; quando, porém, toma-se esse mesmo aval no contexto das diversas operações realizadas no âmbito do grupo, pode-se concluir que ele resultará em benefícios, na medida em que venha a permitir o financiamento de empreendimento da controlada e este se reverta em aumento dos lucros no futuro." (MUNHOZ, Eduardo Secchi. Estrutura de Governo dos Grupos Societários de Fato na Lei Brasileira. In CASTRO, Rodrigo Rocha Monteiro de; WARDE JÚNIOR, Walfrido Jorge; GUERREIRO, Carolina Dias Tavares (coord.). Direito Empresarial e Outros Estudos em Homenagem ao Professor José Alexandre Tavares Guerreiro. São Paulo: Quartier Latin, 2013, p. 289) 


\section{NOSSA VISÃO E CONCLUSÕES}

Como feito em outras oportunidades ao longo deste trabalho, de forma a melhor atender aos interesses dos diferentes perfis de leitores, divideremos nossa conclusão em duas perspectivas: (i) conclusão prática, representando nosso entendimento a partir do modelo posto (i.e., interpretação do que existe na realidade); e (ii) conclusão ideológica, refletindo nossa visão de um modelo ideal a ser perseguido (i.e., eventuais acréscimos ou revisões ao modelo existente).

\subsection{Conclusão prática}

O legislador de 2001 poderia ter esclarecido melhor a inserção dos $\S \S 8^{\circ}$ e $9^{\circ}$ ao art. 118 da LSA, a fim de evitar interpretações contraditórias sobre seu potencial entrechoque com os demais dispositivos da LSA (notadamente arts. 154 e 139), já que, como pudemos observar, inexiste consenso na jurisprudência (que possui julgados nos dois sentidos) e na doutrina (também extremamente dividida).

De todo modo, a nosso ver, a vinculação dos administradores aos termos dos acordos de acionistas passou a ser uma realidade imposta pelo legislador a partir de $2001 \mathrm{e}$ amplamente recepcionada pela prática empresarial (vide os dados empíricos constantes do Subcapítulo 6.4).

Porém, essa vinculação é limitada. Isso porque ela precisa ser sistematicamente interpretada com os demais dispositivos da LSA, a qual prevê pelo menos dois dispositivos limitadores da vinculação, quais sejam:

(i) o poder (dever) finalístico atribuído ao administrador, de privilegiar o interesse da companhia (institucionalista, a nosso ver), previsto no art. 154, da LSA; e

(ii) a indelegabilidade das funções atribuídas pela lei e, frise-se, pelo estatuto a outros órgãos sociais, princípio este ao qual se submete a própria assembleia geral, que é atualmente concebida como relativa e funcionalmente soberana em relação aos demais 
órgãos (i.e., sua posição hierarquicamente superior não lhe permite modificar ou avocar competências que a própria lei atribuiu a outro órgão social).

Entre as competências do conselho de administração previstas no art. 142 da LSA, entendemos serem privativas e, portanto, não passíveis de vinculação ao acordo de acionistas, aquelas listadas nos incisos II (eleger e destituir os diretores da companhia e fixar-lhes as atribuições, observado o que a respeito dispuser o estatuto), III (fiscalizar a gestão dos diretores, examinar, a qualquer tempo, os livros e papéis da companhia, solicitar informações sobre contratos celebrados ou em via de celebração, e quaisquer outros atos), IV (convocar a assembléia-geral quando julgar conveniente, ou no caso do artigo 132), V (manifestar-se sobre o relatório da administração e as contas da diretoria), e IX (escolher e destituir os auditores independentes, se houver).

As competências estatutariamente atribuídas aos administradores também não são suscetíveis de vinculação, a menos que o próprio texto do estatuto preveja exceções ou, obviamente, seja modificado pela assembleia geral de acionistas.

Entendemos ainda que, independentemente de nossa posição ideológica acerca da vinculação, também são aplicáveis aos acordos de minoria os mecanismos previstos nos $\S \S$ $8^{\circ}$ e $9^{\circ}$ do art. 118, da LSA, uma vez que a lei não restringiu sua incidência aos acordos de controle.

Por fim, destacamos que, embora a lei confira às duas fontes de poder (acionista controlador e administração) o dever de observar o interesse da companhia e a vinculação, em princípio, não isente a administração de suas responsabilidades legais, na prática, a vinculação pode acarretar, sim, um tratamento diferenciado de responsabilidades de ambos os poderes.

Isso se deve ao fato de a lei permitir tanto aos acionistas quanto aos administradores que tiverem seu voto desconsiderado pelo presidente da mesa que fizer uso dos $\S \S 8^{\circ}$ e $9^{\circ}$ do art. 118, da LSA, consignar em ata a motivação de sua tentativa de voto, como forma de mitigar sua responsabilidade. Da mesma forma, incorrerá em responsabilidades adicionais o acionista (ou membro do conselho) que votar com as ações do acionista (ou pelo 
conselheiro) ausente, omisso ou inadimplente (este último não previsto no $\S 9^{\circ}$, mas aceito pela doutrina), caso tal voto seja contrário ao interesse da companhia.

\subsection{Conclusão ideológica}

Do ponto de vista ideológico, a nosso ver, a vinculação não é favorável.

Vincular o administrador ao acordo de acionistas significa concentrar o poder em uma única fonte. E o excesso de poder, em regra, gera abusos e consequente descumprimento das normas ${ }^{318}$.

Os problemas de agência das duas possíveis estruturas de propriedade acionária reforçam essa constatação, i.e., o exercício do poder exclusivamente pelo administrador nos mercados dispersos, e pelo controlador nos concentrados não é satisfatório ${ }^{319}$.

Como vimos, a solução para os conflitos de agência tem sido o efetivo monitoramento do poder prevalecente. No ambiente de dispersão, os administradores têm sido cada vez mais monitorados pela presença de acionistas estratégicos (tais como fundos de private equity e fundos de pensão) e, na estrutura concentrada, a doutrina tem defendido a redefinição do papel do conselheiro independente como órgão capaz de efetivamente monitorar a atuação do controlador.

Percebemos, assim, uma convergência funcional nos dois sistemas de combate ao conflito de agência, sendo que nenhuma delas passa ou cogita a vinculação ou a concentração de poderes tal qual legitimado por nossa lei.

\footnotetext{
318 "O entendimento corrente é o de que o excesso de poder é maléfico. E a tão bem desenhada estrutura orgânica da companhia não carece de um instrumento como este imposto pelos $\S \S 8^{\circ}$ e $9^{\circ}$. “(...) em situações de grande concentração de poder, a tendência de abuso desse poder (e, portanto, de descumprimento das regras de comportamento) é algo natural. Essa constatação não é nova. Trata-se do fato, hoje bem reconhecido pela teoria econômica, de que a racionalidade de atuação dos agentes econômicos os leva naturalmente ao abuso." (SALOMÃO FILHO, Calixto. O Novo Direito Societário. $4^{\mathrm{a}}$ ed. São Paulo: Malheiros, 2011, p. 56)

319 "Trata-se da comum ligação a um problema de poder - poder descontrolado e não fiscalizado do administrador no primeiro caso (muito comum na realidade americana) e poder descontrolado do controlador no segundo (muito comum na realidade brasileira)." (SALOMÃO FILHO, Calixto. O Novo Direito Societário. $4^{a}$ ed. São Paulo: Malheiros, 2011, p. 58)
} 
O controlador é faticamente o árbitro do interesse social e não há problema algum nisso. Como detentor da maior parcela de capital e, portanto, ciente dos riscos assumidos, tende a, em situações normais, zelar muito mais pelo interesse da companhia que apostou dinheiro, do que os administradores que são apenas por ela remunerados (e, por esse motivo, mais suscetíveis a privilegiar a preservação de seu cargo e o aumento de sua remuneração).

Não por outro motivo, a doutrina estrangeira é praticamente unânime em reconhecer que a concentração de capital representa um útil e eficiente instrumento de mitigação do custo de agência.

Assim, reiteramos que o controlador pode e deve continuar a ser o principal árbitro do interesse social. Porém, vincular a administração, da forma permitida pelos $\S \S 8^{\circ}$ e $9^{\circ}$ do art. 118 da LSA, abre espaço para a legitimação da extração de benefícios privados de controle, dificultando e muito o monitoramento de sua atuação.

Pela natureza institucional da companhia e pelos valores constitucionais de função social da propriedade e de proteção à poupança popular, é fundamental que o controlador seja, ao menos, efetivamente monitorado, a fim de que não pratique desvios do patrimônio da companhia e, assim, prejudique minorias e demais stakeholders.

Nesse sentido, a remodelagem do papel do conselheiro independente (conforme sugerimos ao final do Capítulo $\mathrm{V}$ - especialmente o impedimento de o acionista controlador votar na sua eventual destituição deliberada em assembleia) serviria de principal meio de monitoramento do acionista controlador.

Entendemos que, somente assim, a companhia teria seu interesse institucional devidamente observado, i.e., fontes de poder equilibradas e meios eficientes de combate ao eventual conflito instaurado entre elas. 


\section{BIBLIOGRAFIA}

A. SHLEIFER E. R. VISHNY. A survey of corporate governance. Journal of Finance vol. 52, n. 2, 1997, p. 737-783.

A. SILVEIRA. Governança corporativa e estrutura de propriedade determinantes $e$ relação com o desempenho das empresas no Brasil. Tese de Doutorado. Faculdade de Economia, Administração e Contabilidade da Universidade de São Paulo, 2004.

A. DYCK e L. ZINGALES. Private Benefits of Control: An International Comparison. Harvard Law School 535, 2001.

ABREU, Jorge Manoel Coutinho de. Governança das sociedades comerciais. $2^{\circ}$. ed. Coimbra: Almedina, 2010

AKERLOFF, George, The market for lemmons: qualitative uncertainty and the market mechanism. In Wiener Katz, Avey, Foundations of the economic approach to Law, New York, Foundation Press, 1998.

AMERICAN LAW INSTITUTE. Principles of Corporate governance: Analysis and Recommendations. v. I, St. Paul: American Law Institute Publishers, 1994, p. 284, seção $5.05 b$.

ARAGÃO, Paulo Cezar. A Disciplina do Acordo de Acionistas na Reforma da Lei das Sociedades por Ações (Lei $n^{\circ}$ 10.303, de 2001). In Jorge Lobo (Coord.). Reforma da Lei das Sociedades Anônimas - Inovações e Questões Controvertidas da Lei n ${ }^{\mathbf{o}} 10.303$, de 31.10.2001. Rio de Janeiro: Forense, 2002, p. 373.

ASCARELlI, Tullio. Problemas das sociedades anônimas e direito comparado. São Paulo: Saraiva, 1945. 
ASQUINI, Alberto. Perfis da Empresa. Tradução de Fabio Konder Comparato. In Revista de Direito Mercantil, Industrial, Econômico e Financeiro. n . 104. São Paulo: Malheiros, pp. 109-126.

BAIRD, Douglas - Gertner, Robert - Picker, Randal. Game theory and the law. Cambridge, Massachussets and London, Harvard University Press, 1994.

BÁRBARA LEVY, Maria; NEUHAUS, Paulo (Coord.). Economia brasileira: uma visão histórica. Rio de Janeiro: Campus, 1980.

BARBI FILHO, Celso. Acordo de Acionistas: Panorama Atual do Instituto no Direito Brasileiro e Propostas para a Reforma de sua Disciplina Legal. In Revista de Direito Mercantil, Industrial, Econômico e Financeiro. n 121. São Paulo: Malheiros, 2001, p. 3055 . . Acordo de Acionistas. Belo Horizonte: Del Rey, 1993.

BARÉM LEITE, Leonardo. Governança Corporativa - Considerações sobre sua Aplicação no Brasil (Das Limitadas às Sociedades Anônimas de Capital Pulverizado). In CASTRO, Rodrigo R. Monteiro de; MOURA AZEVEDO, Luis André N. (Coord.). Poder de Controle e Outros Temas de Direito Societário e Mercado de Capitais. São Paulo: Quartier Latin, 2010, pp. 504-528.

BARRETO, Celso de Albuquerque. Acordo de Acionistas. Rio de Janeiro: Forense, 1982, p. 73.

BARRETO FILHO, Oscar. Estrutura administrativa das sociedades anônimas. In Revista de Direito Mercantil, Industrial, Econômico e Financeiro. nº 24. São Paulo: Malheiros, pp. $65-74$.

Síntese da Evolução Histórica do Direito Comercial Brasileiro. In Revista de Direito Mercantil, Industrial, Econômico e Financeiro. $n^{\circ}$ 24. São Paulo: Malheiros, pp. 23-27. 
BEBCHUCK, L. A.; ROE, M. J. A theory of path dependency in corporate governance and ownership. Stanford Law Review vol. 52, 1999, p. 775-808

BERLE, Adolf; MEANS, Gardiner. Modern Corporation and Private Property. $10^{\mathrm{a}}$ ed. Londres: Transaction Pub, 2010.

BERTOLDI, Marcelo M. Acordo de acionistas. São Paulo: RT, 2005. . Reforma da Lei das Sociedades Anônimas. São Paulo: RT, 2002.

BLACK, Henry Campbell. Black's Law Dictionary. St. Paul, Minn West Publishing Co., 1968.

BLOCK, Denis J.; BARTON, Nancy E.; and RADIN, Stephen A. The Business Judgement Rule - Fiduciary Duties or Corporate Directors. New York: Aspen Law and Business, 1998.

BORBA, José Edwaldo Tavares. Direito Societário. 11 ed. Rio de Janeiro: Renovar, 2008.

BULGARELLI, Waldírio. Comentários à lei das sociedades anônimas. São Paulo: Saraiva, 1978.

. Manual das sociedades anônimas. $6^{\text {a }}$ ed. São Paulo: Atlas, 1991.

Apontamentos sobre a responsabilidade dos administradores das companhias. In Revista de Direito Mercantil, Industrial, Econômico e Financeiro. $\mathrm{n}^{\mathrm{o}} 50$. São Paulo: Malheiros, p. 75.

Validade de Disposições de Acordo de Acionistas de Votarem em Bloco, Assegurando a Política Gerencial Única e Necessária. In Revista de Direito Mercantil, Industrial, Econômico e Financeiro. no 123. São Paulo: Malheiros, p. 185.

BULHÕES PEDREIRA, José Luiz; LAMY FILHO, Alfredo. Direito das Companhias. Volumes I e II. Rio de Janeiro: Forense, 2010. 
CALABRESI, Guido. Some Thoughts on Risk Distribution and the Law of Torts, Yale Law Journal vol. 70, 1969, p. 499.

CALERO, Fernando Sanchez. "Instituciones de Derecho Mercantil”, 1994, tomo IV.

CAMARGO, João Laudo e BOCATER, Maria Isabel do Prado. Conselho de Administração: seu Funcionamento e Participação de Membros Indicados por Acionistas Minoritários e Preferencialistas. In: Jorge Lobo (Coord.). Reforma da Lei das Sociedades Anônimas - Inovações e Questões Controvertidas da Lei 10.303, de 31.10.2001. Rio de Janeiro: Forense, 2002.

CAMPOS, Luiz Antonio de Sampaio. Conselho de Administração e Diretoria. In: Alfredo Lamy Filho e José Luiz Bulhões Pedreira (Coord.) Direito das Companhias. v. I, Rio de Janeiro: Forense, 2009, p. 1.124.

CARMO, Eduardo Sousa. Relações Jurídicas na Administração das Sociedades Anônimas. Rio de Janeiro: Aide, 1988, p. 25.

Cartilha de Governança Corporativa (2002) da Comissão de Valores Mobiliários - CVM.

CARVALHO, Ney O. O Encilhamento: anatomia de uma bolha brasileira (em português). São Paulo: Bovespa, 2004.

CARVALHO DE MENDONÇA, José Xavier. Tratado de direito comerccial brasileiro. $\mathrm{v}$. 3. $5^{\circ}$ ed. atual. por Achilles Bevilaqua e Roberto Carvalho de Mendonça. Rio de Janeiro: Freitas Bastos, 1954.

CARVALHOSA, Modesto. Comentários à lei das sociedades anônimas. vols. 1 a $5.5^{\mathrm{a}}$ ed. São Paulo: Saraiva, 2011.

Responsabilidade civil de administradores e de acionistas controladores perante a Lei das S/A. RT 699/36-43. 
Responsabilidade civil dos administradores das companhias abertas.

In Revista de Direito Mercantil, Industrial, Econômico e Financeiro. no 49. São Paulo: Malheiros, pp. 14-20.

Acordo de Acionistas Regulando o Exercício do Poder de Controle. In: Estudos e Pareceres. São Paulo: Saraiva, 2010.

. Acordo de Acionistas. São Paulo: Saraiva, 2011.

- A Vinculação dos Administradores ao Acordo de Controle. In WALD, Arnoldo; GONÇALVES, Fernando; SOARES DE CASTRO, Moema Augusta (Coord.) Sociedades Anônimas e Mercado de Capitais. Homenagem ao Prof. Osmar Brina Corrêa-Lima. São Paulo: Quartier Latin, 2011. pp. 41-46

; EIZIRIK, Nelson. A nova Lei das S/A. São Paulo: Saraiva, 2002.

; . Independência dos administradores em relação ao acionista controlador. Relações entre companhias integrantes de grupo de fato. In Estudos de Direito Empresarial. São Paulo: Saraiva, 2010. pp. 362-377.

CASTRO, Rodrigo R. Monteiro de. Concorrência Legislativa em Matéria Societária: um Possível Instrumento de Desenvolvimento Econômico e Social. In CASTRO, Rodrigo R. Monteiro de; MOURA AZEVEDO, Luis André N. (Coord.). Poder de Controle e Outros Temas de Direito Societário e Mercado de Capitais. São Paulo: Quartier Latin, 2010, pp. $532-556$.

. Controle Gerencial. São Paulo: Quartier Latin, 2010.

CARY, Willian L. and EISENBERG, Melvin Aron. Cases and Materials on Corporations. $6^{\text {th }}$ edition, New York: The Foundation Press, 1988, p. 349.

CEREZETTI, S. C. N. Administradores Independentes e Independência dos Administradores. In Temas de Direito Societário e Empresarial Contemporâneos - Liber 
Amicorum Prof. Erasmo V. A. Novaes e França. São Paulo: Malheiros Editores, 2011, p. 575-593.

CLARK, Robert C. Corporate Law. Boston: Little, Brown and Company, 1986.

COASE, Ronald. The Nature of the firm, The Firm, The Market and the Law, Chicago: University of Chicago Press, 1990.

The Problem of Social Cost, Journal of Law and Economics vol. 3, 1960.

Código de Melhores Práticas de Governança Corporativa (1999) do Instituto Brasileiro de Governança Corporativa - IBGC.

COMPARATO, Fábio Konder; SALOMÃO FILHO, Calixto. O poder de controle na sociedade anônima. $5^{\mathrm{a}}$ ed. Rio de Janeiro: Forense, 2008. . Novos ensaios e pareceres de direito empresarial. Rio de Janeiro:

Forense, 1981. . Aspectos Jurídicos da Macro-Empresa. São Paulo: RT, 1970.

- Obrigações de Meios, de Resultado e de Garantia in Ensaios e Pareceres de Direito Empresarial. Rio de Janeiro: Forense, 1983.

. Eleição de diretores em companhia aberta. Validade e eficácia de reuniões do conselho de administração de sociedade anônima. Quorum deliberativo em assembleias gerais de companhia aberta. In Direito Empresarial - Estudos e Pareceres, p. 186

CORRÊA DE OLIVEIRA, José Lamartine. A Dupla Crise da Pessoa Jurídica. São Paulo: Saraiva, 1979. 
CUNHA, Rodrigo Ferraz Pimenta da. Estrutura de Interesses nas Sociedades Anônimas Hierarquia e Conflitos. São Paulo: Quartier Latin, 2007.

EASTERBROOK, Frank - FISCHEL, Daniel, The economic structure of corporate law, Harvard University Press, Cambridge, Massachussets and London, 1991.

EIZIRIK, Nelson. Aspectos modernos do direito societário. Rio de Janeiro: Renovar, 1992. Sociedades Anônimas: jurisprudência, 2 ts. Rio de Janeiro: Renovar, 2000. . Temas de Direito Societário. Rio de Janeiro: Renovar, 2005.

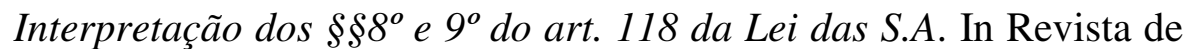
Direito Mercantil, Industrial, Econômico e Financeiro. n 139. São Paulo: Malheiros, 2005, p. 155.

Questões de Direito Societário e Mercado de Capitais. Rio de Janeiro: Forense, 1987.

Acordo de Acionistas - Arquivameto na Sede Social - Vinculaão dos Administradores e de Sociedade Controlada. In Revista de Direito Mercantil, Industrial, Econômico e Financeiro. n 129. São Paulo: Malheiros, 2003, p. 45.

Lei das S.A. Comentada. Volumes I e II. São Paulo: Quartier Latin, 2011.

Acordo de acionistas regulando o exercício do poder de controle. Interpretação dos $\$ 8^{\circ}$ e $9^{\circ}$ do art. 118 da Lei das S.A. In Estudos de Direito Empresarial. São Paulo: Saraiva, 2010. pp. 362-377.

; GAAL, Ariádna B.; PARENTE, Flávia; e HENRIQUES, Marcus de Freitas. Mercado de Capitais - Regime Jurídico. $3^{\text {a }}$ ed. Rio de Janeiro: Renovar, 2011. 
ELSON, Alex. Shareholders Agreement, a Shield for Minority Shareholders of Close Corporations. American Bar Association, 1967.

ENGISH, Karl, Introdução ao Pensamento Jurídico, $8^{\mathrm{a}}$ ed., Lisboa, Fundação Calouste Gulbekian, 2001.

FARIA, José Eduardo. O Direito na Economia Globalizada. São Paulo: Malheiros, 1993.

FRANCO, Vera Helena de Melo; SZTAJN, Rachel. Direito Empresarial II: sociedade anônima, mercado de valores mobiliários. $2^{\circ}$ ed. ver. atual. e ampl. São Paulo: Revista dos Tribunais, 2009

FRANÇA, Erasmo Valladão Azevedo e Novaes. Conflitos de interesses nas assembléias de S.A. São Paulo: Malheiros, 1993.

Apontamentos sobre a invalidade das deliberações conexas das companhias. In Revista de Direito Mercantil, Industrial, Econômico e Financeiro. $\mathrm{n}^{\mathrm{o}} 122$. São Paulo: Malheiros, pp. 19-35.

Conflito de interesses: formal ou substancial? Nova decisão da CVM sobre a questão. In Revista de Direito Mercantil, Industrial, Econômico e Financeiro. $\mathrm{n}^{\circ}$ 128. São Paulo: Malheiros, pp. 225-262.

Invalidade das deliberações de assembléia de $S$ A. São Paulo: Malheiros. 1999. n.7.

Dever de Informar dos Administradores de Companhias Abertas. Inexistência de Submissão ao Acionista Controlador. In Temas de Direito Societário, Falimentar e Teoria da Empresa. São Paulo: Malheiros, 2009.

FRONTINI, Paulo Salvador. Responsabilidade dos administradores em face da nova Lei das Sociedades por Ações. In Revista de Direito Mercantil, Industrial, Econômico e Financeiro. $n^{\circ}$ 26. São Paulo: Malheiros, pp. 35-49. 
GALGANO, Francesco. Lex Mercatoria. Tradução de Erasmo Valadão A. e N. França. In Revista de Direito Mercantil, Industrial, Econômico e Financeiro. $n^{\circ}$ 129. São Paulo: Malheiros, pp. 224-228.

GILSON, R. Controlling shareholders and corporate governance: complicating the comparative taxonomy. ECGI Working Paper No. 49. 205, p. 12. Disponível in <http://ssrn.com/abstract=784744> Último acesso em 18.01.2014.

.; Corporate governance and economic efficiency: when do institutions matter? Washington University Law Quarterly 74, 1996, p. 327.

; GORDON, J. Controlling controlling shareholders. In University of Pennsylvania Law Review 152, 2003.

GOMES, Orlando. Responsabilidade dos administradores de sociedades por ações. In Revista de Direito Mercantil, Industrial, Econômico e Financeiro. n ${ }^{\circ}$ 8. São Paulo: Malheiros, pp. 11-16.

. Contratos. Rio de Janeiro: Forense, 1953.

. A Crise do Direito. São Paulo: M. Limonad, 1955.

GORGA, Érica; GELMAN, Marina. O Esvaziamento Crescente do Conselho de Administração como Efeito da Vinculação de seu Voto a Acordos de Acionistas no Brasil. Prêmio IBGC Itaú Academia e Imprensa, 2012.

GOWER and DAVIES. Principles of Modern Company Law. Londres: Sweet \& Maxwell. 2008.

GRAU, Eros Roberto. A Ordem Econômica na Constituição de 1988. 2 ed. São Paulo: Ed. RT, 1991. 
GUERREIRO, José Alexandre Tavares. Responsabilidade dos administradores de sociedades anônimas. In Revista de Direito Mercantil, Industrial, Econômico e Financeiro. $n^{\circ}$ 42. São Paulo: Malheiros, pp. 69-88.

HAMILTON, Robert W. The Law of Corporations. 5 e.d. West Group, 2000.

HANSMANN, Henry e KRAAKMAN, Reinier. The End of History for Corporate Law. Georgetown Law Journal 89. 2001, pp. 439 e seguintes.

Reflections on the End of History for Corporate Law. August 2011. Forthcoming in Abdul Rasheed and Toru Yoshikawa, Eds. Convergence Corporate Governance: Promise and Prospects. Palgrave-MacMillan 2012, p. 10-11. Disponível em <http://ssrn.com/abstract=2095419> Último acesso em 18.01.2014

HENN, Harry G. and ALEXANDER, John R. Laws of Corporations. Sr. Paul, Minn: West Publishing Co., p. 518.

HOPT, J. Klaus; KANDA, Hideki; ROE, J. Mark; WYMEERSCH, Eddy; PRIGGE, Stefan. Comparative Corporate Governance - The State of Art and Emerging Research. New York: Oxford University Press, 1998.

HOUAISS, e VILAR, M. S. Dicionário Houaiss da Língua Portuguesa. Rio de Janeiro: Objetiva, 2012.

JAEGER, Pier Giusto. L’Interesse Sociale, Milano, Giuffré, 1972.

JENSEN, Michael; e MECKLING, Willian. Theory of the Firm Managerial Behavior, Agency Costs and Ownership Structure, in Journal of Financial Economics vol. 3, 1976.

KAPLOW E SHAVELL. Fairness versus welfare. Harvard Law Review, vol. 114, n 4, 2001, p. 961-1388.

The conflict between notions of fairness and the Pareto principle. American Law and Economics Review, vol. 1, n 1 e 2, 1999, p. 63-77. 
KLEIN, Willian; GULATI, Mitu; e ZOLT, Eric. Connected Contracts, in University of California Law Review.

KNEPPER, Willian E. Liability of Corporate Officers and Directors. Columbus: The Allen Smith Company, 1978.

KRAAKMAN, Reiner R.; DAVIES, Paul; HANSMANN, Henry; HERTIG, Gerard; HOPT, Klaus J.; KANDA, Hideki; ROCK, Edward B. The Anatomy of Corporate Law - A Comparative and Functional Approach. Oxford: Oxford University Press, 2007.

L. ZINGALES. The value of the voting right: a study of the Milan stock exchange experience. The Review of Financial Studies 7, p. 125-148.

LA PORTA, LOPEZ-DE-SILANES e SHLEIFER. Corporate ownership around the world. Journal of Finance 54, 1999, p. 471-518.

protection and corporate governance. Journal of Financial Economics 58.1, 2000, p. 125.

LACERDA, J. C. Sampaio. Comentários à Lei de Sociedades Anônimas. São Paulo: Saraiva, 1978.

LARENZ, Karl. Metodologia da Ciência do Direito. Tradução de José Lamego. 3 ed. Lisboa: Fundação Calouste Gulbenkian, 1997.

LAMY FILHO, Alfredo. Acordo de Acionistas - Observância dos Administradores aos Termos do Acordo. In Temas de S.A., São Paulo: Renovar, 2007, p. 323.

A Lei das S.A.: (pressupostos, elaboração, aplicação). 2 ed. Rio de Janeiro: Renovar, 1996.

LARENZ, Karl, Metodologia da Ciência do Direito, $3^{\mathrm{a}}$ ed., Lisboa, Fundação Calouste Gulbekian, 1997. 
LATTIN, Norman D. The Law of Corporations, Mineola, New York. Foundation Press Inc., 1971

LAZZARESCHI NETO, Alfredo Sérgio. Lei das Sociedades por Ações Anotada. São Paulo: Saraiva, 2012.

LEÃES, Luiz Gastão de Barros. Estudos e Pareceres sobre Sociedades Anônimas. São Paulo: Revista dos Tribunais, 1989.

Efeitos sobre terceiros dos acordos de acionistas. In

Pareceres. v. II. São Paulo: Singular, 2004.

LOBO, Jorge. Direito dos Acionistas. Rio de Janeiro: Elsevier, 2011.

LOSS, Louis. Securities Regulation. Boston, Little, Brown and Company, 1961.

LUCENA, José Waldecy. Das Sociedades Anônimas - Comentários à Lei (arts. $1^{o}$ a 120). v. I. Rio de Janeiro: Renovar, 2009.

M. ROE e L. BEBCHUK. A theory of path dependency in corporate governance and ownership. Stanford Law Review vol. 52, 1999, p. 775-808.

MACEY, Jonathan R. An Economic Analysis of the Various Rationales for Making Shareholders the Exclusive Beneficiaries of Corporate Fiduciary Duties. Stetson Law Review, Vol. XXI, 1991-1992, 23-44.

MAGALHÃES, Vânia Patrícia Filipe. A conduta dos administradores das sociedades anónimas: deveres gerais e interesse social. In Revista de Direito das Sociedades. Ano I. número 2. Coimbra: Almedina, 2009.

MAXIMILIANO, Carlos. Hermenêutica e Aplicação do Direito. Rio de Janeiro: Forense, 2011. 
MELLO FRANCO, Vera Helena de. Manual de direito comercial. $3^{\text {a }}$ ed. São Paulo: RT, 2009, v. 1 . ; SZTAJN, Rachel. Manual de direito comercial. $2^{\mathrm{a}}$ ed. São Paulo: RT, 2009, v. 2.

MIRANDA, Pontes de. Tratado de Direito Privado. t. L, 3 ed. São Paulo: Revista dos Tribunais, 1984.

MORCK, RANDALL, SHLEIFER E VISHNY. Management ownership and market valuation: an empirical analysis. Journal of Financial Economics 20, 1988, p. 293-316.

MOURA AZEVEDO, Luís André N. de. Ativismo dos Investidores Institucionais e Poder de Controle nas Companhias Abertas de Capital Pulverizado Brasileiras. In CASTRO, Rodrigo R. Monteiro de; MOURA AZEVEDO, Luis André N. (Coord.). Poder de Controle e Outros Temas de Direito Societário e Mercado de Capitais. São Paulo: Quartier Latin, 2010, pp. 217-258.

MUNHOZ, Eduardo Secchi. Empresa contemporânea e direito societário - poder de controle e grupos de sociedades. São Paulo: Juarez de Oliveira, 2002.

Desafios do Direito Societário da Companhia Aberta: Avaliação dos Sistemas de Controle Diluído e Concentrado. In Direito Societário: Desafios Atuais. Obra coordenada por Rodrigo Monteiro de Castro e Leandro Santos de Aragão. São Paulo: Quartier Latin, 2009.

- Transferência de Controle nas Companhias sem Controlador Majoritário. In CASTRO, Rodrigo R. Monteiro de; MOURA AZEVEDO, Luis André N. (Coord.). Poder de Controle e Outros Temas de Direito Societário e Mercado de Capitais. São Paulo: Quartier Latin, 2010, pp. 285-319.

Transferência de Controle nos Sistemas de Controle Concentrado e de Capital Disperso: Eficiências e Ineficiências. In Temas de Direito Societário e 
Empresarial Contemporâneos. Obra coordenada por Marcelo Vieira Von Adamek. São Paulo: Malheiros, 2011.

Quem deve comandar a companhia? Alocação do poder empresarial: sistema de freios e contrapesos. In Estudos em Homenagem a Modesto Carvalhosa. São Paulo: Saraiva, 2012. pp. 505-517.

Estrutura de Governo dos Grupos Societários de Fato na Lei Brasileira. In CASTRO, Rodrigo Rocha Monteiro de; WARDE JÚNIOR, Walfrido Jorge; GUERREIRO, Carolina Dias Tavares (coord.). Direito Empresarial e Outros Estudos em Homenagem ao Professor José Alexandre Tavares Guerreiro. São Paulo: Quartier Latin, 2013.

OIOLI, Erik; VEIGA, Marcelo Godke. Convergência e Divergência em Sistemas de Mercados de Capitais: O Caso Brasileiro. In CASTRO, Rodrigo R. Monteiro de; MOURA AZEVEDO, Luis André N. (Coord.). Poder de Controle e Outros Temas de Direito Societário e Mercado de Capitais. São Paulo: Quartier Latin, 2010, pp. 338-355.

PARENTE, Flávia. $O$ dever de diligência dos administradores de sociedades anônimas. Rio de Janeiro: Renovar, 2005.

PATELLA, Laura Amaral; BORES, Leandro Vilarinho; BERNARDES, Lucas Petri; AZEVEDO, Luís André Negrelli de Moura. Deveres Fiduciários dos Administradores. Vinculação dos Administradores. In Mercado de Capitais Brasileiro: Doutrina, Cases e Materials. São Paulo: Quartier Latin, 2012.

PATROCÍNIO, Daniel Moreira do. Autotutela do Acordo de Acionistas - Novo Regime Estabelecido pela Lei 10.303/2001. In Revista de Direito Mercantil, Industrial, Econômico e Financeiro. no 135. São Paulo: Malheiros, 2004, p. 194.

PEDREIRA, José Luiz Bulhões. Acordo de Acionistas sobre Controle de Grupo de Sociedades. Validade de Estipulação de que os Membros do Conselho de Administração de Controlada Devem Votar em Bloco Segundo Orientação Definida pelo Grupo 
Controlador. In Revista de Direito Bancário, do Mercado de Capitais e da Arbitragem. $\mathrm{n}^{\circ}$ 15. São Paulo: Revista dos Tribunais, p. 226.

PEREIRA, Caio Mário da Silva. Instituições de Direito Civil. v. I e II. Rio de Janeiro: Forense, 1966.

Princípios de Governança Corporativa (1998) da Organização do Comércio e Desenvolvimento Econômico - OCDE.

PONTES DE MIRANDA, Francisco Cavalcanti. Tratado de direito privado. ts. 12, 24, 25, 50, $2^{\text {a }}$ ed. São Paulo: RT, 1959.

POSNER, Richard. Economic Analysis of Law, $5^{\circ}$ ed., New York, Aspen Law \& Business, 1998.

R. OKIMURA. Estrutura de propriedade, governança corporativa, valor e desempenho das empresas no Brasil. Dissertação de Mestrado. Faculdade de Economia, Administração e Contabilidade da Universidade de São Paulo, 2003.

RAMOS, Felipe de Freitas. Responsabilidade dos signatários de acordo de voto no regime da Lei 10.303/2001. In Revista de Direito Mercantil, Industrial, Econômico e Financeiro. $\mathrm{n}^{\mathrm{o}}$ 125. São Paulo: Malheiros, p. 45.

RATHENAU, Walter. Do Sistema Acionário - Uma Análise Negocial.. In Revista de Direito Mercantil, Industrial, Econômico e Financeiro. n 128. São Paulo: Malheiros, pp. 224-262.

REALE, Miguel. Estudos Preliminares de Direito. $27^{\circ}$ ed.. São Paulo: Saraiva, 2003. O Direito como Experiência. $2^{\circ}$ ed.. São Paulo: Saraiva, 1992.

REQUIÃO, Rubens. Curso de direito comercial. v. 2. $25^{\circ}$ ed. atual. por Rubens Edmundo Requião. São Paulo: Saraiva, 2003. 
RIBEIRO, Renato Ventura. Dever de Diligência dos Administradores de Sociedades. São Paulo: Quartier Latin, 2006.

Direito de Voto nas Sociedades Anônimas. São Paulo:

Quartier Latin, 2009.

ROE, Mark J. Political Determinants of Corporate Governance: Political Context, Corporate Impact. Oxford University Press, 2006.

ROCHA, João Luiz Coelho da. Os Compromissos de Voto nos Acordos de Acionistas e sua Eficácia Executiva. In Revista de Direito Mercantil, Industrial, Econômico e Financeiro. $\mathrm{n}^{\circ}$ 127. São Paulo: Malheiros, 2002, p. 63.

SADDI, Jairo. Vinculação do voto dos administradores indicados pelo acordo de voto. In Estudos em Homenagem a Modesto Carvalhosa. São Paulo: Saraiva, 2012. pp. 656-667.

SALLES, Denise Chachamovitz Leão de. Acordo de Acionistas: um Panorama Evolutivo. In CASTRO, Rodrigo R. Monteiro de; ARAGÃO, Leandro Santos. Sociedade Anônima: 30 anos da Lei 6.404/76. São Paulo: Quartier Latin, 2007, pp. 479-508

SALOMÃO FILHO, Calixto. O Novo Direito Societário. $4^{\mathrm{a}}$ ed. São Paulo: Malheiros, 2011.

SZTAJN, Rachel. Acordo de Acionistas. In SADDI, Jairo (Org.). Fusões e Aquisições: Aspectos Jurídicos e Econômicos. São Paulo: IOB, 2002. pp. 273-294.

SILVA, Alexandre Couto. Responsabilidade dos Administradores de S.A. - Business Judgement Rule. Rio de Janeiro: Elsevier, 2007.

SPINOLA E CASTRO, Eduardo. Acordo de Acionistas Celebrado no âmbito de Sociedade Holding, Joint Venture ou Sociedade de Comando de Grupo de Sociedades - Sua Necessária Extensão às Sociedades Controladas ou Operacionais. In CASTRO, Rodrigo R. Monteiro de; MOURA AZEVEDO, Luis André N. (Coord.). Poder de Controle e 
Outros Temas de Direito Societário e Mercado de Capitais. São Paulo: Quartier Latin, 2010, pp. 421-434.

SPINELLI, Luis Felipe. Conflito de Interesses na Administração da Sociedade Anônima. São Paulo: Malheiros, 2012.

STIGLER. George J. The Theory of Economic Regulation. The University of Chicago.

TEIXEIRA, Egberto Lacerda; GUERREIRO, José Alexandre Tavares. Das sociedades anônimas no direito brasileiro, v. 2. São Paulo: Buchatsky, 1979.

THOMAS, Reece and RYAN C.L. The Law and Practice of Shareholders Agreements. London, Lexis Nexis. Third Edition, 1991.

TOLEDO, Paulo Fernando Campos Salles de. Modificações Introduzidas na lei das Sociedades por Ações, quanto à disciplina da Administração das Companhias. In: LOBO, Jorge (Coord.). Reforma da Lei das Sociedades Anônimas - Inovações e Questões Controvertidas da Lei $n^{\circ}$ 10.303, de 31.10.2001. Rio de Janeiro: Forense, 2002.

Comentários à Lei de Recuperação de Empresas e Falência (obra coletiva). $4^{\text {a }}$ ed. São Paulo: Saraiva, 2010.

TORNOVSKY, Miguel. Acordos de Acionistas sobre o Exercício do Poder de Controle. Análise das Principais Alterações Introduzidas ao art. 118 da Lei das S.A. pela Lei 10.303/2001. In Revista de Direito Mercantil, Industrial, Econômico e Financeiro. $\mathrm{n}^{\mathrm{o}} 127$. São Paulo: Malheiros, 2002, p. 100.

URTIAGA, María Gutierrez; SAEZ, Maribel. Deconstructing Independent Directors. Working Paper No. 186/2012. January 2012, p. 14. Disponível in $<\mathrm{http}: / /$ ssrn.com/abstract=1986842>. Último acesso em 18.01.2014

VERÇOSA, Haroldo Malheiros Duclerc. Curso de direito comercial. v. 1. 2 ed. São Paulo: Malheiros, 2008. 
. Curso de direito comercial. v. 2. $2^{\text {a }}$ ed. São Paulo: Malheiros, 2010.

. Curso de direito comercial. v. 3. $2^{\mathrm{a}}$ ed. São Paulo: Malheiros, 2011.

. Curso de direito comercial. v. 4. $1^{\text {a }}$ ed. São Paulo: Malheiros, 2011.

Contratos Mercantis e a Teoria geral dos Contratos. O Código Civil

de 2002 e a Crise do Contrato. São Paulo: Quartier Latin, 2010.

Atividade mercantil. Ato de comércio. Mercancia. Matério de comércio. Comerciante. In Revista de Direito Mercantil, Industrial, Econômico e Financeiro. n $^{\circ}$ 47. São Paulo: Malheiros, 1982, p. 29.

; SZTAJN, Rachel. A incompletude do contrato de sociedade. In

Revista de Direito Mercantil, Industrial, Econômico e Financeiro. $n^{\circ}$ 131. São Paulo: Malheiros, 2003. p. 7.

;

Contrato de Sociedade: completamento. In

Estudos em Homenagem a Modesto Carvalhosa. São Paulo: Saraiva, 2012. pp. 624-639.

VERGUEIRO, Carlos Eduardo. Acordo de Acionistas e a Governança das Companhias. São Paulo: Quartier Latin, 2010.

VIDIGAL, Luiz Eulálio Bueno. Da Execução Direta de Obrigação de Prestar Declaração de Vontade. In: Direito Processual Civil. São Paulo: Saraiva, 1940.

VILLELA, João Baptista. In: Controle Acionário: Corpus et Anima. São Paulo: Malheiros, separata, 2010.

VIVANTE, Cesare. Instituições de Direito Comercial. Sorocaba: Minelli, 2007.

VON ADAMEK, Marcelo Vieira. Responsabilidade civil dos administradores de S/A e as ações correlatas. São Paulo: Saraiva, 2009. 
WALD, Alexandre de M. Acordo de Acionistas e Interesses Sociais. In: Arnoldo Wald e Rodrigo Garcia da Fonseca (Coord.) A Empresa no Terceiro Milênio: Aspectos Jurídicos. São Paulo: Juarez de Oliveira, 2005, p. 91.

WALD, Arnoldo. Estudos e Pareceres de Direito Comercial. v. II. São Paulo: Revista dos Tribunais, 1979.

A Evolução do Regime Legal do Conselho de Administração, os Acordos de Acionistas e os Impedimentos dos Conselheiros decorrentes de Conflito de Interesses. In Revista de Direito Mercantil, Industrial, Econômico e Financeiro. $n^{\circ} 11$. São Paulo: Malheiros, p. 16.

WIEDEMANN, Herbert. Excerto de Direito Societário I - Fundamentos, de Herbert Wiedemann. Tradução de Erasmo Valadão A. e N. França. In Revista de Direito Mercantil, Industrial, Econômico e Financeiro. n ${ }^{\circ}$ 143. São Paulo: Malheiros, pp. 66-75.

ZAITZ, Daniela. Responsabilidade Civil dos Administradores de Sociedades Por Ações e Por Quotas de Responsabilidade Limitada. RT 740, junho de 1997.

ZANINI, Carlos Klein. A Doutrina dos Fiduciary Duties no Direito Norte-Americano e a Tutela das Sociedades e Acionistas Minoritários frente aos Administradores das Sociedades Anônimas. In Revista de Direito Mercantil, Industrial, Econômico e Financeiro. no 109. São Paulo: Malheiros, pp. 137-149. 